UNIVERSIDADE DE SÃO PAULO

INSTITUTO DE GEOCIÊNCIAS

\title{
INTERAÇÃO DE GASOLINA, BENZENO, TOLUENO E XILENOS COM ARGILOMINERAIS ESMECTÍTICOS DA FORMAÇÃO RESENDE, BACIA DE SÃO PAULO
}

Nicolas do Nascimento Varzacacou

Orientadora: Profa. Dra. Lucy Gomes Sant'Anna

\section{DISSERTAÇÃO DE MESTRADO}

Programa de Pós-Graduação em Geoquímica e Geotectônica

São Paulo

2009 
Ficha catalográfica preparada pelo Serviço de Biblioteca e Documentação do Instituto de Geociências da Universidade de São Paulo

Varzacacou, Nicolas do Nascimento

Interação de gasolina, benzeno, tolueno e xilenos com argilominerais esmectíticos da Formação Resende, Bacia de São Paulo- São Paulo, 2009.

79 f. : il.

Dissertação (Mestrado) : IGc/USP

Orient.: Sant'Anna, Lucy Gomes

1. Gasolina 2. Argila 3. Adsorção 4. Absorção

I. Título 
À Carol e nosso bebê. 
Dados da CETESB revelam que a comercialização de derivados do petróleo na Cidade de São Paulo, em especial a gasolina, tem gerado um número significativo de casos de vazamento de combustíveis, causados pela falta de manutenção de equipamentos, deterioração de tanques e tubulações, e falhas operacionais decorrentes do despreparo dos profissionais que atuam nesses estabelecimentos.

A área urbana da Cidade de São Paulo está, em grande parte, edificada sobre os depósitos sedimentares de idade cenozóica da Bacia de São Paulo, onde a Formação Resende apresenta distribuição generalizada e compreende mais de $80 \%$ do preenchimento sedimentar. Argilominerais esmectíticos predominam na fração fina dos sedimentos da Formação Resende e a possível interação deles com hidrocarbonetos foi o objeto de investigação dessa dissertação. Nesse sentido, o presente trabalho teve por objetivo o estudo laboratorial da interação, por meio de sorção e desorção, de hidrocarbonetos encontrados comumente, como gasolina comercial, benzeno, tolueno e xilenos, com argilominerais esmectíticos da Formação Resende, no contexto da zona vadosa, na Bacia de São Paulo. Para tanto, três amostras argilosas da Formação Resende foram coletadas na zona leste da Cidade de São Paulo, tendo sido efetuada sua caracterização granulométrica, mineralógica (via DRX) e química (análise de $\mathrm{CNH}$ ).

Em testes de inchamento com gasolina e orgânicos puros, nenhuma das amostras apresentou absorção dos compostos.

Os testes de adsorção e desorção procuraram caracterizar a interação dos hidrocarbonetos com a rocha total, fração silte e fração argila dos sedimentos, variando-se o tempo de exposição (30 minutos a 32 dias) das amostras aos contaminantes. Os resultados obtidos permitiram reconhecer que a adsorção é o mecanismo de sorbância predominante.

A variação das concentrações ao longo do tempo evidenciou que a interação amostra/contaminante é dinâmica ao longo do tempo de contato, havendo momentos distintos de sorbância, com variação significativa e bem representada dos teores adsorvidos, e que essas fases ocorrem independentemente da granulometria ou mineralogia das amostras, sendo:

- os sedimentos argilosos adsorvem, na média, as mesmas ordens de grandeza de cada contaminante, o que é devido a sua homogeneidade granulométrica e mineralógica em pequena escala;

- dentro da ordem de grandeza de adsorção de cada contaminante, as diferenças composicionais (granulométricas e mineralógicas) entre as amostras de sedimentos argilosos alteram os teores dos compostos em função da proporção de argila na rocha total, de forma que quanto mais argiloso mais contaminante será adsorvido, e do tipo de argilomineral predominante na fração argila, sendo a maior proporção de esmectita um fator favorável. 


\section{Abstract}

Data from the Environmental Agency of São Paulo State (Company of Environmental Sanitation Technology - CETESB) reveal that the commercialization of petroleum products in the city, especially gasoline, has generated a high number of fuel leakages and contaminated areas.

The urban area of São Paulo city is underlain by the Cenozoic sedimentary deposits of the São Paulo Basin. In this basin, smectite-rich mudstone of the Resende Formation is widely distributed and comprises over $80 \%$ of the sedimentary filling.

The aim of this study was to investigate the interaction of smectite-rich mudstone of the Resende Formation with hydrocarbons in the São Paulo Basin. The sorption and desorption of common hydrocarbons, such as gasoline, benzene, toluene and xylene, by the smectitic clay minerals, in the context of vadose zone, were investigated in laboratory.

Three representative subsurface samples of mudstone were collected in the east part of São Paulo city and characterized by granulometry, X-ray analysis and CHN determination. Swelling test with gasoline and pure organic compounds does not promote absorption in the three studied samples.

Adsorption and desorption tests were employed to characterize the interaction between the hydrocarbons and the whole-rock, silt- and clay-fractions of the mudstone in different time intervals of contact (30 minutes to 32 days). The results revealed the adsorption as the main interaction mechanism.

Variations in concentration of contaminants in different time intervals of contact indicated a dynamic interaction between sample and hydrocarbons, existing phases with distinct amounts of organics adsorbed (or retained after desorption). Theses phases are controlled by the time of contact and are independent of samples granulometry and mineralogy, and contaminant type.

The three mudstone samples adsorb about the same amount of each contaminant, which is due to their overall granulometric and mineralogic homogeneity. Nevertheless, minor and local changes in sample composition (granulometry and mineralogy) cause a small scale variation in the amounts of each contaminant adsorbed as a result either of clay proportion in the whole-rock and of the predominant clay mineral in the clay fraction. 


\section{Agradecimentos}

A minha companheira, e meu grande amor Carol, e nosso bebê que vêm por ai, por me proporcionar essa oportunidade, e sempre me apoiar durante o andamento desse grande desafio na minha vida. Sem teu apoio esse projeto não teria se realizado.

À Fundação de Amparo à Pesquisa do Estado de São Paulo - FAPESP agradeço o apoio na forma de auxílio à pesquisa (processo 2008/52875-2) concedido à orientadora.

Ao Conselho Nacional de Desenvolvimento Científico e Tecnológico - CNPq agradeço a concessão de bolsa de estudo.

À Companhia do Metropolitano de São Paulo - Metrô pela permissão para visitas às obras de extensão da Linha 2 - Verde e coleta de amostras.

À Lucy, orientadora dedicada, que sempre me apoiou na medida certa, meus mais sinceros agradecimentos.

À Associação Brasileira de Cimento Portland pelo apoio na realização dos ensaios de sorção e desorção e realização das análises de CHN e difração de raios X. Ao grande amigo Marcelo Picho por toda a enorme ajuda, fico eternamente grato, e à equipe da ABCP, Yushiro Kihara, e Arnaldo Battagin, agradeço por permitirem a utilização da infraestrutura, a Patrícia, Janaína e o Antonio agradeço por me proporcionarem todo o apoio e ótimos momentos no laboratório para finalização dos ensaios.

Aos laboratórios de Sedimentologia, Difração de Raios X e Preparação de Amostras do IGc-USP, agradeço pelo apoio nos trabalhos de preparação e caracterização dos sedimentos.

Ao IGc-USP, à Comissão de Pós-Graduação e à Coordenação do Programa de PósGraduação em Geoquímica e Geotectônica, meus agradecimentos pelo apoio institucional.

A minha família, Ângela, Adélia, e Naiadi.

E a todos que, de alguma forma colaboraram para a execução desse trabalho, meus agradecimentos. 
Índice

1 Introdução e justificativas.......................................................................... 1

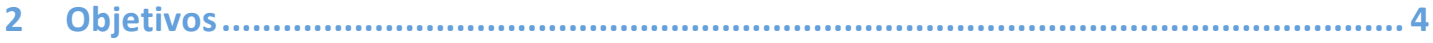

3 Levantamento bibliográfico .............................................................4 4

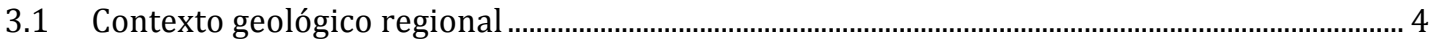

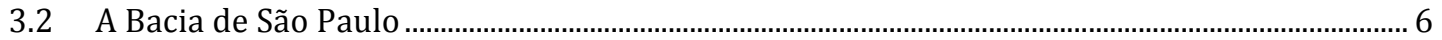

3.3 Formação Resende ........................................................................................................................... 8

3.4 Definição, estrutura e classificação dos argilominerais ................................................................. 9

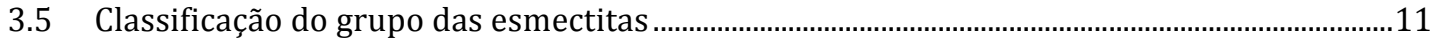

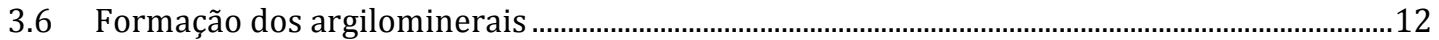

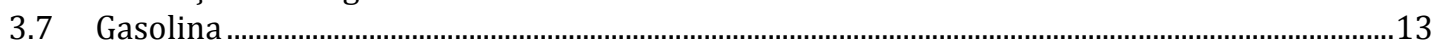

3.8 Interação de argilominerais esmectíticos com hidrocarbonetos ................................................16

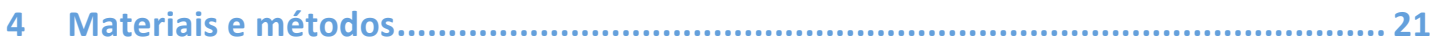

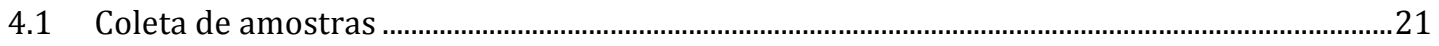

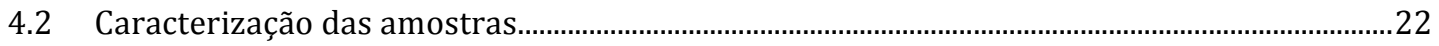

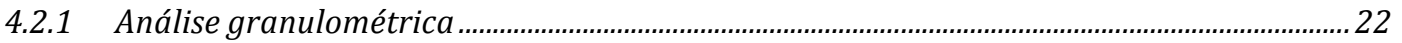

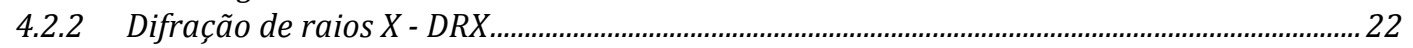

4.2.3 Microscopia eletrônica de varredura - MEV ................................................................................26

4.2.4 Análise elementar de carbono, hidrogênio e nitrogênio - CHN..............................................26

4.3 Ensaios de sorção e desorção .......................................................................................................26

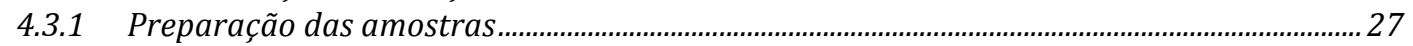

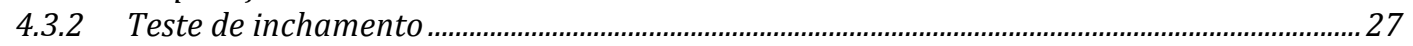

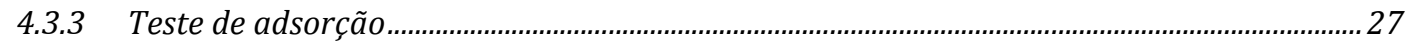

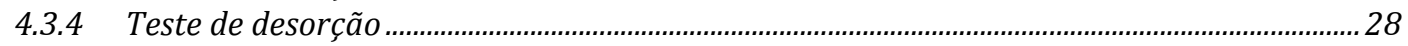

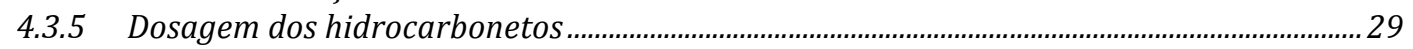

5 Resultados da caracterização das a mostras .................................................. 29

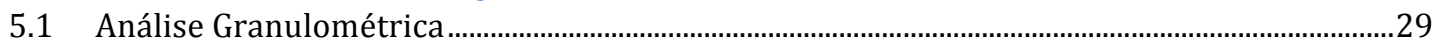

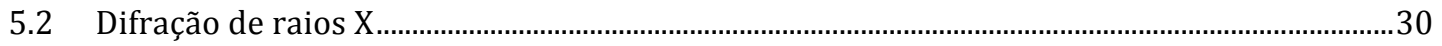

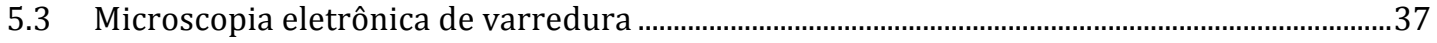

5.4 Análise elementar de carbono, hidrogênio e nitrogênio..............................................................37

6 Resultados dos ensaios de sorção e desorção ............................................... 40

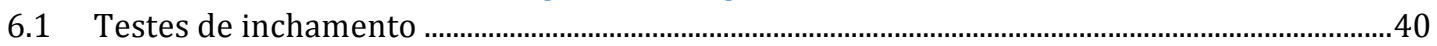

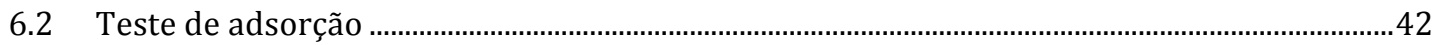

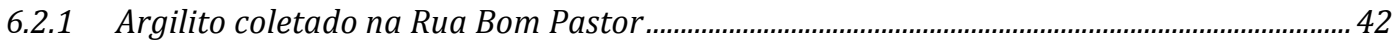

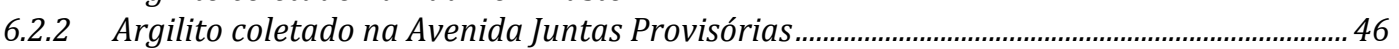

6.2.3 Argilito coletado na Rua Cavour ............................................................................................50

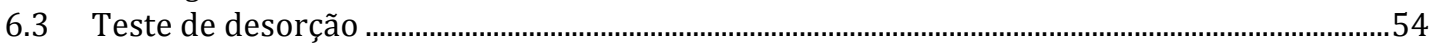

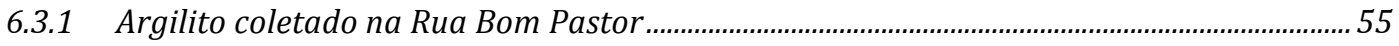

6.3.2 Argilito coletado na Avenida Juntas Provisórias ..................................................................57

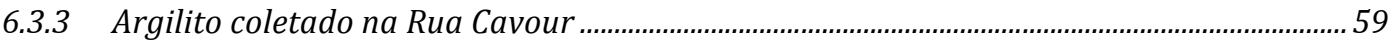

7 Discussão dos resultados ................................................................61

7.1 Características físico-químicas dos sedimentos ......................................................................61

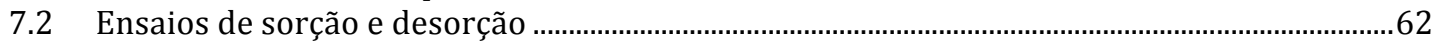

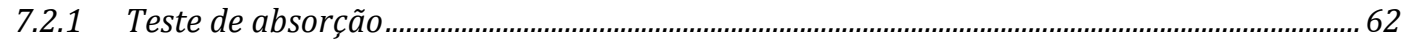

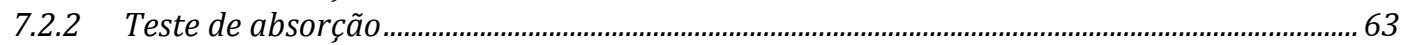

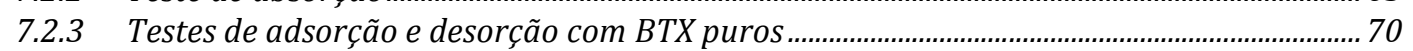

8 Conclusões ......................................................................... 73

9 Referências Bibliográficas .......................................................................... 74

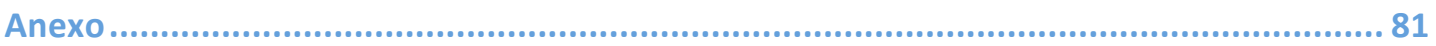


Figura 1 - Evolução das áreas contaminadas identificadas no Estado de São Paulo (CETESB, 2008)..

Figura 2 - (a) Representação (em porcentagem) das áreas contaminadas no Estado de São Paulo, relacionadas a postos de gasolina e a outras atividades. (b) Representação (em porcentagem) de postos de combustíveis declarados áreas contaminadas na Cidade de São Paulo e no Estado de São Paulo. (c) Representação (em porcentagem) de postos de combustíveis declarados áreas contaminadas na RMSP (incluindo Cidade de São Paulo) e Vale do Rio Paraíba do Sul, em comparação com o restante do Estado de São Paulo. Fonte dos dados: CETESB (2008).

Figura 3 - Contexto geológico regional do Rift Continental do Sudeste do Brasil (RCSB) (Riccomini et al. 2004): 1) embasamento pré-cambriano; 2) rochas sedimentares paleozóicas da Bacia do Paraná; 3) rochas vulcânicas eocretáceas da Formação Serra Geral; 4) rochas relacionadas ao magmatismo alcalino mesozóico-cenozóico; 5) bacias cenozóicas do rift (1- Bacia de Itaboraí, 2- Graben de Barra de São João, 3- Bacia do Macacu, 4- Bacia de Volta Redonda, 5- Bacia de Resende, 6- Bacia de Taubaté, 7- Bacia de São Paulo, 8- Graben de Sete Barras, 9- Formação Pariqüera-Açu, 10- Formação Alexandra e Graben de Guaraqueçaba, 11- Bacia de Curitiba, 12- Graben de Cananéia); 6) zonas de cisalhamento pré-cambrianas, em parte reativadas durante o Mesozóico e Cenozóico.

Figura 4 - Mapa geológico da Bacia de São Paulo e porção sudoeste da Bacia de Taubaté (Riccomini et al. 2004): 1) embasamento pré-cambriano; 2) Formação Resende (sistema de leques aluviais proximais); 3) Formação Resende (sistema de leques aluviais medianos a distais associados a planície aluvial de rios entrelaçados); 4) Formação Tremembé; 5) Formação São Paulo; 6) Formação Itaquaquecetuba; 7) sedimentos quaternários; 8) falhas cenozóicas, em parte reativadas do embasamento pré-cambriano. 0 traçado contínuo de cor laranja representa os limites do Município de São Paulo.

Figura 5 - Quadro litoestratigráfico da Bacia de São Paulo (modificado de Riccomini et al. 2004). Letras: $\mathrm{p}$ - leques aluviais proximais; $\mathrm{m}-\mathrm{d}$ - leques aluviais medianos a distais associados à planície aluvial de rios entrelaçados; ca - depósitos colúvio-aluviais; a - depósitos aluviais. ...... 8

Figura 6 - Poliedro tridimensional mostrando a estrutura idealizada de um argilomineral 2:1 (adaptado de Moore \& Reynolds 1997). Legenda: esferas azuis grandes representam hidroxilas; esferas pretas grandes são oxigênios; esferas pretas pequenas são cátions nas cavidades tetraédricas; esferas vermelhas grandes são cátions nas cavidades octaédricas.......12

Figura 7 - Forma dos argilominerais (Velde, 1992) .......................................................................................16

Figura 8 - Ilustração de mecanismos de sorção (Parker \& Rae 1998) ...........................................................17

Figura 9 - Interação entre a superfície carregada negativamente dos argilominerais e íons em solução (Parker \& Rae 1998).

Figura 10- Tempos de interação determinam forma de sorção (Neumann 2000)...

Figura 11- Mudança no espaçamento interlamelar da esmectita com a incorporação de moléculas absorvidas. A maior hidratação implica em um aumento do espaçamento (Velde 1995)

Figura 12- Moléculas lineares e não lineares incorporadas nos argilominerais (Sharmasarkar 2000)

Figura 13 - Traçado da Linha 2-Verde (Ana Rosa - Vila Prudente) do Metrô (Metrô 2009)...............21

Figura 14- (A) Mapa com a localização da região amostrada na Bacia de São Paulo, na zona leste da Cidade de São Paulo. (B) Detalhe do mapa da figura anterior, com a localização das frentes de obras amostradas na Rua Bom Pastor, Avenida Juntas Provisórias e Rua Cavour. (C) Mapa do local de acesso à obra subterrânea na Rua Bom Pastor. (D) Foto do túnel subterrâneo escavado na Formação Resende, entre a Rua Bom Pastor e a Av. Juntas Provisórias. (E) Foto de frente de escavação na Formação Resende onde foi efetuada coleta de amostra. (F) Mapa do local de acesso à obra subterrânea na Av. Juntas Provisórias. (G) Foto do poço de acesso ao túnel subterrâneo sob a Av. Juntas Provisórias. (H) Mapa do local de acesso à obra subterrânea na Rua Cavour. (I) Foto de poço de emergência na futura estação Vila Prudente, nas proximidades da Rua Cavour, onde aflora a Formação Resende 
na base. (J) Foto do poço de serviços na Rua Cavour, onde aflora a Formação Resende na base e foi coletada amostra.

Figura 15 - Perfis geológicos da Formação Resende, com indicação do local de coleta de amostras.

Figura 16 - (A) Foto ilustrando frente de escavação na Formação Resende, onde foi efetuada coleta de amostra. (B) Detalhe de contato de camada de lamito e lente arenosa. (C) Detalhe de camada de lamito cinza amostrada.

Figura 17 - Roteiro dos ensaios de adsorção e desorção.

Figura 18 - Distribuições granulométricas das amostras da Formação Resende coletadas em frentes de obra na Rua Bom Pastor (BP), na Av. Juntas Provisória (JP) e na Rua Cavour (CA).

Figura 19 - Diagrama de Folk (1974), com a classificação de rochas sedimentares contendo misturas de areia e lama (argila e silte) e sem cascalho. As esferas coloridas representam a distribuição granulométrica das amostras analisadas (vermelho - Bom Pastor, azul - Juntas Provisórias, verde - Cavour). Legenda: A - arenito, Aag - arenito argiloso, Al - arenito lamoso, As - arenito siltoso, Aga - argilito arenoso, La - lamito arenoso, Sa - siltito arenoso, $\mathrm{Ag}$ - argilito, L - lamito, $\mathrm{S}$ - siltito.

Figura 20 - Difratogramas de raios X do argilito coletado na Rua Bom Pastor. Legenda: gráfico preto - rocha total; gráfico azul - fração silte natural (seca ao ar); gráfico vermelho - fração argila natural (seca ao ar).

Figura 21- Difratogramas de raios X da fração silte do argilito coletado na Rua Bom Pastor. Legenda: gráfico preto - amostra natural (seca ao ar); gráfico azul - amostra solvatada; gráfico vermelho - amostra aquecida.

Figura 22- Difratogramas de raios X da fração argila do argilito coletado na Rua Bom Pastor. Legenda: gráfico preto - amostra natural; gráfico azul - amostra solvatada; gráfico vermelho - amostra aquecida..

Figura 23 - Difratogramas de raios X do argilito coletado na Av. Juntas Provisórias. Legenda: gráfico preto - rocha total; gráfico azul - fração silte natural; gráfico vermelho - fração argila natural.

Figura 24 - Difratogramas de raios X da fração silte do argilito coletado na Av. Juntas Provisórias. Legenda: gráfico preto - amostra natural; gráfico azul - amostra solvatada; gráfico vermelho - amostra aquecida.

Figura 25 - Difratogramas de raios X da fração argila do argilito coletado na Av. Juntas Provisórias. Legenda: gráfico preto - amostra natural; gráfico azul - amostra solvatada; gráfico vermelho - amostra aquecida.

Figura 26- Difratogramas de raios X do argilito coletado na Rua Cavour. Legenda: gráfico preto rocha total; gráfico azul - fração silte natural; gráfico vermelho - fração argila natural.............34

Figura 27 - Difratogramas de raios X da fração silte do argilito coletado na Rua Cavour. Legenda: gráfico preto - amostra natural; gráfico azul - amostra solvatada; gráfico vermelho amostra aquecida.

Figura 28 - Difratogramas de raios X da fração argila do argilito coletado na Rua Cavour. Legenda: gráfico preto - amostra natural; gráfico azul - amostra solvatada; gráfico vermelho - amostra aquecida..

Figura 29 - Comparação entre os difratogramas de raios X de rocha total (A), fração silte (B) e fração argila (C) das amostras de argilito da Formação Resende. Legenda: gráfico preto amostra coletada na Rua Bom Pastor; gráfico vermelho - amostra coletada na Av. Juntas Provisórias; gráfico azul - amostra coletada na Rua Cavour.

Figura 30- Imagens de MEV (sinal de elétrons secundários SE) do argilito coletado na Rua Bom Pastor. (A) Aspecto geral mostrando os grãos detríticos de quartzo (Q) e placa de mica (M), com granulação silte, imersos na matriz argilosa maciça. (B) Detalhe da matriz argilosa composta por placas arredondadas de argilomineral (seta preta). (C) Visão de lepisferas de sílica preenchendo a porosidade esparsa (seta preta). (D) Detalhe das lepisferas de sílica preenchendo paredes de cavidade ocupada anteriormente por grão detrítico (parte central da imagem) 
Figura 31- Imagens de MEV (SE) do argilito coletado na Av. Juntas Provisórias. (A) Visão geral do argilito mostrando sua estrutura maciça. (B) Detalhe de grão de quartzo detrítico imerso na matriz argilosa. (C) Detalhe do empacotamento de argilominerais na matriz do argilito. (D) Detalhe mostrando as bordas corroídas e irregulares (vide seta preta) das placas de argilominerais constituintes da matriz do argilito.

Figura 32 - Imagens de MEV (SE) do argilito coletado na Rua Cavour. (A) Visão geral do argilito. (B) Detalhe das placas arredondadas (vide seta preta) de argilominerais constituintes da matriz do argilito.

Figura 33 - Difratogramas de raios X de rocha total dos argilitos da Formação Resende analisados pelo teste de inchamento. (A) Amostra BP, contaminada com gasolina, (B) Amostra BP, contaminada com tolueno, (C) Amostra BP, contaminada com xileno, (D) Amostra JP, contaminada com gasolina, (E) Amostra JP, contaminada com tolueno, (F) Amostra JP, contaminada com xileno, (G) Amostra CA, contaminada com tolueno...

Figura 34 - Gráfico da variação da concentração de benzeno (A), tolueno (B), etilbenzeno (C), mp-xilenos (D) e o-xileno (E) em função do tempo de contato entre GASOLINA e a amostra BP (Legenda: azul - rocha total, vermelho - fração silte, verde - fração argila).

Figura 35 - Gráfico logarítmico da variação da concentração de benzeno (A), tolueno (B), etilbenzeno (C), mp-xilenos (D) e o-xileno (E) em função do tempo de contato entre GASOLINA e a amostra BP (Legenda: azul - rocha total, vermelho - fração silte, verde fração argila).

Figura 36 - Gráfico da variação da concentração de benzeno (A), tolueno (B) e mp-xilenos (C) em função do tempo de contato entre o CONTAMINANTE PURO e a amostra BP (Legenda: azul - rocha total, vermelho - fração silte, verde - fração argila). .

Figura 37 - Gráfico da variação da concentração de benzeno (A), tolueno (B), etilbenzeno (C), mp-xilenos (D) e o-xileno (D) em função do tempo de contato entre GASOLINA e a amostra JP (Legenda: azul - rocha total, vermelho - fração silte, verde - fração argila).

Figura 38 - Gráfico logarítmico da variação da concentração de benzeno (A), tolueno (B), etilbenzeno (C), mp-xilenos (D) e o-xileno (E) em função do tempo de contato entre GASOLINA e a amostra JP (Legenda: azul - rocha total, vermelho - fração silte, verde fração argila).

Figura 39 - Gráfico da variação da concentração de benzeno (A), tolueno (B) e mp-xilenos (C) em função do tempo de contato entre o CONTAMINANTE PURO e a amostra JP (Legenda: azul rocha total, vermelho - fração silte, verde - fração argila). .

Figura 40 - Gráfico da variação da concentração de benzeno (A), tolueno (B), etilbenzeno (C), mp-xilenos (D) e o-xileno (D) em função do tempo de contato entre GASOLINA e a amostra CA (Legenda: azul - rocha total, vermelho - fração silte, verde - fração argila).

Figura 41 - Gráfico logarítmico da variação da concentração de benzeno (A), tolueno (B), etilbenzeno (C), mp-xilenos (D) e o-xileno (E) em função do tempo de contato entre GASOLINA e a amostra CA (Legenda: azul - rocha total, vermelho - fração silte, verde fração argila).

Figura 42 - Gráfico da variação da concentração de benzeno (A), tolueno (B) e mp-xilenos (C) em função do tempo de contato entre o CONTAMINANTE PURO e a amostra CA (Legenda: azul - rocha total, vermelho - fração silte, verde - fração argila).

Figura 43- Gráfico da variação da concentração de benzeno (A), tolueno (B), etilbenzeno (C), mp-xilenos (D) e o-xileno (D) em função do tempo de desorção de GASOLINA na amostra BP (Legenda: azul - rocha total, vermelho - fração silte, verde - fração argila)....

Figura 44 - Gráfico da variação da concentração de benzeno (A), tolueno (B) e mp-xilenos (C) em função do tempo de desorção do CONTAMINANTE PURO na amostra BP (Legenda: azul rocha total, vermelho - fração silte, verde - fração argila)...

Figura 45 - Gráfico da variação da concentração de benzeno (A), tolueno (B), etilbenzeno (C), mp-xilenos (D) e o-xileno (D) em função do tempo de desorção de gasolina na amostra JP (Legenda: azul - rocha total, vermelho - fração silte, verde - fração argila).

Figura 46 - Gráfico da variação da concentração de benzeno (A), tolueno (B) e mp-xilenos (C) em função do tempo de desorção do CONTAMINANTE PURO na amostra JP (Legenda: azul rocha total, vermelho - fração silte, verde - fração argila). . 
Figura 47 - Gráfico da variação da concentração de benzeno (A), tolueno (B), etilbenzeno (C), mp-xilenos (D) e o-xileno (D) em função do tempo de desorção de GASOLINA e a amostra CA (Legenda: azul - rocha total, vermelho - fração silte, verde - fração argila).

Figura 48 - Gráfico da variação da concentração de benzeno (A), tolueno (B) e mp-xilenos (C) em função do tempo de desorção do CONTAMINANTE PURO na amostra CA (Legenda: azul rocha total, vermelho - fração silte, verde - fração argila)

Figura 49 - Fatores considerados na avaliação integrada dos dados químicos.

Figura 50 - Gráfico dos teores médios de BTEX obtidos a partir do teste de adsorção com a rocha total e frações finas (silte e argila) dos argilitos da Formação Resende contaminados por gasolina (Legenda: azul - rocha total, vermelho - fração silte, verde - fração argila).

Figura 51 - Gráfico das médias dos teores de BTEX obtidos a partir do teste de adsorção com a rocha total e frações finas (silte e argila) dos argilitos da Formação Resende contaminados por gasolina (Legenda: azul - rocha total, vermelho - fração silte, verde - fração argila).

Figura 52 - Gráfico dos teores médios de BTEX obtidos a partir do teste de desorção com a rocha total e frações finas (silte e argila) dos argilitos da Formação Resende contaminados por gasolina (Legenda: azul - rocha total, vermelho - fração silte, verde - fração argila).

Figura 53 - Gráfico das médias dos teores de BTEX obtidos a partir do teste de desorção com a rocha total e frações finas (silte e argila) dos argilitos da Formação Resende contaminados por gasolina (Legenda: BP - argilito coletado na Rua Bom Pastor, JP - argilito coletado na Av. Juntas Provisórias, CA - argilito coletado na Rua Cavour). 
Tabela 1 - Classificação dos filossilicatos, com ênfase nos argilominerais (adaptado de Moore \& Reynolds 1997).

Tabela 2 - Ocupação dos sítios octaédricos (adaptado de Moore \& Reynolds 1997).............................11

Tabela 3 - Frações dos compostos BTX nas gasolinas brasileiras (Corseuil \& Fernandes 1999). ......14

Tabela 4 - Características físico-químicas das gasolinas Tipo A e Tipo C, Benzeno, Tolueno,

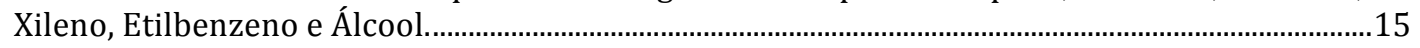

Tabela 5 - Resultados de testes de adsorção com bentonita (Pereira et al. 2005)..................................19

Tabela 6 - Resultados das análises de CHN (\% em massa). .........................................................................37

Tabela 7 - Teores médios de BTEX (mg/kg) obtidos a partir do teste de adsorção com gasolina. ....65

Tabela 8 - Teores médios de BTEX (mg/kg) obtidos a partir do teste de desorção com gasolina. ....68

Tabela 9 - Diferença (em porcentagem) entre os teores médios de BTEX medidos nos testes de adsorção e desorção com gasolina.

Tabela 10 - Médias dos teores de BTEX (mg/kg) nas amostras contaminadas com compostos orgânicos (BTX) puros, para os ensaios de adsorção.

Tabela 11 - Médias dos teores de BTX (mg/kg) nas amostras com contaminantes puros, para ensaios de desorção..

Tabela 12 - Diferença (em porcentagem) entre os teores médios de BTX medidos nos testes de sorção e desorção com compostos puros.

Tabela 13 - Concentrações de BTEX (em mg/Kg) obtidas no ensaio de sorção de gasolina pelo argilito coletado na Rua Bom Pastor (amostra BP), na forma de rocha total (T), fração silte (S) e fração argila (A).

Tabela 14 - Concentrações de benzeno (em $\mathrm{mg} / \mathrm{Kg}$ ) obtidas no ensaio de sorção do contaminante puro pelo argilito coletado na Rua Bom Pastor (amostra BP), na forma de rocha total (T), fração silte (S) e fração argila (A).

Tabela 15 - Concentrações de tolueno (em mg/Kg) obtidas no ensaio de sorção do contaminante puro pelo argilito coletado na Rua Bom Pastor (amostra BP), na forma de rocha total (T), fração silte (S) e fração argila (A).

Tabela 16 - Concentrações de xilenos (em mg/Kg) obtidas no ensaio de sorção do contaminante puro pelo argilito coletado na Rua Bom Pastor (amostra BP), na forma de rocha total (T), fração silte (S) e fração argila (A).

Tabela 17 - Concentrações de BTEX (em mg/Kg) obtidas no ensaio de sorção de gasolina pelo argilito coletado na Av. Juntas Provisórias (amostra JP), na forma de rocha total (T), fração silte (S) e fração argila (A).

Tabela 18 - Concentrações de benzeno (em $\mathrm{mg} / \mathrm{Kg}$ ) obtidas no ensaio de sorção do contaminante puro pelo argilito coletado na Av. Juntas Provisórias (amostra JP), na forma de rocha total (T), fração silte (S) e fração argila (A)..

Tabela 19 - Concentrações de tolueno (em mg/Kg) obtidas no ensaio de sorção do contaminante puro pelo argilito coletado na Av. Juntas Provisórias (amostra JP), na forma de rocha total $(\mathrm{T})$, fração silte $(\mathrm{S})$ e fração $\operatorname{argila}(\mathrm{A})$.

Tabela 20 - Concentrações de xilenos (em mg/Kg) obtidas no ensaio de sorção do contaminante puro pelo argilito coletado na Av. Juntas Provisórias (amostra JP), na forma de rocha total (T), fração silte (S) e fração argila (A).

Tabela 21 - Concentrações de BTEX (em mg/Kg) obtidas no ensaio de sorção de gasolina pelo argilito coletado na Rua Cavour (amostra CA), na forma de rocha total (T), fração silte (S) e fração argila (A).

Tabela 22 - Concentrações de benzeno (em $\mathrm{mg} / \mathrm{Kg}$ ) obtidas no ensaio de sorção do contaminante puro pelo argilito coletado na Rua Cavour (amostra CA), na forma de rocha total $(\mathrm{T})$, fração silte $(\mathrm{S})$ e fração argila $(\mathrm{A})$. 
Tabela 23 - Concentrações de tolueno (em mg/Kg) obtidas no ensaio de sorção do contaminante puro pelo argilito coletado na Rua Cavour (amostra CA), na forma de rocha total (T), fração silte (S) e fração argila (A)...

Tabela 24 -Concentrações de xilenos (em mg/Kg) obtidas no ensaio de sorção do contaminante puro pelo argilito coletado na Rua Cavour (amostra CA), na forma de rocha total (T), fração silte (S) e fração argila (A).

Tabela 25 - Concentrações de BTEX (em mg/Kg) obtidas no ensaio de desorção de gasolina pelo argilito coletado na Rua Bom Pastor (amostra BP), na forma de rocha total (T), fração silte (S) e fração argila (A).

Tabela 26 - Concentrações de benzeno (em $\mathrm{mg} / \mathrm{Kg}$ ) obtidas no ensaio de desorção do contaminante puro pelo argilito coletado na Rua Bom Pastor (amostra BP), na forma de rocha total (T), fração silte (S) e fração argila (A)..

Tabela 27 - Concentrações de tolueno (em $\mathrm{mg} / \mathrm{Kg}$ ) obtidas no ensaio de desorção do contaminante puro pelo o argilito coletado na Rua Bom Pastor (amostra BP), na forma de rocha total (T), fração silte (S) e fração argila (A)...

Tabela 28 - Concentrações de xilenos (em mg/Kg) obtidas no ensaio de desorção do contaminante puro pelo argilito coletado na Rua Bom Pastor (amostra BP), na forma de rocha total (T), fração silte (S) e fração argila (A)...

Tabela 29 - Concentrações de BTEX (em mg/Kg) obtidas no ensaio de desorção de gasolina pelo argilito coletado na Av. Juntas Provisórias (amostra JP), na forma de rocha total (T), fração silte (S) e fração argila (A).

Tabela 30 - Concentrações de benzeno (em $\mathrm{mg} / \mathrm{Kg}$ ) obtidas no ensaio de desorção do contaminante puro pelo argilito coletado na Av. Juntas Provisórias (amostra JP), na forma de rocha total (T), fração silte (S) e fração argila (A)...

Tabela 31 - Concentrações de tolueno (em mg/Kg) obtidas no ensaio de desorção do contaminante puro pelo argilito coletado na Av. Juntas Provisórias (amostra JP), na forma de rocha total (T), fração silte (S) e fração argila (A)..

Tabela 32 - Concentrações de xilenos (em $\mathrm{mg} / \mathrm{Kg}$ ) obtidas no ensaio de desorção do contaminante puro pelo argilito coletado na Av. Juntas Provisórias (amostra JP), na forma de rocha total (T), fração silte (S) e fração argila (A)...

Tabela 33 - Concentrações de BTEX (em mg/Kg) obtidas no ensaio de desorção de gasolina pelo argilito coletado na Rua Cavour (amostra CA), na forma de rocha total (T), fração silte (S) e fração argila (A).

Tabela 34 - Concentrações de benzeno (em $\mathrm{mg} / \mathrm{Kg}$ ) obtidas no ensaio de desorção do contaminante puro pelo argilito coletado na Rua Cavour (amostra CA), na forma de rocha total (T), fração silte (S) e fração argila (A).

Tabela 35 - Concentrações de tolueno (em $\mathrm{mg} / \mathrm{Kg}$ ) obtidas no ensaio de desorção do contaminante puro pelo argilito coletado na Rua Cavour (amostra CA), na forma de rocha total (T), fração silte (S) e fração argila (A).

Tabela 36 - Concentrações de xilenos (em $\mathrm{mg} / \mathrm{Kg}$ ) obtidas no ensaio de desorção do contaminante puro pelo argilito coletado na Rua Cavour (amostra CA), na forma de rocha total (T), fração silte (S) e fração argila (A). 


\section{Introdução e justificativas}

A sociedade industrial moderna tem seu desenvolvimento em grande parte baseado na utilização de hidrocarbonetos de petróleo como fonte de energia e matéria prima para inúmeros insumos. 0 petróleo é uma mistura complexa de compostos formados por átomos de carbono e hidrogênio, os chamados hidrocarbonetos, contendo proporções menores de compostos oxigenados, nitrogenados, sulfurados e metais pesados (IBP 2009). Durante os processos de exploração, refino, armazenamento, distribuição e uso do petróleo, acontecem acidentes que impactam seriamente o meio ambiente, gerando áreas contaminadas. Uma área contaminada é definida como uma área, local ou terreno onde há comprovadamente contaminação causada pela introdução de quaisquer substância ou resíduo, de forma planejada, acidental ou mesmo natural (CETESB 2008).

A origem das áreas contaminadas está relacionada ao desconhecimento, em épocas passadas, de procedimentos seguros para o manejo de substâncias perigosas, ao desrespeito a procedimentos seguros e à ocorrência de acidentes ou vazamentos durante o desenvolvimento dos processos produtivos, de transporte ou de armazenamento de matérias primas e produtos (CETESB 2008). A existência de uma área contaminada pode causar danos à saúde humana, comprometimento da qualidade dos recursos hídricos, restrições ao uso do solo e prejuízo ao patrimônio público e privado, com a desvalorização das propriedades (o chamado passivo ambiental), além de danos ao meio ambiente (Sanchez 2001). Os combustíveis líquidos são os contaminantes mais comumente encontrados nessas áreas. Por estar em contato direto com tanques de combustíveis, o solo ou sedimento é contaminado de forma direta e podem permitir que essa contaminação migre para outros ambientes, como corpos d'água e atmosfera.

Dados da CETESB (Companhia de Tecnologia de Saneamento Ambiental do Estado de São Paulo) revelam que a comercialização de derivados do petróleo na Cidade de São Paulo, em especial a gasolina, tem gerado um número significativo de casos de vazamento de combustíveis, causados pela falta de manutenção de equipamentos, deterioração de tanques e tubulações, e falhas operacionais decorrentes do despreparo dos profissionais que atuam nesses estabelecimentos.

Desde maio de 2002, a CETESB vem divulgando listagens de áreas contaminadas no Estado de São Paulo. Na primeira listagem registrou-se a existência de 255 áreas contaminadas e após sete atualizações, em novembro de 2008, o número de áreas contaminadas era de 2.514 (Figura 1) (CETESB 2008). Deste total, 78\% (ou 1.953) são postos de combustíveis (Figura 2A). De todos os postos de combustíveis declarados áreas contaminadas, 657 localizam-se na Cidade de São Paulo, ou seja, 33\% deles (Figura 2B). Com exceção da Cidade de São Paulo, os demais municípios da Região Metropolitana de São Paulo (RMSP) possuem, no conjunto, 359 postos declarados áreas contaminadas, os quais somados aos postos da capital atingem um total de 1.016 áreas contaminadas, ou seja, 52\% das áreas contaminadas no estado. Incluindo-se os 119 postos declarados na região do Vale do Rio Paraíba do Sul, tem-se um total de 1.135 postos de combustíveis, ou seja, 58\% dos declarados como áreas contaminadas do estado (Figura 2C). 


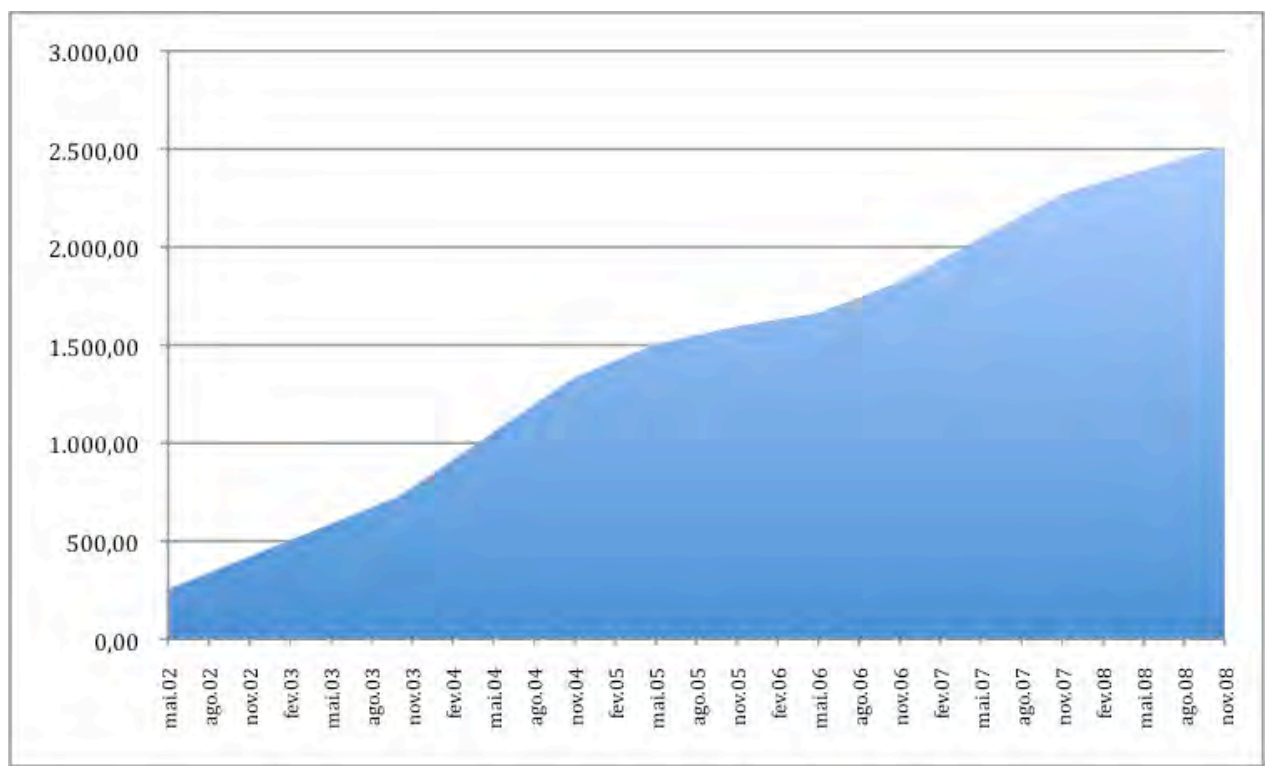

Figura 1 - Evolução das áreas contaminadas identificadas no Estado de São Paulo (CETESB, 2008).

Numa visão bastante conservadora, em um posto de abastecimento há pelo menos um tanque de gasolina, com capacidade em geral de 15.000 litros. A multiplicação desse volume de combustível pela quantidade de postos declarados áreas contaminadas na Cidade de São Paulo, resulta em 9.855.000 litros de gasolina em áreas declaradas contaminadas. Esse valor não supõe a existência de tanques com gasolina aditivada, gasolina premium, diesel e álcool. Se esse ensaio acerca da quantidade de combustível com real possibilidade de vazar para o subsolo for estendido para a RMSP, encontra-se 15.240.000 litros e, se acrescida a região do Vale do Rio Paraíba do Sul, há 17.025.000 litros armazenados em áreas contaminadas. Se apenas $1 \%$ deste volume vazasse para o subsolo, haveria um volume de 170.250 litros de gasolina impactando o subsolo. Essa situação poderia ser agravada se fosse ainda considerado todo o sistema de bases de distribuição de combustível, onde os volumes de combustíveis movimentados são, no mínimo, 100 vezes maiores do que um posto de combustível.
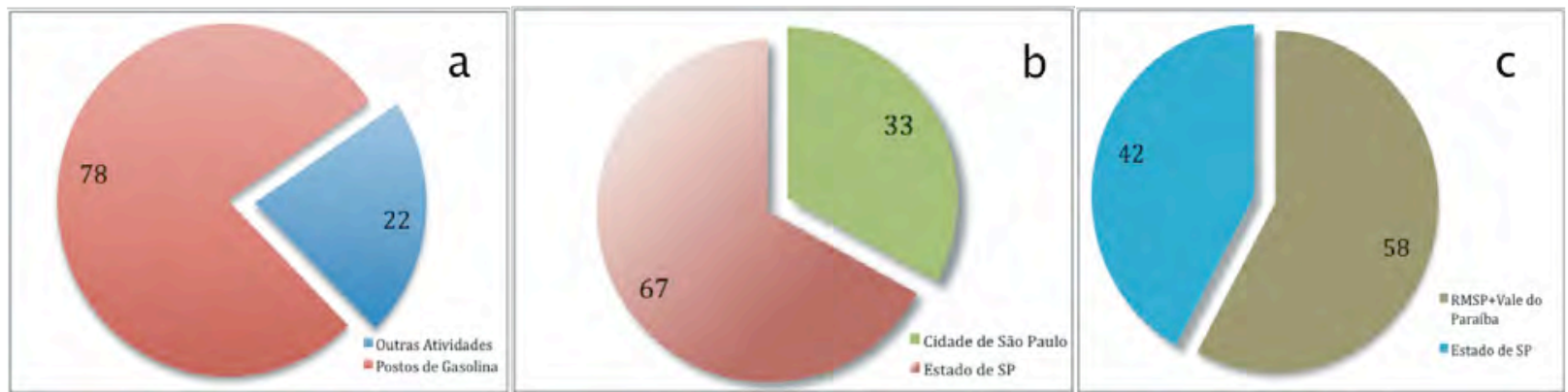

Figura 2 - (a) Representação (em porcentagem) das áreas contaminadas no Estado de São Paulo, relacionadas a postos de gasolina e a outras atividades. (b) Representação (em porcentagem) de postos de combustíveis declarados áreas contaminadas na Cidade de São Paulo e no Estado de São Paulo. (c) Representação (em porcentagem) de postos de combustíveis declarados áreas contaminadas na RMSP (incluindo Cidade de São Paulo) e Vale do Rio Paraíba do Sul, em comparação com o restante do Estado de São Paulo. Fonte dos dados: CETESB (2008).

Grande parte da área urbana da Cidade de São Paulo está estabelecida sobre os depósitos sedimentares de idade cenozóica da Bacia de São Paulo. Dentre as unidades presentes, a Formação Resende apresenta distribuição generalizada na bacia e espessura 
máxima estimada em 256 m (Takyia 1991), compreendendo mais de 80\% do preenchimento sedimentar da bacia (Riccomini \& Coimbra 1992). A unidade encerra depósitos fanglomeráticos de leques aluviais, que gradam para depósitos lamíticos e arenitos relacionados à planície aluvial de rios entrelaçados (Riccomini et al. 2004). Argilominerais esmectíticos predominam na fração fina dos sedimentos da Formação Resende (Sant'Anna 1999).

Ainda que alguns estudos apontem que os argilominerais do grupo das esmectitas possam, potencialmente, absorver compostos orgânicos (e.g. Li \& Gupta 1994), devido às suas propriedades estruturais e químicas e à alta capacidade de troca catiônica, Perlinger \& Eisenreich (1991) reconheceram que a adsorção de compostos orgânicos aos argilominerais é o principal mecanismo de retardamento do transporte de hidrocarbonetos nos solos ou sedimentos, uma vez que outros processos naturais, como biodegradação, fotólise e volatilização não ocorrem, ou atuam em taxas muito lentas em subsuperfície.

O potencial de sorção das esmectitas tem estimulado a pesquisa e o desenvolvimento de vários materiais sorventes, como as argilas organofílicas (e.g. Sharmasarkar et al. 2000, Lo \& Yang 2001, Vianna 2005, Pereira et al. 2005), para a remediação de áreas contaminadas com compostos orgânicos. As argilas organofílicas já foram obtidas por vários autores, a partir do tratamento de argilas esmectíticas naturais, em geral bentonitas, com sais de quaternário de amônio (e.g. Valenzuela Diaz 1994), o que aumenta o espaçamento interlamelar dos cristais e, portanto, sua capacidade de absorção de moléculas orgânicas. No entanto, poucos são os estudos voltados à caracterização da interação de argilas esmectíticas naturais com compostos orgânicos (e.g. Li \& Gupta 1994, Dragun et al. 1996), devido ao fato delas serem consideradas sorventes fracos quando comparadas às argilas organofílicas. Este tipo de estudo é, entretanto, importante quando voltado para uma unidade sedimentar rica em argilominerais expansíveis, em contato direto com tanques de combustíveis líquidos e que serve de substrato para uma área densamente habitada, onde são comuns casos comprovados de contaminação.

Este trabalho visa o estudo laboratorial da interação, por meio de sorção e desorção, de hidrocarbonetos encontrados comumente, como gasolina comercial, benzeno, tolueno e xilenos, com argilominerais esmectíticos da Formação Resende, no contexto da zona vadosa, na Bacia de São Paulo.

A gasolina comercial foi escolhida para representar uma situação o mais próximo possível da real. Benzeno, tolueno e xilenos são os principais compostos da gasolina em volume, sendo comumente utilizados como indicadores de contaminação envolvendo hidrocarbonetos. Estes compostos foram também usados como fases puras, não diluídas em água, de forma a permitir a compreensão da interação com os argilominerais acima da superfície freática. Esta opção deve-se ao fato dos sistemas de armazenamento subterrâneo de combustíveis possuírem a base dos seus tanques localizada, em média, a 5 $m$ de profundidade, normalmente acima do nível freático local. Nesta condição, quando há um vazamento no tanque, a zona vadosa é a primeira ser impactada, onde a porosidade intergranular, anteriormente ocupada por ar e água, torna-se saturada no contaminante (Fetter 1999). 0 contato do produto com o material (solo ou sedimento) pode proporcionar grande interação entre eles, na forma de sorção, evaporação, degradação ou migração do contaminante. Adicionalmente, a motivação para o presente estudo dedicarse à zona vadosa decorre do fato do material dessa zona poder persistir contaminado, servindo de fonte secundária mesmo quando eliminada a fonte primária da contaminação (CETESB 2008). Em alguns casos é possível sanar o problema removendo-se o material. Entretanto, quando a remoção não é viável, outras formas de diminuição da concentração de contaminantes devem ser buscadas, pois o material pode continuar como uma fonte secundária, liberando lentamente contaminantes por um longo período de tempo (CETESB 2008). 
Atualmente, existem várias técnicas para a redução da contaminação do material na zona vadosa, como bioremediação (Englert et al. 1993, Alvarez 2004), injeção de ar, injeção de óxidos, entre outras (Fetter 1999, Calabrese \& Kostecki 1993, Cole 1994, Russel Boulding \& Ginn 2004, EPA 1997, EPA 2006, Yang 2005). Essas técnicas têm sido aplicadas de forma rotineira, mas a interação do contaminante com os minerais constituintes do material nem sempre é entendida no contexto de uma determinada unidade geológica. Assim, espera-se que os resultados deste trabalho permitam avaliar como as propriedades mineralógicas desses argilominerais afetam sua capacidade de sorção (absorção, adsorção) e desorção, além de contribuir para o entendimento do comportamento e destino de contaminantes orgânicos em áreas sedimentares. A melhor compreensão dessas interações poderá proporcionar melhorias significativas no diagnóstico e remediação de áreas contaminadas e na destinação de materiais contaminados removidos. A pesquisa poderá ainda ser aplicada em outras áreas com condicionantes geológicos semelhantes, a exemplo da região do Vale do Rio Paraíba do Sul e da Cidade de Curitiba, no Estado do Paraná, ou em demais locais onde argilominerais esmectíticos sejam predominantes.

\section{Objetivos}

O objetivo geral desta pesquisa é o estudo laboratorial da interação, por meio de sorção e desorção, dos hidrocarbonetos gasolina comercial, benzeno, tolueno e xilenos (BTX) com os argilominerais esmectíticos da Formação Resende, no contexto da zona vadosa, na Bacia de São Paulo.

Como objetivos específicos pretende-se:

- caracterizar a composição mineralógica dos argilominerais esmectíticos da Formação Resende, utilizados nos testes laboratoriais;

- verificar se há absorção de gasolina e BTX pelos argilominerais esmectíticos por meio de teste de inchamento e análise por difração de raios X;

- medir a adsorção de gasolina e BTX pelos argilominerais esmectíticos em diferentes tempos de contato entre os contaminantes não diluídos e a amostra;

- medir a desorção de gasolina e BTX pelos argilominerais esmectíticos em diferentes tempos de evaporação;

- verificar se há mudanças nas capacidades de adsorção e desorção do sedimento em função da granulação (rocha total, frações silte e argila) e da composição mineralógica (maior ou menor proporção de argilomineral).

\section{Levantamento bibliográfico}

\subsection{Contexto geológico regional}

A Bacia de São Paulo integra o denominado Sistema de Rifts da Serra do Mar (Almeida 1976), posteriormente designado de Rift Continental do Sudeste do Brasil (RCSB) por Riccomini (1989), feição tectônica de idade cenozóica, desenvolvida entre as cidades de Tijucas do Sul, no Estado do Paraná, e a área submersa defronte a Macaé, no Estado do Rio de Janeiro, numa extensão de pouco mais de $900 \mathrm{~km}$. Morfologicamente, o RCSB 
apresenta-se como uma faixa estreita e deprimida, alongada segundo a direção ENE, seguindo a linha de costa atual, da qual dista em média cerca de $70 \mathrm{~km}$, alcançando o Oceano Atlântico em suas terminações sudoeste e nordeste. O RCSB abrange mais de uma dezena de bacias sedimentares (Riccomini et al. 2004), sendo as principais, pelas suas dimensões, as bacias de Taubaté, São Paulo e Curitiba (Figura 3).

0 embasamento do RCSB compreende gnaisses e migmatitos de idade arqueana a neoproterozóica do Cinturão Ribeira (Almeida et al. 1973), metassedimentos de natureza diversificada e metavulcânicas básicas pertencentes aos grupos São Roque e Serra do Itaberaba (Juliani 1993), ampla variedade litológica (gnaisses, xistos, anfibolitos, quartzitos e rochas calciossilicatadas) agrupadas no Complexo Embu (Hasui \& Sadowski 1976, Machado Filho et al. 1983), e suítes graníticas de idade neoproterozóica (Janasi \& Ulbrich 1991). Estas rochas estão seccionadas por densa trama de zonas de cisalhamento, ativas até o final do Ciclo Brasiliano, no Cambro-Ordoviciano (Sadowski \& Motidome 1987).

Numerosos corpos de rochas alcalinas eocretáceas a paleógenas ocorrem ao longo das bordas do rift (Riccomini et al. 2004), constituindo cerca de trinta intrusões isoladas e destacando-se, pelas suas dimensões, os maciços de Itatiaia (idade média K-Ar de $73 \mathrm{Ma}$, Lauar 1988) e Passa Quatro (idade K-Ar de 67 Ma, Sonoki \& Garda 1988), compostos essencialmente por nefelina sienitos (Figura 3).

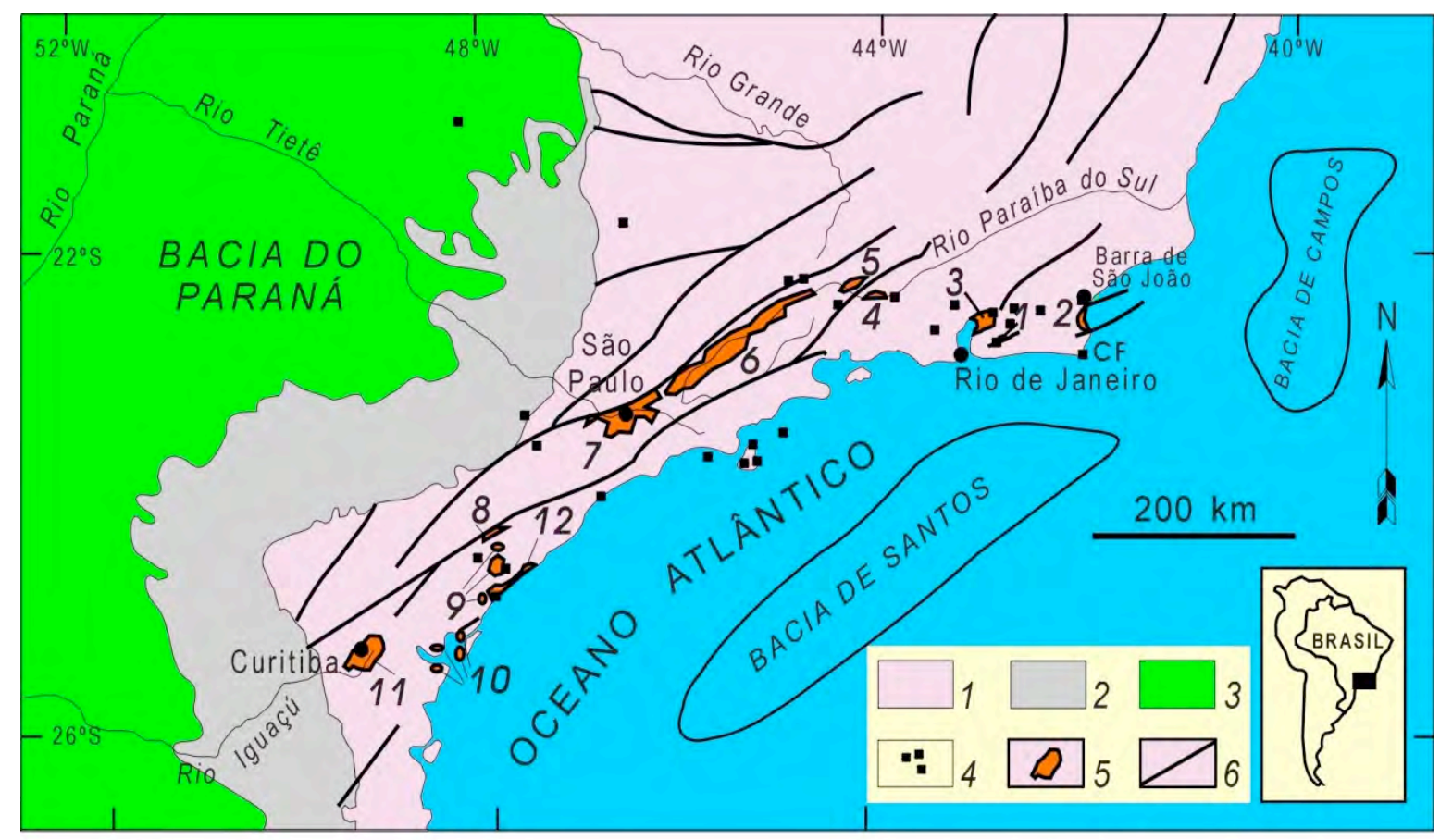

Figura 3 - Contexto geológico regional do Rift Continental do Sudeste do Brasil (RCSB) (Riccomini et al. 2004): 1) embasamento pré-cambriano; 2) rochas sedimentares paleozóicas da Bacia do Paraná; 3) rochas vulcânicas eocretáceas da Formação Serra Geral; 4) rochas relacionadas ao magmatismo alcalino mesozóico-cenozóico; 5) bacias cenozóicas do rift (1- Bacia de Itaboraí, 2- Graben de Barra de São João, 3- Bacia do Macacu, 4- Bacia de Volta Redonda, 5- Bacia de Resende, 6- Bacia de Taubaté, 7- Bacia de São Paulo, 8- Graben de Sete Barras, 9- Formação Pariqüera-Açu, 10- Formação Alexandra e Graben de Guaraqueçaba, 11- Bacia de Curitiba, 12- Graben de Cananéia); 6) zonas de cisalhamento pré-cambrianas, em parte reativadas durante o Mesozóico e Cenozóico. 
Durante o Paleógeno, zonas de cisalhamento neoproterozóicas de direção NE a E-W, reativadas inicialmente como falhas normais e posteriormente transcorrentes, permitiram a instalação e deformação das bacias que compõem o RCSB, incluindo a Bacia de São Paulo (Riccomini et al. 2004). A formação da depressão original do RCSB decorreu dos processos relacionados à abertura do Oceano Atlântico, quando as zonas de cisalhamento neoproterozóicas de direção NE a E-W do embasamento pré-cambriano foram reativadas como falhas normais no início do Paleógeno (Riccomini 1989). Posteriormente, a reativação dessas estruturas como falhas transcorrentes no Paleógeno e Neógeno levaram à separação das bacias que compõem o rift e à configuração atual (Riccomini et al. 2004).

\subsection{A Bacia de São Paulo}

A Bacia de São Paulo é um hemi-graben basculado para NNW, com borda norte retilínea controlada pela zona de cisalhamento Taxaquara-Jaguari e contatos irregulares com o embasamento cristalino pré-cambriano na borda sul (Riccomini et al. 2004) (Figura 4).

Segundo Riccomini \& Coimbra (1992), os depósitos sedimentares paleógenos da Bacia de São Paulo apresentam área de distribuição muito irregular, com pouco mais de 1.000 $\mathrm{km}^{2}$. Os sedimentos ocorrem entre Arujá e Embu-Guaçú, numa extensão de $75 \mathrm{~km}$, e entre Santana e Santo André, com cerca de $25 \mathrm{~km}$, respectivamente os eixos maior e menor da bacia. Outras ramificações, de pequena extensão em área, ocorrem para leste, passando por Mogi das Cruzes, Biritiba Mirim e alcançando os arredores de Salesópolis e, para o sul, até Engenheiro Marsillac. As maiores espessuras de sedimentos paleógenos encontram-se ao norte da área (região de Guarulhos), e a leste (Moóca, Tatuapé e Vila Formosa), onde ultrapassam os $170 \mathrm{~m}$. No corpo principal de sedimentos da bacia, a espessura máxima contínua preservada atinge 290 m na sondagem no 384 do Departamento de Águas e Energia Elétrica - DAEE, perfurada no bairro da Moóca (Takiya 1991). 0 preenchimento sedimentar paleógeno da bacia é representado pelo Grupo Taubaté, formado por depósitos continentais paleógenos das formações Resende, Tremembé e São Paulo, sendo recoberto, de forma presumivelmente discordante, pela Formação Itaquaquecetuba, neógena (Riccomini 1989) (Figura 4).

A Formação Resende, unidade basal e lateral do Grupo Taubaté (Figura 5), de idade eocena-oligocena (Riccomini et al. 1983, Lima \& Amador 1985, Yamamoto 1995), foi originalmente definida por Amador (1975) na bacia homônima, onde está localizada a sua seção-tipo. Na Bacia de São Paulo, a Formação Resende apresenta distribuição generalizada, compreendendo mais de $80 \%$ do seu preenchimento sedimentar (Riccomini 1989). A unidade é formada por fanglomerados e lamitos de leques aluviais, que gradam para depósitos arenosos de planície aluvial de rios entrelaçados.

A Formação Resende interdigita-se lateral e verticalmente com o sistema lacustre da Formação Tremembé (Figura 5), de idade oligocena (Riccomini et al. 1987, Lima \& Melo, 1989), presente na parte centro-norte da Bacia de São Paulo (Melo et al. 1986, Riccomini \& Coimbra 1992, Sant'Anna 1999), onde os depósitos essencialmente argilosos podem superar $60 \mathrm{~m}$ de espessura.

A Formação São Paulo corresponde a um sistema fluvial meandrante oligoceno que encerra a sedimentação do Grupo Taubaté (Figura 5), e cujos depósitos, predominantemente areno-argilosos, têm sua principal área de exposição no espigão central da Cidade de São Paulo, ao longo da Rua Heitor Penteado e das avenidas Doutor Arnaldo, Paulista, Vergueiro e Domingos de Moraes, em cotas superiores a 750-760 m e podendo atingir espessura da ordem de $70 \mathrm{~m}$ (Riccomini \& Coimbra 1992).

Os depósitos areno-conglomeráticos do sistema fluvial entrelaçado da Formação Itaquaquecetuba (Coimbra et al. 1983), de idade miocena (Yamamoto 1995), têm sua áreatipo na margem direita do Rio Tietê, em Itaquaquecetuba, onde a formação possui 
espessura máxima estimada de cerca de $50 \mathrm{~m}$. Essa unidade apresenta-se com contatos ora erosivos, ora tectônicos, unicamente com rochas do embasamento pré-cambriano, não tendo sido, até o presente momento, verificada relação com o Grupo Taubaté (Figura 5).

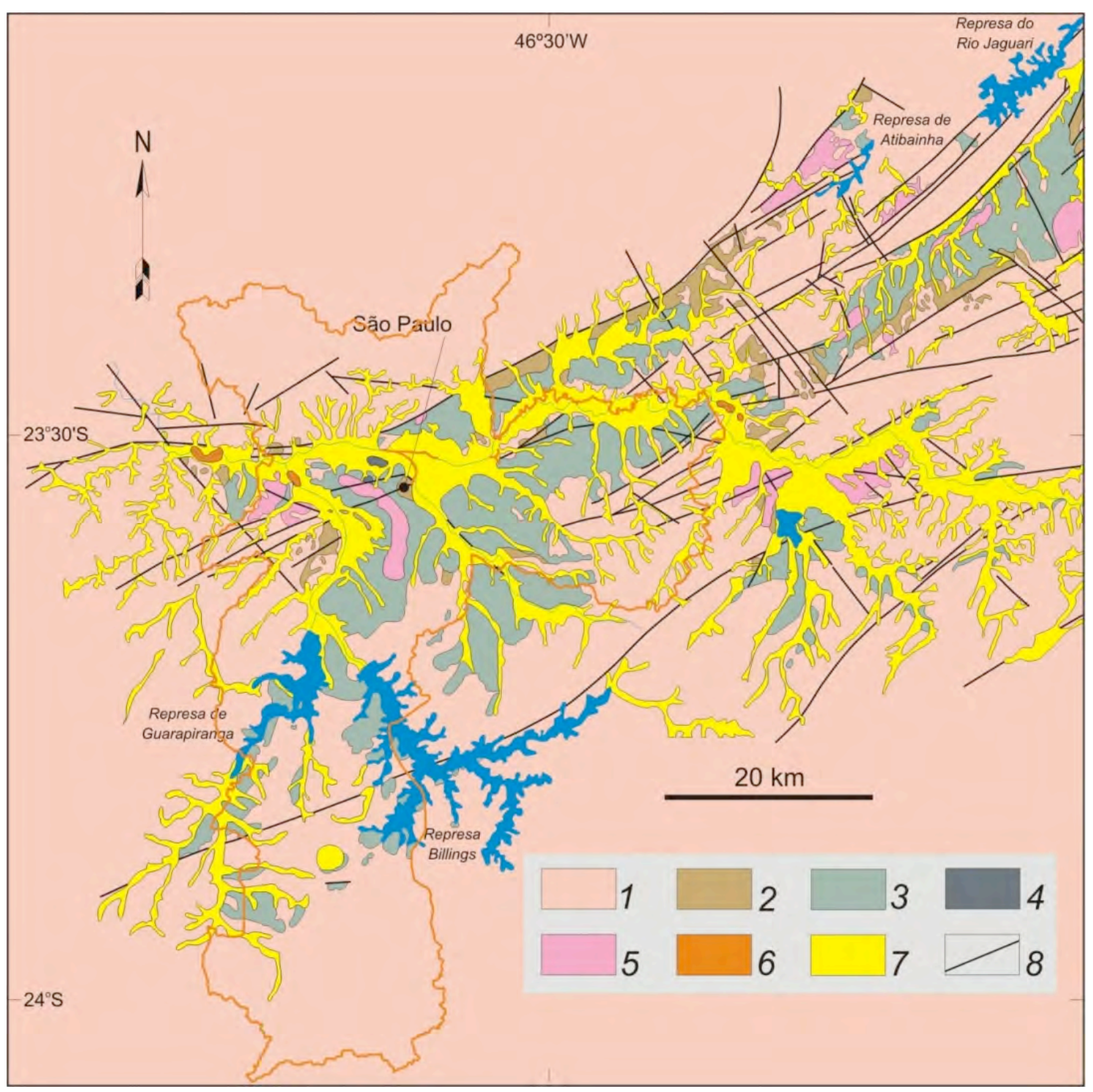

Figura 4 - Mapa geológico da Bacia de São Paulo e porção sudoeste da Bacia de Taubaté (Riccomini et al. 2004): 1) embasamento pré-cambriano; 2) Formação Resende (sistema de leques aluviais proximais); 3) Formação Resende (sistema de leques aluviais medianos a distais associados a planície aluvial de rios entrelaçados); 4) Formação

Tremembé; 5) Formação São Paulo; 6) Formação Itaquaquecetuba; 7) sedimentos quaternários; 8) falhas cenozóicas, em parte reativadas do embasamento pré-cambriano. 0 traçado contínuo de cor laranja representa os limites do Município de São Paulo.

As unidades paleógenas do Grupo Taubaté predominam no substrato das zonas oeste, central e leste da Cidade de São Paulo (Figura 4), onde sustentam o relevo formado por morros e espigões relativamente baixos, em sua maior parte com 715 a $900 \mathrm{~m}$ de altitude, que caracterizam a Bacia de São Paulo no Planalto Paulistano (Almeida 1958). As rochas do embasamento pré-cambriano são dominantes, principalmente, nas zonas norte e sul da cidade, onde compõem porções mais elevadas do relevo.

Associações colúvio-aluviais, com espessuras de 4 a $5 \mathrm{~m}$ e idade pleistocena a holocena (Figura 5), apresentam distribuição relativamente restrita, acompanhando grosso modo a topografia atual (IPT 1986). Uma revisão e integração regional desses depósitos foram 
apresentadas por Turcq \& Melo (1989). A rede de drenagem atual flui para o Rio Tietê, o principal rio que cruza a área, onde coberturas aluviais quaternárias predominam e constituem os relevos mais baixos na Cidade de São Paulo (Figura 4).

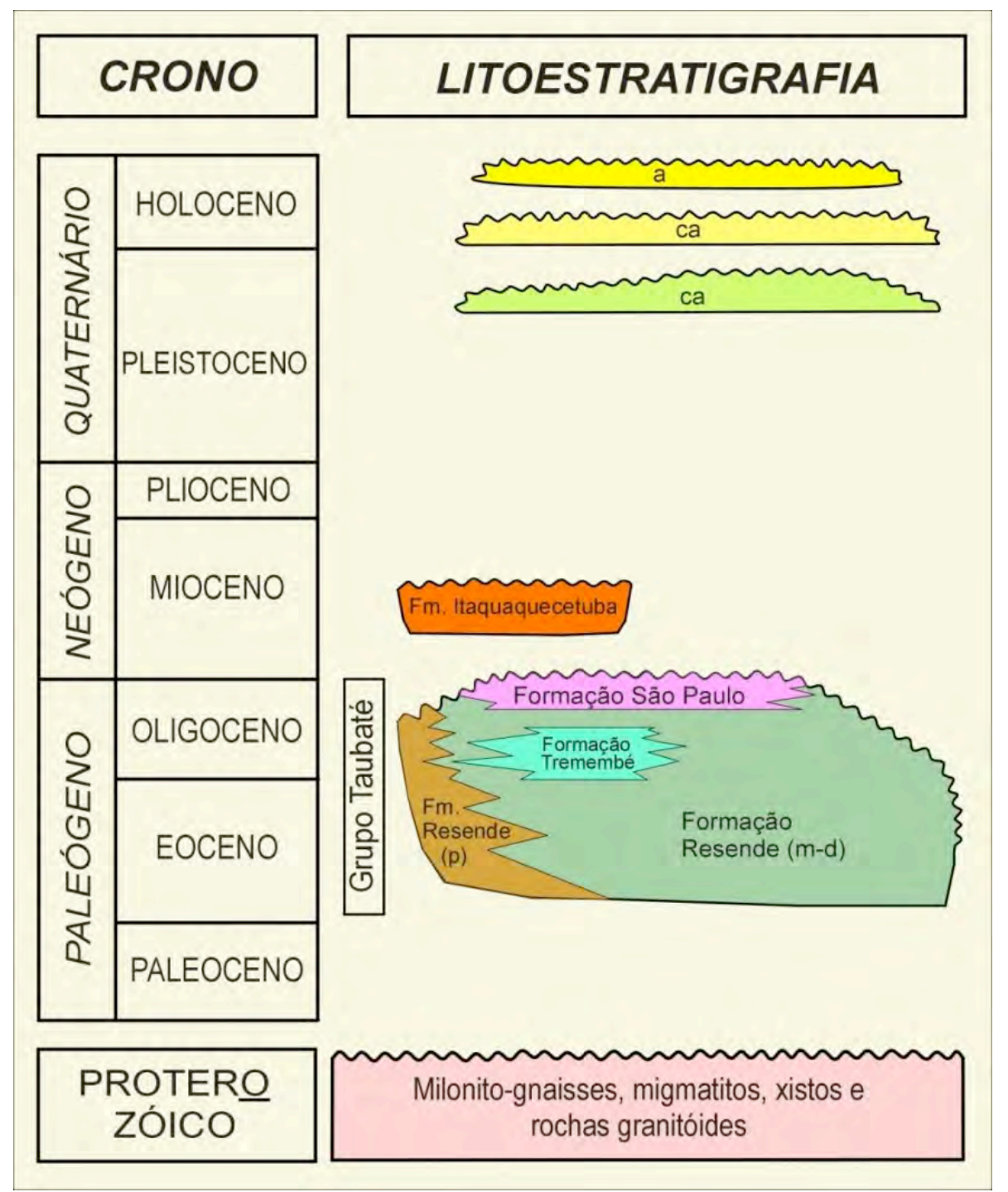

Figura 5 - Quadro litoestratigráfico da Bacia de São Paulo (modificado de Riccomini et al. 2004). Letras: p leques aluviais proximais; $\mathrm{m}$ - $\mathrm{d}$ - leques aluviais medianos a distais associados à planície aluvial de rios entrelaçados; ca - depósitos colúvio-aluviais; a - depósitos aluviais.

\subsection{Formação Resende}

A Formação Resende compreende um sistema de leques aluviais associados a planícies aluviais de rios entrelaçados originado durante a fase de instalação do RCSB, sendo representativa da sedimentação que acompanhou os eventos tectônicos geradores do rift (Riccomini 1989).

As principais litofácies da Formação Resende correspondem a diamictitos e conglomerados nas porções proximais do sistema de leques aluviais, e lamitos arenosos a argilosos nas posições distais, existindo a transição entre elas nas porções medianas dos leques. Arenitos grossos a médios, com estratificação cruzada acanalada de médio porte, são representativos da sedimentação em planície aluvial de rios entrelaçados. As fácies de diamictitos e conglomerados da Formação Resende situam-se nas posições basais e 
laterais do rift, em estreita relação com as zonas de falhas que limitam as depressões, e as fácies de lamitos arenosos a argilosos e arenitos ocorrem nas porções mais interiores das bacias (Riccomini \& Coimbra 1992).

Os depósitos de leques aluviais proximais incluem diamictitos e conglomerados com seixos, matacões e blocos angulosos a subarredondados, normalmente polimíticos, dispersos em matriz essencialmente lamítica a arenosa, de coloração no geral esverdeada quando não alterada. Apresentam gradação normal e inversa, ocorrendo acunhamento dos pacotes rumo às porções mais centrais da bacia. Rumo ao interior da depressão, esses sedimentos gradam para lamitos predominantemente arenosos de coloração esverdeada e arenitos de coloração esverdeada a esbranquiçada ou acinzentada, estes exibindo localmente estratificação cruzada acanalada de médio porte e níveis conglomeráticos com seixos constituídos predominantemente por quartzo e quartzito e mais localmente, feldspatos e rochas do embasamento. Estes arenitos constituem corpos de geometria tabular e dimensão métrica, depositados em rios entrelaçados (braided) e interdigitados com conglomerados e diamictitos proximais. Localmente podem ser observados corpos de extensão métrica e espessura decimétrica (até pouco mais de $1 \mathrm{~m}$ ) constituídos, essencialmente, por arenitos de granulação média a grossa, mal selecionados, em meio a sedimentos essencialmente síltico-argilosos. Em outros casos, na parte oeste da Bacia de São Paulo (região do Bairro do Rio Pequeno), estes arenitos ocorrem sob a forma de extensos lençóis, com espessura métrica e estratificação cruzada acanalada, no topo de depósitos de lamitos (Riccomini et al. 2004).

Sant'Anna (1999) realizou o estudo mineralógico, geoquímico e genético dos argilominerais da Formação Resende, presente nas bacias de São Paulo, Taubaté, Resende e Volta Redonda, e da Formação Guabirotuba, unidade correlata na Bacia de Curitiba. A partir dos dados obtidos foi possível reconhecer a homogeneidade das composições mineralógica e geoquímica desses argilominerais no contexto regional. Predominam esmectitas e interestratificados illita-esmectita desordenados com alta proporção de esmectita (> 50\%), exibindo forma de placas com bordas onduladas que evidenciam a origem detrítica. Esses argilominerais respondem pela coloração esverdeada dos sedimentos, em especial dos lamitos, onde predominam e associam-se a proporções menores, ainda que variáveis, de grãos de quartzo, feldspato, mica e minerais máficos (Suguio 1969, Sant'Anna 1999, Sant'Anna et al. 2003). Nos arenitos fluviais, os argilominerais esmectíticos constituem a matriz argilosa de infiltração que envolve os grãos de quartzo e feldspato do arcabouço (Goenopawiro 1997, Sant'Anna 1999). A origem dos argilominerais esmectíticos é atribuída a paleossolos formados pela alteração intempérica (intemperismo químico) das rochas do embasamento pré-cambriano, indicadas como as principais áreas fontes dos depósitos lamíticos da Formação Resende, a partir de análises isotópicas $\mathrm{Sm} / \mathrm{Nd}$ de rocha total com idades modelo $\mathrm{T}_{\mathrm{DM}}$ variando entre 1,7 e 2,2 Ga (Sant'Anna et al. 2003).

\subsection{Definição, estrutura e classificação dos argilominerais}

A conceituação do termo argilomineral esteve, por muitas décadas, intimamente relacionada e por vezes confundida com a definição do termo argila, este último uma designação usual para tamanho de partícula menor do que $2 \mu$ m (Atterberg 1905) ou menor do que $4 \mu \mathrm{m}$ (Wentworth 1922). No entanto, como muitos tipos de minerais podem ocorrer em materiais naturais, especialmente solos e sedimentos, com tamanho argila (Velde 1992), o Comitê de Nomenclatura da AIPEA (Association International pour l'Etude des Argiles), reunido em 1972, em Madri, definiu o conceito de argilomineral como "argilominerais pertencem a família dos filossilicatos e contêm folhas tetraédricas bidimensionais e contínuas de composição $\mathrm{T}_{2} \mathrm{O}_{5}(\mathrm{~T}=\mathrm{Si}, \mathrm{Al}, \mathrm{Be} \ldots)$ com tetraedros ligados pela partilha de três vértices cada um, e com o quarto vértice apontando para qualquer 
direção. As folhas tetraédricas estão ligadas às folhas octaédricas na unidade estrutural, ou a grupos de cátions coordenados, ou a cátions individuais (Bailey 1980).

Esta definição foi posteriormente rediscutida e Guggenheim \& Martin (1995) relataram as decisões dos comitês de nomenclatura da AIPEA e da CMS (Clay Minerals Society), segundo as quais o termo argilomineral refere-se a minerais filossilicáticos e minerais que emprestam plasticidade à argila e que endurecem após ressecamento ou aquecimento. A ampliação da definição mineralógica de Bailey (1980), de forma a incluir o comportamento de argilas ricas em argilominerais, deve-se à franca predominância desses minerais na fração argila de solos e sedimentos (Velde 1995) e às várias possibilidades de emprego tecnológico desses materiais.

Assim, argilominerais são atualmente entendidos como substâncias minerais com características mineralógicas e propriedades tecnológicas definidas, ocorrentes como partículas de dimensões diminutas e que quimicamente correspondem a silicatos hidratados de alumínio, ferro e magnésio (Velde 1995, Bergaya \& Lagaly 2006).

Uma das principais características dos argilominerais é sua estrutura em folhas, que podem ser tetraédricas ou octaédricas de acordo com o tipo de cavidade formada pelo arranjo aniônico. Íons de oxigênio e de hidroxila são os principais ânions da estrutura e os cátions mais comuns são silício e alumínio, nas cavidades tetraédricas, e alumínio, ferro e magnésio, nas octaédricas. Algumas definições importantes para a compreensão da estrutura e classificação dos argilominerais (Caillère et al. 1982, Velde 1992) são:

- plano de átomos: construção bidimensional definida por uma família de átomos (ex: plano basal de oxigênios);

- folha (tetraédrica ou octaédrica): sub-estrutura bidimensional formada pelas unidades tetraédricas ou octaédricas;

- camada: formada pela combinação das folhas, podendo ser uma camada do tipo 1:1 (formada pela superposição de uma folha tetraédrica a uma octaédrica) ou 2:1 (duas tetraédricas para uma octaédrica). Há ainda camadas do tipo 2:1:1, onde a quarta folha é do tipo octaédrica;

- materiais interlamelares: cátions, cátions hidratados, moléculas orgânicas, folhas e grupos octaédricos de hidróxidos;

- unidade estrutural: camada + material interlamelar.

A principal classificação dos argilominerais é efetuada em função da razão entre as folhas tetraédricas e octaédricas nas camadas, o que gera uma nomenclatura própria, na qual os argilominerais são enquadrados nos tipos camada 1:1, 2:1 ou 2:1:1 (Moore \& Reynolds 1997) (Tabela 1). Grupos de argilominerais são definidos para os vários tipos, diferenciando-se pela magnitude da carga da camada, que pode variar de zero (eletricamente neutra devido ao balanceamento das cargas positivas e negativas) a aproximadamente 2,0 (com cargas negativas não balanceadas). 
Tabela 1 - Classificação dos filossilicatos, com ênfase nos argilominerais (adaptado de Moore \& Reynolds 1997).

\begin{tabular}{|c|c|c|c|}
\hline $\begin{array}{l}\text { Tipo de } \\
\text { camada }\end{array}$ & Grupo & Subgrupo & Espécie \\
\hline \multirow[t]{2}{*}{$1: 1$} & \multirow{2}{*}{$\begin{array}{l}\text { Serpentina-Caulinita } \\
\qquad(z \sim 0)\end{array}$} & Serpentina (tr) & $\begin{array}{l}\text { Crisotila, antigorita, lizardita, } \\
\text { berthierine, odinite }\end{array}$ \\
\hline & & Caulinita (di) & Caulinita, dickita, nacrita, halloysita \\
\hline \multirow{12}{*}{$2: 1$} & $\begin{array}{l}\text { Talco-pirofilita } \\
\qquad(\mathrm{z} \sim 0)\end{array}$ & $\begin{array}{l}\text { Talco (tr) } \\
\text { Pirofilita }\end{array}$ & \\
\hline & \multirow{2}{*}{$\begin{array}{l}\text { Esmectita } \\
(\mathrm{z} \sim 0,2-0,6)\end{array}$} & Esmectita (tr) & Saponita, hectorita \\
\hline & & Esmectita (di) & Montmorilonita, beidellita, nontronita \\
\hline & $\begin{array}{l}\text { Vermiculita } \\
(\mathrm{z} \sim 0,6-0,9)\end{array}$ & $\begin{array}{l}\text { Vermiculita (tr) } \\
\text { Vermiculita (di) }\end{array}$ & \\
\hline & $\begin{array}{c}\text { Ilita } \\
(0,6>z<0,9)\end{array}$ & $\begin{array}{l}\text { Ilita (tr) } \\
\text { Ilita (di) }\end{array}$ & Ilita, glauconita \\
\hline & \multirow{2}{*}{$\begin{array}{c}\text { Mica } \\
(z \sim 1,0) \\
(z \sim 2,0)\end{array}$} & Mica (tr) & Biotita, flogopita, lepidolita \\
\hline & & Mica (di) & Muscovita, paragonita, margarita \\
\hline & \multirow{4}{*}{$\begin{array}{c}\text { Clorita } \\
\text { (z variável) }\end{array}$} & Clorita (tr,tr) & \\
\hline & & Clorita (di, di) & Donbassite \\
\hline & & Clorita (di, tr) & Sudoite, cookeite \\
\hline & & Clorita (tr, di) & Sem exemplos conhecidos \\
\hline & Sepiolita - paligorskita & Fita & tidas (com z variável) \\
\hline
\end{tabular}

$\mathrm{Tr}$ - trioctaédrico; Di - dioctaédrico

Uma classificação em subgrupos é feita de acordo com o tipo de cátion presente na folha octaédrica, podendo existir argilominerais trioctaédricos, com todos os sítios octaédricos ocupados por cátions divalentes (em geral, $\mathrm{Fe}^{2+}, \mathrm{Mg}^{2+}$ ), e argilominerais dioctaédricos, com somente dois terços dos sítios ocupados por cátions trivalentes (comumente $\mathrm{Al}^{3+}, \mathrm{Fe}^{3+}$ ) (Tabela 2). A seguir, espécies de argilominerais são definidas para cada subgrupo em função de variações menores na estrutura ou composição química.

Tabela 2 - Ocupação dos sítios octaédricos (adaptado de Moore \& Reynolds 1997).

\begin{tabular}{cccc}
\hline Nome da Folha & Cátion & Cátion/Oxigênios & Sítios Ocupados \\
\hline Trioctaédica & Divalente & $1: 2$ & 3 de 3 \\
Dioctaédrica & Trivalente & $1: 3$ & 2 de 3 \\
\hline
\end{tabular}

\subsection{Classificação do grupo das esmectitas}

Esmectitas são argilominerais com camada do tipo 2:1, formada por duas folhas tetraédricas contendo normalmente silício e alumínio, que envolvem uma folha octaédrica contendo principalmente alumínio, magnésio e ferro ( $\mathrm{Fe}^{2+}$ ou Fe${ }^{3+}$ ) (Figura 6) (Dixon 1989, Moore \& Reynolds 1997). As esmectitas formam um grupo com várias espécies de argilominerais agrupadas em dois subgrupos, um dioctaédrico e outro trioctaédrico (Tabela 1). Estas espécies diferenciam-se pelo tipo de cátion predominante na folha octaédrica. As espécies dioctaédricas são a montmorillonita ( $\mathrm{Al}, \mathrm{Fe}$ ou $\mathrm{Mg}$ ), beidellita ( $\mathrm{Al}$ ) e nontronita $(\mathrm{Fe})$, e as espécies trioctaédricas são a saponita $(\mathrm{Mg}, \mathrm{Fe})$ e a hectorita $(\mathrm{Mg}, \mathrm{Li})$, as quais apresentam carga variando de 0,2 a 0,6 (Brigatti et al. 2006). 


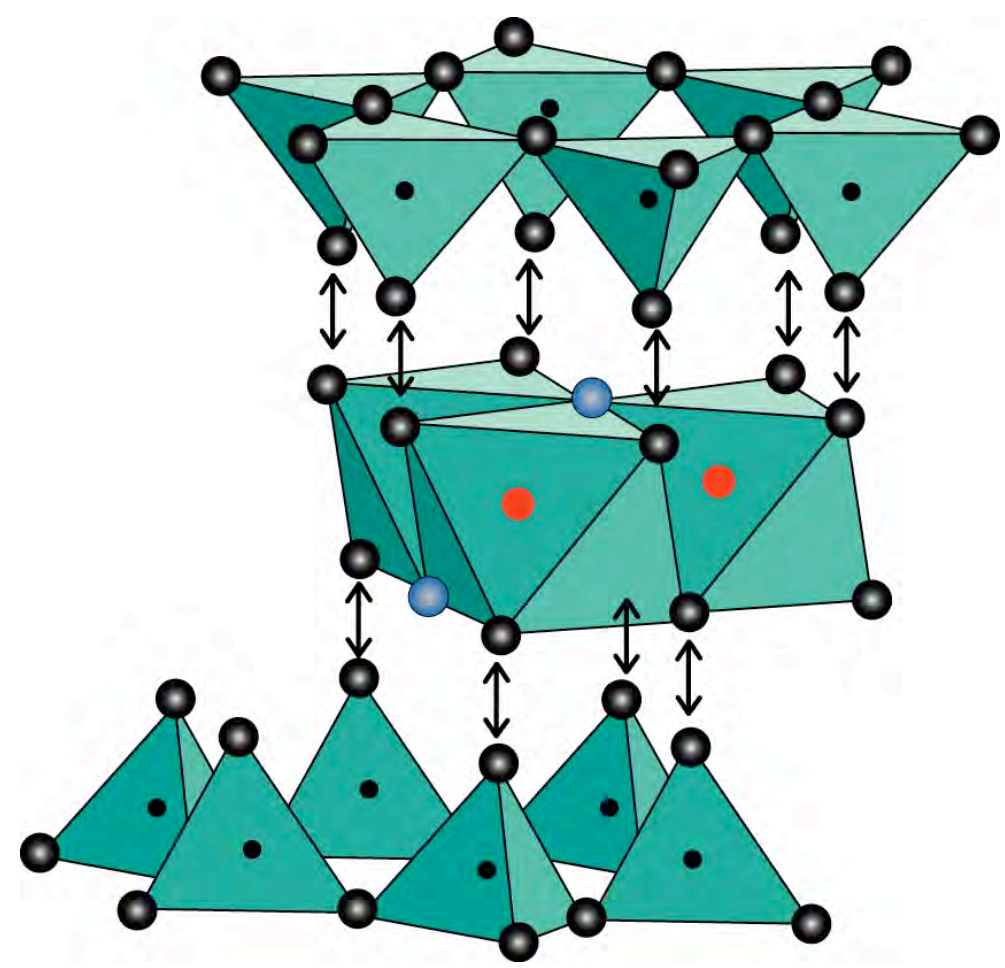

Figura 6 - Poliedro tridimensional mostrando a estrutura idealizada de um argilomineral 2:1 (adaptado de Moore \& Reynolds 1997). Legenda: esferas azuis grandes representam hidroxilas; esferas pretas grandes são oxigênios; esferas pretas pequenas são cátions nas cavidades tetraédricas; esferas vermelhas grandes são cátions nas cavidades octaédricas.

No espaço interlamelar das esmectitas podem acomodar-se moléculas de água coordenando cátions trocáveis $\left(\mathrm{K}^{+}, \mathrm{Na}^{+}, \mathrm{Ca}^{2+}\right)$ e moléculas orgânicas. $\mathrm{O}$ espaçamento entre as unidades estruturais (camada + material interlamelar) pode variar, sendo bem observado na espécie montmorillonita, que apresenta 12,5 Å quando o cátion interlamelar é o $\mathrm{Na}^{+}$, e $15,5 \AA$ A quando é $\mathrm{Ca}^{2+}$. A substituição da água interlamelar por um composto orgânico, como etilenoglicol ou glicerol, expande a estrutura para 17-17,5 ̊.

\subsection{Formação dos argilominerais}

No ciclo geológico, a formação e distribuição dos argilominerais estão restritas aos processos que ocorrem na parte superior da crosta terrestre, onde eles são abundantes (Velde 1995). Os processos geológicos envolvidos são o intemperismo, a sedimentação, a diagênese por soterramento e a alteração hidrotermal. Em decorrência desses processos, os argilominerais são abundantes em solos, sedimentos, rochas sedimentares e nas zonas de alteração hidrotermal, estando geralmente ausentes em rochas magmáticas e metamórficas (Weaver 1989).

As temperaturas de formação variam entre $4^{\circ} \mathrm{C}$ (fundo marinho) a $200^{\circ} \mathrm{C}$ (diagênese por soterramento), ainda que temperaturas próximas a $400^{\circ} \mathrm{C}$ possam ser atingidas em processos hidrotermais. O tempo requerido para a formação dos argilominerais pode variar de algumas horas, em experimentos laboratoriais e quando associados a intrusões ígneas, a centenas de milhares de anos em condições de diagênese por soterramento (Velde 1992). Assim, os campos de formação e estabilidade dos argilominerais dependem da temperatura e do tempo (de manutenção desta temperatura). A dimensão temporal é tão fundamental quanto a temperatura para a estabilidade e evolução dos argilominerais (Velde 1995). 
0 estudo dos processos formadores dos argilominerais mostra que estes se originam, principalmente, a partir de minerais preexistentes, por reações da crosta em contato com a hidrosfera ou atmosfera (Velde 1995). Assim, eles resultam da interação de uma rocha preexistente com uma solução aquosa. Os processos geoquímicos envolvidos são a dissolução ou recristalização do mineral original, que levam à formação dos argilominerais. Se água existe no meio, o sólido torna-se instável, levando à formação dos argilominerais, que é um processo incongruente, pois um sólido gera sólidos e materiais em solução. A magnitude da troca química será controlada pelos dois principais fatores determinantes da taxa de reação: temperatura e tempo.

Na crosta terrestre, os argilominerais são gerados principalmente pelo intemperismo químico atuante na superfície, sendo eles os principais constituintes dos solos. 0 grau de alteração dependerá da interação de vários fatores, que determinarão o tipo de mineral secundário formado, incluindo o clima (temperatura, umidade), o relevo (grau de drenagem ou confinamento) e a natureza da rocha-mãe (condiciona a seqüência de minerais formados).

No ambiente sedimentar, os argilominerais podem ser de origem detrítica ou autigênica, neste caso ser formado in situ pela diagênese (Chamley 1989, Weaver 1989). A partir da erosão da área fonte, os detríticos são transportados para o ambiente sedimentar, onde permanecerão como minerais herdados se forem estáveis frente às novas condições ou estarão sujeitos aos processos de transformação se instáveis (Millot 1970).

Os argilominerais esmectíticos constituintes dos lamitos da Formação Resende são de origem detrítica, tendo sido formados em paleossolos gerados pela alteração intempérica das rochas pré-cambrianas do embasamento do RCSB no início do Paleógeno, previamente à deposição da unidade. Os paleossolos esmectíticos foram transportados para os hemigrabens continentais por fluxos de lama em um sistema de leques aluviais durante o Eoceno-Oligoceno, época de deposição da Formação Resende (Sant'Anna et al. 2003).

\subsection{Gasolina}

A gasolina é um combustível líquido obtido pelo refino do petróleo, sendo composta basicamente por uma mistura de substâncias orgânicas com átomos de carbono e hidrogênio, denominadas hidrocarbonetos (IBP 2009).

Para a produção da gasolina são utilizados processos de refino em várias etapas, iniciando-se com a separação física denominada destilação, de onde são aproveitados a nafta e o gasóleo para a produção da gasolina. O gasóleo passa por um processo de craqueamento catalítico que modifica a estrutura das moléculas, de onde se obtém a nafta de craqueamento, que é misturada à nafta de destilação para a produção de gasolina. Dependendo do tipo de gasolina a ser obtido, outros processos mais sofisticados são empregados, tais como alquilação e reforma catalítica, sendo assim possível a obtenção de gasolinas de alto desempenho (IBP 2009).

No Brasil, a Petrobras produz e oferece às companhias distribuidoras a gasolina do tipo A, isenta de álcool anidro, que é a base de todas as gasolinas disponíveis nos postos revendedores. 0 álcool anidro é acrescentado à gasolina num percentual definido pelo Ministério da Agricultura e Abastecimento, em atendimento a Portaria ANP no 309 (ANP 2001). A mistura é feita nas distribuidoras antes de chegar aos postos de serviços e pode ser usada em boa parte dos veículos no país. Assim, a gasolina vendida no território brasileiro é uma mistura de gasolina A (sem álcool) com cerca de $25 \%$ de álcool etílico anidro; essa porcentagem varia de acordo com a política energética, gerando a gasolina do tipo C. A adição de álcool combustível invalida a utilização da maioria dos modelos de contaminação por gasolina obtidos em outros países, devido ao efeito cossolvente do 
etanol adicionado no Brasil (Trovão 2006). A adição do etanol, ao provocar o efeito cossolvente, reduz a espessura da fase livre e aumenta a solubilidade e a velocidade de deslocamento de plumas de gasolina, pois a menor viscosidade reduz a tensão interfacial e permite a invasão dos poros que não seriam preenchidos por gasolina pura, permitindo também a ocorrência de plumas com maior área (Oliveira \& Pereira 2006).

Sendo a gasolina uma mistura complexa de hidrocarbonetos, há dificuldade na identificação de um vazamento pela quantificação individual de seus componentes. Benzeno, tolueno, etilbenzeno e xileno (em suas três formas, orto, para e meta), denominados compostos BTEX, são hidrocarbonetos monoaromáticos constituintes da gasolina, detectados em concentrações significativas, e que têm maior solubilidade em água, sendo utilizados como indicadores para se identificar e quantificar uma contaminação (Trovão 2006). A Tabela 3 apresenta as frações dos compostos BTX na composição da gasolina brasileira.

As características físico-químicas das gasolinas tipo A e tipo C, benzeno, tolueno, etilbenzeno, xileno e álcool são sintetizadas na Tabela 4. A partir desses dados é possível prever alguns comportamentos dos compostos utilizados nesse estudo. Como pode ser observado, a gasolina tipo A é insolúvel em água. Quando o etanol é adicionado a ela, esta passa a ter um $\log K_{\text {ow }}$ de 2,7 , superior até ao do benzeno puro $(2,13)$, ou seja, a gasolina comercializada no Brasil tem características únicas, com afirmam Finotti (2003) e Pereira (2003), não sendo possível a correlação direta com modelos utilizados em outros países.

Tabela 3 - Frações dos compostos BTX nas gasolinas brasileiras (Corseuil \& Fernandes 1999).

\begin{tabular}{ccccccc}
\hline \multirow{2}{*}{ Solutos } & \multicolumn{3}{c}{ Gasolina tipo A } & \multicolumn{3}{c}{ Gasolina tipo C } \\
& \% vol. & \% massa & Fração Molar & \% vol. & \% massa & Fração Molar \\
\hline Benzeno & 0,52 & 0,608 & 0,0078 & 0,42 & 0,494 & 0,0063 \\
Tolueno & 3,38 & 3,869 & 0,0420 & 2,72 & 3,144 & 0,0341 \\
m,p-Xileno & 3,96 & 4,697 & 0,0442 & 3,32 & 3,816 & 0,0359 \\
o-Xileno & 1,56 & 1,847 & 0,0170 & 1,28 & 1,501 & 0,0141 \\
\hline
\end{tabular}

A gasolina tipo C, além do etanol, tem a presença de benzeno, tolueno e xilenos, sendo que cada um desses compostos tem um comportamento característico. 0 benzeno é o composto com maior solubilidade, maior volatilidade, sendo também pouco persistente (facilmente degradável), além de altamente tóxico e carcinogênico (CETESB 2001a). 0 tolueno é pouco solúvel, menos volátil que o benzeno, mediamente persistente, e sua carcinogenecidade não é comprovada (CETESB 2001b). Os xilenos são pouco voláteis, pouco persistentes, pouco móveis, tóxicos e sua carcinogenecidade não é comprovada (CETESB 2001c). 
Tabela 4 - Características físico-químicas das gasolinas Tipo A e Tipo C, Benzeno, Tolueno, Xileno, Etilbenzeno e Álcool.

\begin{tabular}{|c|c|c|c|c|c|c|c|}
\hline Propriedade & $\begin{array}{l}\text { Gasolina } \\
\text { tipo A }\end{array}$ & $\begin{array}{l}\text { Gasolina } \\
\text { tipo C }\end{array}$ & Benzeno $^{(2)}$ & Tolueno $^{(2)}$ & Xileno $^{(2)}$ & Etilbenzeno $^{(4)}$ & Álcool ${ }^{(1)}$ \\
\hline $\begin{array}{l}\text { Natureza } \\
\text { química }\end{array}$ & Hidrocarbonetos & $\begin{array}{l}\text { Hidrocarbonetos } \\
\text { e álcool }\end{array}$ & $\begin{array}{c}\text { Hidrocarboneto } \\
\text { Aromático }\end{array}$ & $\begin{array}{c}\text { Hidrocarboneto } \\
\text { Aromático }\end{array}$ & $\begin{array}{c}\text { Hidrocarboneto } \\
\text { Aromático }\end{array}$ & $\begin{array}{c}\text { Hidrocarboneto } \\
\text { Aromático }\end{array}$ & Etanol \\
\hline Aparência & Liquido límpido & Liquido límpido & Liquido límpido & Liquido límpido & Liquido Límpido & $\begin{array}{l}\text { Liquido } \\
\text { Límpido }\end{array}$ & $\begin{array}{l}\text { Liquido } \\
\text { Límpido }\end{array}$ \\
\hline Cor & Amarelado & Amarelado & Incolor & Incolor & Incolor & Incolor & Incolor \\
\hline Odor & $\begin{array}{c}\text { Forte e } \\
\text { característico }\end{array}$ & $\begin{array}{c}\text { Forte e } \\
\text { característico }\end{array}$ & $\begin{array}{c}\text { Forte e } \\
\text { característico, } \\
\text { de gasolina }\end{array}$ & $\begin{array}{c}\text { Característico } \\
\text { relativamente } \\
\text { agradável }\end{array}$ & Característico & $\begin{array}{l}\text { Semelhante ao } \\
\text { da gasolina }\end{array}$ & Característico \\
\hline $\begin{array}{l}\text { Pressão de } \\
\text { vapor (kPa) }\end{array}$ & 58,8 & 79 & 13,33 & 5,33 & 1,33 & 1,33 & 12,7 \\
\hline $\begin{array}{c}\text { Densidade de } \\
\text { vapor }\end{array}$ & 4 & - & 2,7 & 3,18 & 3,7 & 3,66 & - \\
\hline $\begin{array}{l}\text { Densidade } \\
\left(\mathrm{g} / \mathrm{cm}^{3}\right)\end{array}$ & 0,75 & $0,73-0,77$ & 0,88 & 0,87 & 0,86 & 0,864 & 0,8093 \\
\hline $\begin{array}{l}\text { Solubilidade } \\
\text { em água }(\mathrm{g} / \mathrm{L})\end{array}$ & Desprezível & Insolúvel & 1,8 & 0,5 & 0,2 & 0,16 & Solúvel \\
\hline $\log P_{\text {ow }}$ & & $2,7^{(3)}$ & 2,13 & 2,65 & 3,12 & 3,15 & \\
\hline
\end{tabular}

(1)- FISPQ - Petrobrá

(2) - FISPQ - Merck

(3) - FISPQ -Petrosul

(4) - FISPQ - Innova

LE - Limite de Explosividade

LogP $\mathrm{P}_{\text {ow }}$ - Log da Partição Água Octanol 


\subsection{Interação de argilominerais esmectíticos com hidrocarbonetos}

Os argilominerais são importantes por sua abundância na crosta terrestre e suas inúmeras possibilidades de utilização pelo homem (Velde 1992). Algumas características dos argilominerais como o tamanho, a forma e a área superficial da partícula são relevantes do ponto de vista ambiental, pois influenciam diretamente suas interações com várias substâncias químicas. Em geral, o maior potencial para interação com poluentes está associado à maior área superficial apresentada por argilominerais de granulação muito fina, em detrimento daqueles com granulação mais grossa, e com forma de placa, ao invés de formas acicular (neddle) ou laminar (lath) (Figura 7).

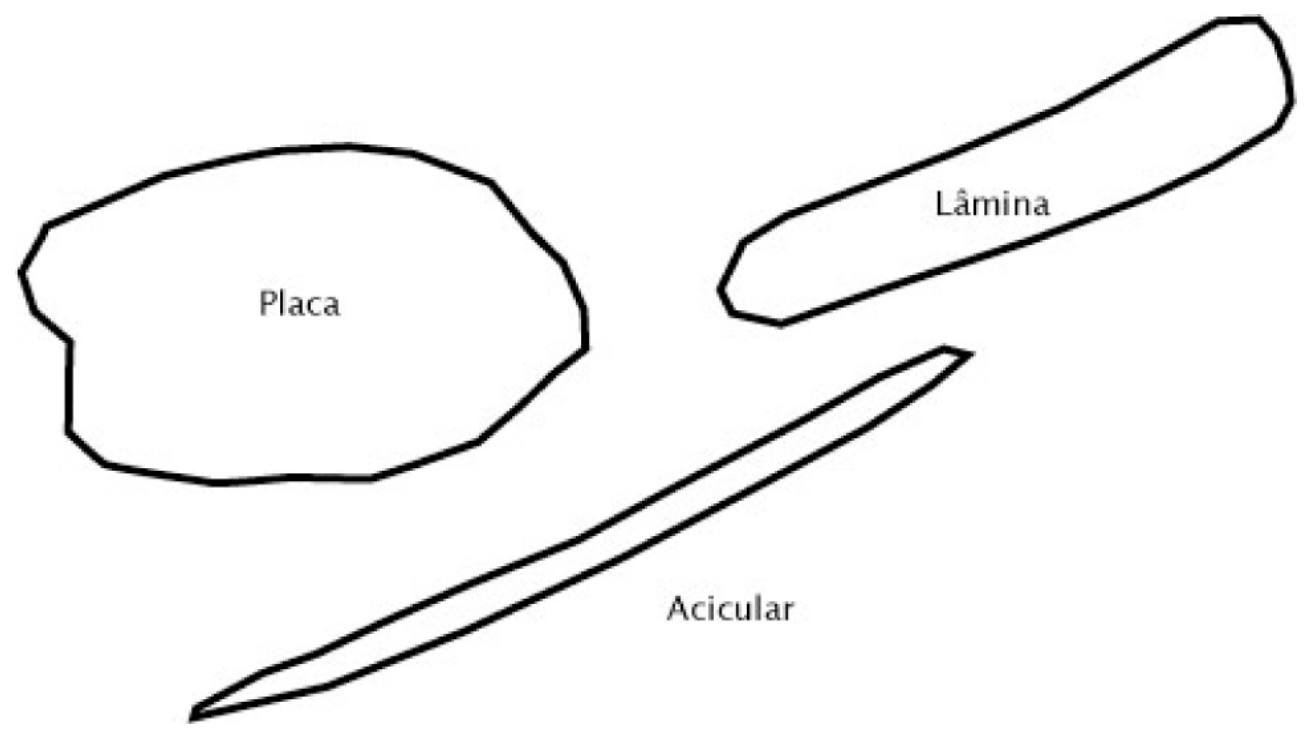

Figura 7 - Forma dos argilominerais (Velde, 1992)

No entanto, a propriedade mais importante dos argilominerais, notadamente dos esmectíticos, é a carga superficial, ou a atividade química de suas superfícies. Essa propriedade é devida a um déficit de carga nos argilominerais, causado por uma combinação de defeitos de crescimento, substituições catiônicas e quebras de ligações no retículo cristalino. 0 efeito é a produção de superfícies externas e internas carregadas negativamente (Velde 1995, Parker \& Rae 1998). Essas superfícies tendem a atrair íons e moléculas polares para equilibrar suas cargas, interagindo com diversas substâncias, que podem ser água, compostos orgânicos ou inorgânicos.

A interação é regida por processos de sorção. Sorção é um termo geral utilizado para descrever a forma pela qual um composto químico move-se de uma fase (por exemplo, líquida ou gasosa) e acumula-se em outra (por exemplo, uma fase sólida). A sorção de compostos geralmente depende de vários fatores, incluindo a composição química e iônica e o pH da solução, e a natureza química e preparação dos argilominerais (Parker \& Rae, 1998). Os processos pelos quais a sorção ocorre são chamados de adsorção e absorção, que são conjuntamente denominados de sorção e correspondem a (Santos 1989, Velde 1995) (Figura 8):

- adsorção - processo em que há a acumulação de espécies químicas em uma superfície, como a dos argilominerais;

- absorção - corresponde à incorporação de espécies químicas em uma outra fase, como a estrutura de um argilomineral. 


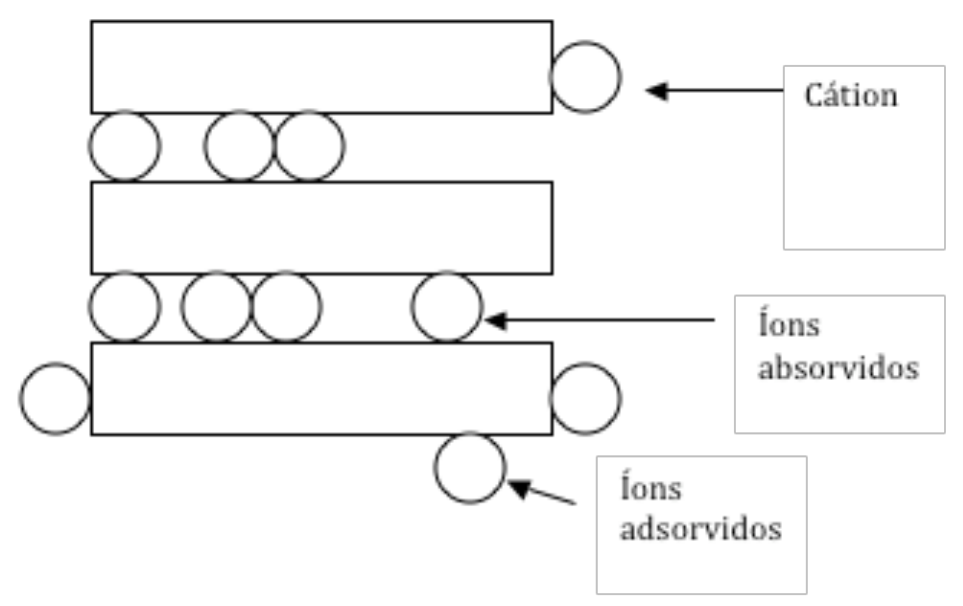

Figura 8 - Ilustração de mecanismos de sorção (Parker \& Rae 1998)

No ambiente, o principal efeito do déficit de carga nos argilominerais é relacionado à adsorção e absorção de espécies químicas, em muitos casos substâncias poluentes. São processos complexos que podem ser descritos como uma superfície carregada eletronegativamente e neutralizada por íons positivos oriundos, geralmente, de uma solução percolante. Os íons adsorvidos podem ser substituídos com relativa facilidade se há uma mudança na composição da solução, sendo mais raramente fortemente ligados à superfície da argila e dificilmente substituídos (Figura 9) (Parker \& Rae 1998).
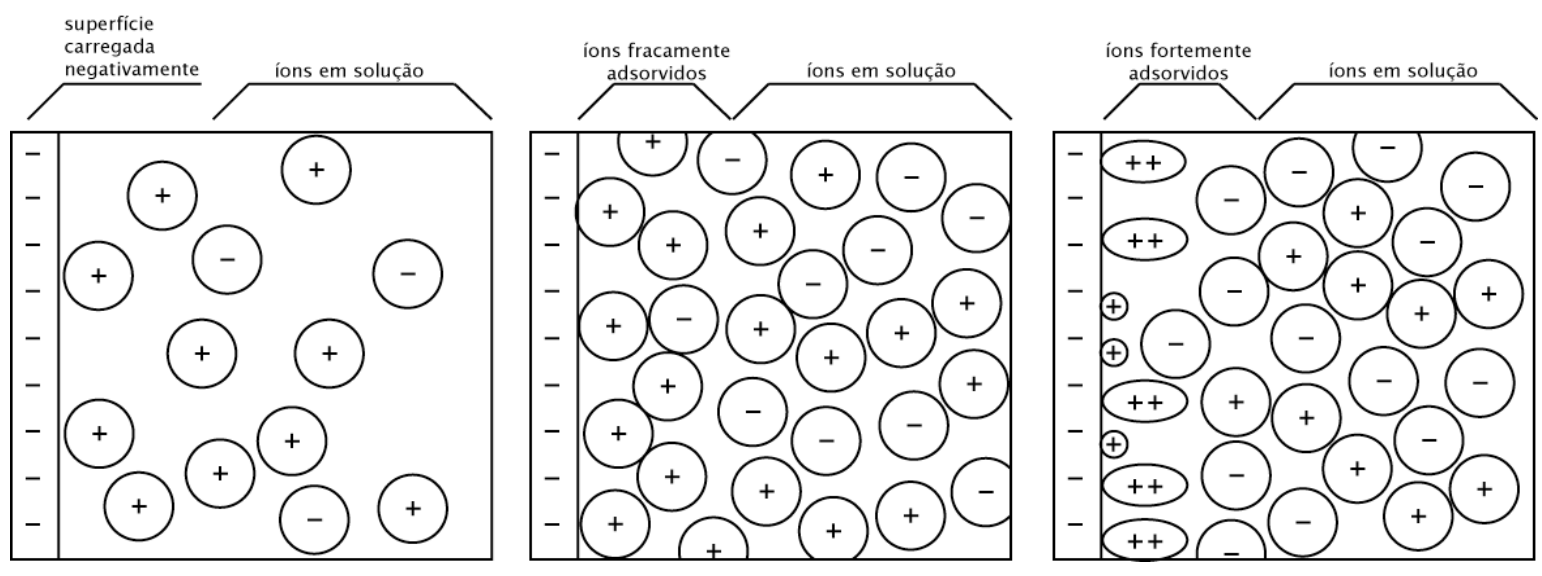

Figura 9 - Interação entre a superfície carregada negativamente dos argilominerais e íons em solução (Parker \& Rae 1998).

As substituições de átomos de Si nas folhas tetraédricas por átomos de $\mathrm{Al}$ ou de átomos de $\mathrm{Al}$ por $\mathrm{Mn}$, nas folhas octaédricas, são chamadas substituições isomórficas, já que não causam distorção da estrutura lamelar, por serem átomos de tamanhos similares. Essas substituições geram um excesso de carga negativa nas camadas dos argilominerais, que é compensada pela adsorção de cátions nas superfícies das camadas (Neumann 2000). Quando um líquido e seus íons dissolvidos entram em contato com os argilominerais, inicia-se a adsorção dos íons (Figura 10). A partir deste momento começam a ocorrer rearranjos em toda a estrutura, buscando o equilíbrio das cargas elétricas, levando os íons 
(ou moléculas) a ocuparem os espaços interlamelares, ou seja, sendo absorvidos. Esses processos produzem novas mudanças no sistema sólido-líquido, que busca continuamente o equilíbrio.

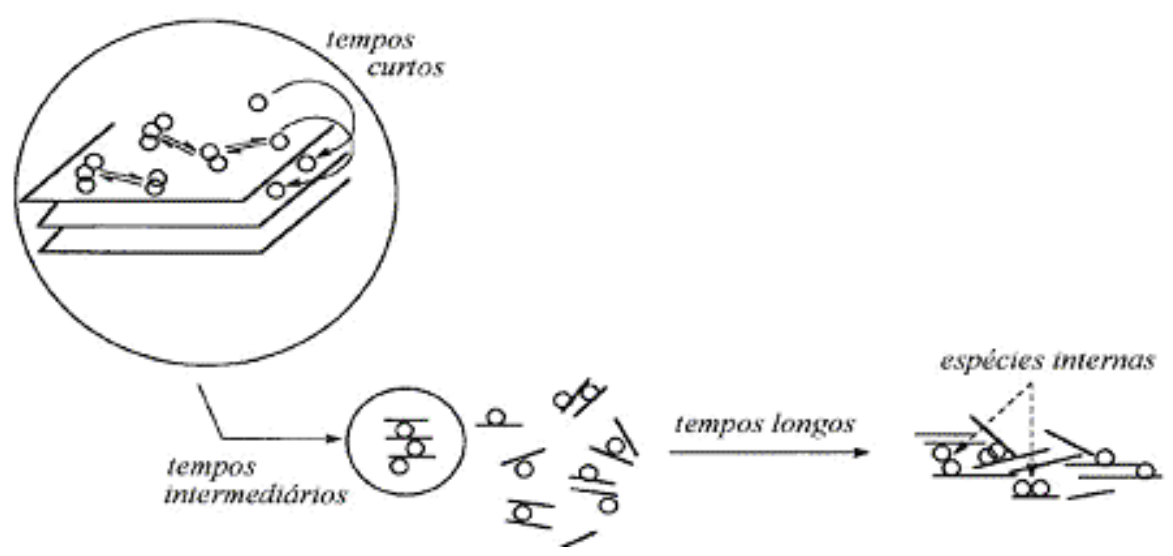

Figura 10- Tempos de interação determinam forma de sorção (Neumann 2000).

A absorção é uma característica importante dos argilominerais, que ocorre quando a distância interplanar basal se expande além do seu limite original, de cerca de $10 \AA$ nas espécies expansíveis (Figura 11), como resultado da absorção de moléculas nos espaços interlamelares, podendo atingir até $19,5 \AA$ em algumas esmectitas, mas comumente alcançando $15 \AA ̊$ com cálcio duplamente hidratado. Esse processo é também chamado de inchamento e decorre da presença de espaços negativos nos argilominerais, o que lhes dá a capacidade de reter íons trocáveis com vários níveis de hidratação, influenciando o inchar ou desinchar desses minerais (Velde 1995).
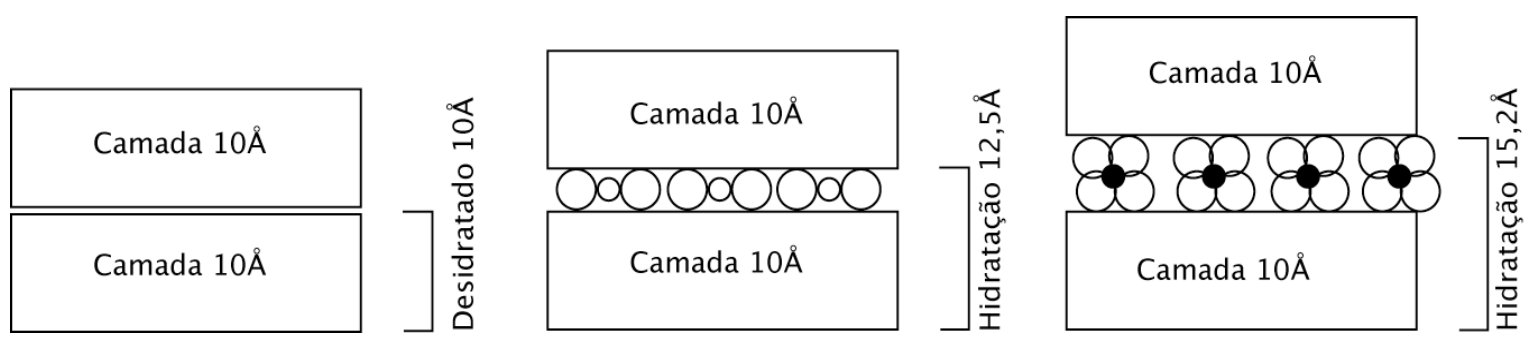

Figura 11- Mudança no espaçamento interlamelar da esmectita com a incorporação de moléculas absorvidas. A maior hidratação implica em um aumento do espaçamento (Velde 1995).

A capacidade de sorção de compostos é determinada pela capacidade de troca catiônica (CTC) dos argilominerais, que é diretamente relacionada ao $\mathrm{pH}$ e apresenta sua máxima sorbância em pH entre 1 e 5 (Parker \& Rae 1998). A CTC é uma propriedade que pode ser quantificada pelo número de moles possíveis de serem fixados em $100 \mathrm{~g}$ de argila seca (Santos 1989). Os argilominerais do grupo da esmectita possuem uma alta capacidade de troca catiônica, da ordem de 80a 150 meq/g (Velde 1995), sendo os argilominerais mais ativos química e fisicamente. A CTC de materiais ricos em argilominerais esmectíticos tem sido medida por um teste de desempenho de sorventes, normatizado pela American Society for Testing and Materials Standards (ASTM), onde diferentes sorventes são comparados (ASTM 2009). A Tabela 5 apresenta um teste de adsorção, onde diferentes hidrocarbonetos foram colocados em contato com bentonitas natural (de origem vulcânica) e experimental (expandida por tratamento em laboratório para servir como sorvente) (Pereira et al. 2005). Nota-se que as bentonitas naturais têm um 
comportamento bastante semelhante para a maioria dos produtos testados. Já as experimentais apresentam um grande incremento em sua capacidade de adsorver os compostos orgânicos, característica desejada para usos ambientais.

\begin{tabular}{|c|c|c|}
\hline \multirow{2}{*}{ Solvente } & \multicolumn{2}{|c|}{ Adsorção (hidrocarboneto/argila (g/g)) } \\
\hline & Bentonita Natural & Bentonita Experimental \\
\hline Gasolina & 2,12 & 8,90 \\
\hline Diesel & 2,16 & 3,57 \\
\hline Querosene & 2,22 & 3,20 \\
\hline Tolueno & 1,72 & 9,24 \\
\hline
\end{tabular}

Se a solução líquida em contato com a superfície carregada eletronegativamente do argilomineral tem uma variação na quantidade de íons dissolvidos, pode ocorrer um incremento no processo vigente, ou uma mudança no processo de sorção, ou ainda o processo de desorção, caso a solução se torne pobre em íons. Desorção é o processo inverso da sorção, com o material sendo liberado da fase sólida. Um dos fatores mais importantes controlando o transporte e o destino de produtos químicos em solos e sedimentos no ambiente natural é o processo de sorção-desorção (Parker \& Rae 1998).

Compostos orgânicos como a gasolina têm suas interações com os argilominerais regidas por mecanismos de adsorção e absorção (Parker \& Rae 1998). Segundo Velde (1992), quando moléculas em solução aquosa estão em contato direto com a superfície dos argilominerais, há uma competição onde moléculas de água são substituídas por partículas orgânicas, ou vice- versa, dependendo da concentração da solução e da neutralidade da superfície da argila. Grandes ou longas, as moléculas orgânicas podem ser diretamente incorporadas nas estruturas, entre camadas sem cátions. As moléculas orgânicas são fixadas por ligações van der Waals ou pontes de hidrogênio. Ambos os tipos de ligação permitem certa mobilidade das moléculas por terem pouca força de ligação. Moléculas orgânicas longas e lineares tendem a se posicionar paralela ou perpendicularmente às camadas (Figura 12), enquanto moléculas não lineares podem assumir outras orientações dependendo dos espaços livres.
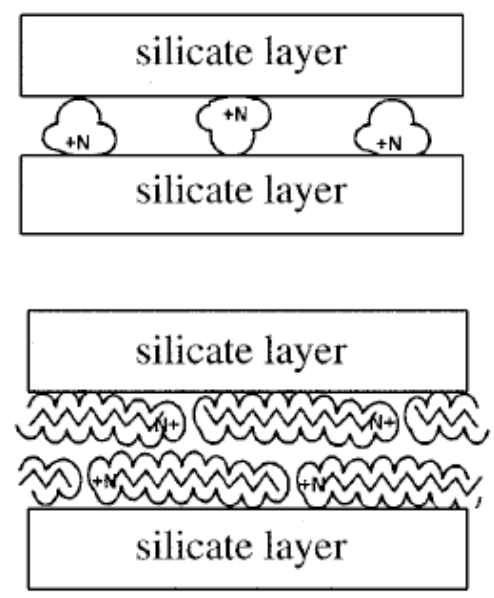

Figura 12- Moléculas lineares e não lineares incorporadas nos argilominerais (Sharmasarkar 2000).

Essa característica de interatividade com o meio em que se situa é inerente aos argilominerais e tem sido aproveitada, especialmente na remediação de locais impactados por hidrocarbonetos de petróleo e todos os seus derivados. 0 tratamento de locais 
contaminados por hidrocarbonetos de petróleo é um contexto ilimitado de aplicações de argilominerais esmectíticos. Podem ser aplicados em um pequeno posto de abastecimento, com pequeno volume de contaminantes, ou a um enorme complexo petrolífero, com uma grande gama de contaminantes no solo (Vianna 2004). Assim, a importância dos argilominerais nos trabalhos de recuperação ou proteção de áreas que podem sofrer degradação é cada vez mais evidente e estudada.

A contaminação da água subterrânea por hidrocarbonetos de petróleo pode ocorrer por pequenos vazamentos ou grandes rupturas dos tanques de armazenamento subterrâneo. Pode ocorrer também, por vazamentos nas bombas de abastecimento, nas linhas que ligam as bombas aos tanques, ou ainda durante a descarga dos combustíveis para os tanques (Smith 2003). Pequenos vazamentos podem ocorrer por longos períodos antes de serem detectados, e o grande tempo de contato com o solo pode permitir a absorção (Figura 10) e a dissolução dos produtos poluentes, solúveis em água, como benzeno, tolueno, e xilenos. A presença desses produtos no solo local permite também a liberação contínua desses contaminantes por longo período de tempo (Furtado 2005). A contaminação gerada é transportada pela água subterrânea, e seu impacto sobre os aqüíferos explotados é de grande importância. Em contrapartida, a contaminação gerada por grandes volumes de hidrocarbonetos pode resultar em uma fase líquida não aquosa (Non Aqueous Phase Liquid - NAPL), que pode migrar sobre a água subterrânea, na zona não saturada, contaminando amplas áreas. Argilominerais esmectíticos podem ser utilizados para ambos os tipos de contaminação, seja por uma fase diluída, seja por saturação do poluente. As características específicas de cada contaminante e argilomineral determinam sua maior ou menor eficácia.

Visando utilizações ambientais, há um grande número de trabalhos sobre pilarização e organofilização, tratamentos que incrementam as propriedades de interatividade, como expansibilidade e atividade química superficial, notadamente dos argilominerais do grupo das esmectitas (Leite et al. 2000, Pereira et al. 2005, entre outros). Nos Estados Unidos, argilominerais como esmectitas ou organobentonitas (nome comercial que denomina esmectitas modificadas para incrementar suas características de absorção) são utilizados para preencher as cavas onde serão instalados os sistemas de armazenamento subterrâneo de combustíveis (SASC) com a finalidade de minimizar quaisquer vazamentos que porventura venham a ocorrer nesses sistemas (Smith 2003). Organobentonitas são argilominerais organofílicos, ou seja, com afinidades para absorver componentes orgânicos, sendo sintetizados geralmente pela introdução de íons de quaternário de amônio entre as folhas dos argilominerais (Ruiz-Hitzky \& Meerbeek 2006). Geralmente argilominerais têm um comportamento que os faz inchar na presença de água e desinchar na presença de líquidos orgânicos não polares. Com o tratamento, as organobentonitas adquirem o comportamento inverso. Incham em presença de líquidos orgânicos não polares, e desincham na presença de água (Smith 2003). Atualmente, tanto no exterior quanto no Brasil há uma grande quantidade de pesquisas visando aprimorar as propriedades das organobentonitas, visando sua utilização em remediação de locais contaminados, por serem eficientes sorventes (Sharmasarkar 2000), ou ainda para utilização como material envoltório de preenchimento, em cavas de tanques de armazenamento subterrâneo (Smith 2003). 


\section{Materiais e métodos}

\subsection{Coleta de amostras}

A coleta de amostras da Formação Resende foi efetuada em três frentes de obras da Companhia do Metropolitano de São Paulo (Metrô), na região da Vila Prudente, zona leste da Cidade de São Paulo, onde está em execução a extensão da Linha 2-Verde do metrô (Ana Rosa - Vila Prudente) (Figura 13).

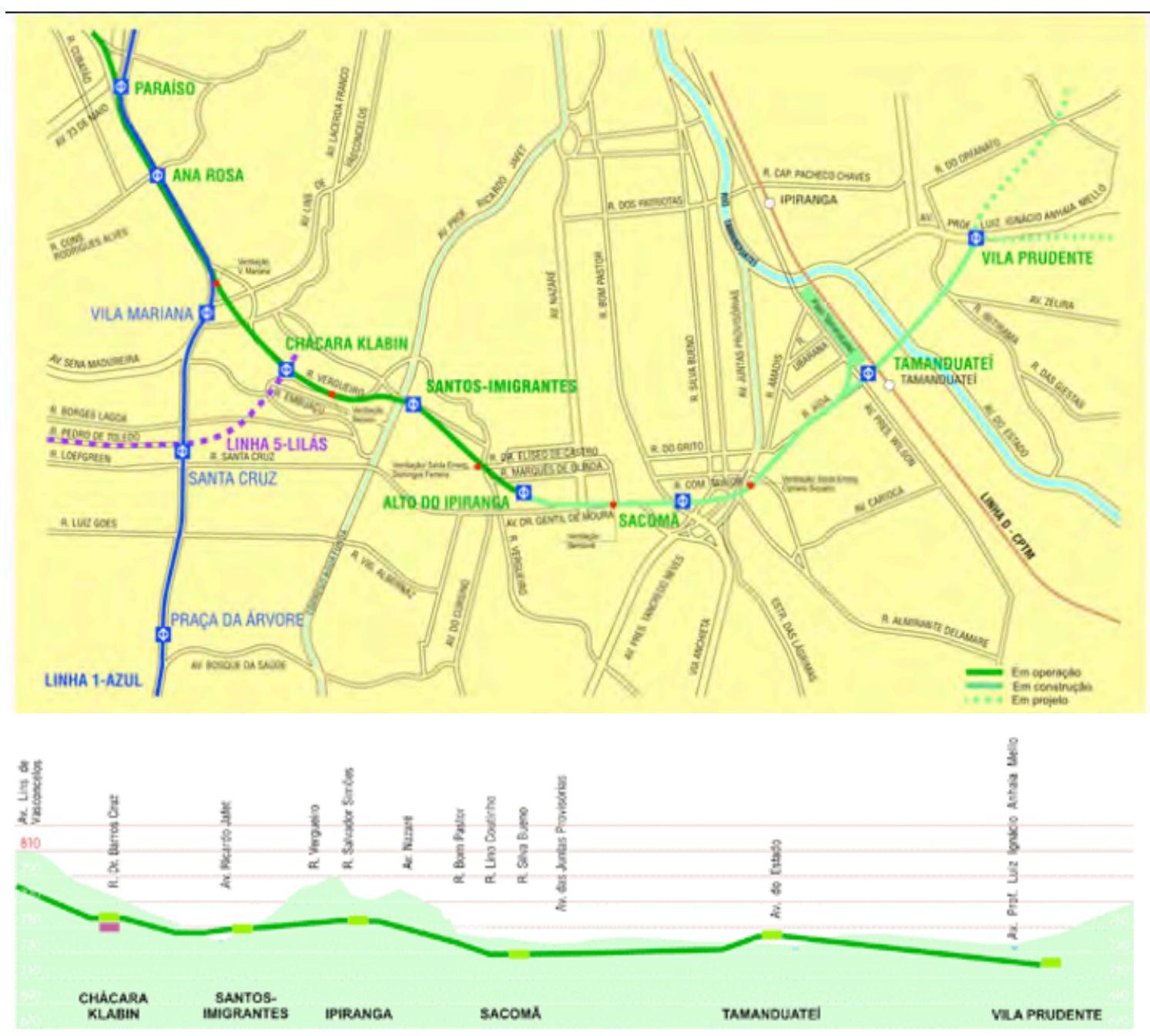

Figura 13 - Traçado da Linha 2-Verde (Ana Rosa - Vila Prudente) do Metrô (Metrô 2009).

Duas frentes de obras amostradas localizam-se no túnel de ligação entre as futuras estações Sacomã e Tamanduateí, uma nas proximidades da Rua Bom Pastor (Figura 14A) e outra na Avenida Junta Provisórias (Figura 14B). A terceira frente situa-se em poço de serviços na Rua Cavour (Figura 14C).

Nesses locais foram coletadas amostras de lamitos argilosos da Formação Resende, as quais foram denominadas Bom Pastor (BP), Juntas Provisórias (JP) e Cavour (CA), em alusão aos nomes das ruas de acesso às obras visitadas. Dentre as litologias da Fm. Resende, optou-se por coletar lamitos argilosos devido à abundância em argilominerais esmectíticos, o que facilitaria as etapas posteriores do estudo. A coleta dos lamitos em frentes de obras recém abertas permitiu a obtenção de amostras inalteradas (frescas) ou 
com pouca alteração. Na coleta, as amostras foram acondicionadas em sacos plásticos identificados e vedados para melhor conservação da umidade natural.

A Figura 15 apresenta os perfis geológicos dos locais de amostragem dos sedimentos da Formação Resende. Esses perfis foram elaborados a partir de dados de sondagens realizadas para as obras do Metrô. Os depósitos da Formação Resende compreendem camadas argilo-arenosas representativas da deposição de lamitos em porções distais de leques aluviais, que se intercalam a níveis arenosos de origem fluvial (Figura 16). Coberturas sedimentares de idade quaternária recobrem a Formação Resende e são sobrepostas por depósitos tecnogênicos. As amostras foram coletadas entre 20 e 25 metros de profundidade nas camadas lamosas.

Quando secos, os sedimentos apresentam cores distintas, sendo o lamito argiloso da Rua Bom Pastor de cor verde acinzentada, o lamito argiloso da Av. Juntas Provisórias de cor verde escuro acinzentado e o lamito argiloso da Rua Cavour de cor cinza. 0 sedimento da Rua Bom Pastor apresenta ainda planos de fraturamento encobertos por película de óxido de ferro de coloração amarronzada.

\subsection{Caracterização das amostras}

Previamente aos testes laboratoriais de interação dos argilominerais esmectíticos com hidrocarbonetos, foi realizada a caracterização das amostras de lamitos argilosos coletadas na Formação Resende, a partir de análises granulométrica, por difração de raios $\mathrm{X}$, microscopia eletrônica de varredura e química elementar CHN. Os procedimentos adotados em cada análise encontram-se descritos a seguir, destacando-se para cada uma delas a finalidade do seu emprego.

\subsubsection{Análise granulométrica}

Análises granulométricas foram realizadas para as amostras dos três locais amostrados na Bacia de São Paulo, visando a obtenção da distribuição do tamanho das partículas e classificação litológica dos sedimentos da Formação Resende, segundo Folk (1974). As análises foram realizadas via pipetagem e peneiramento, no Laboratório de Sedimentologia do Departamento de Geologia Sedimentar e Ambiental (GSA) do Instituto de Geociências da Universidade de São Paulo (IGc-USP), seguindo procedimentos rotineiros. A execução constou da secagem e desagregação do material, seguido da pipetagem de alíquotas de $10 \mathrm{ml}$ das frações silte e argila em tempos e profundidades prédeterminados, e posterior secagem e pesagem da massa de cada alíquota. Após a pipetagem, o material restante foi elutriado para eliminação da fração fina e obtenção das frações mais grossas (cascalho e areia) por peneiramento.

\subsubsection{Difração de raios $X$ - DRX}

A difração de raios $\mathrm{X}$ foi empregada para a caracterização mineralógica global dos sedimentos da Formação Resende, os quais foram analisados como rocha total e frações silte e argila, estas provenientes da preparação das amostras descrita no item 4.3.1. Para essas análises foi utilizado o Difratômetro Siemens D5000 instalado no Laboratório de Difração de Raios X do Departamento de Geotectônica e Mineralogia do IGc-USP, operando com radiação $\mathrm{CuK \alpha}, 40 \mathrm{kV}, 40 \mathrm{~mA}$, e goniômetro em condições rotineiras com passo de $0,02^{\circ}$ e tempo de contagem de 1 segundo. 


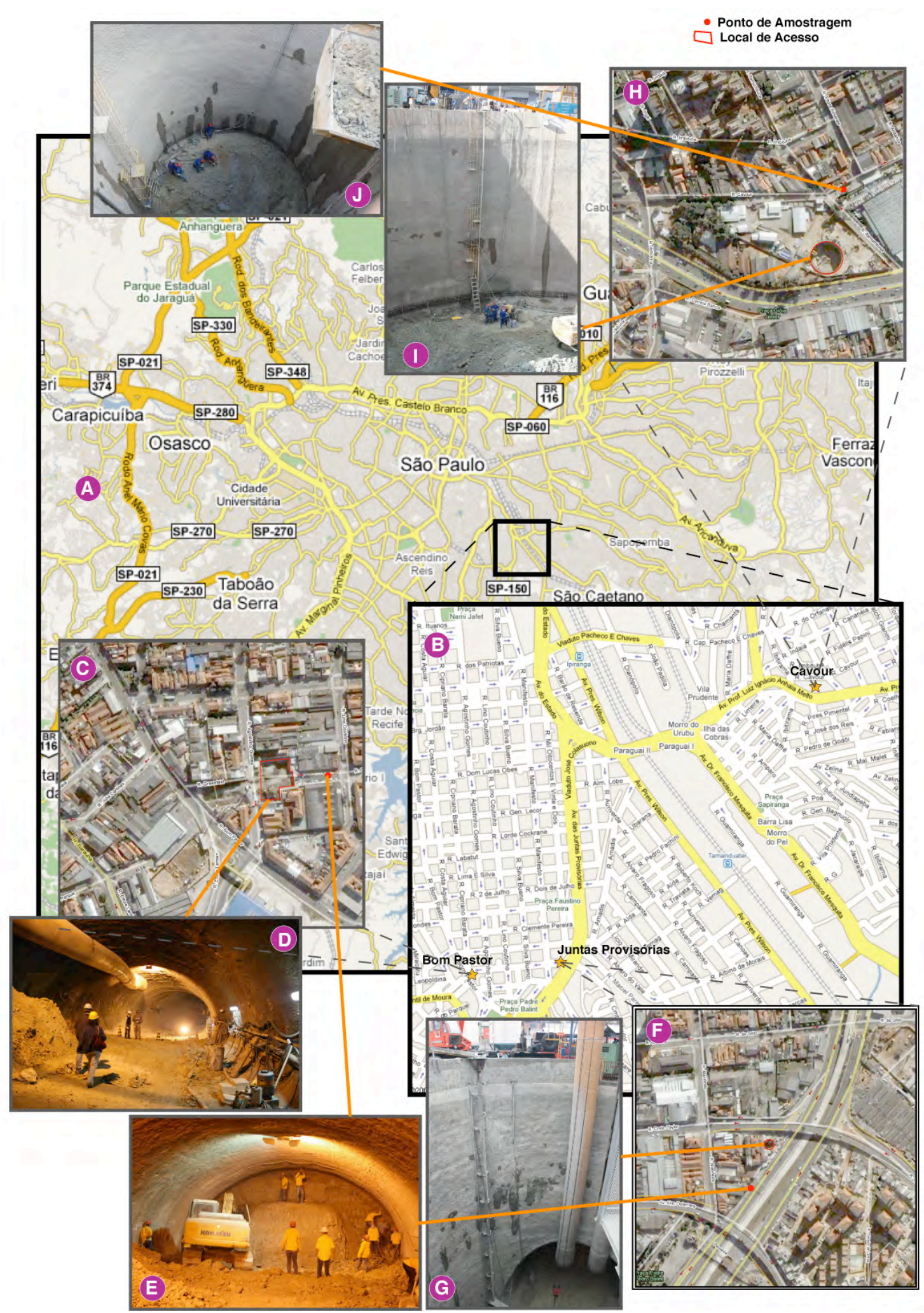

Figura 14- (A) Mapa com a localização da região amostrada na Bacia de São Paulo, na zona leste da Cidade de São Paulo. (B) Detalhe do mapa da figura anterior, com a localização das frentes de obras amostradas na Rua Bom Pastor, Avenida Juntas Provisórias e Rua Cavour. (C) Mapa do local de acesso à obra subterrânea na Rua Bom Pastor. (D) Foto do túnel subterrâneo escavado na Formação Resende, entre a Rua Bom Pastor e a Av. Juntas Provisórias. (E) Foto de frente de escavação na Formação Resende onde foi efetuada coleta de amostra. (F) Mapa do local de acesso à obra subterrânea na Av. Juntas Provisórias. (G) Foto do poço de acesso ao túnel subterrâneo sob a Av. Juntas Provisórias. (H) Mapa do local de acesso à obra subterrânea na Rua Cavour. (I) Foto de poço de emergência na futura estação Vila Prudente, nas proximidades da Rua Cavour, onde aflora a Formação Resende na base. (J) Foto do poço de serviços na Rua Cavour, onde aflora a Formação Resende na base e foi coletada amostra. 


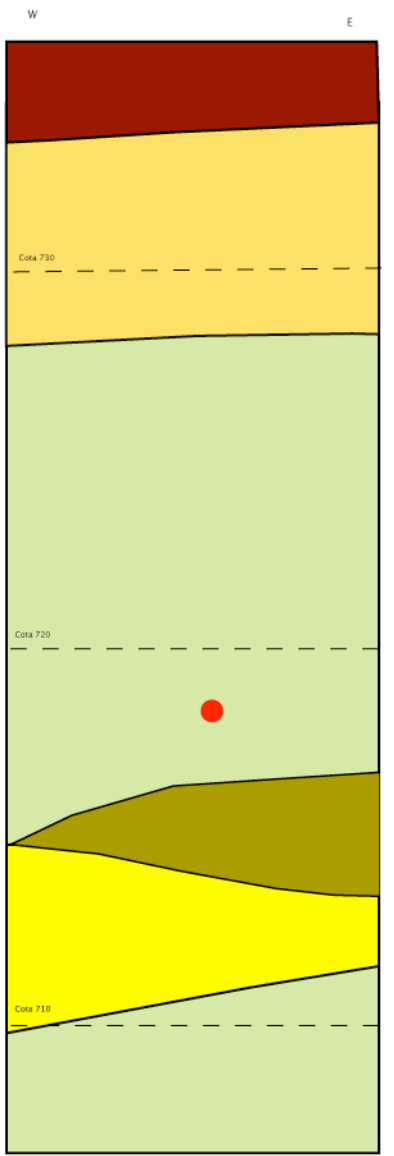

Perfil Bom Pastor

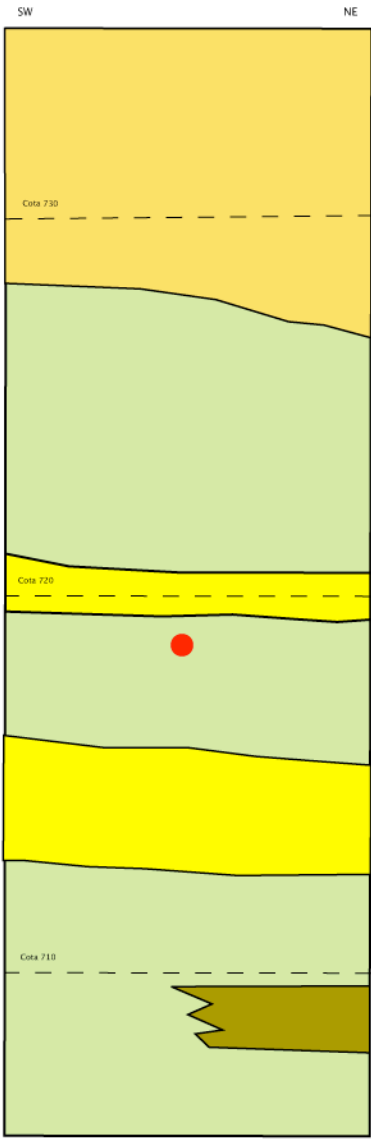

Perfil Juntas Provisórias

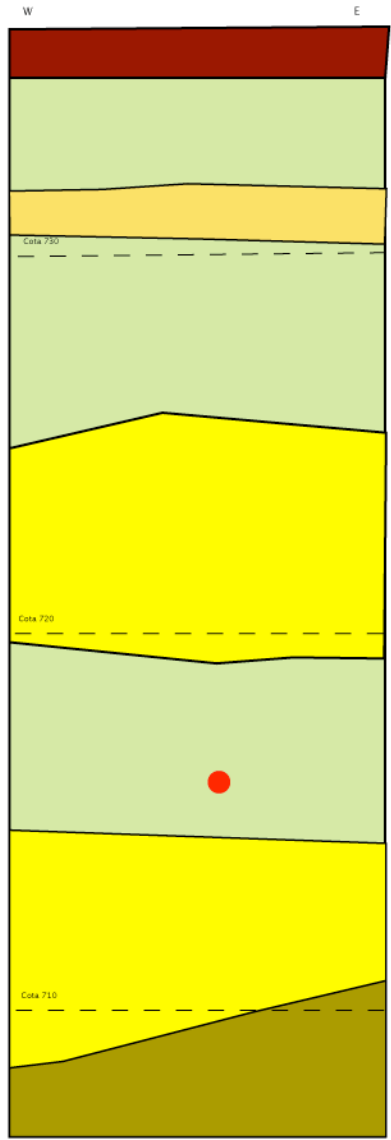

Perfil Cavour

Depósitos tecnogênicos

Depósitos aluvionares - Quaternário

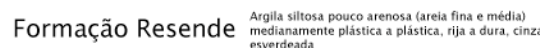

Formação Resende $\begin{gathered}\text { Argila arenosa (areia fina e média) pouco micáaea, } \\ \text { poucco a medianamente plástica, rija a dura, cinza. }\end{gathered}$

Formação Resende $\begin{gathered}\text { Areia média e grossa, pouco siltosa, medianamente } \\ \text { a muito compacta, cinza amarela. }\end{gathered}$

Ponto de amostragem

Figura 15 - Perfis geológicos da Formação Resende, com indicação do local de coleta de amostras.

A identificação mineralógica dos argilominerais foi realizada a partir de difratogramas de raios X das frações silte e argila, em seu estado natural (seca ao ar) e após tratamentos específicos como solvatação com etilenoglicol, por pelo menos 12 horas, e aquecimento a $490^{\circ} \mathrm{C}$ por 4 horas (e.g. Brindley \& Brown 1980, Moore \& Reynolds 1997).

Os resultados são apresentados em termos qualitativos para as espécies minerais identificadas. Para a interpretação e o tratamento gráfico dos difratogramas de raios $\mathrm{X}$ foi utilizado o software EVA, versão 1997, elaborado pela Siemens, contando com fichas de identificação do Joint Committee on Power Diffraction Standards (JCPDS). Os argilominerais foram identificados por comparação com difratogramas padrões disponíveis na literatura (e.g. Moore \& Reynolds 1997). 




Figura 16 - (A) Foto ilustrando frente de escavação na Formação Resende, onde foi efetuada coleta de amostra. (B) Detalhe de contato de camada de lamito e lente arenosa. (C) Detalhe de camada de lamito cinza amostrada. 


\subsubsection{Microscopia eletrônica de varredura - MEV}

Estudos por microscopia eletrônica de varredura com microanálise pontual por energia dispersiva acoplada (MEV/EDS) foram efetuados para a observação e obtenção de imagens da morfologia dos grãos individuais e da textura dos sedimentos, bem como a aquisição de dados químicos qualitativos para diferentes fases minerais. Para tanto, foi utilizado o microscópio eletrônico de varredura LE0440i do GSA do IGc-USP.

A preparação das amostras incluiu as etapas de secagem em estufa com temperatura controlada $\left(\sim 30^{\circ} \mathrm{C}\right)$, adesão de um fragmento de amostra indeformada com cerca de 3-5 mm sobre um suporte e metalização por carbono ou ouro.

\subsubsection{Análise elementar de carbono, hidrogênio e nitrogênio - CHN}

A análise química elementar de carbono total, hidrogênio e nitrogênio (CHN) foi empregada para a determinação dos teores desses elementos nas três amostras da Formação Resende coletadas na Bacia de São Paulo, as quais foram analisadas na forma de rocha total e frações silte e argila.

As determinações foram realizadas na Associação Brasileira de Cimento Portland (ABCP), sendo utilizado o analisador CHN 1000 marca LECO série 3082. Na metodologia utilizada, as amostras e suas duplicatas foram calcinadas a temperaturas superiores a $1.300^{\circ} \mathrm{C}$ e os gases provenientes dessa calcinação passaram através de detectores de infravermelho que quantificaram os elementos químicos carbono, hidrogênio e nitrogênio, sendo os resultados expressos em porcentagem de massa de CHN.

\subsection{Ensaios de sorção e desorção}

A interação de hidrocarbonetos com os argilominerais esmectíticos da Formação Resende foi estudada a partir de ensaios laboratoriais de sorção e desorção com as amostras de lamitos argilosos na forma de rocha total, fração silte $(<62 \mu \mathrm{m})$ e fração argila $(<2 \mu \mathrm{m})$, utilizando-se como contaminantes: gasolina comercial (tipo C), benzeno P.A., tolueno P.A. e xileno P.A. Esta interação foi estudada através de testes de absorção, adsorção e desorção, conforme descrito a seguir.

Para os ensaios de sorção e desorção, as amostras foram codificadas, de acordo com suas informações de origem, tipo de ensaio e contaminante empregado. A codificação gerou denominações do tipo XXYZWKKK, onde:

$[\mathrm{XX}]$ - refere-se ao local de coleta da amostra: BP - Bom Pastor, JP - Juntas Provisórias, CA - Cavour;

$[\mathrm{Y}]$ - nome do contaminante utilizado: $\mathrm{G}$ - gasolina, $\mathrm{B}$ - benzeno, $\mathrm{T}$ - tolueno, $\mathrm{X}$ - xileno;

[Z] - fração granulométrica analisada: T- rocha total, S - silte, A - argila;

[W] - tipo de ensaio realizado: S - sorção, D - desorção;

$[\mathrm{KKK}]-$ tempo de ensaio (ex.: $24 \mathrm{H}=24$ horas, $16 \mathrm{D}=16$ dias).

No total, foram ensaiadas 580 amostras e analisadas em laboratório para dosagem de BTEX 451 amostras (77\% do total preparado), sendo 247 amostras referentes aos testes de adsorção e 204 aos testes de desorção. Sete amostras adicionais foram ensaiadas para o teste de absorção. 


\subsubsection{Preparação das amostras}

Para os ensaios de sorção e desorção com rocha total dos lamitos da Formação Resende, as amostras foram inicialmente desagregadas manualmente em fragmentos com cerca de $3 \mathrm{~cm}$ e secas ao ar durante uma semana. Após a secagem, as amostras totais foram moídas em almofariz de ágata automatizado até passagem por peneira ABNT200 $(0,075 \mathrm{~mm})$. Para evitar a pulverização excessiva das amostras, toda a moagem foi realizada em ciclos de $15 \mathrm{~s}$, de modo que apenas cerca de $10 \%$ da massa total do material era passante na peneira de ABNT200, garantindo não haver excesso de moagem em cada ciclo.

As frações silte e argila dos lamitos da Formação Resende foram obtidas via pipetagem e centrifugação, segundo a Lei de Stokes. Primeiramente foi extraída a fração argila, a partir das seguintes etapas: 1) secagem das amostras totais em estufa com temperatura controlada a $45^{\circ} \mathrm{C} ; 2$ ) desagregação do material com água destilada, em almofariz de cerâmica com pistilo de borracha; 3) pipetagem e centrifugação da fração $<2 \mu$ m. Do material restante, com partículas essencialmente maiores do que $2 \mu \mathrm{m}$, foi pipetada e centrifugada a fração silte. As frações silte e argila, após centrifugadas, foram secas em estufa a $50^{\circ} \mathrm{C}$ por $48 \mathrm{~h}$ e posteriormente moídas em almofariz automático, até passagem em peneira ABNT200, garantido a homogeneização do material.

Alíquotas da rocha total e frações finas (silte e argila) de cada amostra de lamito foram destinadas à análise por difração de raios $\mathrm{X}$ descrita no item 4.2.2 e à dosagem dos teores de CHN (item 4.2.4), visando o controle mineralógico e do teor de matéria orgânica do material.

\subsubsection{Teste de inchamento}

Teste de inchamento foi efetuado para verificação de possível expansão interplanar dos argilominerais esmectíticos na interação com os hidrocarbonetos, o que indicaria absorção dos compostos orgânicos na estrutura.

Esse teste seguiu os procedimentos descritos por Pereira et al. (2005) e Vianna (2005), os quais são baseados no Standard Test Method for Swell Index of Clay Mineral Component of Geosynthetic Clay Liners (ASTM D 5890-95). Para tanto, alíquota de 1g de rocha total moída foi gradualmente adicionada a $50 \mathrm{ml}$ de líquidos orgânicos (gasolina comercial, benzeno P.A., tolueno P.A. e xileno P.A.) contidos em recipientes graduados de $100 \mathrm{ml}$, sem agitação, em temperatura ambiente. Após 24 horas, foram medidos os volumes das amostras nas colunas graduadas. As dispersões foram agitadas e novas medidas foram realizadas após 24 horas. Os resultados volumétricos foram registrados em $\mathrm{ml} / \mathrm{g}$.

Após os testes de inchamento, as amostras ensaiadas foram analisadas por difração de raios X para confirmação da existência ou não de qualquer expansão do espaçamento basal. Para tanto, utilizou-se o difratômetro Rigaku DMAX 11000, pertencente à Associação Brasileira de Cimento Portland (ABCP) e operando com radiação $\mathrm{CuK} \alpha, 40 \mathrm{kV}$, $20 \mathrm{~mA}$ e goniômetro com velocidade de $2^{\circ} 2 \theta$ /minuto.

\subsubsection{Teste de adsorção}

A capacidade de adsorção dos argilominerais foi determinada em função da granulação do sedimento (rocha total, frações silte e argila) e do tempo de contato entre a amostra e o contaminante (gasolina comercial tipo C, benzeno P.A., tolueno P.A. e xileno P.A.). Os intervalos de tempo de contato foram de 30 minutos, 2, 6, 18 e 24 horas, e 4, 16, e 32 dias (Figura 17). Esse teste objetivou poder traçar o comportamento de adsorção. A exposição da amostra ao contaminante foi realizada como segue: 
- $40 \mathrm{ml}$ do contaminante a ser testado foram colocados em uma proveta de $50 \mathrm{ml}$;

- a seguir, 4g do pó passante na malha \#200 ABNT de rocha total foram adicionados em porções de 0,1g ao contaminante, aguardando-se a deposição do material no fundo da proveta entre cada porção;

- a proveta foi completada com $10 \mathrm{ml}$ do líquido e lacrada.

0 procedimento foi repetido para as frações silte e argila.

Após o tempo de contato pré-determinado, a amostra foi retirada da seguinte forma:

- a proveta foi drenada de todo o líquido livre;

- a fase livre residual do produto foi eliminada, deixando-se a amostra 30 minutos em ambiente adequadamente ventilado;

- a amostra foi envasada e lacrada em frasco apropriado à dosagem do contaminante por cromatografia gasosa em laboratório analítico especializado. Após o envase e até a entrega da amostra no laboratório para análise por cromatografia, o frasco foi preservado do calor ambiente, para evitar a perda de material volátil.

\subsubsection{Teste de desorção}

A desorção dos contaminantes (gasolina comercial tipo C, benzeno P.A., tolueno P.A. e xileno P.A.) pelos argilominerais foi determinada também em função da granulação do sedimento (rocha total, frações silte e argila) e do tempo de exposição da amostra ao ar livre. Os intervalos de tempo foram de 30 minutos, 2, 6, 18 e 24 horas, e 4, 16, e 32 dias, seguindo o roteiro da Figura 17. Esse teste visou determinar o tempo necessário para a amostra desorver o contaminante e poder traçar o comportamento de desorção.
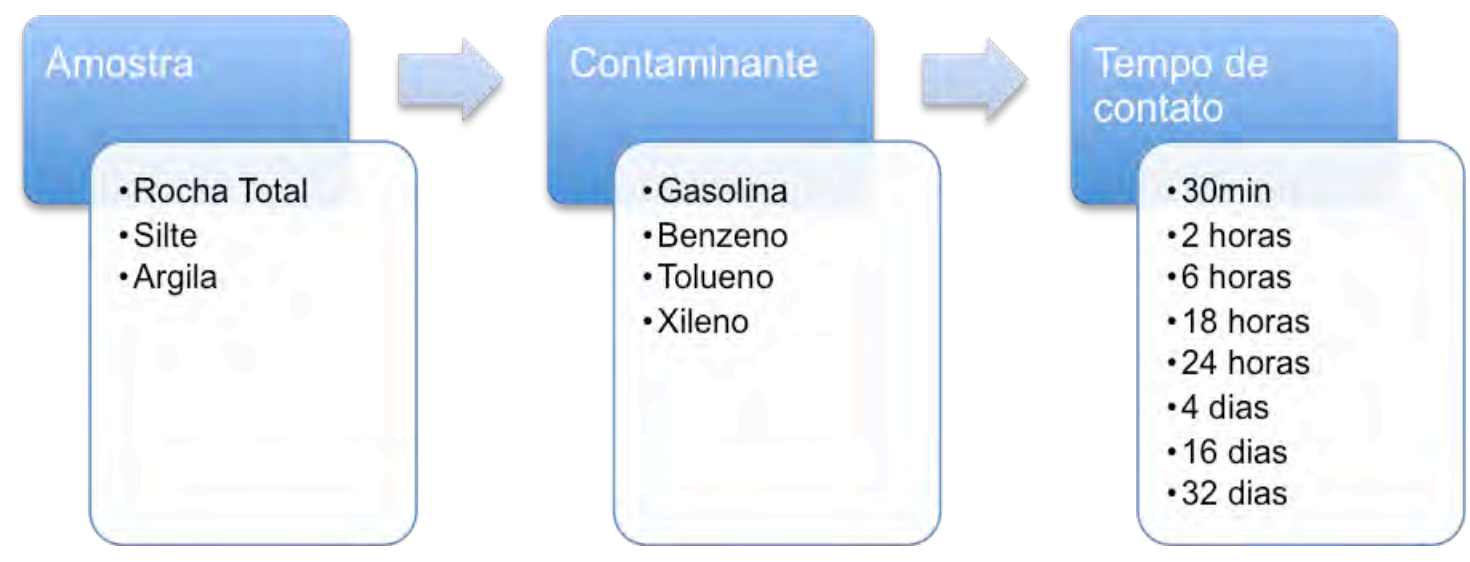

Figura 17 - Roteiro dos ensaios de adsorção e desorção.

Para este ensaio, a amostra foi previamente colocada em contato com o contaminante por $24 \mathrm{~h}$ para a interação entre eles. Com a amostra contaminada, o procedimento para desorção foi o seguinte:

- a proveta foi destampada e o líquido descartado;

- a amostra foi colocada em ambiente ventilado durante o tempo pré-determinado; 
- findo o período, a amostra foi envasada em frasco lacrado para análise por cromatografia gasosa em laboratório especializado. Após o envase e até a entrega da amostra no laboratório, o frasco foi preservado do calor ambiente, para evitar a perda de material volátil.

\subsubsection{Dosagem dos hidrocarbonetos}

A dosagem dos hidrocarbonetos das amostras ensaiadas foi efetuada por cromatografia gasosa no laboratório Analytical Solutions, utilizando-se detector de fotoionização, sendo esse um método empregado para determinar compostos orgânicos voláteis em uma variedade de matrizes. Os compostos foram analisados utilizando-se a técnica de headspace para injeção no equipamento. Um programa de temperatura é usado no cromatógrafo a gás para separar os compostos orgânicos. As identificações são obtidas analisando-se padrões sob as mesmas condições utilizadas nas amostras e comparando-se os tempos de retenção no cromatógrafo. Informação confirmatória é obtida com a comparação relativa de dois detectores. Concentrações dos compostos identificados são medidas pela resposta relativa do composto ao padrão interno (EPA 2009).

Para envio das amostras ao laboratório, foi criada uma numeração seqüencial, visando evitar a pronta identificação do tipo de contaminante utilizado, assegurando assim a qualidade dos resultados obtidos.

\section{Resultados da caracterização das amostras}

\subsection{Análise Granulométrica}

De acordo com a análise granulométrica realizada, a amostra de sedimento da Formação Resende proveniente da Rua Bom Pastor apresenta 94,84\% de materiais pelíticos, sendo $64,26 \%$ de argila e $30,58 \%$ de silte. Não há cascalho e os 5,26\% de massa de areia são distribuídos em $0,05 \%$ de areia muito grossa, $0,32 \%$ de areia grossa, 1,09\% de areia média, $1,89 \%$ de areia fina e $1,81 \%$ de areia muito fina (Figura 18). No diagrama de Folk (1974) (Figura 19), classifica-se como um argilito.
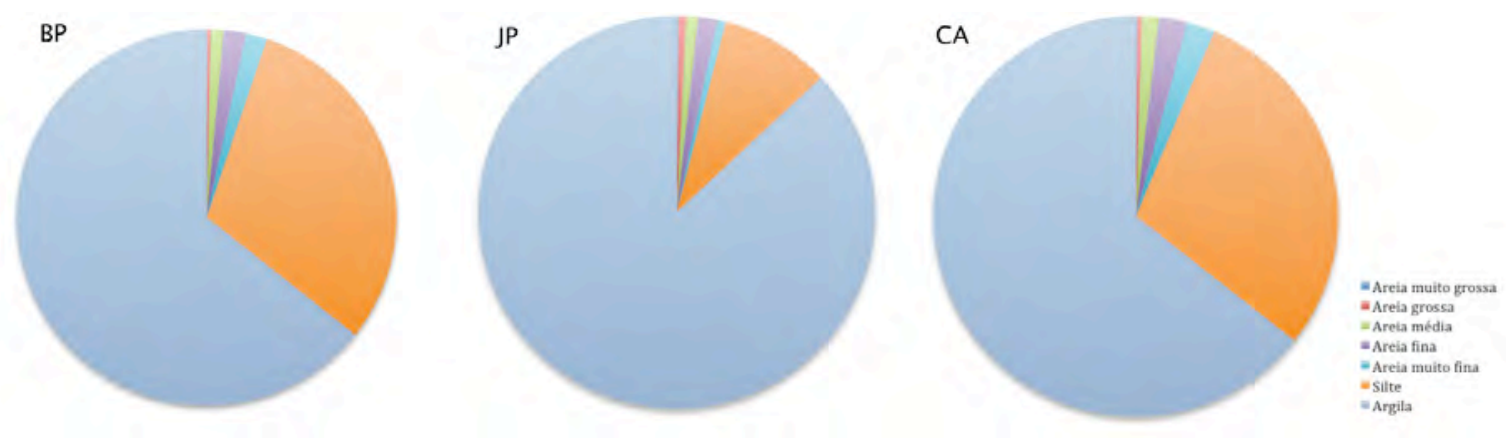

Figura 18 - Distribuições granulométricas das amostras da Formação Resende coletadas em frentes de obra na Rua Bom Pastor (BP), na Av. Juntas Provisória (JP) e na Rua Cavour (CA).

A amostra da Formação Resende coletada na Avenida Juntas Provisórias apresenta 96\% de materiais pelíticos, sendo $87 \%$ de argila e $9 \%$ de silte. Também não há cascalho e os $4 \%$ de massa correspondentes à fração areia são distribuídos em $0,14 \%$ de areia muito grossa, $0,63 \%$ de areia grossa, $0,97 \%$ de areia média, $1,54 \%$ de areia fina e $0,71 \%$ de areia 
muito fina (Figura 18). 0 resultado plotado no diagrama de Folk (1974) classifica o sedimento como um argilito (Figura 19).

O sedimento amostrado na Rua Cavour apresenta 93,67\% de massa de materiais pelíticos, sendo $64,32 \%$ de argila. Não há cascalho e os 5,26\% de massa de areia são distribuídos em $0,09 \%$ de areia muito grossa, 0,41\% de areia grossa, 1,33\% de areia média, $2,26 \%$ de areia fina e $2,25 \%$ de areia muito fina (Figura 18). Foi classificado também como argilito no diagrama de Folk (1974) (Figura 19).

Do ponto de vista do ambiente sedimentar da Formação Resende, esses sedimentos, classificados pela análise granulométrica como argilitos, são entendidos como lamitos argilosos, devido ao processo deposicional envolvido em sua gênese, quando da deposição dos leques aluviais distais por corridas de lama.

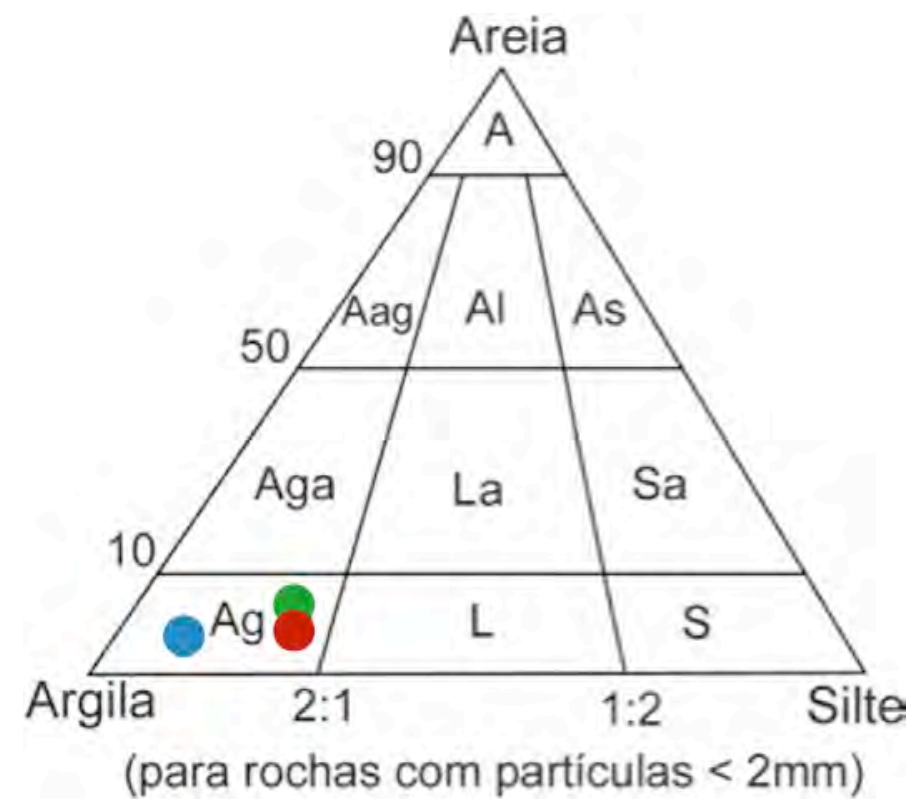

Figura 19 - Diagrama de Folk (1974), com a classificação de rochas sedimentares contendo misturas de areia e lama (argila e silte) e sem cascalho. As esferas coloridas representam a distribuição granulométrica das amostras analisadas (vermelho - Bom Pastor, azul - Juntas Provisórias, verde - Cavour). Legenda: A - arenito, Aag - arenito argiloso, Al - arenito lamoso, As - arenito siltoso, Aga - argilito arenoso, La - lamito arenoso, Sa - siltito arenoso, $\mathrm{Ag}$ - argilito, L - lamito, S - siltito.

\subsection{Difração de raios $X$}

Análises por difração de raios $\mathrm{X}$ foram realizadas para as três amostras coletadas na Bacia de São Paulo e visaram à caracterização mineralógica global dos sedimentos da Formação Resende. Os difratogramas de raios X obtidos são apresentados da Figura 20 à Figura 28. Nestes gráficos estão assinaladas as principais reflexões usadas na identificação dos minerais, sendo indicado o respectivo valor de $d$ em angstrom $(\AA ̊)$.

Nos difratogramas de rocha total, observa-se a presença de quartzo, principalmente nas

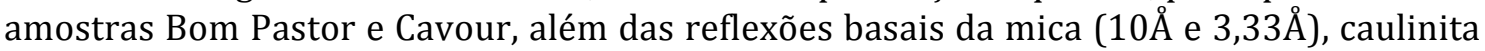
$(7,1 \AA ̊)$ e argilomineral esmectítico $(\sim 15 \AA ̊)$. As reflexões desses filossilicatos tornam-se mais intensas com a diminuição da granulação, indicando a concentração da fração argila a partir da preparação das amostras (item 4.3.1).

Caulinita (d001 = 7,1 $\mathrm{A}$ e $\mathrm{d} 002=3,57 \AA)$ e mica $(\mathrm{d} 001=10 \AA$ e $\mathrm{d} 002=3,3 \AA$ ) exibem reflexões basais em geral afiladas e com média a alta intensidade nos difratogramas das frações silte e argila naturais (secas ao ar) e solvatadas com etilenoglicol. As reflexões 
basais 001 e 002 da caulinita desapareceram após aquecimento, confirmando sua identificação, e a reflexão 001 da mica manteve-se em $10 \AA ̊$.

0 argilomineral esmectítico apresenta reflexão basal 001 variando de $15,6 \AA ̊$ a $16 \AA$, com intensidade média e perfil alargado, nos gráficos da fração argila natural. Esta reflexão expande para $17,1 \AA$ - $17,6 \AA$ após solvatação e contrai para $10 \AA$ após aquecimento, o que identifica a presença de esmectita. 0 perfil alargado da reflexão basal 001 sugere a presença de interestratificação desordenada de illita na estrutura do argilomineral, que, no entanto, contém grande proporção de esmectita (> 50\%), conforme sugere o valor de $17 \AA ̊$ da reflexão 001 após solvatação. Tendo em vista que as reflexões $002(\sim 8,5 \AA ⿱)$ e 003 $(\sim 5,6 \AA ̊)$ do argilomineral não se caracterizaram nos difratogramas das amostras solvatadas, dificultando a distinção precisa entre esmectita pura e interestratificado I/S, esse argilomineral será doravante denominado esmectítico, devido à sua alta proporção em esmectita, conforme indicado pelo seu comportamento expansivo.

Na Figura 29 são apresentados os gráficos de rocha total e frações finas das três amostras (BP, JP, CA) de modo que possam ser comparadas as áreas das reflexões basais 001 dos filossilicatos. De modo estritamente qualitativo pode-se apontar que a fração silte do argilito coletado na Av. Juntas Provisórias contém a maior proporção de argilomineral esmectítico, quando comparada à fração silte das amostras BP e CA, que parecem conter proporções semelhantes desse mineral (Figura 29B). Mica e caulinita ocorrem em maior quantidade no silte da amostra BP e em proporções sucessivamente menores nas amostras JP e CA. Argilomineral esmectítico parece ocorrer em maior quantidade na fração argila da amostra CA, seguida das amostras JP e BP, esta última com a menor quantidade (Figura 29C). Mica existe em proporções iguais na fração argila das amostras BP e CA e inferior na amostra JP. Caulinita apresenta-se enriquecida na argila da amostra BP e com quantidades iguais nas amostras JP e CA.

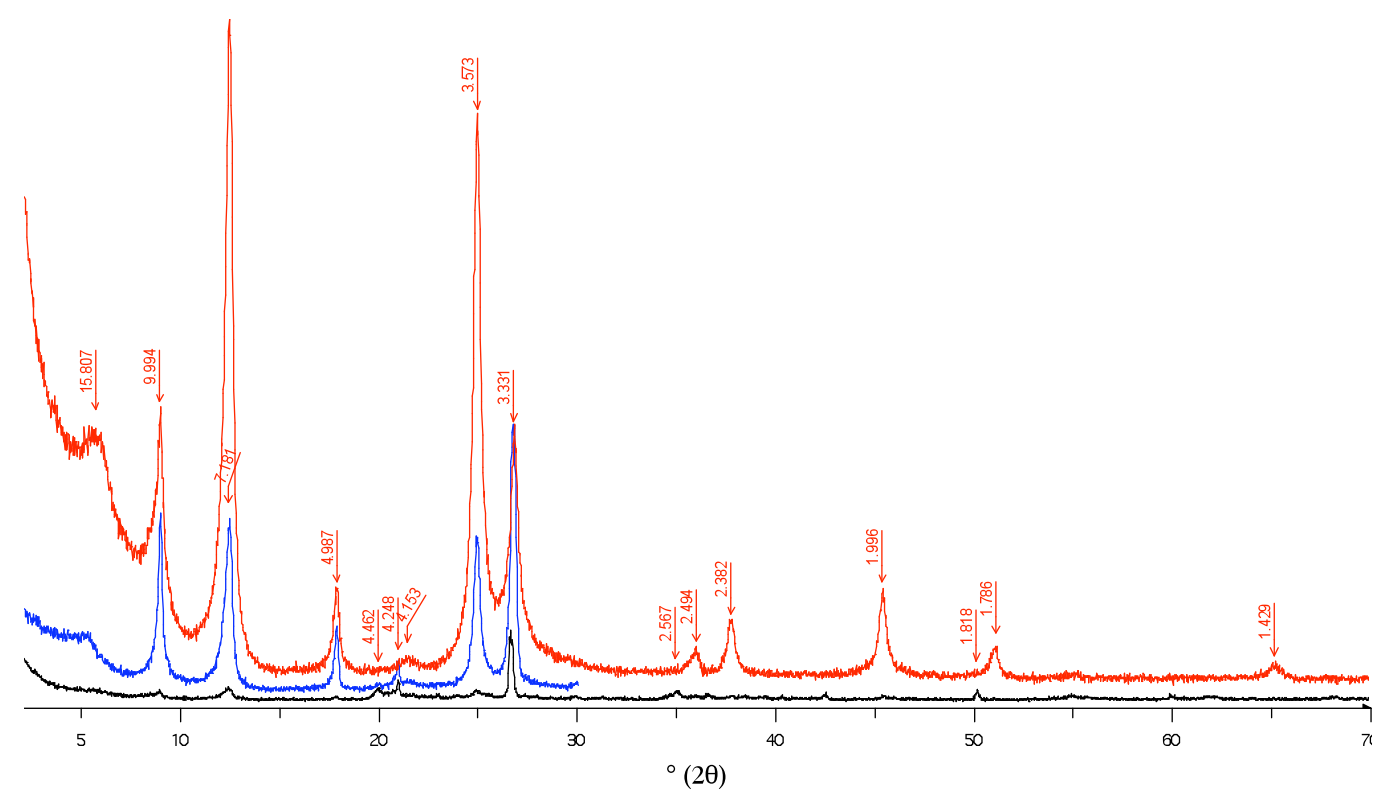

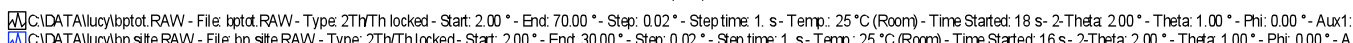

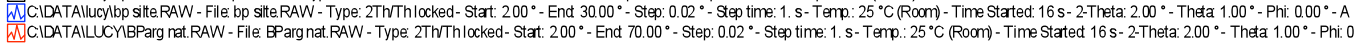

Figura 20 - Difratogramas de raios X do argilito coletado na Rua Bom Pastor. Legenda: gráfico preto - rocha total; gráfico azul - fração silte natural (seca ao ar); gráfico vermelho - fração argila natural (seca ao ar). 


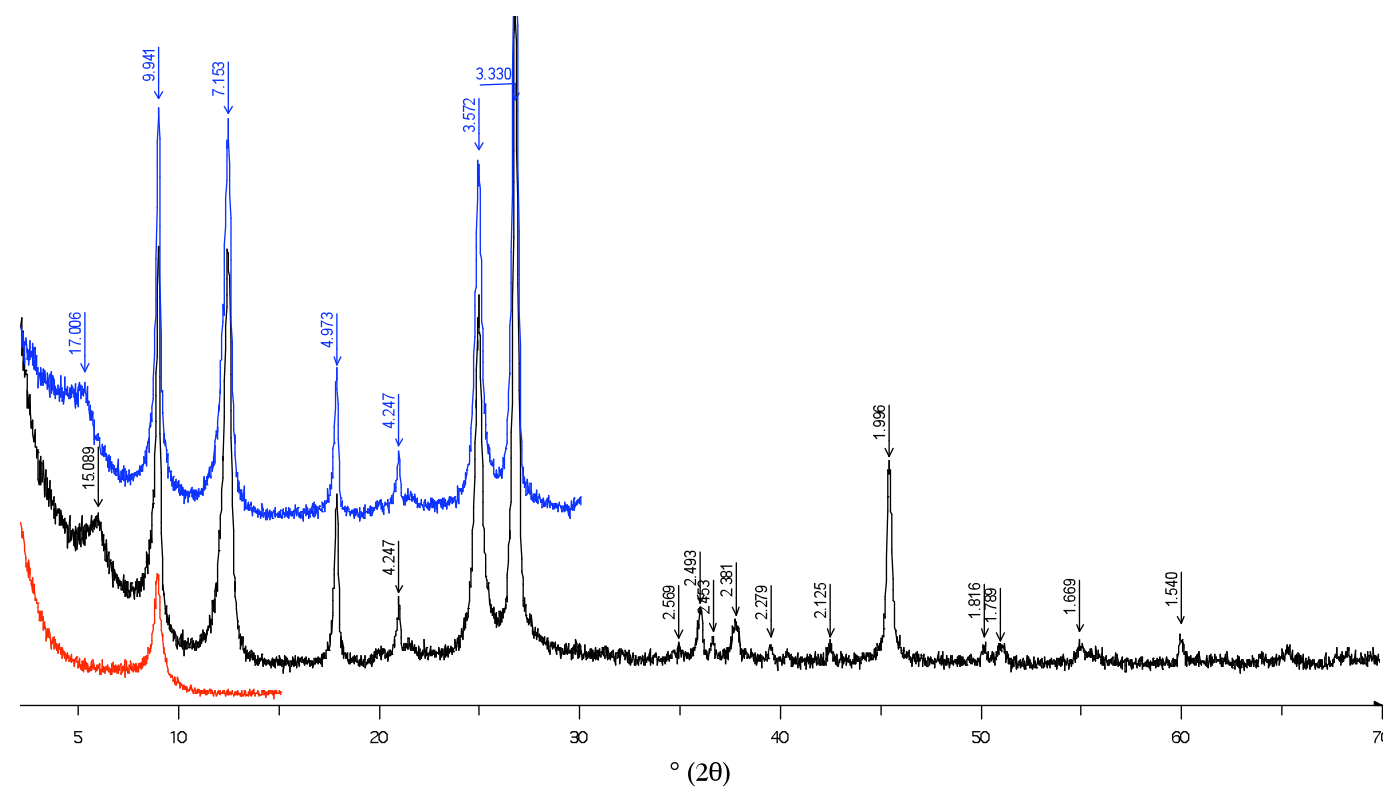

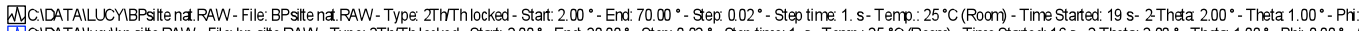

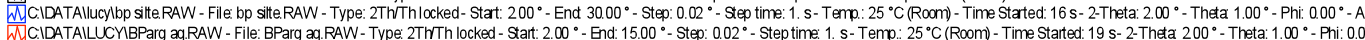

Figura 21- Difratogramas de raios X da fração silte do argilito coletado na Rua Bom Pastor. Legenda: gráfico preto - amostra natural (seca ao ar); gráfico azul - amostra solvatada; gráfico vermelho - amostra aquecida.

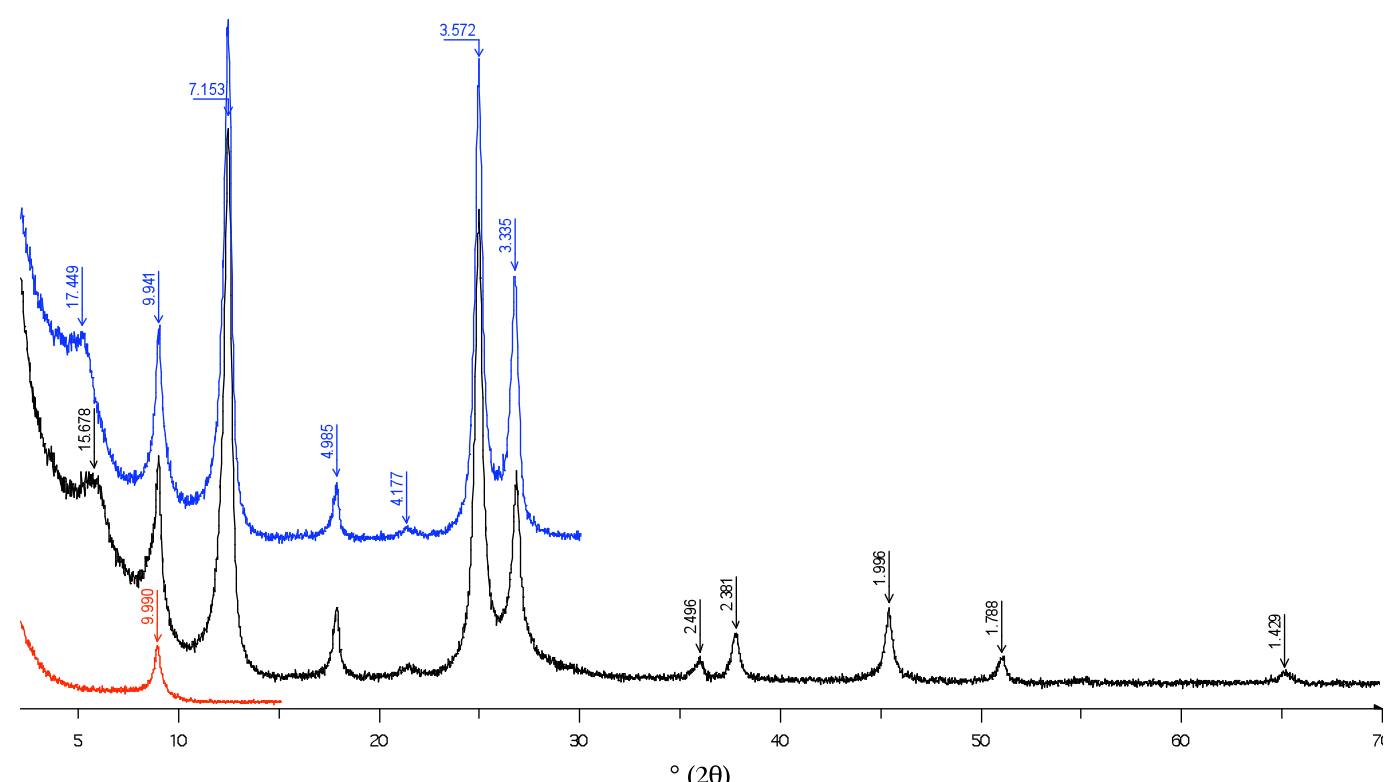

WCIDATALUCYCYBParg nat.RAW - File: BPargnat.RAW - Type: 2ThThlocked- Stat: $200^{\circ}$ - End $70.00^{\circ}$ - Step: $0.02^{\circ}$ - Step time: 1. S- Temp.: $25^{\circ} \mathrm{C}$ (Room) - Time Stated $16 \mathrm{~s}-2$-Theta: $2.00^{\circ}$ - Theta $1.00^{\circ}$ - Phi: 0

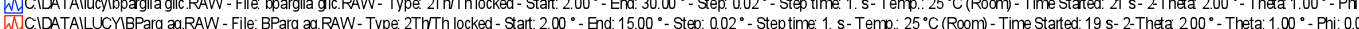

Figura 22- Difratogramas de raios X da fração argila do argilito coletado na Rua Bom Pastor. Legenda: gráfico preto - amostra natural; gráfico azul - amostra solvatada; gráfico vermelho - amostra aquecida. 


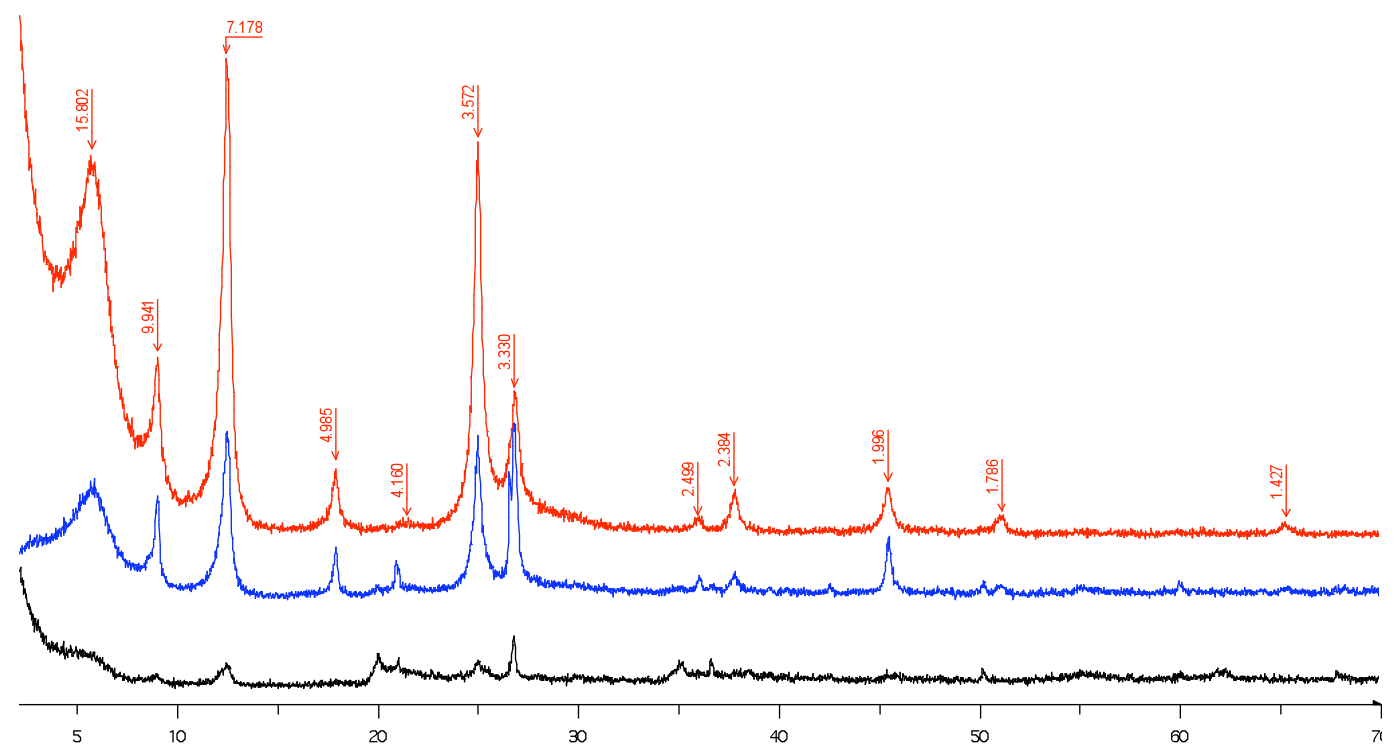

${ }^{\circ}(2 \theta)$

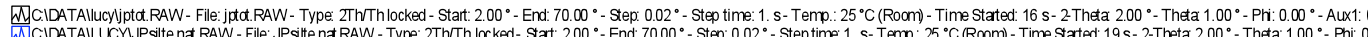

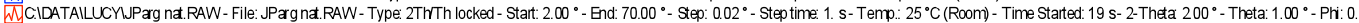

Figura 23 - Difratogramas de raios X do argilito coletado na Av. Juntas Provisórias. Legenda: gráfico preto rocha total; gráfico azul - fração silte natural; gráfico vermelho - fração argila natural.

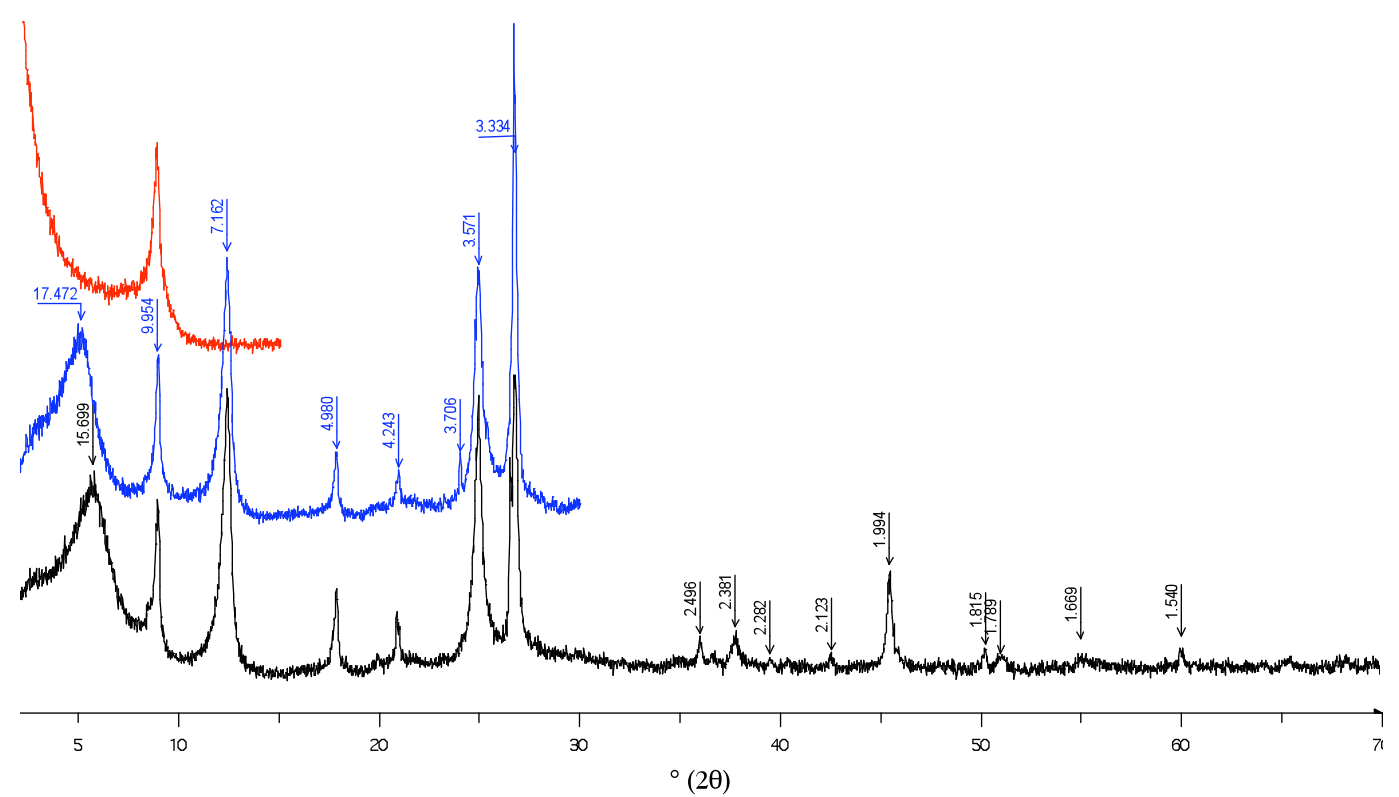

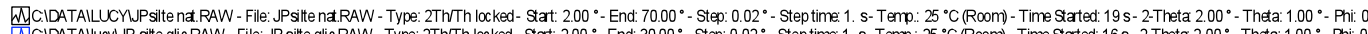

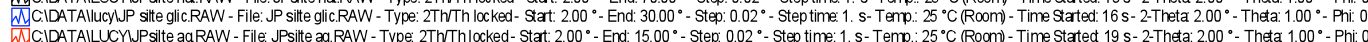

Figura 24 - Difratogramas de raios X da fração silte do argilito coletado na Av. Juntas Provisórias. Legenda: gráfico preto - amostra natural; gráfico azul - amostra solvatada; gráfico vermelho - amostra aquecida. 


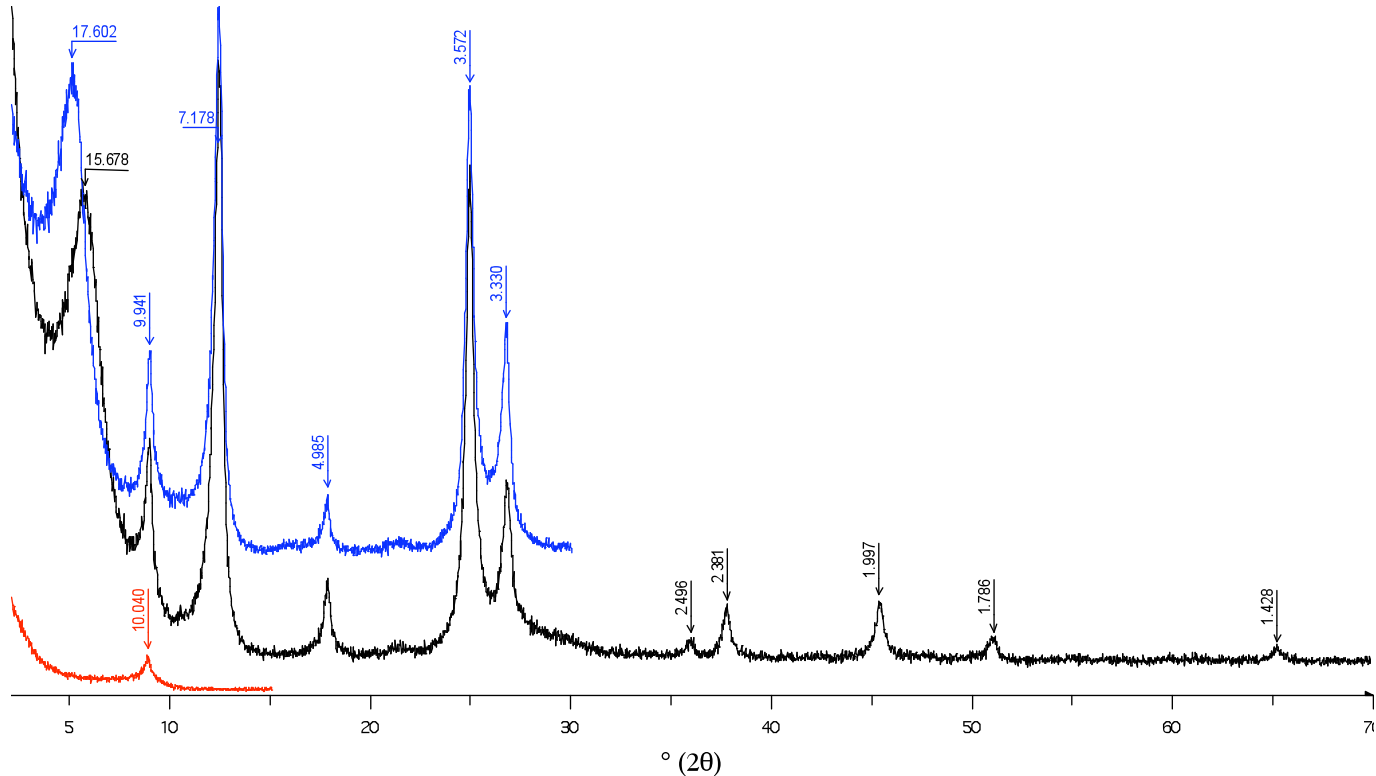

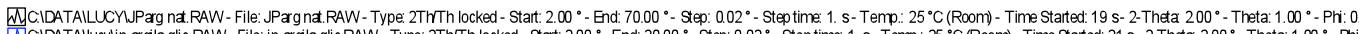

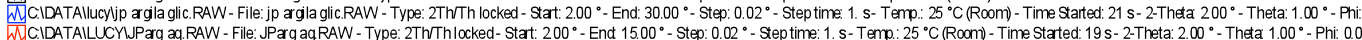

Figura 25 - Difratogramas de raios X da fração argila do argilito coletado na Av. Juntas Provisórias. Legenda: gráfico preto - amostra natural; gráfico azul - amostra solvatada; gráfico vermelho - amostra aquecida.

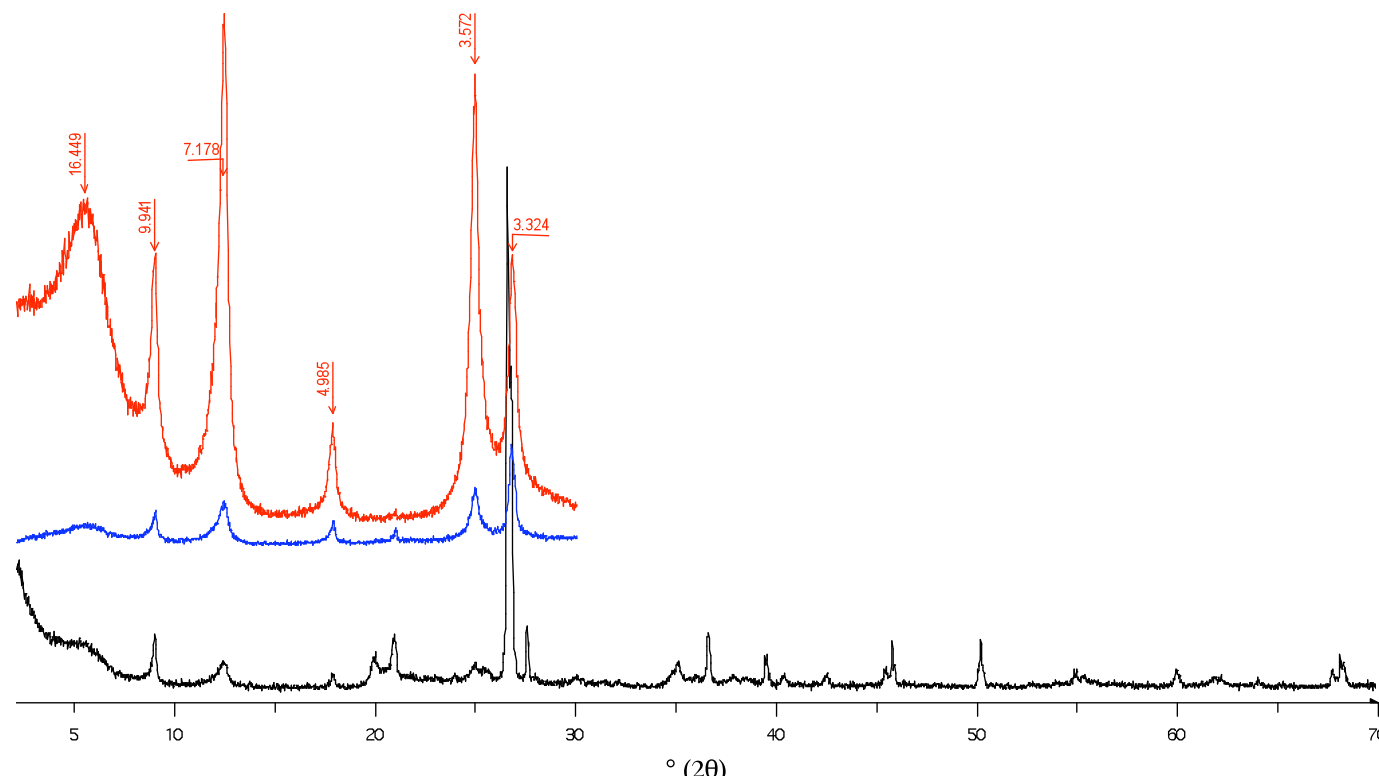

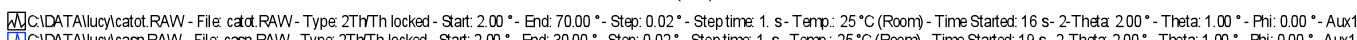

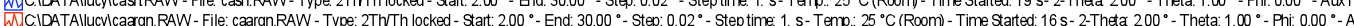

Figura 26- Difratogramas de raios X do argilito coletado na Rua Cavour. Legenda: gráfico preto - rocha total; gráfico azul - fração silte natural; gráfico vermelho - fração argila natural. 


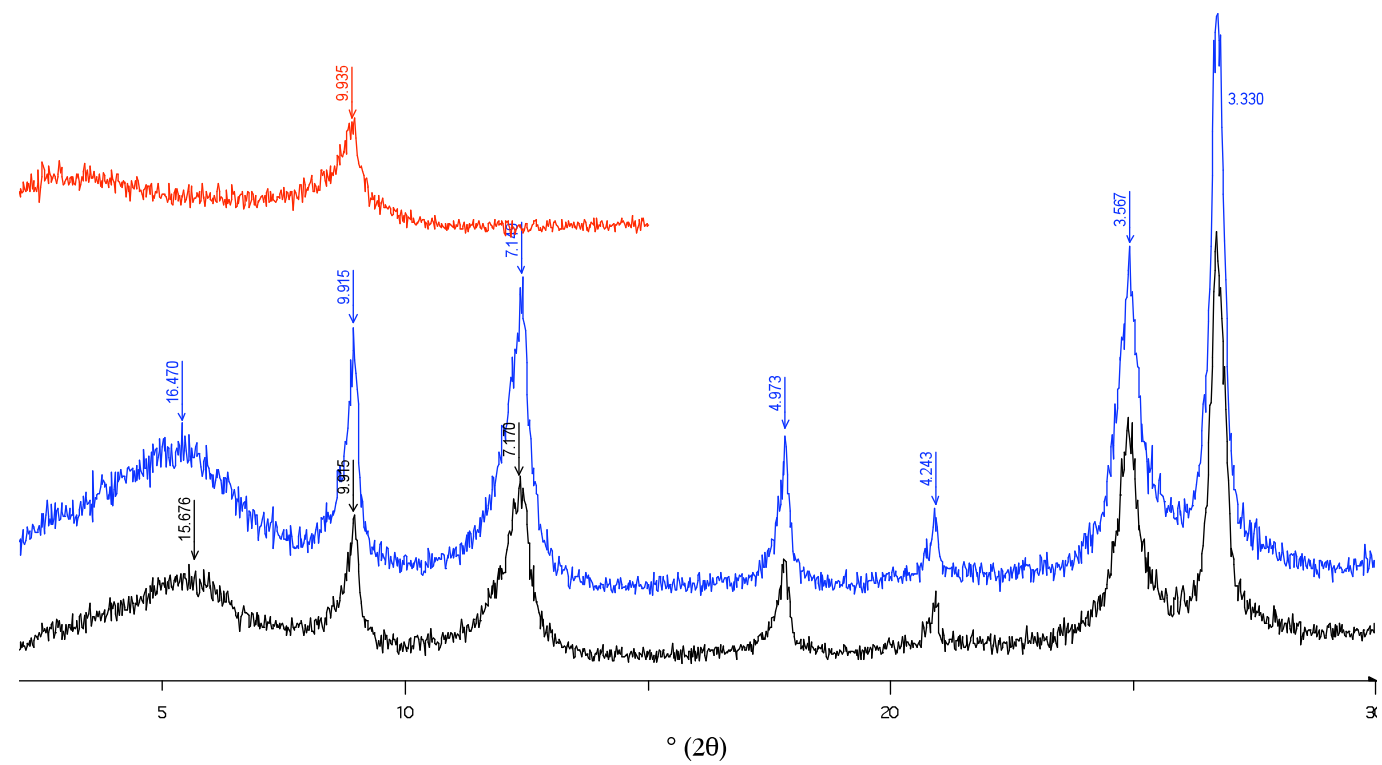

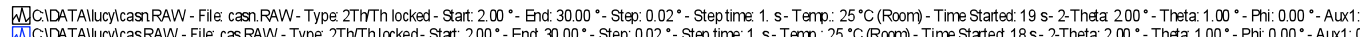

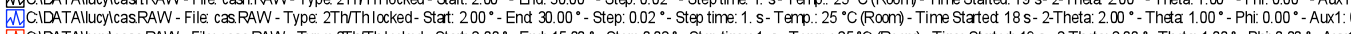
UT. IDATAllucylcasa RAW- File: casa RAW- Type: 2ThThlocked - Start: $2.00^{\circ}$ - End: $15.00^{\circ}$ - Step: $0.02^{\circ}$ - Step time: $1 . \mathrm{s}$ - Temp: $25^{\circ} \mathrm{C}$ (Room) - Time Stated: $19 \mathrm{~s}-2$ Theta: $2.00^{\circ}$ - Theta $1.00^{\circ}$ - Phi: $0.00^{\circ}$ - Aux

Figura 27 - Difratogramas de raios X da fração silte do argilito coletado na Rua Cavour. Legenda: gráfico preto amostra natural; gráfico azul - amostra solvatada; gráfico vermelho - amostra aquecida.

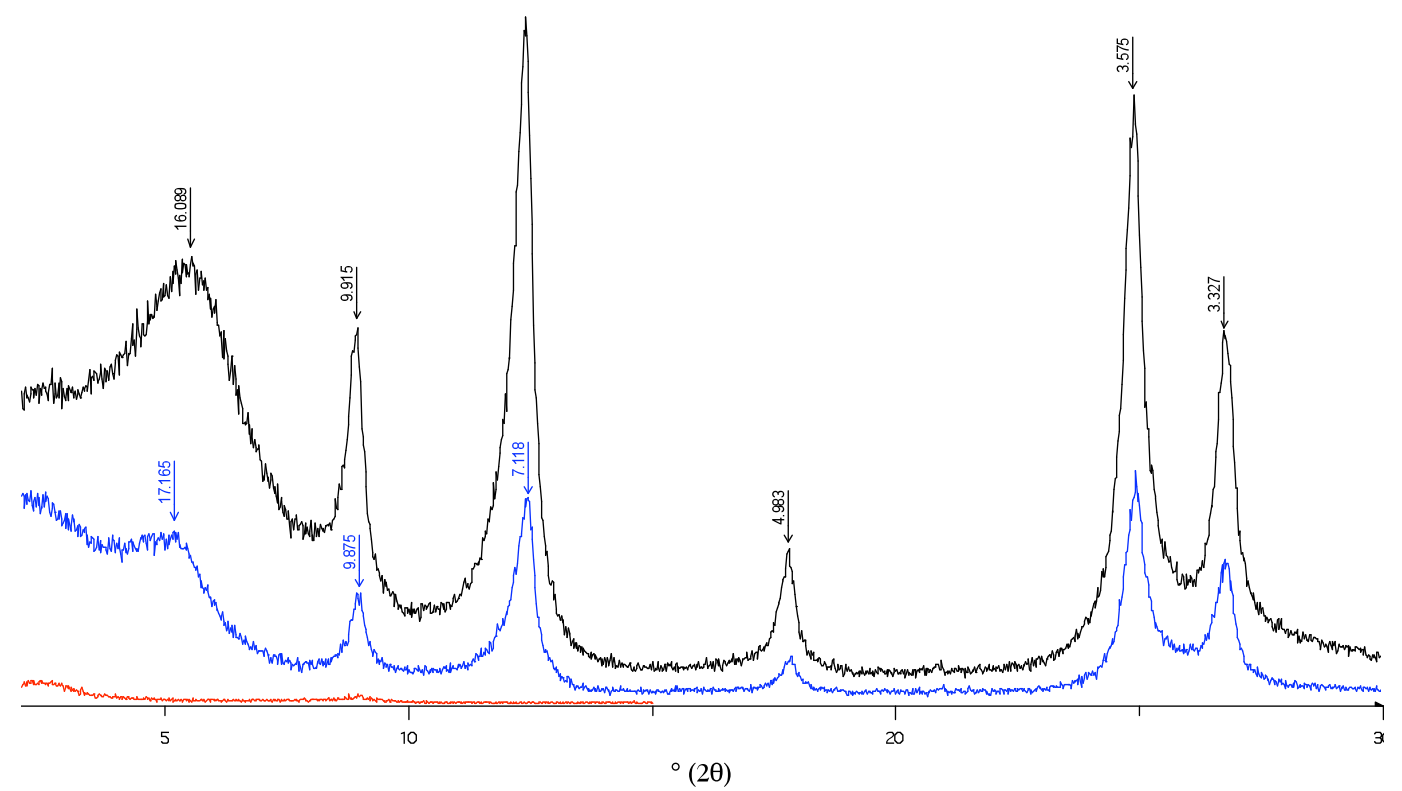

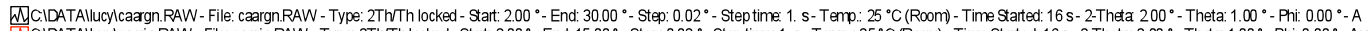

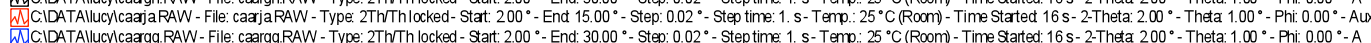

Figura 28 - Difratogramas de raios X da fração argila do argilito coletado na Rua Cavour. Legenda: gráfico preto - amostra natural; gráfico azul - amostra solvatada; gráfico vermelho - amostra aquecida. 

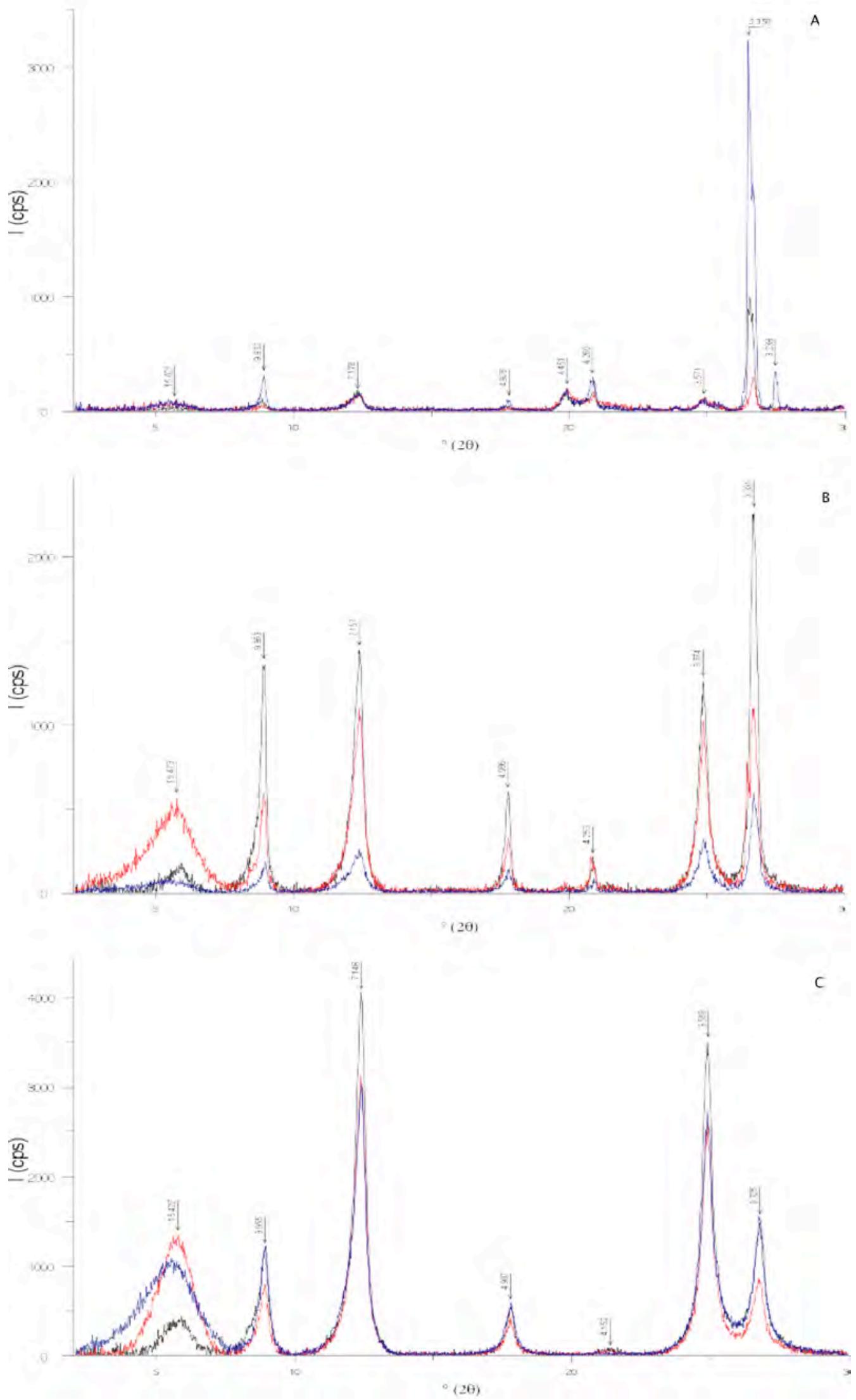

Figura 29 - Comparação entre os difratogramas de raios X de rocha total (A), fração silte (B) e fração argila (C) das amostras de argilito da Formação Resende. Legenda: gráfico preto - amostra coletada na Rua Bom Pastor; gráfico vermelho - amostra coletada na Av. Juntas Provisórias; gráfico azul - amostra coletada na Rua Cavour. 


\subsection{Microscopia eletrônica de varredura}

A Figura 30 exibe a textura do argilito da Formação Resende coletado na Rua Bom Pastor, onde pode ser observada sua granulometria variada, com clastos de mica e quartzo distribuídos aleatoriamente na matriz, composta por argilominerais com forma de placa arredondada. Lepisferas de sílica foram também observadas preenchendo a porosidade na borda de grãos de silte e resultam da percolação de soluções, de provável natureza hidrotermal, à época de deposição da Formação Resende (Sant'Anna \& Riccomini 2001).

O argilito da Formação Resende amostrado na Rua Juntas Provisórias (Figura 31) apresenta estrutura maciça e é composto por matriz argilosa detrítica contendo grãos de quartzo angulosos, com granulação silte. As placas de argilominerais constituintes da matriz possuem bordas corroídas, que evidenciam sua origem detrítica e seu desgaste por quebra durante o transporte da área fonte até o sítio deposicional.

0 argilito da Rua Cavour (Figura 32) apresenta-se com aspecto bastante homogêneo e estrutura maciça, sendo composto por argilominerais com formas arredondadas.

\subsection{Análise elementar de carbono, hidrogênio e nitrogênio}

Os resultados obtidos na determinação dos teores de carbono, hidrogênio e nitrogênio (CHN) das amostras da Formação Resende, na forma de rocha total e frações finas, são apresentados na Tabela 6. Os teores de CN em solos e sedimentos são normalmente oriundos de material orgânico particulado, que no caso das amostras da Formação Resende estaria presente em pequena proporção, conforme indicam os baixos conteúdos de carbono $(0,2$ a $0,37 \%)$. Os teores mais elevados de hidrogênio $(0,72$ a 1,79\%) podem atribuídos à água estrutural dos argilominerais e óxidos de ferro hidratados, além de material orgânico.

Tabela 6 - Resultados das análises de CHN (\% em massa).

\begin{tabular}{cccc}
\hline Amostra & Carbono & Hidrogênio & Nitrogênio \\
\hline BP-T & 0,28 & 1,19 & ND \\
BP-S & 0,2 & 0,72 & ND \\
BP-A & 0,28 & 1,65 & ND \\
JP-T & 0,37 & 1,63 & ND \\
JP-S & 0,25 & 1,5 & ND \\
JP-A & 0,32 & 1,79 & ND \\
CA-T & 0,21 & 1,1 & ND \\
CA-S & 0,28 & 0,79 & ND \\
\hline
\end{tabular}

ND - não detectado 

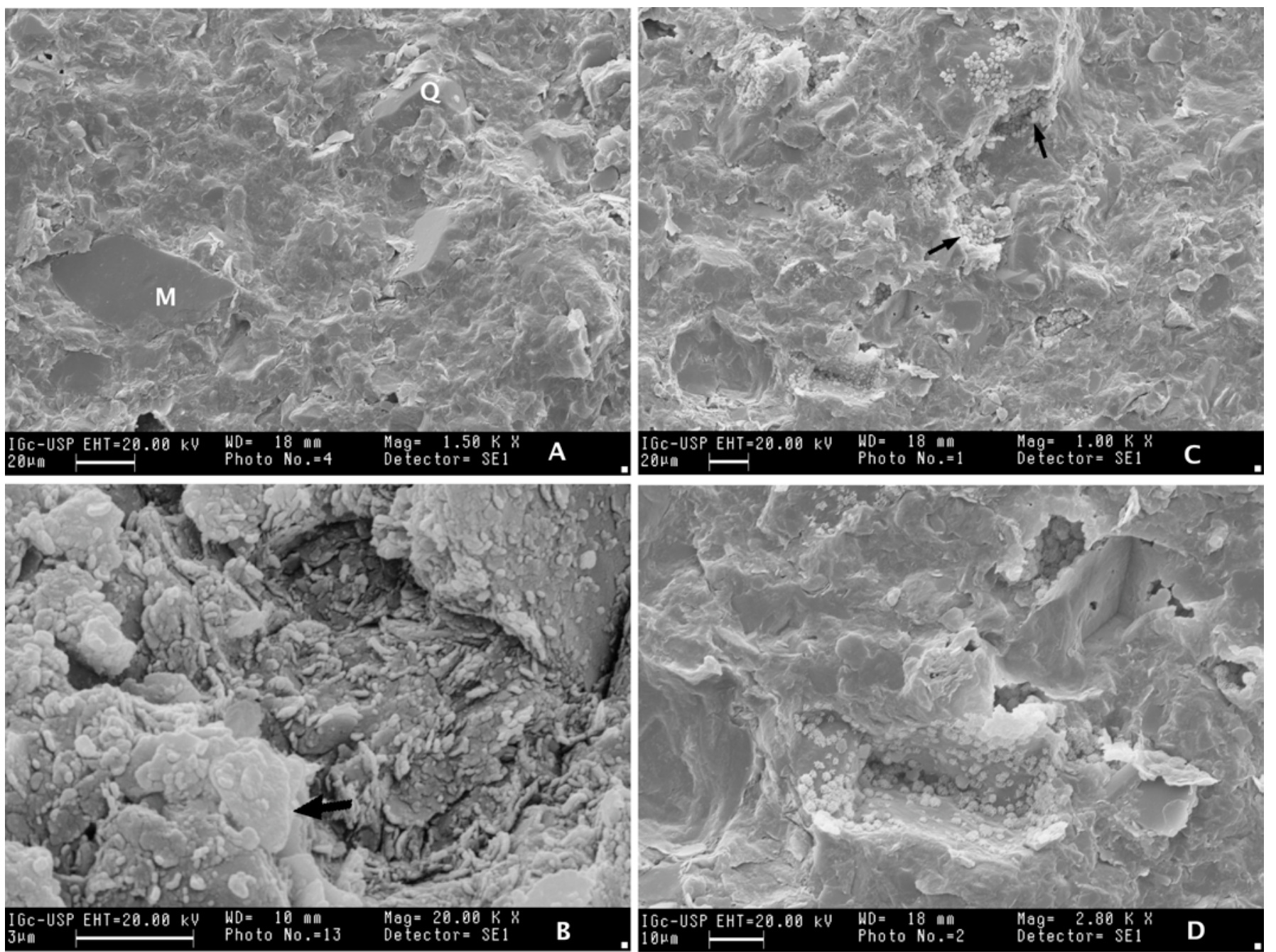

Figura 30- Imagens de MEV (sinal de elétrons secundários SE) do argilito coletado na Rua Bom Pastor. (A) Aspecto geral mostrando os grãos detríticos de quartzo (Q) e placa de mica (M), com granulação silte, imersos na matriz argilosa maciça. (B) Detalhe da matriz argilosa composta por placas arredondadas de argilomineral (seta preta). (C) Visão de lepisferas de sílica preenchendo a porosidade esparsa (seta preta). (D) Detalhe das lepisferas de sílica preenchendo paredes de cavidade ocupada anteriormente por grão detrítico (parte central da imagem). 

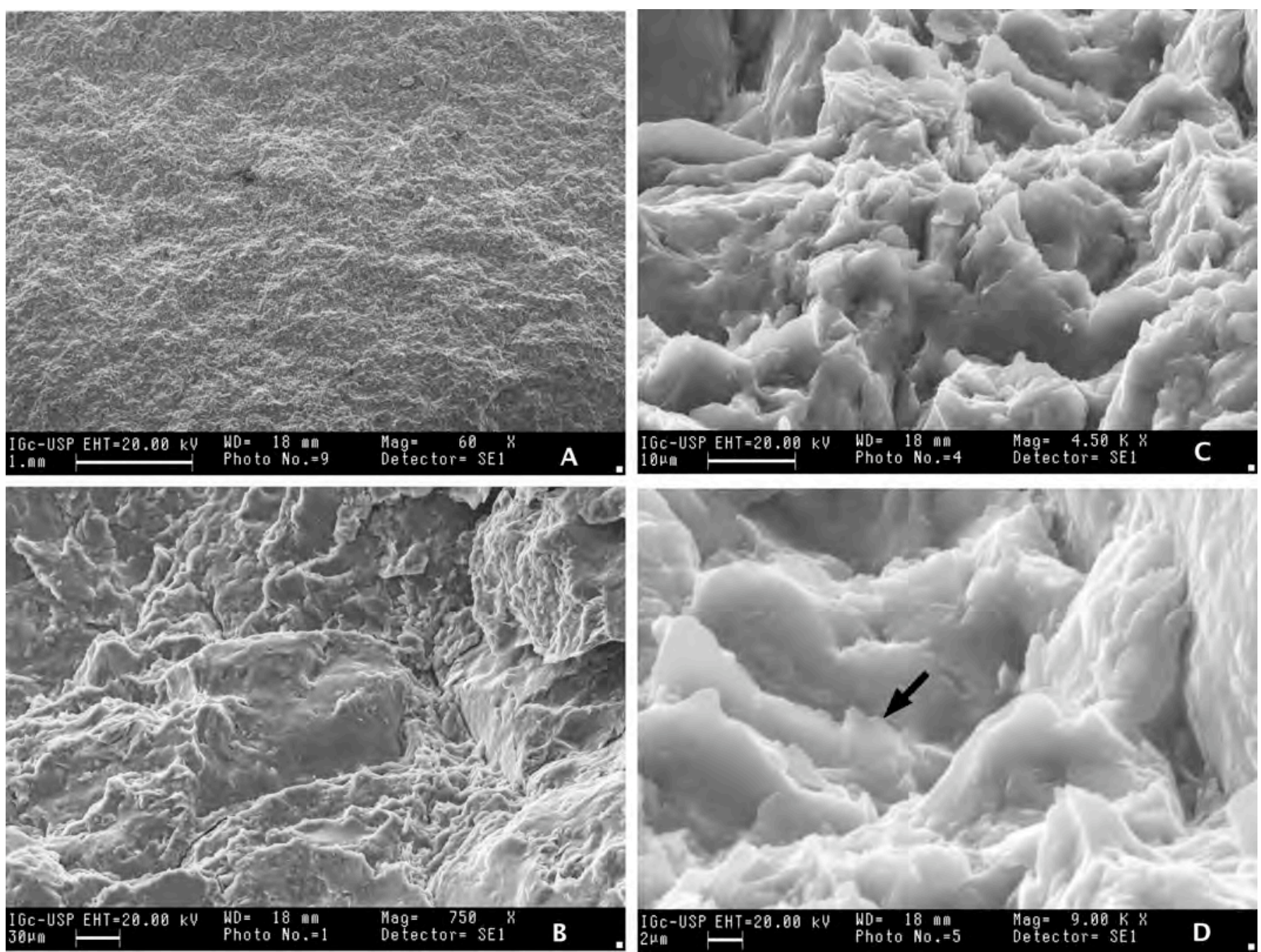

Figura 31- Imagens de MEV (SE) do argilito coletado na Av. Juntas Provisórias. (A) Visão geral do argilito mostrando sua estrutura maciça. (B) Detalhe de grão de quartzo detrítico imerso na matriz argilosa. (C) Detalhe do empacotamento de argilominerais na matriz do argilito. (D) Detalhe mostrando as bordas corroídas e irregulares (vide seta preta) das placas de argilominerais constituintes da matriz do argilito. 

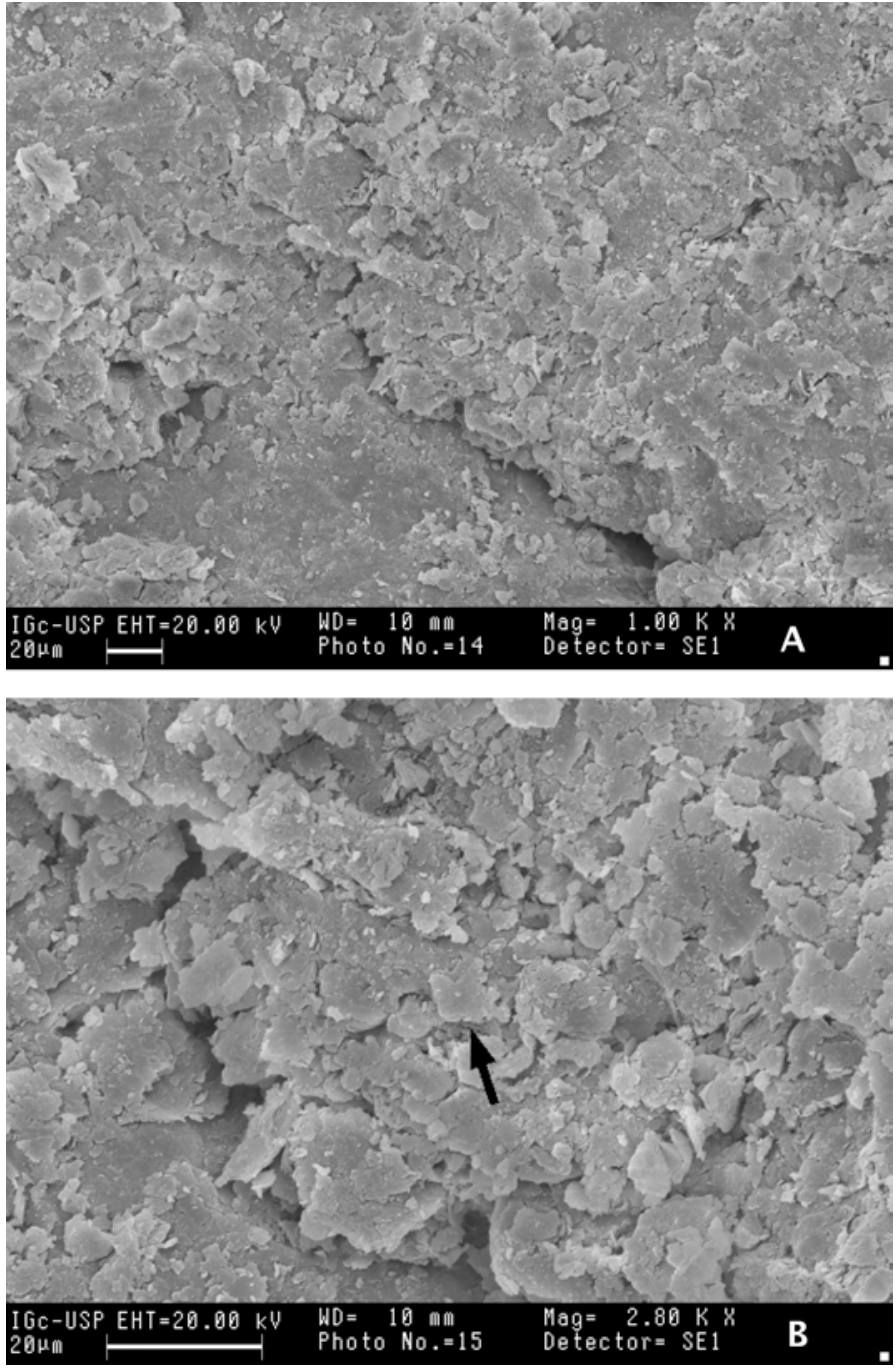

Figura 32 - Imagens de MEV (SE) do argilito coletado na Rua Cavour. (A) Visão geral do argilito. (B) Detalhe das placas arredondadas (vide seta preta) de argilominerais constituintes da matriz do argilito.

\section{Resultados dos ensaios de sorção e desorção}

\subsection{Testes de inchamento}

Os testes de inchamento realizados para rocha total dos argilitos da Formação Resende não revelaram qualquer variação de volume das amostras testadas com os hidrocarbonetos gasolina comum, benzeno P.A., tolueno P.A. e xileno P.A.

Após a execução dos testes de inchamento, as amostras foram submetidas à análise por difração de raios X para confirmação de que não houve aumento no espaço interplanar. Essa confirmação foi obtida a partir da medição da reflexão basal 001 do argilomineral esmectítico, que se manteve em cerca de $15 \AA ̊$, na região de $5.0^{\circ} 2 \theta$. Os difratogramas obtidos são apresentados na (Figura 33). 

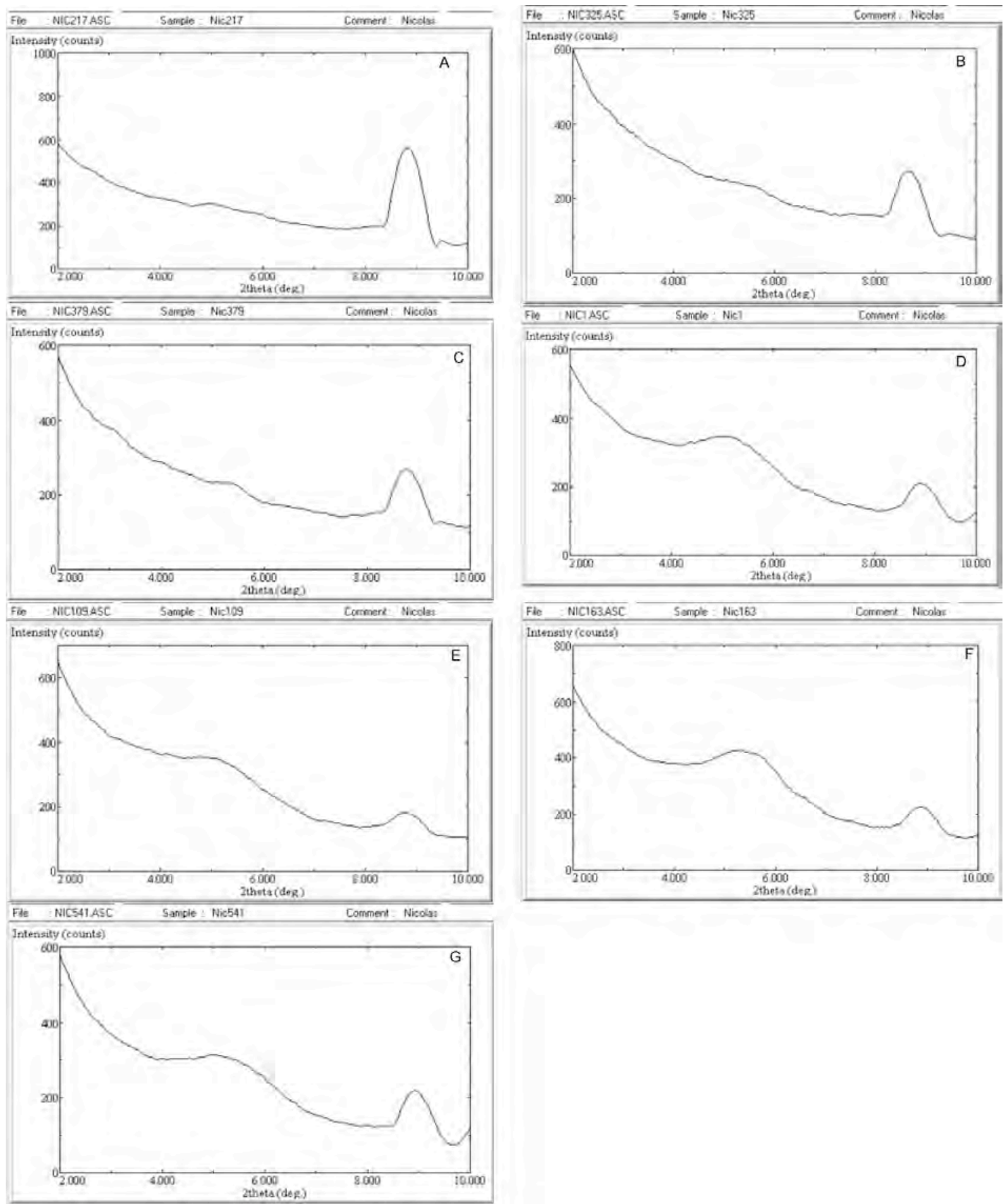

Figura 33 - Difratogramas de raios $X$ de rocha total dos argilitos da Formação Resende analisados pelo teste de inchamento. (A) Amostra BP, contaminada com gasolina, (B) Amostra BP, contaminada com tolueno, (C) Amostra $\mathrm{BP}$, contaminada com xileno, (D) Amostra JP, contaminada com gasolina, (E) Amostra JP, contaminada com tolueno, (F) Amostra JP, contaminada com xileno, (G) Amostra CA, contaminada com tolueno. 


\subsection{Teste de adsorção}

Os resultados das análises de benzeno, tolueno, etilbenzeno e xileno (BTEX), realizadas por cromatografia gasosa a partir dos testes de adsorção com argilitos da Formação Resende, foram compilados em tabelas apresentadas no Anexo. Para a representação e análise dos dados, gráficos binários tempo de contato $x$ concentração de contaminante foram elaborados para o conjunto de amostras testadas com gasolina comum, benzeno P.A., tolueno P.A. e xileno P.A. Devido à utilização de compostos orgânicos puros, os teores de o-xileno são em sua maioria não detectáveis, ou muito dispersos, de modo que não foram apresentados gráficos com esse composto.

\subsubsection{Argilito coletado na Rua Bom Pastor}

\section{Gasolina}

Os teores de BTEX medidos na rocha total e frações finas (silte e argila) do argilito da Formação Resende coletado em frente de obra nas vizinhanças da Rua Bom Pastor (amostra BP), após contaminação com gasolina no teste de adsorção, são apresentados nos gráficos da Figura 34. Nessa figura, apenas os teores de BTEX da fração argila testada com tempo de contato de 30 minutos não estão disponíveis.

Nos gráficos, nota-se que os teores de BTEX variam de forma similar ao longo dos tempos de contato. As concentrações de BTEX referentes aos tempos de 30 minutos e 2 horas são elevadas, decrescendo significativamente no tempo de 6 horas, sendo estas as menores encontradas. Nos tempos de $18 \mathrm{~h}, 24 \mathrm{~h}$ e 4 dias as concentrações aumentam progressivamente, seguindo-se nova queda em 16 dias. Há uma tendência de aumento para benzeno e xilenos e de estabilização para tolueno e etilbenzeno aos 32 dias. A observação dos gráficos mostra ainda que:

- as concentrações de BTEX na rocha total descrevem bem a variação encontrada, que se caracteriza por altos teores em $30 \mathrm{~min}$. e $2 \mathrm{~h}$, seguido de decréscimo em $6 \mathrm{~h}$ e $18 \mathrm{~h}$, posterior aumento em $24 \mathrm{~h}$ e 4 dias, redução a 16 dias e tendência de aumento em 32 dias;

- a fração silte diferencia-se da rocha total por apresentar baixa concentração de BTEX em 30 minutos. No restante dos tempos, a fração silte também exibe baixos teores a $6 \mathrm{~h}$ e 16 dias, aumento progressivo de $18 \mathrm{~h}$ a 4 dias e aumento a 32 dias;

- a fração argila apresenta altos teores de BTEX após $2 \mathrm{~h}$ de contato e baixos teores em $6 \mathrm{~h}$, seguido de aumento progressivo até 4 dias, quando atinge o máximo em TEX. Os teores referentes a 16 e 32 dias mantém-se em elevação para benzeno e tendência de queda para TEX.

Quando comparados os dados de rocha total e frações finas em gráficos com escala logarítmica (Figura 35), nota-se que as concentrações de BTEX têm comportamentos similares, diferenciando-se mais claramente apenas em tempos mais longos (16 e 32 dias). No tempo de 16 dias, a argila apresenta teores maiores do que a rocha total e fração silte em pelo menos uma ordem de grandeza. Após 32 dias de contato, ambas as frações finas apresentam altos teores.

De modo geral, os teores de mp-xilenos tendem a ser mais elevados que os demais compostos, sendo seguido, em ordem decrescente, por tolueno, o-xileno, benzeno e etilbenzeno, tanto na rocha total quanto nas frações finas. Na rocha total, fração silte e fração argila, os teores variam, respectivamente:

- mp-xilenos: de 5.500 a $27.000 \mathrm{mg} / \mathrm{kg}$, de 3.500 a $23.700 \mathrm{mg} / \mathrm{kg}$, de 8.000 a 27.500 $\mathrm{mg} / \mathrm{kg}$ 
- tolueno: de 2.600 a $13.000 \mathrm{mg} / \mathrm{kg}$, de 1.600 a $9.900 \mathrm{mg} / \mathrm{kg}$, de 3.300 a 11.100 $\mathrm{mg} / \mathrm{kg}$

- o-xileno: de 1.700 a $9.200 \mathrm{mg} / \mathrm{kg}$, de 1.500 a $7.200 \mathrm{mg} / \mathrm{kg}$, de 2.200 a $8.300 \mathrm{mg} / \mathrm{kg}$

- benzeno: de 600 a $6.200 \mathrm{mg} / \mathrm{kg}$, de 190 a $11.000 \mathrm{mg} / \mathrm{kg}$, de 720 a $6.900 \mathrm{mg} / \mathrm{kg}$

- etilbenzeno de 800 a $5.200 \mathrm{mg} / \mathrm{kg}$, de 700 a $3.800 \mathrm{mg} / \mathrm{kg}$, de 1.000 a $4.300 \mathrm{mg} / \mathrm{kg}$

\section{Benzeno, Tolueno, mp-Xilenos}

As concentrações de benzeno, tolueno e mp-xilenos medidas a partir do teste de adsorção com rocha total e frações finas da amostra BP contaminadas com esses compostos puros são apresentadas na Figura 36, em função dos tempos de contato empregados.

Apesar de alguns dados estarem ausentes, nota-se o comportamento oscilatório das concentrações de BTX, com os maiores valores ocorrendo em tempos curtos (30 min., $2 \mathrm{~h}$ ), intermediários (18h, 24h e 4 dias) e longo (32 dias), enquanto os menores valores apresentam-se às $6 \mathrm{~h}$ e 16 dias, tanto na rocha total como nas frações finas. Esse comportamento, visível no gráfico de mp-xilenos (Figura 36C), de modo geral, concorda com o encontrado para rocha total e frações finas da amostra BP contaminada com gasolina e analisada para xilenos (Figura 34D, Figura 34E).

Os teores de BTX são, geralmente, maiores do que os obtidos no teste de adsorção com gasolina, pois foram utilizados compostos puros. Há uma ampla variação na ordem de grandeza dos teores dos contaminantes, que apresentam-se na rocha total, fração silte e fração argila, respectivamente:

- benzeno: de 850 a $814.100 \mathrm{mg} / \mathrm{kg}$, de 41.500 a $568.600 \mathrm{mg} / \mathrm{kg}$, de 1.350 a 591.000 $\mathrm{mg} / \mathrm{kg}$

- tolueno: de 440 a $672.700 \mathrm{mg} / \mathrm{kg}$, de 5,66 a $486.500 \mathrm{mg} / \mathrm{kg}$, de 19.900 a 427.000 $\mathrm{mg} / \mathrm{kg}$

- xileno: de 30.200 a $1.200 .000 \mathrm{mg} / \mathrm{kg}$, de 14.330 a $845.400 \mathrm{mg} / \mathrm{kg}$, de 17.550 a $912.300 \mathrm{mg} / \mathrm{kg}$

Apesar da ampla variação e da ausência de alguns dados, nota-se que os teores apresentam certa coerência nas ordens de grandeza dos compostos nas frações analisadas. 

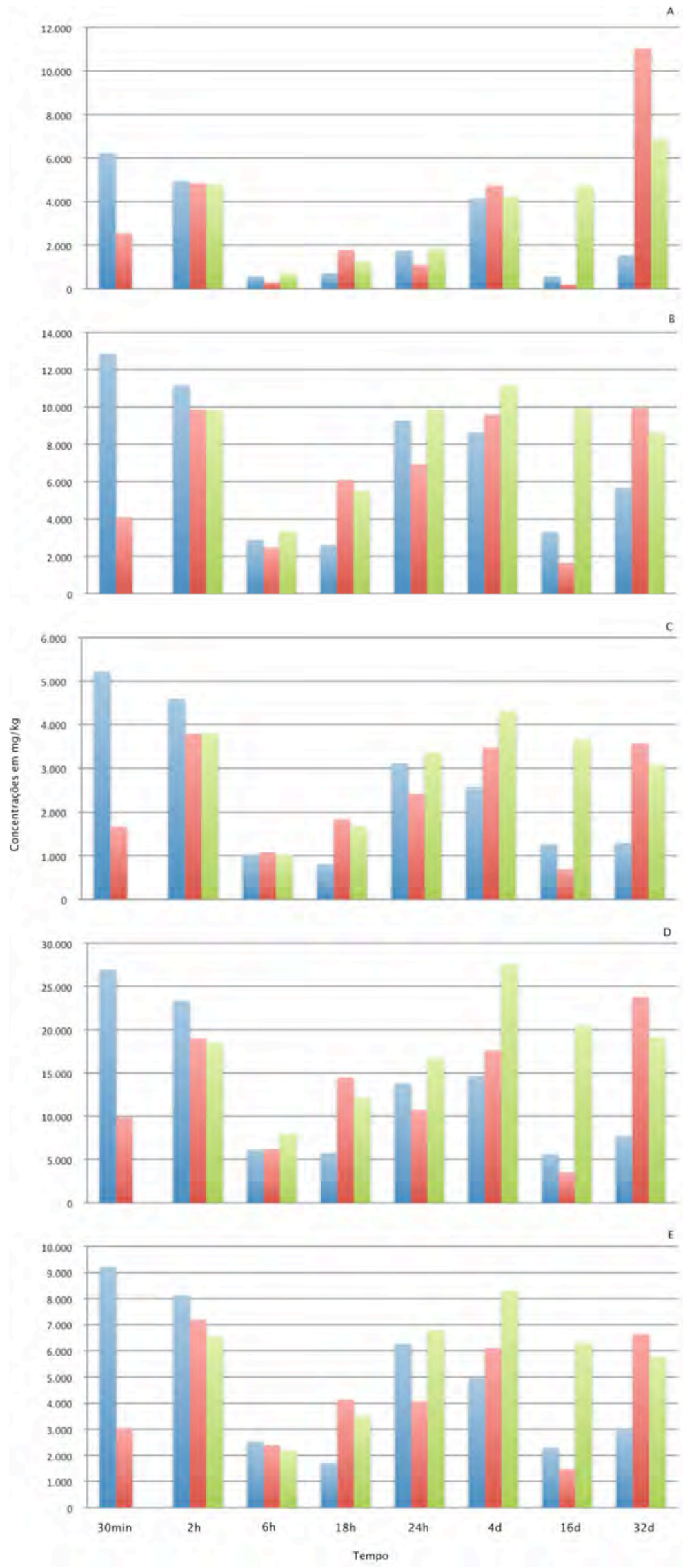

Figura 34 - Gráfico da variação da concentração de benzeno (A), tolueno (B), etilbenzeno (C), mp-xilenos (D) e o-xileno (E) em função do tempo de contato entre GASOLINA e a amostra BP (Legenda: azul - rocha total, vermelho - fração silte, verde - fração argila). 


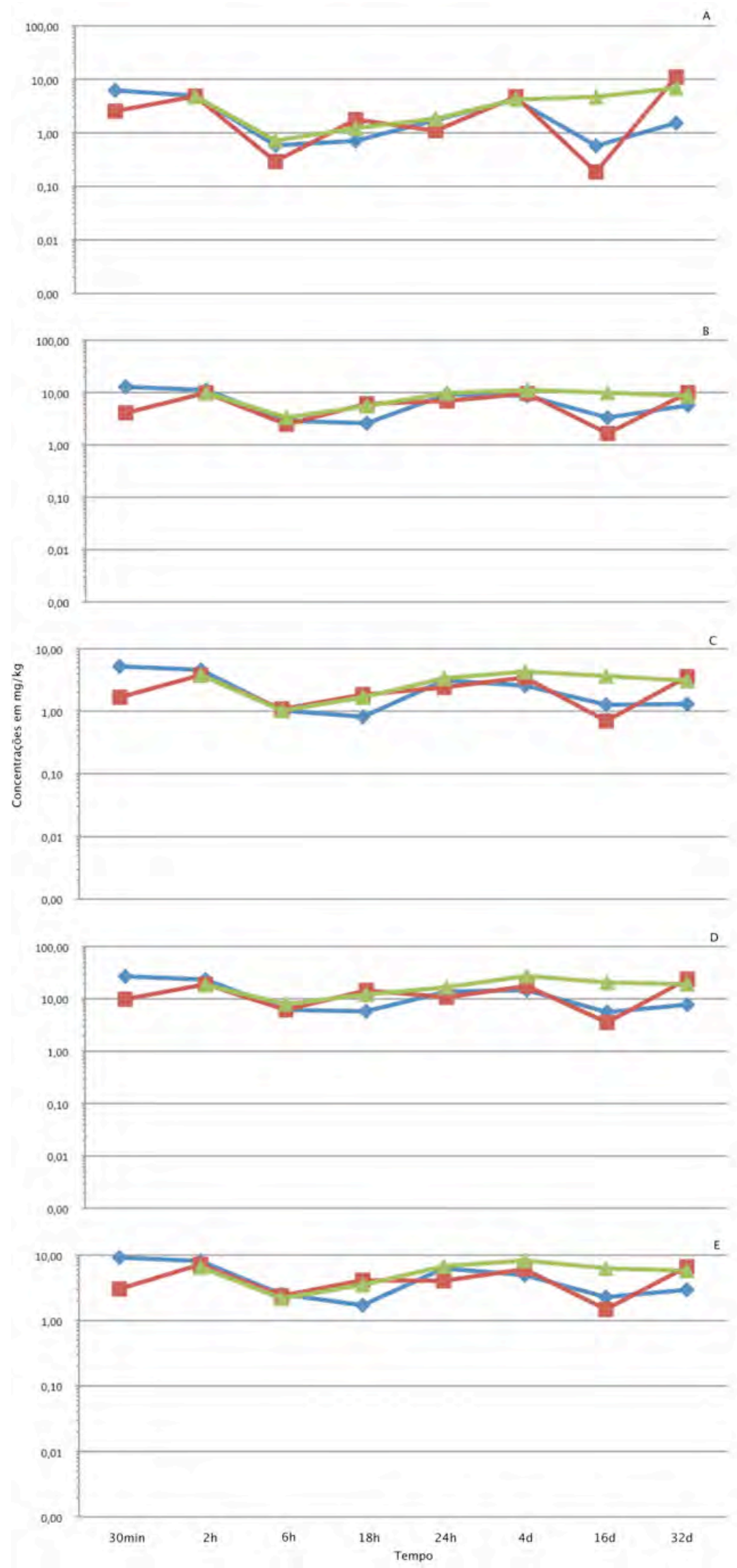

Figura 35 - Gráfico logarítmico da variação da concentração de benzeno (A), tolueno (B), etilbenzeno (C), mpxilenos (D) e o-xileno (E) em função do tempo de contato entre GASOLINA e a amostra BP (Legenda: azul - rocha total, vermelho - fração silte, verde - fração argila). 

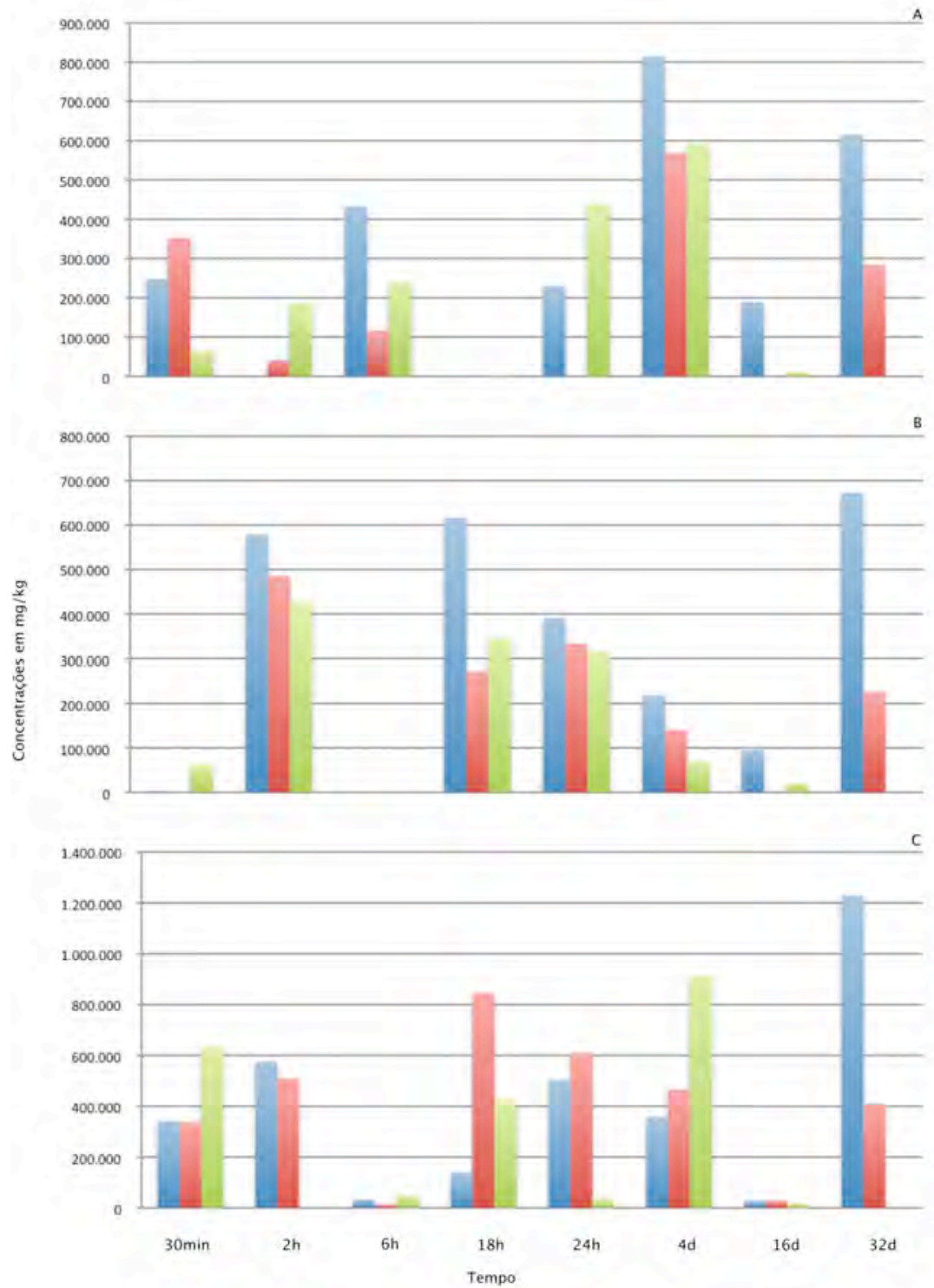

Figura 36 - Gráfico da variação da concentração de benzeno (A), tolueno (B) e mp-xilenos (C) em função do tempo de contato entre o CONTAMINANTE PURO e a amostra BP (Legenda: azul - rocha total, vermelho - fração silte, verde - fração argila).

\subsubsection{Argilito coletado na Avenida Juntas Provisórias}

\section{Gasolina}

As concentrações de BTEX fornecidas pela rocha total e frações finas (silte e argila) do argilito da Formação Resende coletado em frente de obra na Avenida Juntas Provisórias (amostra JP), após contaminação com gasolina no teste de adsorção, são apresentadas na Figura 37. Dados referentes aos tempos de 30 minutos e 24 horas estão ausentes para rocha total. Os dados disponíveis para silte e argila mostram que:

- os teores de mp-xilenos tendem a ser mais elevados que os demais, seguidos, em ordem decrescente, por tolueno, o-xileno, etilbenzeno e benzeno na rocha total e fração silte. Na fração argila, a mesma ordem é seguida, invertendo-se apenas benzeno e etilbenzeno. Na rocha total, os teores de mp-xilenos variam de 5.700 a $23.200 \mathrm{mg} / \mathrm{kg}$, tolueno de 2.400 a $11.400 \mathrm{mg} / \mathrm{kg}$, o-xileno de 1.700 a $6.800 \mathrm{mg} / \mathrm{kg}$, etilbenzeno de 800 a $4.300 \mathrm{mg} / \mathrm{kg}$ e benzeno de 600 a 4.800 . Na fração silte, os teores de mp-xilenos variam de 2.200 a $21.800 \mathrm{mg} / \mathrm{kg}$, tolueno de 900 a 11.300 
$\mathrm{mg} / \mathrm{kg}$, o-xileno de 600 a $7.800 \mathrm{mg} / \mathrm{kg}$, etilbenzeno de 300 a $4.400 \mathrm{mg} / \mathrm{kg}$ e benzeno de 130 a 5.500 . Na fração argila, os teores de mp-xilenos variam de 5.550 a $22.000 \mathrm{mg} / \mathrm{kg}$, tolueno de 2.800 a $11.000 \mathrm{mg} / \mathrm{kg}$, o-xileno de 1.900 a 8.500 $\mathrm{mg} / \mathrm{kg}$, benzeno de 600 a $9.000 \mathrm{mg} / \mathrm{kg}$ e etilbenzeno de 900 a $4.200 \mathrm{mg} / \mathrm{kg}$. Esses valores possuem ordem de grandeza semelhante aos identificados na rocha total e frações finas da amostra BP;

- na fração silte, as concentrações de BTEX referentes ao tempo de 30 minutos são inferiores àquelas de 2 horas;

- na fração argila, as concentrações obtidas no tempo de 30 minutos, quando comparadas àquelas de 2 horas, são inferiores para benzeno e superiores para TEX;

- em ambas as frações (silte e argila), as concentrações de BTEX de 6h e 18h são baixas;

- nas duas frações, benzeno apresenta altos teores em 4 dias e TEX em 24h e 4 dias;

- em ambas as frações finas há uma redução progressiva das concentrações de BTEX em 16 dias;

- as concentrações aos 32 dias são, geralmente, inferiores àquelas de 16 dias na fração silte e superiores na fração argila.

Quando comparados os dados da rocha total e frações finas em gráficos com escala logarítmica (Figura 38), nota-se que as concentrações de BTEX têm comportamentos muito similares entre os tempos de 30 minutos e 4 dias, passando a diferenciar-se em $16 \mathrm{e}$ 32 dias, quando a argila e a rocha total apresentam maiores teores do que a fração silte.

De modo geral, pode-se avaliar que a distribuição dos teores dos contaminantes na amostra JP é semelhante àquela na amostra BP (Figura 34), principalmente nas frações finas onde não há dados faltantes. A fração silte mantém baixas concentrações de BTEX após $6 \mathrm{~h}$ e 16 dias de contato com os contaminantes em ambas as amostras (BP e JP). Os dados da fração argila diferenciam-se apenas pelo fato das maiores concentrações de TEX ocorrerem a 24 horas na amostra JP e a 4 dias na amostra BP.

\section{Benzeno, Tolueno, mp-Xilenos}

Os gráficos da Figura 39 apresentam as concentrações de benzeno, tolueno e mpxilenos obtidas a partir do teste de adsorção da rocha total e frações finas da amostra JP com esses contaminantes puros.

Assim como observado na amostra BP, os teores de BTX são maiores do que os obtidos no teste com gasolina e apresentam ampla variação. Na rocha total, fração silte e fração argila, BTX varia, respectivamente:

- benzeno: de 250 a $491.000 \mathrm{mg} / \mathrm{kg}$, de 78.400 a $622.500 \mathrm{mg} / \mathrm{kg}$ e de 9.500 a $624.000 \mathrm{mg} / \mathrm{kg}$

- tolueno: de 2.300 a $398.000 \mathrm{mg} / \mathrm{kg}$, de 19.200 a $730.500 \mathrm{mg} / \mathrm{kg}$ e de 44.000 a $570.100 \mathrm{mg} / \mathrm{kg}$

- xileno: de 28.800 a $706.300 \mathrm{mg} / \mathrm{kg}$, de 40.000 a $353.400 \mathrm{mg} / \mathrm{kg}$ e de 36.600 a $1.170 .000 \mathrm{mg} / \mathrm{kg}$ 

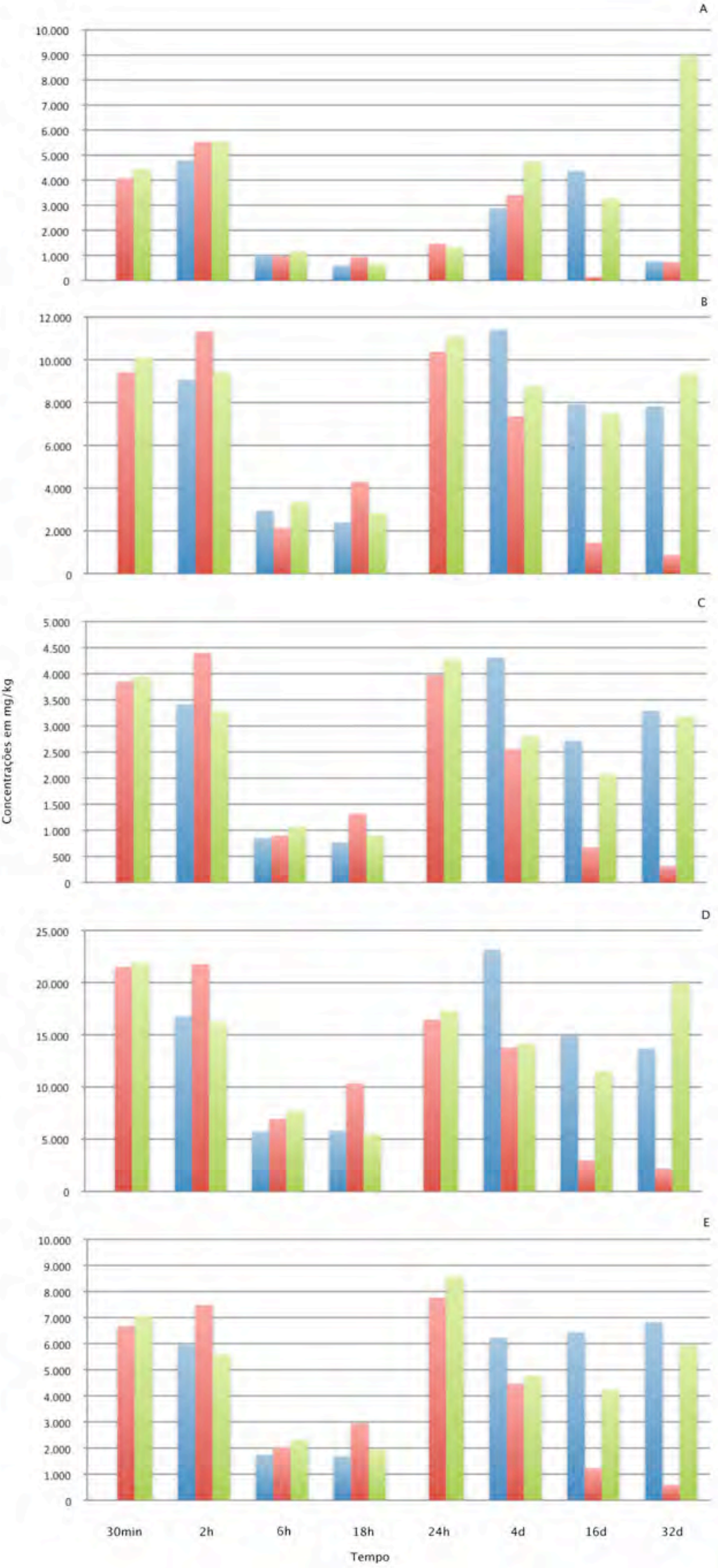

Figura 37 - Gráfico da variação da concentração de benzeno (A), tolueno (B), etilbenzeno (C), mp-xilenos (D) e o-xileno (D) em função do tempo de contato entre GASOLINA e a amostra JP (Legenda: azul - rocha total, vermelho - fração silte, verde - fração argila). 


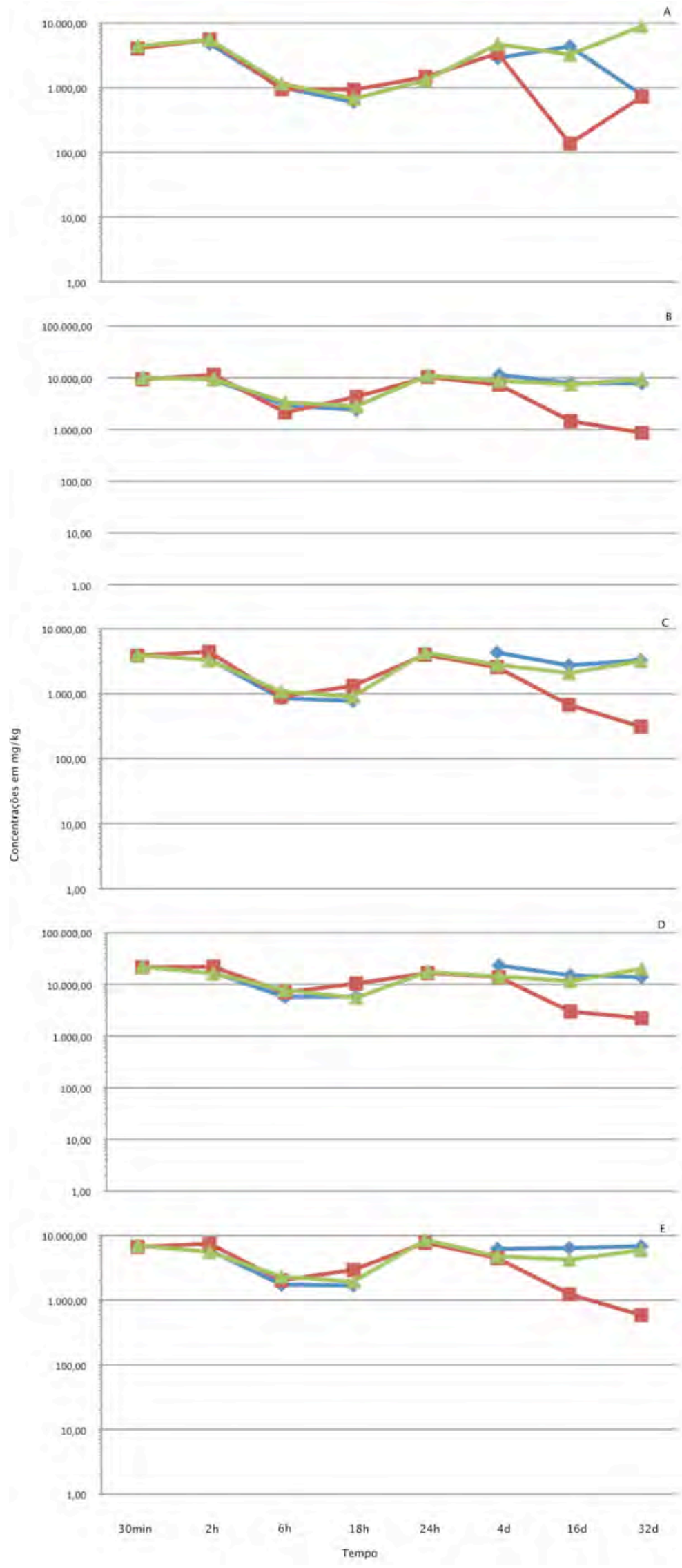

Figura 38 - Gráfico logarítmico da variação da concentração de benzeno (A), tolueno (B), etilbenzeno (C), mpxilenos (D) e o-xileno (E) em função do tempo de contato entre GASOLINA e a amostra JP (Legenda: azul - rocha total, vermelho - fração silte, verde - fração argila). 
Apesar da ampla variação e da ausência de alguns dados, nota-se que os teores apresentam coerência nas ordens de grandeza dos compostos nas frações analisadas e são concordantes com aqueles obtidos para a rocha total e frações finas da amostra BP.

Utilizando-se como referência o gráfico da Figura 39B, observa-se o comportamento oscilatório da distribuição dos teores de tolueno na rocha total e frações finas, com menores valores em 18h e 16 dias. A concentração do contaminante (tolueno) é alta em curtos tempos de contato com a amostra (30 min.), decrescendo até atingir o mínimo em 18h, seguido de aumento progressivo até 4 dias, diminuição a 16 dias e aumento em 32 dias.
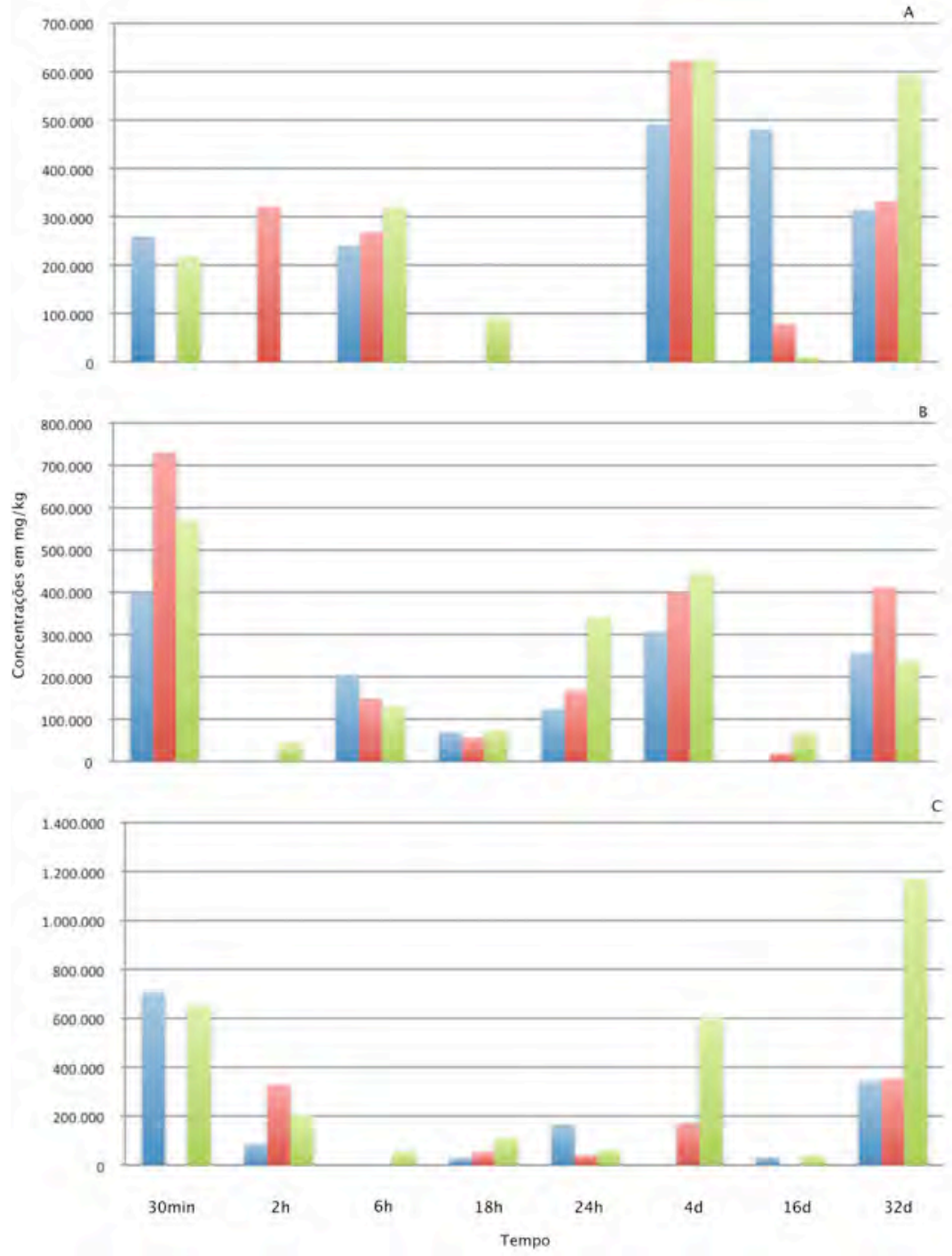

Figura 39 - Gráfico da variação da concentração de benzeno (A), tolueno (B) e mp-xilenos (C) em função do tempo de contato entre o CONTAMINANTE PURO e a amostra JP (Legenda: azul - rocha total, vermelho - fração silte, verde - fração argila).

\subsubsection{Argilito coletado na Rua Cavour}

\section{Gasolina}

As concentrações de BTEX fornecidas pela rocha total e frações finas (silte e argila) do argilito da Formação Resende coletado em frente de obra na Rua Cavour (amostra CA), após o teste de adsorção com gasolina, são apresentadas na Figura 40. Nos gráficos, não 
estão disponíveis as concentrações de BTEX da fração argila correspondentes aos tempos de 4 e 16 dias.

Assim como nas amostras BP e JP, os teores de mp-xilenos também tendem a ser mais elevados que os demais, seguido, em ordem decrescente, por tolueno, o-xileno, benzeno e etilbenzeno na rocha total e fração argila. Na fração silte, a mesma ordem é seguida, invertendo-se apenas etilbenzeno e benzeno. Na rocha total, fração silte e fração argila os teores de BTEX variam, respectivamente:

- mp-xilenos: de 5.500 a $18.500 \mathrm{mg} / \mathrm{kg}$, de 4.500 a $16.800 \mathrm{mg} / \mathrm{kg}$, de 7.500 a 28.200 $\mathrm{mg} / \mathrm{kg}$

- tolueno: de 1.500 a $9.100 \mathrm{mg} / \mathrm{kg}$, de 1.500 a $8.000 \mathrm{mg} / \mathrm{kg}$, de 3.300 a 13.100 $\mathrm{mg} / \mathrm{kg}$

- o-xileno: de 1.600 a $6.500 \mathrm{mg} / \mathrm{kg}$, de 1.400 a $5.500 \mathrm{mg} / \mathrm{kg}$, de 2.200 a $9.000 \mathrm{mg} / \mathrm{kg}$

- benzeno de 250 a $4.600 \mathrm{mg} / \mathrm{kg}$, de 230 a $3.600 \mathrm{mg} / \mathrm{kg}$, de 800 a $7.600 \mathrm{mg} / \mathrm{kg}$

- etilbenzeno de 730 a $3.600 \mathrm{mg} / \mathrm{kg}$, de 620 a $3.200 \mathrm{mg} / \mathrm{kg}$, de 1.000 a $5.000 \mathrm{mg} / \mathrm{kg}$

Esses valores concordam em ordem de grandeza com aqueles identificados para a amostra BP, tanto na rocha total quanto nas frações finas.

As distribuições dos teores dos compostos nos tempos de contato com a rocha total e a fração silte são muito semelhantes entre si. Há teores de BTEX mais elevados para tempos de 30 minutos e 2 horas, seguido de queda dos valores entre 6 e 18 horas, voltando a aumentar em 24 horas e 4 dias, nova diminuição em 16 dias e aumento dos teores em 32 dias. Esse comportamento é também similar ao observado para a rocha total da amostra BP (Figura 34) e as frações silte e argila da amostra JP (Figura 37). A fração argila da amostra CA apresenta teores elevados de BTEX após 30 minutos de contato, que decrescem até $18 \mathrm{~h}$, e voltam a aumentar nos tempos de $24 \mathrm{~h}$ e 32 dias.

Em gráficos com escala logarítmica (Figura 41) nota-se a semelhança na escala de valores das concentrações dos contaminantes entre a rocha total e as frações finas, além das menores concentrações nos tempos de 6 horas, 18 horas e 16 dias.

\section{Benzeno, Tolueno, mp-Xilenos}

Os gráficos da Figura 42 apresentam as concentrações de benzeno, tolueno e mpxilenos obtidas a partir do teste de adsorção desses contaminantes puros na rocha total e frações finas da amostra CA.

Apesar da ausência de alguns dados, o que torna a distribuição muito dispersa, nota-se, no conjunto dos gráficos, que os teores são baixos em 16 dias e altos em tempos curtos (30min) e longos ( $24 \mathrm{~h}, 4$ dias e 32 dias).

Os teores de BTX apresentam também ampla variação. Os teores de benzeno variam de 350 a $560.000 \mathrm{mg} / \mathrm{kg}$ na rocha total, de 4,10 a $822.200 \mathrm{mg} / \mathrm{kg}$ na fração silte e de $76.600 \mathrm{a}$ $557.300 \mathrm{mg} / \mathrm{kg}$ na fração argila. Tolueno ocorre de 48.000 a $208.200 \mathrm{mg} / \mathrm{kg}$ na rocha total, de 55.000 a $299.000 \mathrm{mg} / \mathrm{kg}$ na fração silte e de 28.600 a $602.000 \mathrm{mg} / \mathrm{kg}$ na fração argila. Xileno varia de 28.500 a $600.000 \mathrm{mg} / \mathrm{kg}$ na rocha total, de 24.500 a $350.000 \mathrm{mg} / \mathrm{kg}$ na fração silte e de 19.600 a $654.500 \mathrm{mg} / \mathrm{kg}$ na fração argila. Apesar da ampla variação e da ausência de alguns dados, nota-se que os teores apresentam coerência nas ordens de grandeza dos compostos nas frações analisadas e são concordantes com aqueles obtidos para a rocha total e frações finas da amostra BP. 

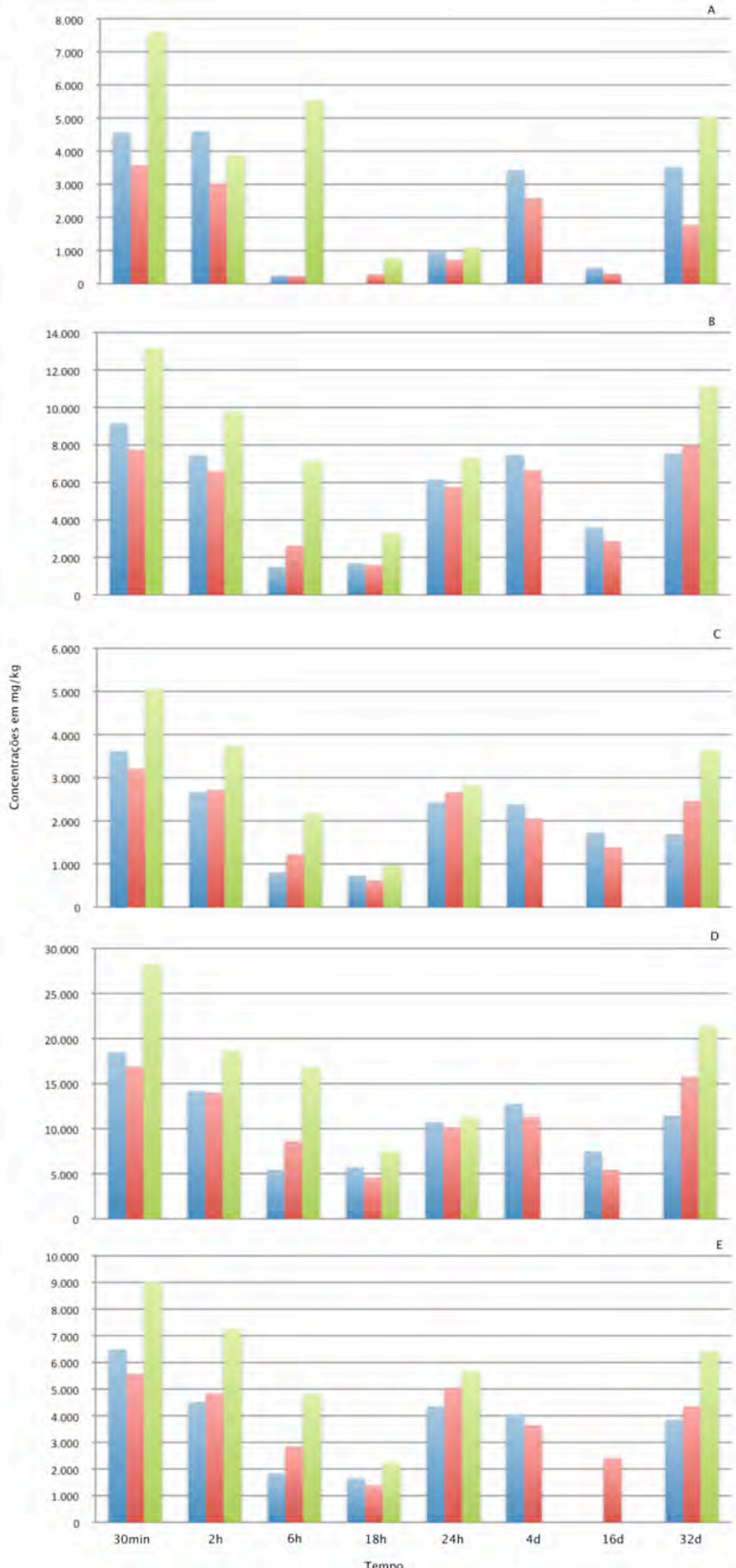

Figura 40 - Gráfico da variação da concentração de benzeno (A), tolueno (B), etilbenzeno (C), mp-xilenos (D) e oxileno (D) em função do tempo de contato entre GASOLINA e a amostra CA (Legenda: azul - rocha total, vermelho fração silte, verde - fração argila). 

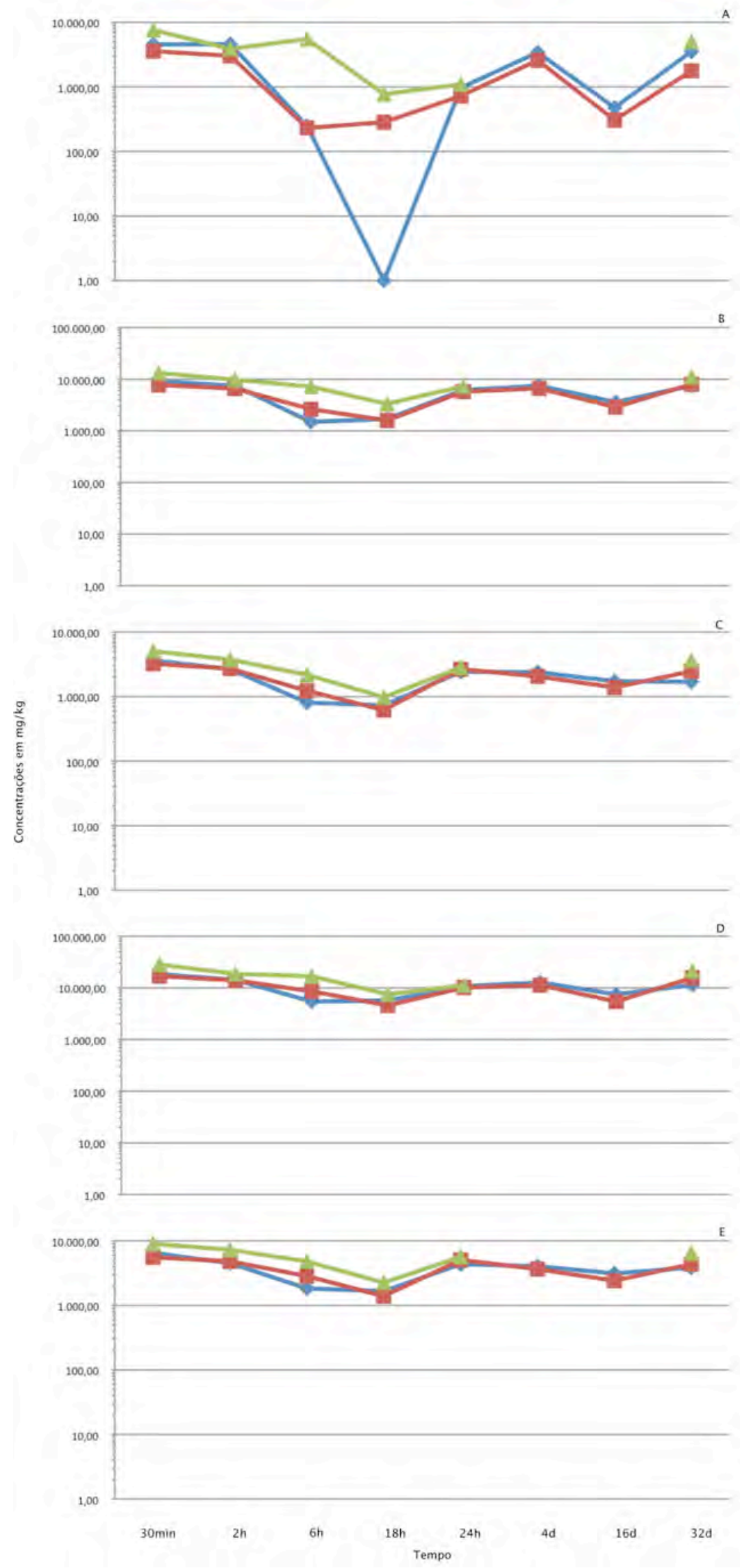

Figura 41 - Gráfico logarítmico da variação da concentração de benzeno (A), tolueno (B), etilbenzeno (C), mpxilenos (D) e o-xileno (E) em função do tempo de contato entre GASOLINA e a amostra CA (Legenda: azul - rocha total, vermelho - fração silte, verde - fração argila). 

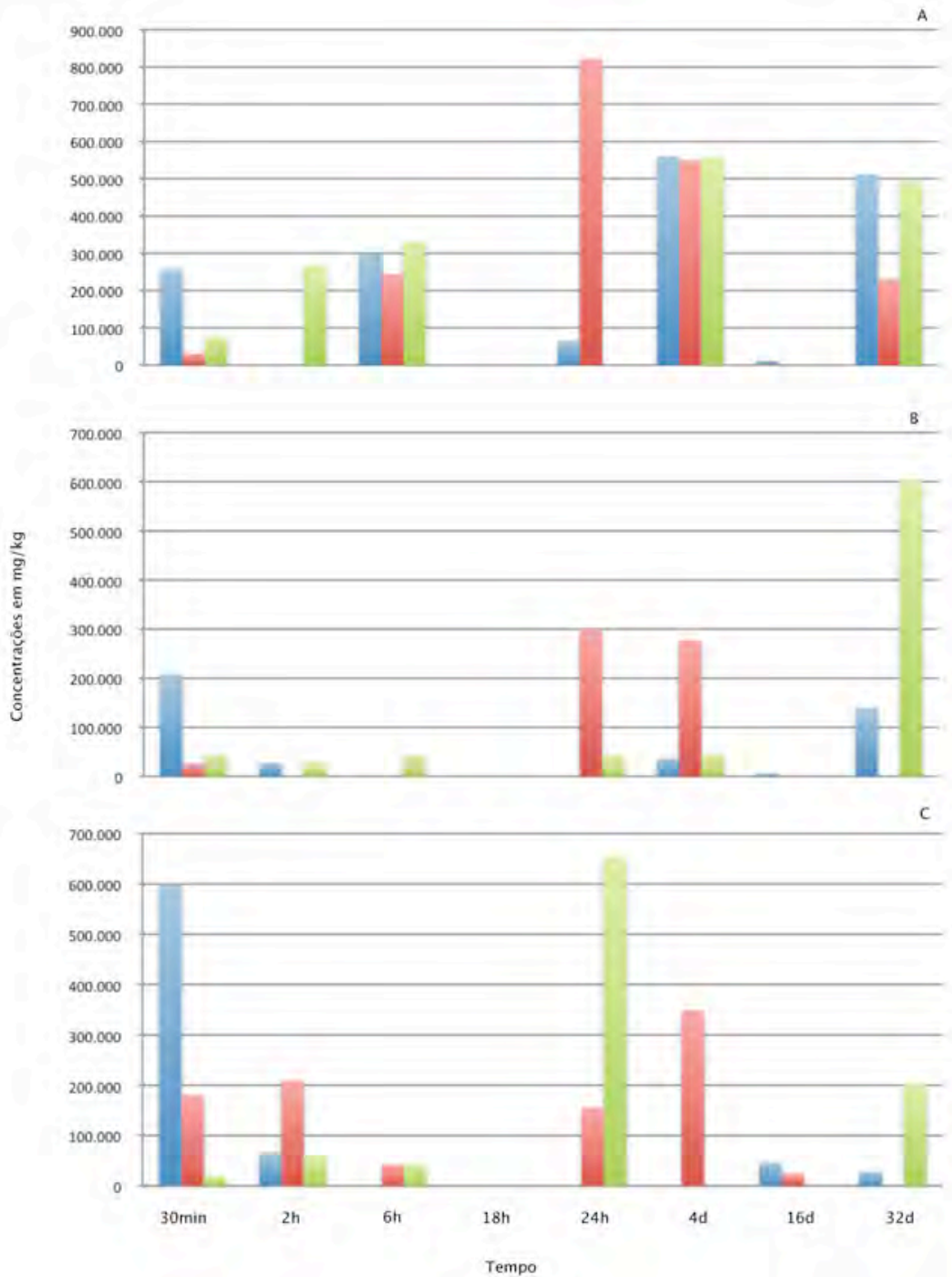

Figura 42 - Gráfico da variação da concentração de benzeno (A), tolueno (B) e mp-xilenos (C) em função do tempo de contato entre o CONTAMINANTE PURO e a amostra CA (Legenda: azul - rocha total, vermelho - fração silte, verde - fração argila).

\subsection{Teste de desorção}

Os resultados das análises de benzeno, tolueno, etilbenzeno e xileno (BTEX), realizadas por cromatografia gasosa a partir dos testes de desorção (item 4.3.4) com argilitos da Formação Resende, foram compilados em tabelas apresentadas no Anexo. Para a representação e análise dos dados, gráficos binários tempo de desorção x concentração de contaminante foram elaborados para o conjunto de amostras testadas com gasolina comum, benzeno P.A., tolueno P.A. e xileno P.A. Os teores de o-xileno não foram apresentados em gráficos pelo fato de não serem, em sua maioria, detectáveis ou estarem muito dispersos, devido à utilização de compostos orgânicos puros. 


\subsubsection{Argilito coletado na Rua Bom Pastor}

\section{Gasolina}

Os teores de BTEX medidos na rocha total e frações finas (silte e argila) do argilito da Formação Resende coletado em frente de obra nas vizinhanças da Rua Bom Pastor (amostra BP), após o teste de desorção com gasolina, são apresentados na Figura 43.

Nesses gráficos, nota-se que as mais altas concentrações de BTEX ainda retidas pela rocha total e frações finas ocorrem às $24 \mathrm{~h}$ de desorção do contaminante (gasolina comum). Concentrações de BTEX inferiores ocorrem em tempos menores ( $6 \mathrm{~h}$ e $18 \mathrm{~h}$ ) e maiores (4 e 16 dias). Aos 32 dias de desorção, as concentrações decrescem significativamente, inclusive para mp-xilenos (Figura 43D), ainda que a amostra permaneça contaminada.

\section{Benzeno, Tolueno, mp-Xilenos}

Os gráficos da Figura 44 apresentam as concentrações de benzeno, tolueno e mpxilenos obtidas a partir do teste de desorção desses contaminantes puros pela rocha total e frações finas da amostra BP. Essas concentrações são superiores àquelas encontradas após o teste de desorção com gasolina comum, tanto na rocha total quanto nas frações finas.

Os dados obtidos para xileno mostram o comportamento oscilatório do teor do contaminante na rocha total e frações finas, que retêm altas concentrações após $2 \mathrm{~h}, 18 \mathrm{~h}$ e 32 dias de desorção. Concentrações menores foram encontradas para $6 \mathrm{~h}, 4$ e 16 dias de desorção. 

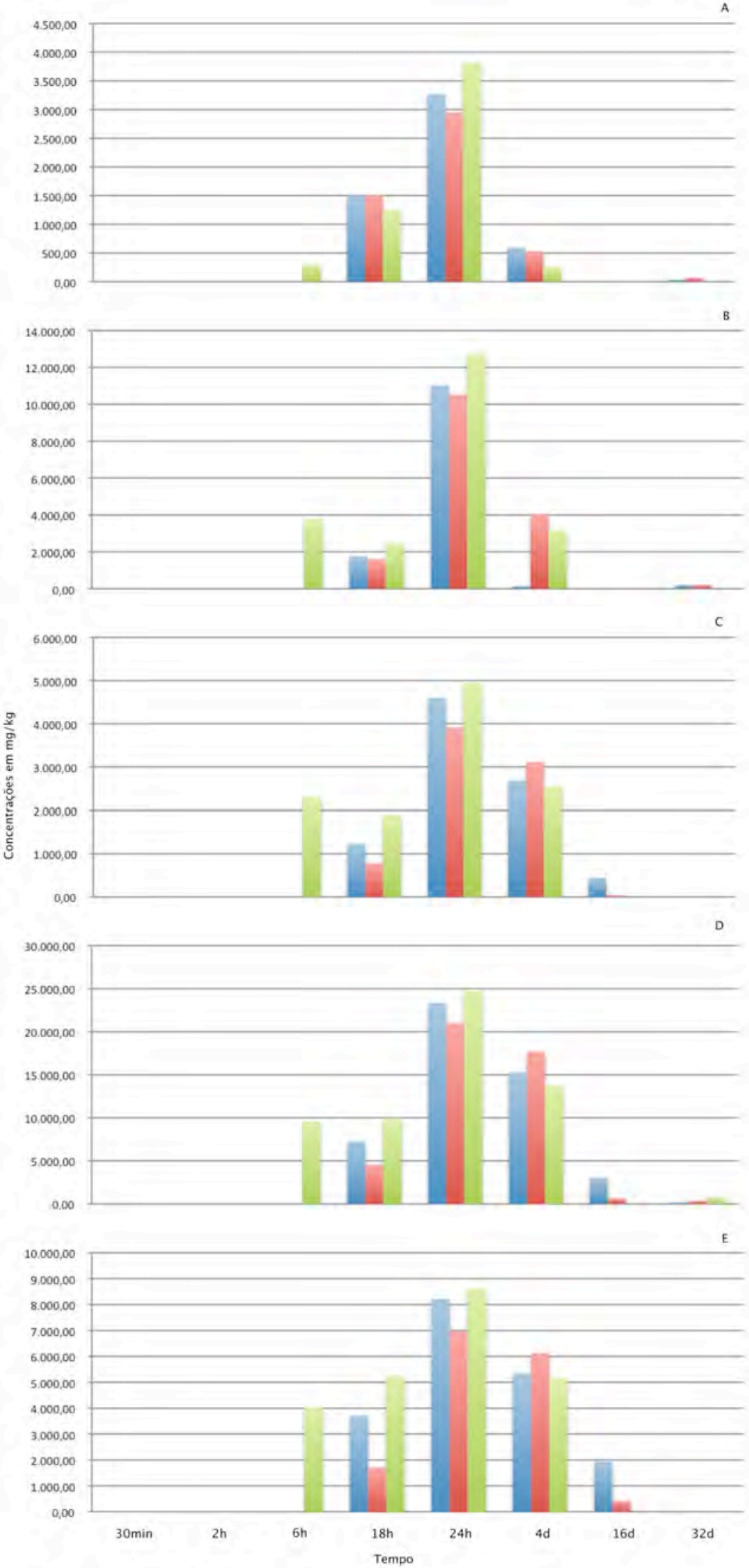

Figura 43- Gráfico da variação da concentração de benzeno (A), tolueno (B), etilbenzeno (C), mp-xilenos (D) e oxileno (D) em função do tempo de desorção de GASOLINA na amostra BP (Legenda: azul - rocha total, vermelho fração silte, verde - fração argila). 


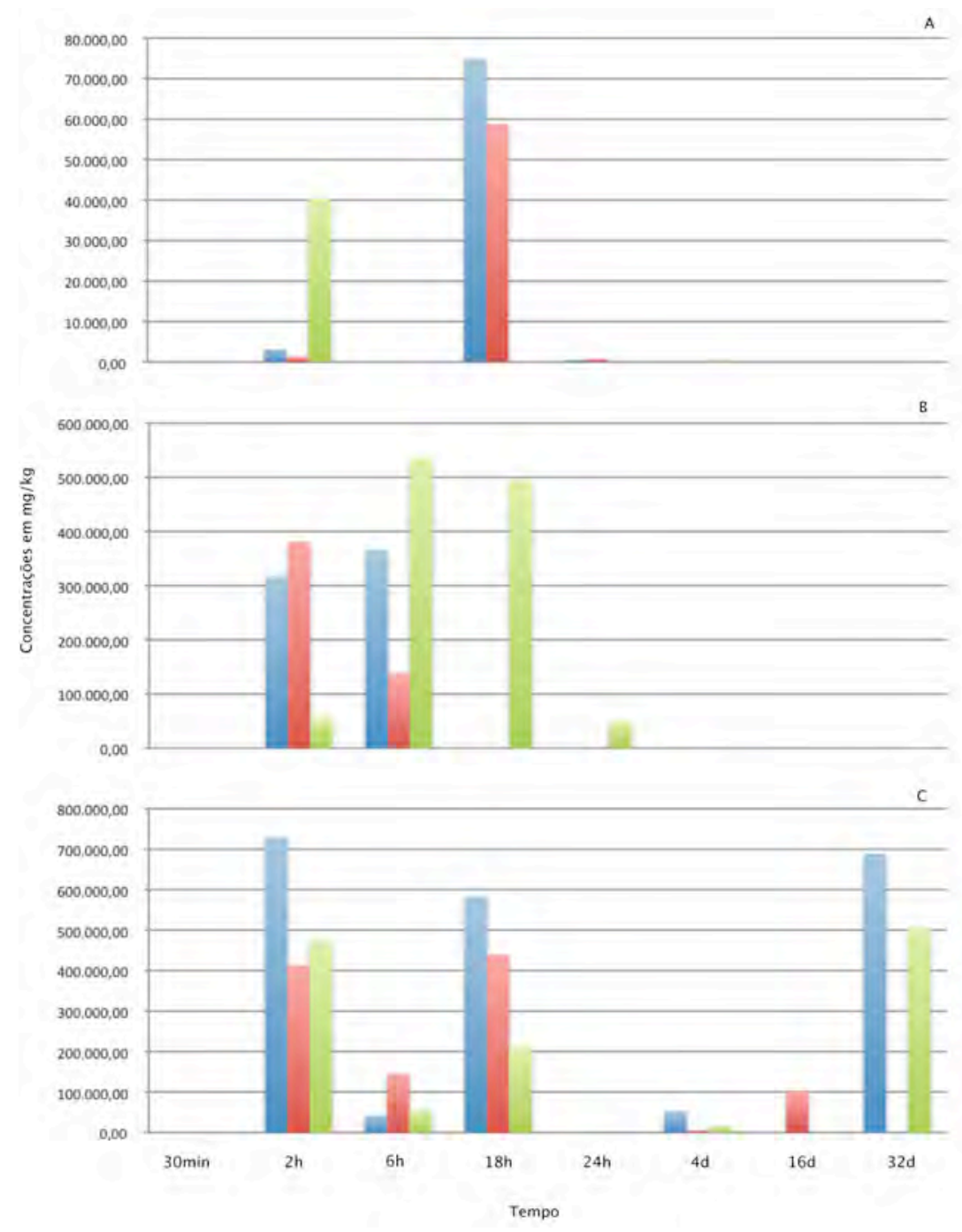

Figura 44 - Gráfico da variação da concentração de benzeno (A), tolueno (B) e mp-xilenos (C) em função do tempo de desorção do CONTAMINANTE PURO na amostra BP (Legenda: azul - rocha total, vermelho - fração silte, verde - fração argila).

\subsubsection{Argilito coletado na Avenida Juntas Provisórias}

\section{Gasolina}

Os teores de BTEX medidos na rocha total e frações finas (silte e argila) do argilito da Formação Resende coletado em frente de obra na Av. Juntas Provisórias (amostra JP), após o teste de desorção com gasolina, são apresentados na Figura 45.

As mais altas concentrações de BTEX ainda retidas pela rocha total e frações finas ocorrem após 24h e 4 dias de desorção. Concentrações de BTEX inferiores estão presentes em tempos menores ( $6 \mathrm{~h}$ e $18 \mathrm{~h})$ maiores (16 e 32 dias). De modo geral, esse comportamento é muito similar ao descrito para a amostra BP. 

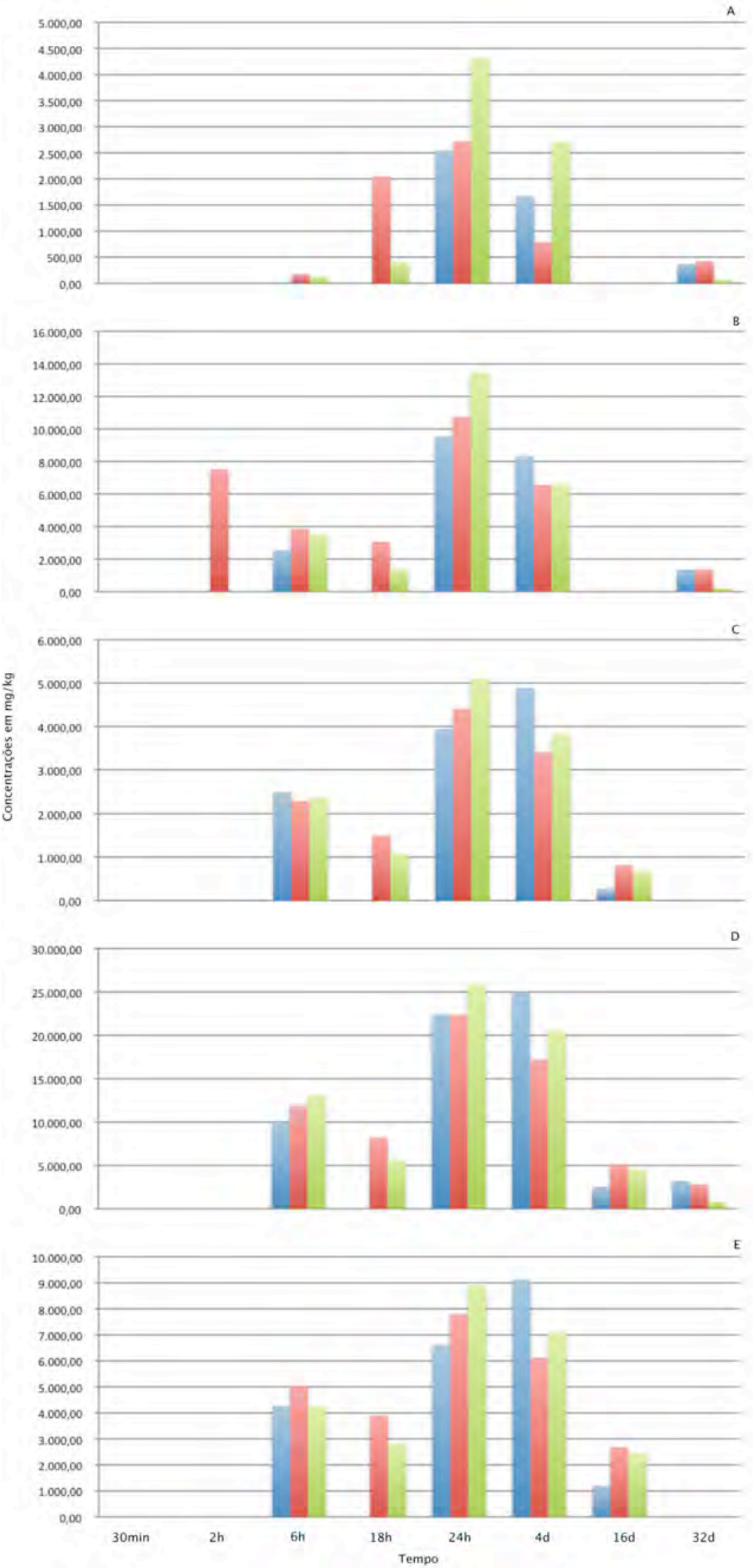

Figura 45 - Gráfico da variação da concentração de benzeno (A), tolueno (B), etilbenzeno (C), mp-xilenos (D) e oxileno (D) em função do tempo de desorção de gasolina na amostra JP (Legenda: azul - rocha total, vermelho fração silte, verde - fração argila). 


\section{Benzeno, Tolueno, mp-Xilenos}

A Figura 46 apresenta as concentrações de benzeno, tolueno e mp-xilenos obtidas a partir do teste de desorção desses contaminantes puros pela rocha total e frações finas da amostra JP. Ressalta-se as altas concentrações de BTX ainda retidas após 4 dias de desorção, tanto pela rocha total quanto pelas frações finas. Teores inferiores ocorrem em tempos de desorção de 2h, 6h, 4, 16 e 32 dias. Essa distribuição dos teores é coerente com o comportamento descrito anteriormente para a amostra BP.

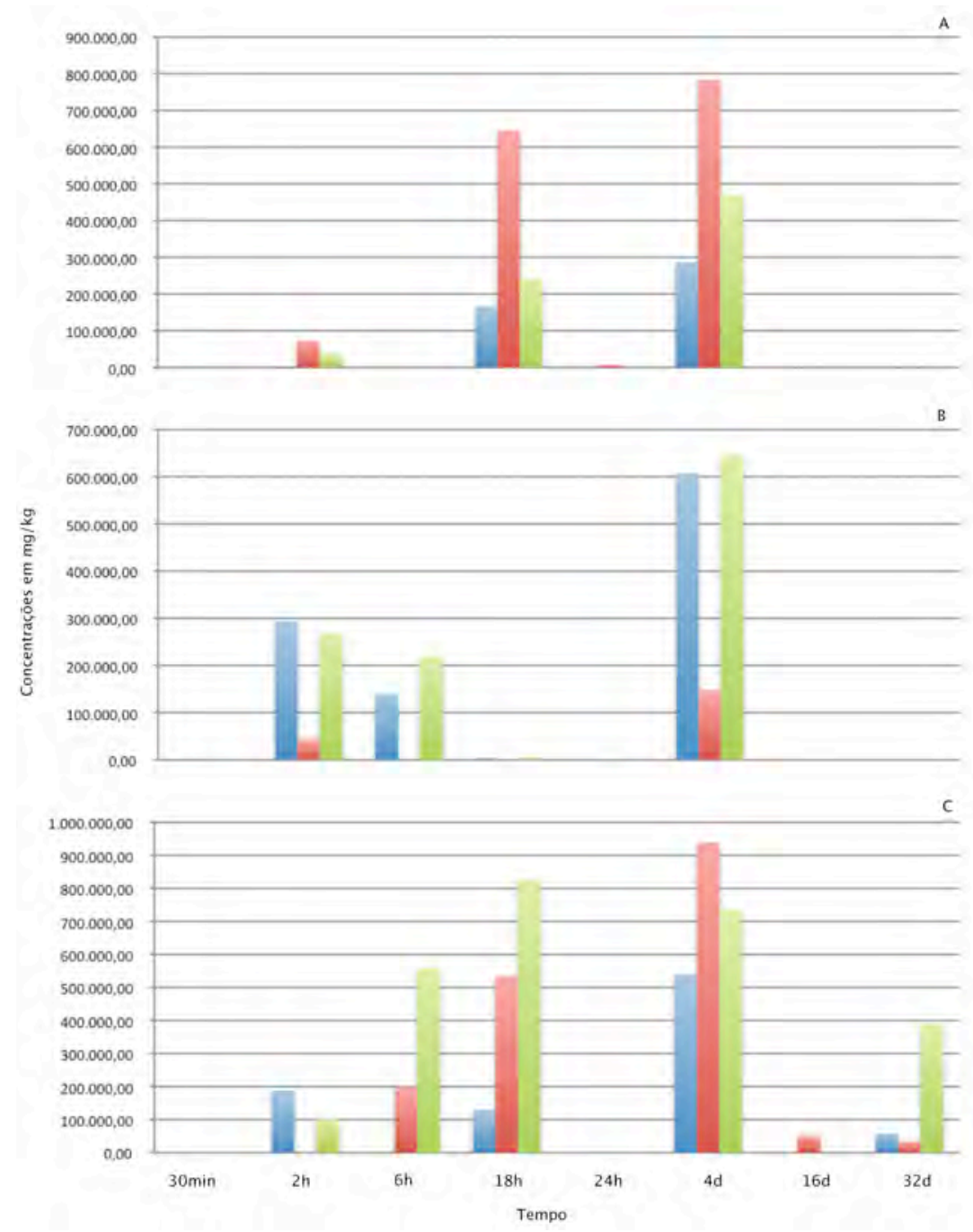

Figura 46 - Gráfico da variação da concentração de benzeno (A), tolueno (B) e mp-xilenos (C) em função do tempo de desorção do CONTAMINANTE PURO na amostra JP (Legenda: azul - rocha total, vermelho - fração silte, verde - fração argila).

\subsubsection{Argilito coletado na Rua Cavour}

\section{Gasolina}

A Figura 47 apresenta os dados de BTEX obtidos no teste de desorção de gasolina pelo argilito da Formação Resende coletado na Rua Cavour (amostra CA), testado na forma de rocha total e frações finas.

Os dados tendem a acompanhar o comportamento descrito para as amostras BP e JP. Destacam-se as altas concentrações de BTEX após 24 horas de desorção. Concentrações inferiores ocorrem em tempos mais curtos (6h e 18h) e mais longos (16 e 32 dias), sendo estas as menores encontradas. 

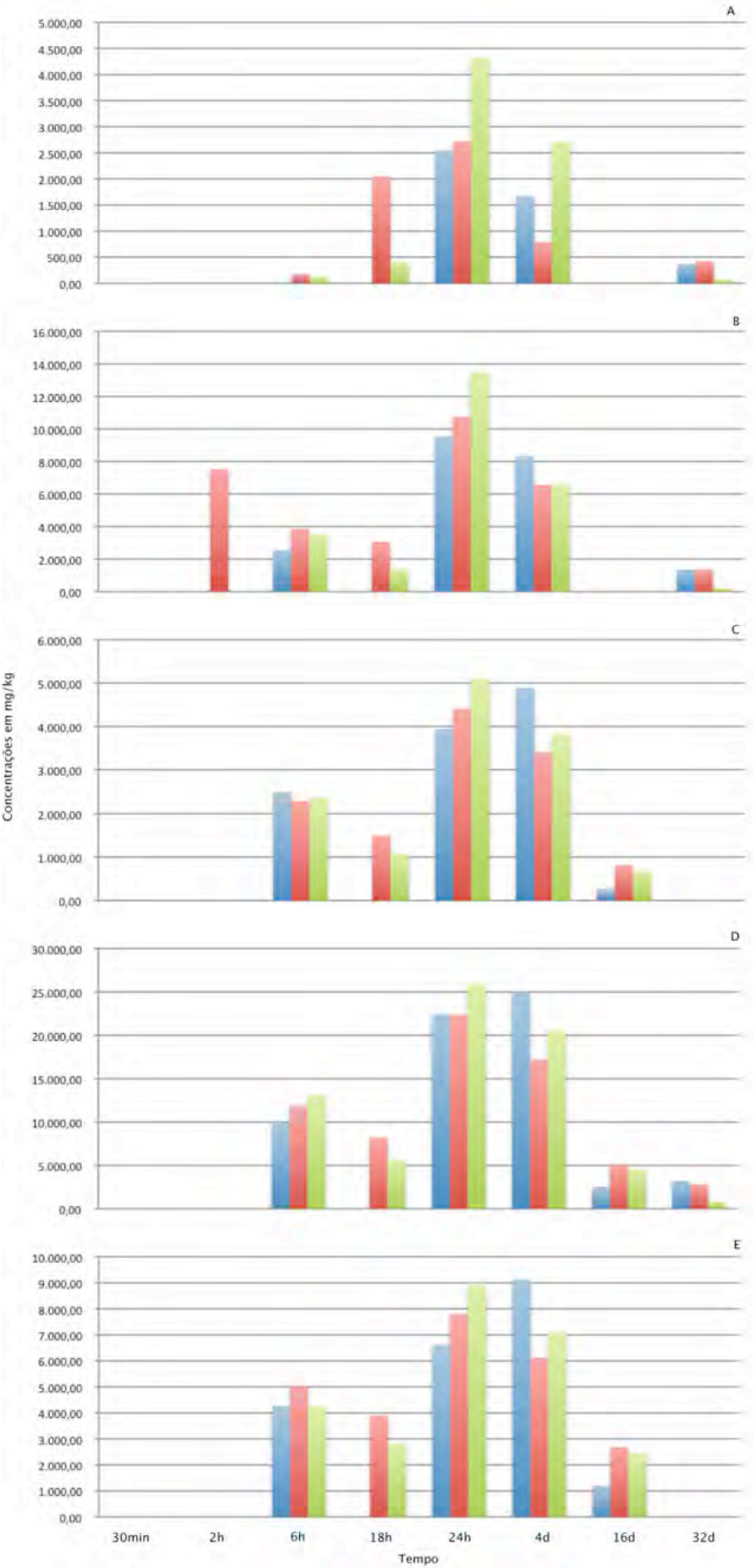

Figura 47 - Gráfico da variação da concentração de benzeno (A), tolueno (B), etilbenzeno (C), mp-xilenos (D) e oxileno (D) em função do tempo de desorção de GASOLINA e a amostra CA (Legenda: azul - rocha total, vermelho fração silte, verde - fração argila). 


\section{Benzeno, Tolueno, mp-Xilenos}

A Figura 48 apresenta as concentrações de benzeno, tolueno e mp-xilenos obtidas a partir do teste de desorção desses contaminantes puros pela rocha total e frações finas da amostra CA.

Os dados são relativamente dispersos, mas o comportamento da amostra contaminada com xilenos e tempo de desorção de 18 horas segue a tendência já observada para as amostras BP e JP, tendo teores menores em tempos mais curtos.

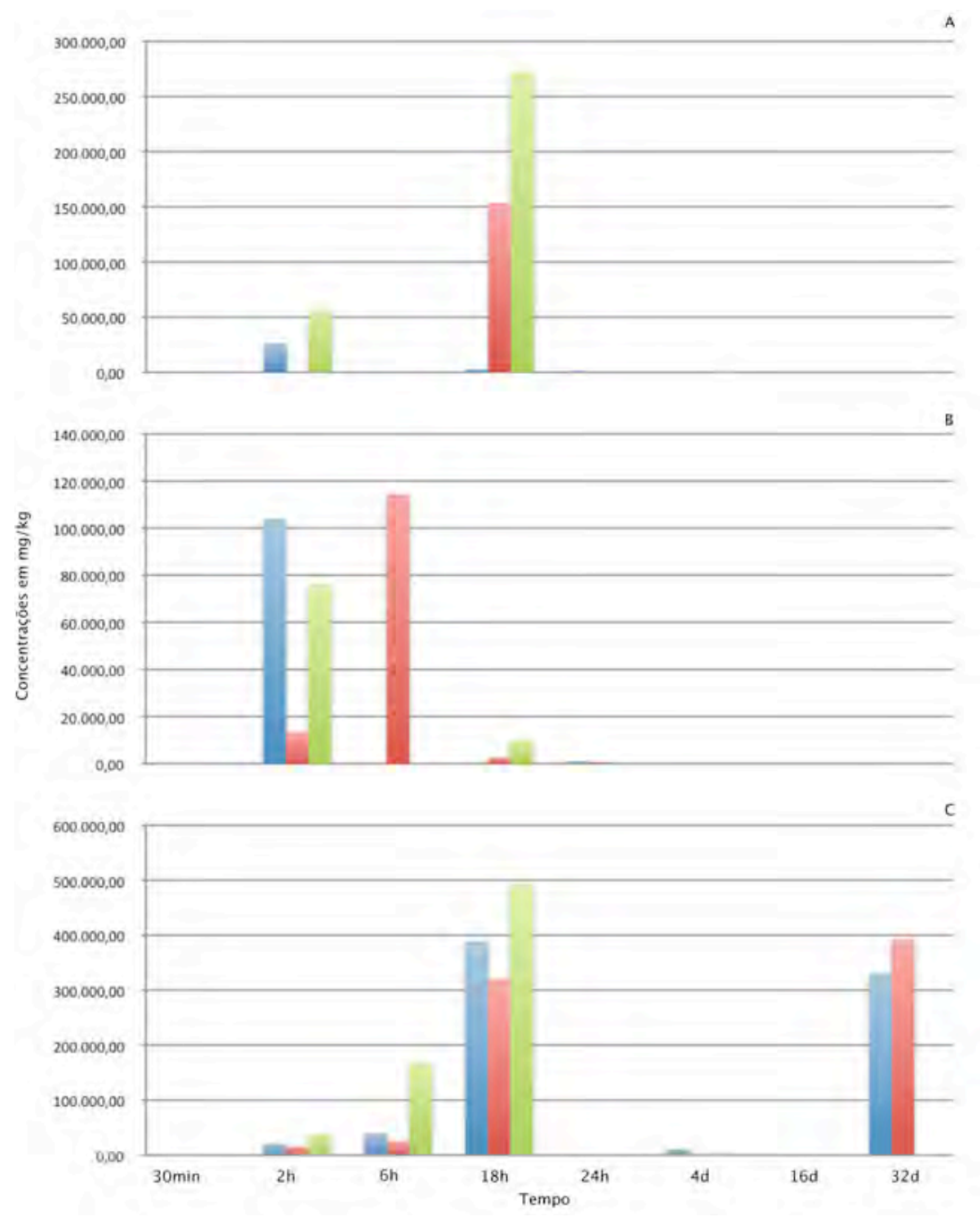

Figura 48 - Gráfico da variação da concentração de benzeno (A), tolueno (B) e mp-xilenos (C) em função do tempo de desorção do CONTAMINANTE PURO na amostra CA (Legenda: azul - rocha total, vermelho - fração silte, verde - fração argila).

\section{Discussão dos resultados}

\subsection{Características físico-químicas dos sedimentos}

Os dados granulométricos e mineralógicos obtidos para as três amostras de sedimentos da Formação Resende, provenientes de frentes de obras do Metrô na zona leste da Cidade de São Paulo, confirmam a relativa homogeneidade da unidade na Bacia de São Paulo, conforme anteriormente apontado por outros autores (e.g. Sant'Anna 1999). 
Coletadas em locais distintos, ainda que próximos, as três amostras são classificadas como argilitos a partir das análises granulométricas. As variações encontradas na composição dos clastos mostram que a amostra JP apresenta a maior concentração de argila (87\%), enquanto as amostras BP e CA contêm proporções semelhantes de argila (64\%), silte (31\%) e frações arenosas (5\%).

Quando observadas ao MEV, nota-se a estrutura maciça da matriz argilosa das três amostras (BP, JP, CA), sendo também nítido o caráter detrítico dos argilominerais, conforme evidenciado pelas bordas corroídas das placas, o que é atribuído ao transporte da área fonte até o sítio deposicional.

Os resultados da difração de raios X mostram ser bastante semelhantes as composições mineralógicas dos sedimentos estudados, com a presença de quartzo, mica, caulinita e argilomineral esmectítico nos difratogramas das amostras totais. As reflexões dos filossilicatos (caulinita, mica e esmectita) tornam-se mais evidentes nos difratogramas da fração argila, onde quartzo está ausente ou em proporção próxima ao limite de detecção do equipamento $(\sim 5 \%)$. Variações nas proporções desses filossilicatos são possivelmente existentes nas frações finas das três amostras, podendo ser apresentadas apenas qualitativamente.

A análise elementar de carbono revelou o baixo conteúdo em matéria orgânica dos sedimentos da Formação Resende, conforme esperado para esse tipo de material (e.g. Piwoni \& Banerjee 1989).

\subsection{Ensaios de sorção e desorção}

\subsubsection{Teste de absorção}

O ensaio de sorção por meio do teste de inchamento visou verificar a ocorrência do fenômeno de absorção, comum às esmectitas, após contato com compostos orgânicos. Das três amostras ensaiadas da Formação Resende, nenhuma apresentou sinais de inchamento. Os difratogramas de raios $\mathrm{X}$ das amostras usadas nesse teste mostraram que não houve variação significativa da distância interplanar, caracterizando a ausência de absorção dos contaminantes (gasolina comum e BTX) pelo argilomineral esmectítico. Entende-se que a entrada de moléculas orgânicas no espaço interlamelar pelo mecanismo da absorção provocaria aumento no espaçamento interlamelar (Parker \& Rae 1998). 0 comportamento absorvente de argilas esmectíticas naturais, de composição sódica e cálcica, tem sido há muito descrito na literatura. 0 uso dessas argilas data dos romanos antigos, que as empregavam como absorventes naturais de gorduras em tecidos, sendo denominadas de terras fuler (Robertson 1986, Santos 1989). No Brasil, os depósitos argilosos esmectíticos da Formação Tremembé, presente na porção central da Bacia de Taubaté, já foram classificados como terras fuler com poder descorante natural (Santos 1963), para óleos vegetais (Zandonadi 1972), ainda que de baixo rendimento (Santos 1989). Riccomini et al. (1994) atribuíram esse baixo rendimento à origem detrítica dos argilominerais esmectíticos da Formação Tremembé.

A gasolina brasileira tem a particularidade de possuir $25 \%$ de álcool etílico em sua composição (IBP 2009), o que segundo as regras de co-solvência, tornaria mais fácil a mistura entre água e gasolina. Entretanto, não foram observadas evidências desse mecanismo facilitador da entrada da gasolina na estrutura lamelar dos argilominerais esmectíticos da Formação Resende.

O espaço interlamelar das esmectitas é geralmente preenchido por alguns íons e água. A gasolina e demais compostos utilizados neste trabalho são imiscíveis ou muito pouco solúveis em água. Provavelmente, a água interlamelar forma um tampão, pois os 
compostos a repelem devido a seus valores de partição água-octanol, impedindo ou retardando a entrada da gasolina e demais compostos nesse espaço.

\subsubsection{Teste de absorção}

\section{Adsorção}

As altas concentrações de BTEX obtidas para rochas totais e frações finas confirmam que os sedimentos da Formação Resende foram contaminados e que a adsorção é o principal mecanismo de sorção atuante na interação dos contaminantes orgânicos (BTEX) com os argilominerais esmectíticos, durante os ensaios. De acordo com (Velde 1992), por esse mecanismo, o contaminante fica aderido à superfície das placas de argilominerais por ligações fracas do tipo van der Waals e pontes de hidrogênio, que permitem a adesão e soltura rápida dos compostos.

Os resultados do ensaio de adsorção mostram que há um padrão de distribuição dos teores de contaminantes (BTEX) em função do tempo de contato do composto orgânico com a amostra, seja rocha total ou frações finas. É possível distinguir quatro períodos principais, que se diferenciam pelos teores de contaminantes adsorvidos na rocha total e frações finas das três amostras (BP, JP, CA), conforme segue:

- entre 30 minutos e 2 horas com teores elevados;

- entre 6 horas e 18 horas com baixos teores;

- entre 24 horas e 4 dias com teores elevados;

- em 16 dias, com baixos teores, e 32 dias variável mas com tendência de elevação.

o comportamento identificado pode ser analisado em função de quatro fatores principais: a fração granulométrica e a composição mineralógica da amostra, o tempo de contato amostra/contaminante e o tipo de contaminante, conforme apresentado na Figura 49.

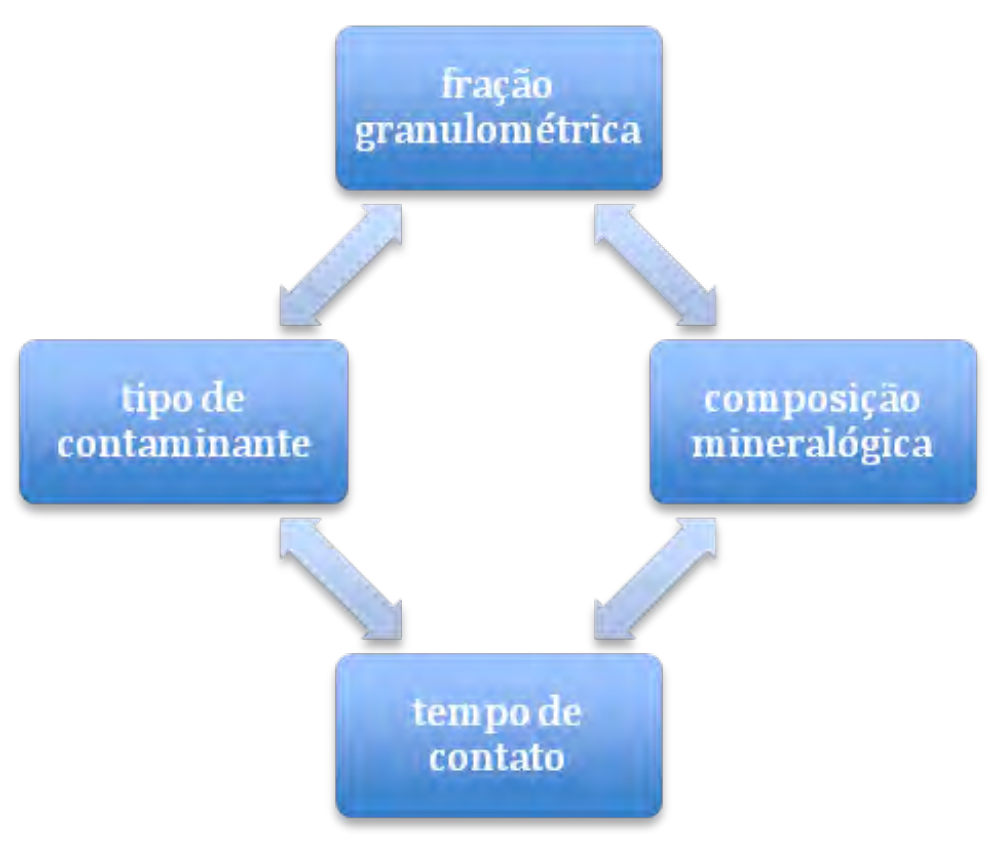

Figura 49 - Fatores considerados na avaliação integrada dos dados químicos. 
Os dados da Figura 34, Figura 37 e Figura 40 indicam que esse padrão ocorre independentemente do tipo de contaminante utilizado e da escala de teores medidos. 0 padrão é também independente da fração granulométrica, tendo sido observado:

- na rocha total e fração argila da amostra BP. A fração silte diferencia-se apenas por baixos teores no tempo de 30 minutos;

- nas frações finas (silte e argila) da amostra JP;

- na rocha total e fração silte da amostra CA. A fração argila não está plenamente caracterizada devido à ausência de alguns dados.

Adicionalmente, o fato de o padrão ter sido observado na fração silte das três amostras (BP, JP, CA) e na fração argila das amostras BP e JP indica que diferenças mineralógicas quaisquer entre as amostras não influenciaram essa variação. Assim, esse padrão pode ser relacionado ao processo de sorbância, no qual o tempo de contato entre a amostra e o contaminante tem importância fundamental. Estudos com amostras de solos e sedimentos superficiais e subsuperficiais (e.g. Karickhoff et al. 1979, Piwoni \& Banerjee 1989, Donahue et al. 1999) já apontaram o papel controlador do tempo de contato amostra/contaminante na sorção e desorção. Nesse estudo, não foi considerada a água intergranular do sedimento, pois essa foi eliminada no processamento das amostras. Em condições naturais, acredita-se que a água intergranular do sedimento na zona vadosa causaria variações, e menor homogeneidade nos tempos de adsorção dos compostos, pois a interação com os argilominerais seria muito mais complexa pelo mecanismo descrito por Parker \& Rae (1998).

A rocha total e frações finas das três amostras da Formação Resende (BP, JP, CA) seguem, de modo geral, o padrão descrito acima, o qual é bem observado na Figura 34. No entanto, os gráficos logarítmicos (Figura 35, Figura 38 e Figura 41) mostram que a maior variação ocorre na fração silte, que exibe oscilação dos teores de BTEX ao longo de todo o período de tempo analisado (30 minutos a 32 dias). Em todos os tempos de contato com o contaminante, registram-se oscilações de cerca de uma ordem de grandeza, o que pode dever-se ao caráter menos reativo do silte, em função da menor proporção de partículas finas, e facilidade de liberação dos orgânicos adsorvidos. Por outro lado, a fração argila apresenta oscilação das concentrações principalmente em curtos períodos de tempo de contato com o contaminante, em geral até 18 horas, e sempre inferiores a uma ordem de grandeza. A partir de 24 horas a concentração tende a se estabilizar para TEX e segue tendência de aumento para benzeno.

A análise e interpretação da variação dos teores de BTEX podem ser também realizadas para conjuntos de resultados relacionados, sem perda significativa de informação, evitando a interpretação do dado individual e minimizando a influência de dados incompletos. Assim, na Tabela 7 são apresentados os teores médios dos compostos BTEX obtidos para rocha total e frações finas (silte e argila) de cada amostra (BP, JP, CA) contaminada com gasolina e ensaiada pelo teste de adsorção. Os teores médios representam a média aritmética simples das concentrações de BTEX obtidas para todos os tempos de ensaio (30 minutos a 32 dias). 0 gráfico da Figura 50 apresenta as médias da Tabela 7 de forma que comparações entre as concentrações de contaminantes adsorvidos nas amostras BP, JP e CA possam ser discutidas. 
Tabela 7 - Teores médios de BTEX ( $\mathrm{mg} / \mathrm{kg}$ ) obtidos a partir do teste de adsorção com gasolina.

\begin{tabular}{ccccccc}
\hline \multicolumn{2}{c}{ Amostra } & Benzeno & Tolueno & Etilbenzeno & mp-Xilenos & o-Xileno \\
\hline \multirow{4}{*}{ BP } & Rocha total & $2.556,45$ & $7.049,90$ & $2.486,28$ & $12.997,13$ & $4.752,61$ \\
& Silte & $3.313,45$ & $6.323,76$ & $2.315,13$ & $13.133,12$ & $4.381,81$ \\
& Argila & $3.484,71$ & $8.328,81$ & $2.986,22$ & $17.473,53$ & $5.622,56$ \\
\hline \multirow{2}{*}{ JP } & Rocha total & $2.405,80$ & $6.929,12$ & $2.557,57$ & $13.329,89$ & $4.811,10$ \\
& Silte & $2.155,66$ & $5.902,98$ & $2.246,70$ & $11.996,99$ & $4.148,89$ \\
& Argila & $3.764,64$ & $7.796,20$ & $2.691,07$ & $14.284,12$ & $5.056,64$ \\
\hline \multirow{2}{*}{ CA } & Rocha total & $2.545,88$ & $5.567,52$ & $2.007,26$ & $10.789,13$ & $3.820,46$ \\
& Silte & $1.565,83$ & $5.227,53$ & $2.042,27$ & $10.839,53$ & $3.763,04$ \\
& Argila & $3.991,82$ & $8.650,70$ & $3.066,23$ & $17.318,05$ & $5.911,05$ \\
\hline
\end{tabular}

Os dados analíticos mostram-se geralmente consistentes e coerentes, sendo possível a discussão de comportamentos comuns a todas as amostras:

- benzeno e etilbenzeno apresentam-se com concentrações menores, em um intervalo bastante próximo, enquanto tolueno e xilenos ocorrem com concentrações mais elevadas na rocha total e frações finas das três amostras da Formação Resende contaminadas com gasolina. Como já apontado na apresentação dos dados (item 6.2), em ordem decrescente de teores adsorvidos, encontram-se mp-xilenos, com as maiores concentrações na rocha total e frações finas, seguidos de tolueno, o-xileno, benzeno e etilbenzeno. Esse comportamento é atribuído às características físico-químicas dos contaminantes. Esse comportamento reflete, provavelmente, o fato dos xilenos e tolueno serem compostos orgânicos menos voláteis (Tabela 4) e estarem em maior quantidade que o benzeno na gasolina (Tabela 3).

- as três amostras (BP, JP, CA) adsorveram cada contaminante em quantidades com a mesma ordem de grandeza, indicando que, apesar de diferenças granulométricas e mineralógicas locais, esses sedimentos comportam-se na média da mesma forma, como reflexo de sua homogeneidade em pequena escala. Nesse sentido, os teores próximos de benzeno na rocha total das três amostras (BP, JP, CA) sugerem que sua adsorção é controlada mais fortemente pelas características do composto, principalmente sua alta volatilidade, do que pelas propriedades do material, uma vez que a maior porcentagem de argila na amostra JP não resultou em diferença no teor adsorvido. Os demais contaminantes (TEX) são adsorvidos na mesma ordem de grandeza, mas em quantidades maiores pela rocha total das amostras BP e JP e em menor teor pela rocha total da amostra CA. Estes compostos apresentam menor volatilidade, permitindo maior interação com o material, de forma que as características destes também influem nos teores adsorvidos (Figura 50).

- em geral, a fração silte adsorve a menor concentração de contaminante (BTEX), quando comparada a rocha total e argila. Isto reflete a retirada de argilominerais da fração silte na etapa de pipetagem. Adicionalmente, nota-se que a fração silte das amostras BP, JP e CA adsorvem, nessa ordem, teores decrescentes de BTEX. Isto pode ser devido a diferenças mineralógicas entre as frações silte das amostras. A fração silte da amostra CA contém as menores quantidades de esmectita, mica e caulinita, o que justifica os baixos teores de BTEX adsorvidos. A fração silte da amostra JP contém a maior quantidade de esmectita e quantidades médias de mica e caulinita favorecendo a alta adsorção. A fração silte da amostra BP contém quantidade média de esmectita e maiores quantidades de mica e caulinita, minerais que também podem colaborar para a reatividade do material no processo sorção, elevando os teores adsorvidos. 
- a fração argila das três amostras (BP, JP, CA) adsorve as maiores concentrações de BTEX, quando comparada à rocha total e fração silte, que adsorvem concentrações menores. Isto reflete a concentração das partículas de argila na etapa de pipetagem e a maior capacidade de interação dos argilominerais com os compostos orgânicos. A fração argila das amostras BP, JP e CA mostra, nessa ordem, teores crescentes na adsorção de benzeno, o que pode dever-se à quantidade crescente de esmectita nessas frações, sendo esse o argilomineral que teria maiores condições de interagir com esse composto volátil. Para os demais compostos (TEX), a fração argila da amostra JP adsorve as menores concentrações, quando comparada à fração argila das amostras BP e CA, que adsorve concentrações maiores. Essa diferença pode ser devida às maiores quantidades de mica e caulinita na fração argila da amostra BP e de esmectita e mica na argila da amostra CA, enquanto na amostra JP as quantidades inferiores de esmectita, mica e caulinita respondem, provavelmente, pela menor adsorção de orgânicos.

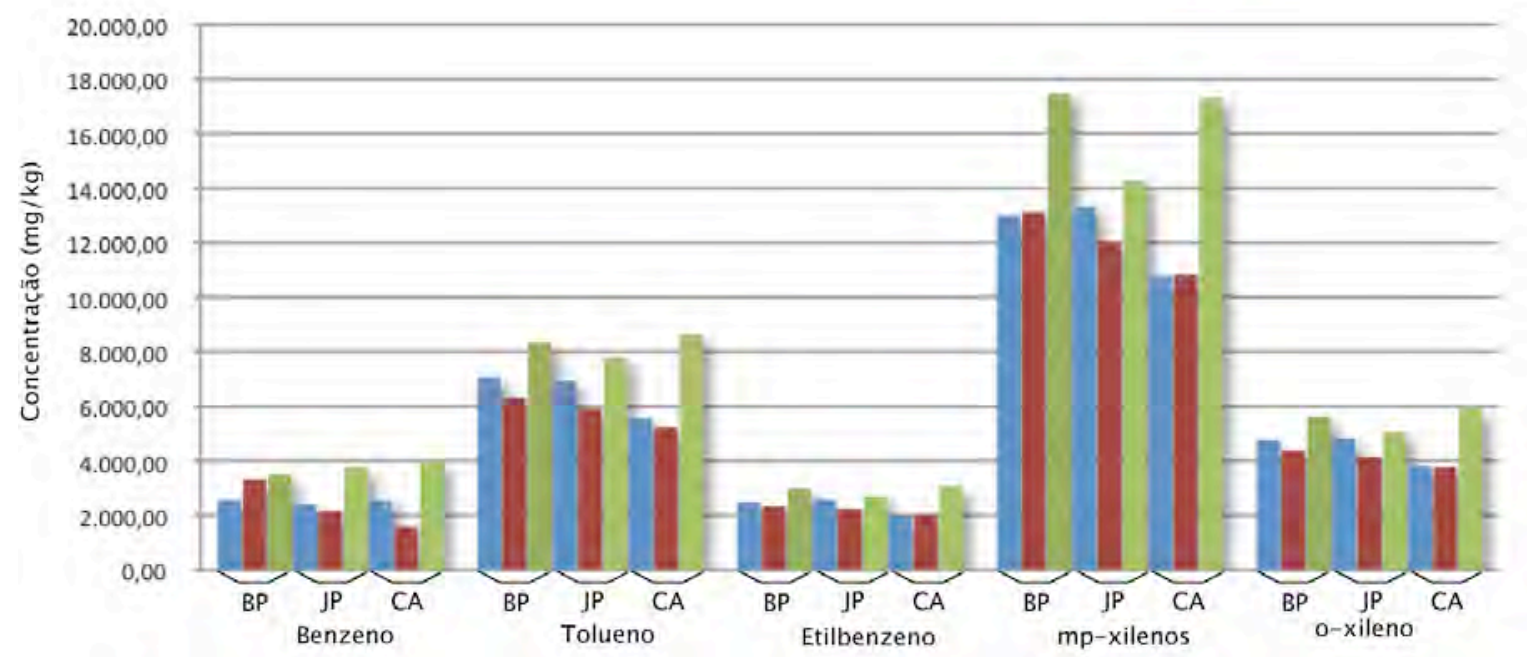

Figura 50 - Gráfico dos teores médios de BTEX obtidos a partir do teste de adsorção com a rocha total e frações finas (silte e argila) dos argilitos da Formação Resende contaminados por gasolina (Legenda: azul - rocha total, vermelho - fração silte, verde - fração argila).

A Figura 51 apresenta o teor médio de BTEX adsorvido na rocha total e frações finas das amostras ensaiadas. De modo geral, observa-se que os sedimentos apresentam comportamento comum, com concentrações de BTEX mais elevadas na fração argila e inferiores na fração silte e rocha total.

As amostras BP e CA apresentam o mesmo tipo de variação das concentrações de BTEX, com diferenças significativas entre a fração argila e a rocha total, com valores entre 5.000 e $7.500 \mathrm{mg} / \mathrm{kg}$ na amostra BP, e 4.500 e $7.900 \mathrm{mg} / \mathrm{kg}$ na amostra CA. Esse comportamento deve-se ao fato das amostras BP e CA apresentarem distribuições granulométricas muito semelhantes, com $94 \%$ de materiais pelíticos, sendo $64 \%$ de argila e $36 \%$ de silte. Esse menor volume de argila na rocha total implica em uma diferença maior nos teores quando a fração argila é concentrada, o que justifica a distribuição das concentrações de BTEX na Figura 51. Das três amostras ensaiadas, a amostra JP tem menor variação de teores $(5.300$ a $6.800 \mathrm{mg} / \mathrm{kg}$ ) entre a rocha total e fração argila, o que é atribuído à maior homogeneidade de sua granulação, que compreende $96 \%$ de materiais pelíticos, sendo $87 \%$ argila e apenas $9 \%$ silte. A concentração média de BTEX mais elevada na argila, seguida da rocha total e fração silte (argila>rocha total $>$ silte) é diretamente associada ao volume de argila no sedimento. 
Comparando-se o volume de argila da amostra JP com o das amostras BP e CA, os 23\% de diferença refletem-se, respectivamente, em 13\% e 15\% de diferença no teor de BTEX adsorvido. Isto sugere que, em sedimentos contaminados, a quantidade de contaminantes (BTEX) adsorvidos na rocha total será controlada pela proporção de argila presente no material, de forma que quanto mais argiloso mais contaminante será adsorvido. Por outro lado, quando se avalia apenas a fração argila, nota-se que a maior quantidade de contaminante adsorvido é relacionada ao tipo de argilomineral predominante na fração, sendo a maior proporção de esmectita um fator favorável, como no caso da amostra CA.

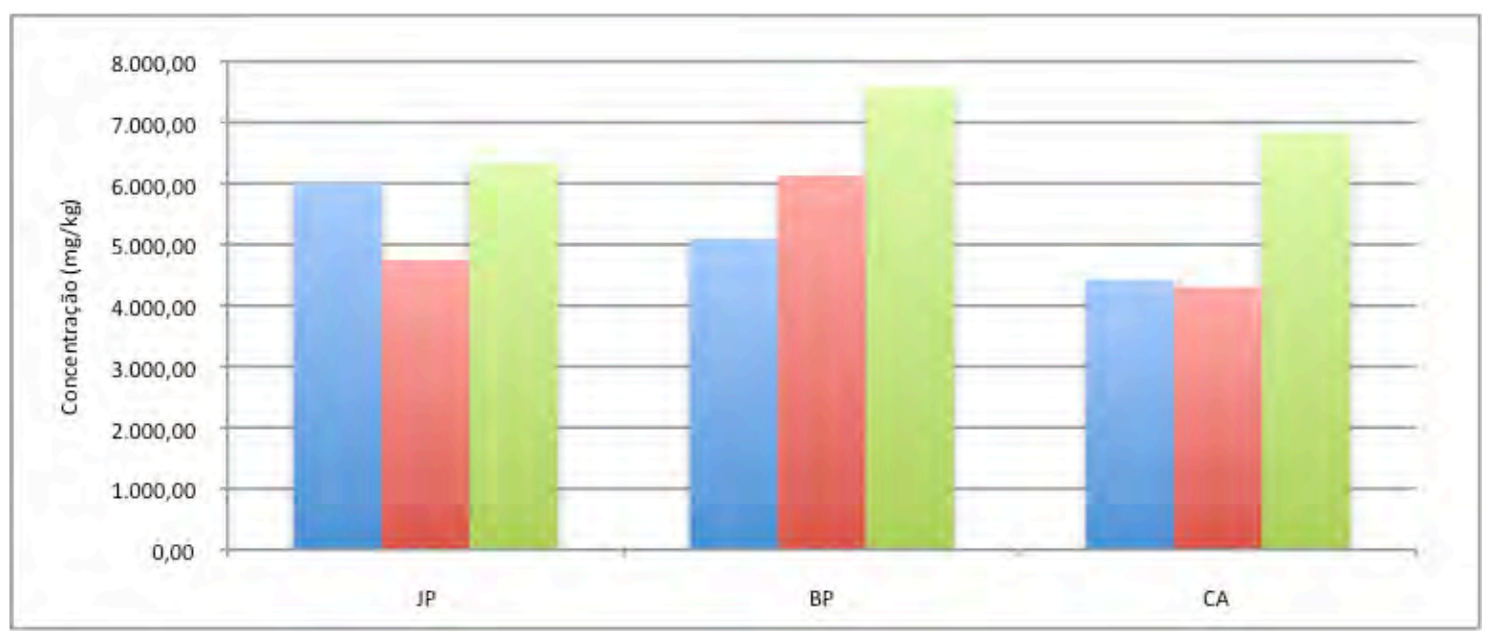

Figura 51 - Gráfico das médias dos teores de BTEX obtidos a partir do teste de adsorção com a rocha total e frações finas (silte e argila) dos argilitos da Formação Resende contaminados por gasolina (Legenda: azul - rocha total, vermelho - fração silte, verde - fração argila).

\section{Desorção}

O teste de desorção foi realizado para a rocha total e frações finas das três amostras (BP, JP, CA) contaminadas previamente com gasolina por 24 horas. A escolha desse tempo de contato amostra/contaminante para preparação das amostras mostrou-se acertada, pois o teor médio de BTEX obtido no teste de adsorção com rochas totais e frações finas para esse tempo de ensaio $(6.400 \mathrm{mg} / \mathrm{kg})$ representa bem a média do teor obtido em todos os tempos de ensaio $(5.972 \mathrm{mg} / \mathrm{kg})$.

As concentrações de BTEX obtidas para as rochas totais e frações finas das amostras $\mathrm{BP}$, JP e CA, indicam que os sedimentos permaneceram ainda contaminados após os tempos de desorção empregados (30 minutos a 32 dias).

Apesar dos dados incompletos, o ensaio de desorção permitiu observar que as concentrações de BTEX retidas nas amostras variam ao longo do tempo, sendo as mais altas retidas pela rocha total e frações finas após $24 \mathrm{~h}$ e 4 dias de desorção, provavelmente como um reflexo dos altos teores adsorvidos nesses tempos e não completamente desorvidos. Concentrações de BTEX inferiores ocorrem em tempos menores ( $6 \mathrm{~h}$ e $18 \mathrm{~h}$ ) e maiores (16 e 32 dias), como decorrência da pouca interação amostra/contaminante típica desses tempos, conforme indicado pelo teste de adsorção. Isto sugere que o tempo de $24 \mathrm{~h}$ de contato prévio entre a amostra e o contaminante serviu para garantir a contaminação do material. Entretanto, as quantidades de compostos orgânicos liberados e retidos na rocha total e frações finas em cada tempo de desorção, são um reflexo das interações amostra/contaminante características de cada tempo ensaiado, sendo esse (tempo) o fator controlador também na desorção. A diminuição significativa dos teores de BTEX aos 32 dias de desorção, conforme observado para a rocha total e frações finas das 
amostras BP, JP e CA (Figura 43, Figura 45, Figura 47), pode ser, tentativamente, interpretada como perda de orgânicos por desorção. Assim, o tempo necessário para a eliminação completa dos contaminantes é maior do que 32 dias se a forma de liberação for por evaporação.

Na Tabela 8 são fornecidos os teores médios de BTEX obtidos a partir do teste de desorção com os sedimentos da Formação Resende, na forma de rocha total e frações finas. Após desorção, as amostras BP e CA apresentam as maiores concentrações de BTEX ainda retidas na fração argila. Rocha total e fração silte apresentam, nessa ordem, os menores teores. As únicas exceções são as concentrações elevadas de xilenos na fração silte da amostra CA, quando comparadas à rocha total dessa amostra. Por outro lado, a amostra JP exibe comportamento distinto, com as maiores concentrações de BEX na rocha total, seguida da fração argila e da fração silte, indicando o caráter argiloso do sedimento e a retirada de argila na pipetagem da fração silte. A exceção é a concentração de tolueno maior na fração silte, seguido da rocha total e da fração argila. Outro aspecto distinto dessa amostra é a pequena variação dos teores de contaminantes entre a rocha total e a fração fina, o que também se explica pela grande quantidade de argila no sedimento.

Tabela 8 - Teores médios de BTEX ( $\mathrm{mg} / \mathrm{kg}$ ) obtidos a partir do teste de desorção com gasolina.

\begin{tabular}{ccccccc}
\hline \multicolumn{2}{c}{ Amostra } & Benzeno & Tolueno & Etilbenzeno & mp-Xilenos & o-Xileno \\
\hline \multirow{2}{*}{ BP } & Rocha total & $1.350,22$ & $3.286,54$ & $2.241,37$ & $9.834,33$ & $4.803,30$ \\
& Silte & $1.013,48$ & $3.283,84$ & $1.963,64$ & $8.865,28$ & $3.809,31$ \\
& Argila & $1.408,20$ & $5.530,91$ & $2.924,21$ & $11.765,25$ & $5.768,75$ \\
\hline \multirow{2}{*}{ JP } & Rocha total & $1.529,23$ & $5.448,67$ & $2.894,54$ & $12.606,39$ & $5.302,69$ \\
& Silte & $1.231,92$ & $5.527,33$ & $2.478,28$ & $11.269,51$ & $5.112,51$ \\
& Argila & $1.528,32$ & $5.046,69$ & $2.612,04$ & $11.786,00$ & $5.113,26$ \\
\hline \multirow{3}{*}{ CA } & Rocha total & 729,11 & $3.374,70$ & $2.127,90$ & $8.885,55$ & $3.630,98$ \\
& Silte & 482,36 & $2.131,93$ & $2.062,81$ & $8.937,84$ & $4.017,04$ \\
& Argila & 887,78 & $4.937,64$ & $3.406,33$ & $14.480,66$ & $7.162,76$ \\
\hline
\end{tabular}

A Figura 52 apresenta as médias da Tabela 8 de forma que outras comparações entre as concentrações de contaminantes desorvidos nas amostras BP, JP e CA possam ser efetuadas. Nesse gráfico, nota-se que:

- mp-xilenos são os compostos que restam com maior concentração após os tempos de desorção tanto na rocha total quanto nas frações finas das três amostras ensaiadas. Em ordem decrescente de teores, restam o-xileno, tolueno, etilbenzeno e benzeno. Esse comportamento é controlado pela volatilidade do composto, que no caso dos mp-xilenos é menor;

- a rocha total da amostra JP retém as maiores concentrações de BTEX, quando comparada à rocha total das amostras $\mathrm{BP}$ e CA, o que pode dever-se a sua composição mais argilosa, que retém mais contaminante;

- benzeno e etilbenzeno apresentam-se com teores menores na fração silte das três amostras (BP, JP, CA), quando comparada às respectivas rocha total e fração argila. Isso pode ser devido à mobilidade desses compostos e à menor proporção de partículas finas nessa fração, o que proporciona menor fixação dos compostos. Os demais compostos (TX) apresentam comportamento variável, reflexo, provavelmente, da maior proporção desses compostos na gasolina e das suas menores mobilidades; 
- a fração argila da amostra CA apresenta os maiores teores de etilbenzeno e xileno, provavelmente devido ao seu maior conteúdo em argilominerais esmectítico, quando comparado às frações argila das amostras BP e JP.

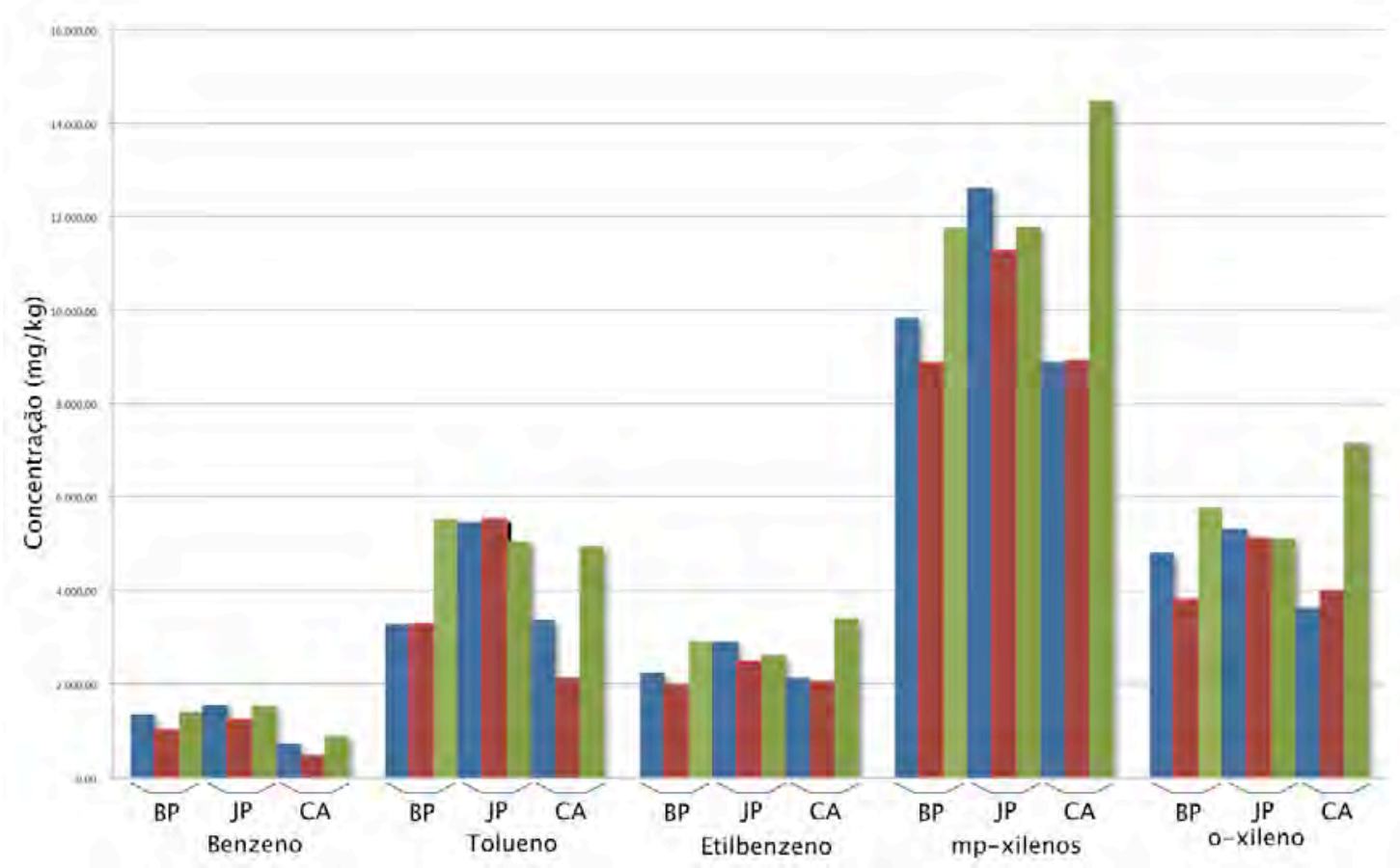

Figura 52 - Gráfico dos teores médios de BTEX obtidos a partir do teste de desorção com a rocha total e frações finas (silte e argila) dos argilitos da Formação Resende contaminados por gasolina (Legenda: azul - rocha total, vermelho - fração silte, verde - fração argila).

A Tabela 9 apresenta a diferença (em porcentagem) entre os teores médios de BTEX medidos a partir dos testes de adsorção e desorção com gasolina. Benzeno é o contaminante com maior variação de teores entre os ensaios de adsorção e desorção, com perda da ordem de $36 \%$ a $78 \%$, o que é esperado visto sua característica de alta volatilidade. 0 segundo contaminante com maior variação, o tolueno, registra perda entre $21 \%$ e $59 \%$. Uma exceção é a fração silte da amostra JP, que apresentou variação muito baixa de cerca de $6 \%$. Etilbenzeno tem variações menores, de até $15 \%$ de perda ou ganho de massa de contaminante. Mp-xilenos apresentam variações entre 5\% e 33\% e o-xileno apresenta variações de até $23 \%$ de ganho de massa de contaminante na amostra de desorção.

Tabela 9 - Diferença (em porcentagem) entre os teores médios de BTEX medidos nos testes de adsorção e desorção com gasolina.

\begin{tabular}{ccccccc}
\hline \multicolumn{2}{c}{ Amostra } & Benzeno & Tolueno & Etilbenzeno & mp-Xilenos & o-Xileno \\
\hline \multirow{4}{*}{ BP } & Rocha total & 47,18 & 53,38 & 9,85 & 24,33 & $-1,07$ \\
& Silte & 69,41 & 48,07 & 15,18 & 32,50 & 13,07 \\
& Argila & 59,59 & 33,59 & 2,08 & 32,67 & $-2,60$ \\
\hline \multirow{4}{*}{ JP } & Rocha total & 36,44 & 21,37 & $-13,18$ & 5,43 & $-10,22$ \\
& Silte & 42,85 & 6,36 & $-10,31$ & 6,06 & $-23,23$ \\
& Argila & 59,40 & 35,27 & 2,94 & 17,49 & $-1,12$ \\
\hline \multirow{2}{*}{ CA } & Rocha total & 71,36 & 39,39 & $-6,01$ & 17,64 & 4,96 \\
& Silte & 69,19 & 59,22 & $-1,01$ & 17,54 & $-6,75$ \\
& Argila & 77,76 & 42,92 & $-11,09$ & 16,38 & $-21,18$ \\
\hline
\end{tabular}


A Figura 53 apresenta os teores médios de BTEX nas amostras contaminadas por gasolina e ensaiadas pelo teste de desorção. Comparando-se o teor médio de BTEX obtido a partir do teste de adsorção para rocha total e frações finas das três amostras, com o teor médio de BTEX ainda retido nessas amostras após desorção, observa-se que esse último é cerca de $25 \%$ menor, o que demonstra a liberação dos compostos orgânicos no total dos tempos empregados.

Na Figura 53 é possível verificar que o comportamento das amostras BP, JP e CA se modifica em relação ao anteriormente visto nos ensaios de adsorção (Figura 52). No teste de adsorção das amostras BP e CA, a menor quantidade de argila nessas amostras amplificou as diferenças entre os teores adsorvidos na rocha total e fração argila. No teste de desorção, a fração argila das amostras BP e CA mantém as concentrações elevadas de BTEX, sendo seguida pela rocha total e silte (argila>rocha total $>$ silte). A menor diferença entre os teores de BTEX retidos na rocha total e fração argila parece ser devido à dificuldade de liberação desses compostos pela fração fina, inclusive daquela presente na rocha total. Na desorção, a amostra JP também apresenta comportamento contrário ao observado no teste de adsorção, com a fração argila exibindo as menores concentrações, seguida, em ordem crescente, pela fração silte e rocha total (rocha total $>$ silte>argila). Esse comportamento é atribuído à alta proporção de argila no sedimento, que permite a retenção de grande quantidade de contaminante na rocha total. É provável que parte da fração argila não totalmente retirada da fração silte na etapa de pipetagem tenha contribuído para o alto teor de contaminante retido na fração silte da amostra JP. Na Figura 53 nota-se que o volume de argila e o tipo de argilomineral predominante são os dois fatores controladores da quantidade de contaminantes retidos, respectivamente, na rocha total e na fração argila, após desorção, da mesma forma que controlam essa quantidade no teste de adsorção.

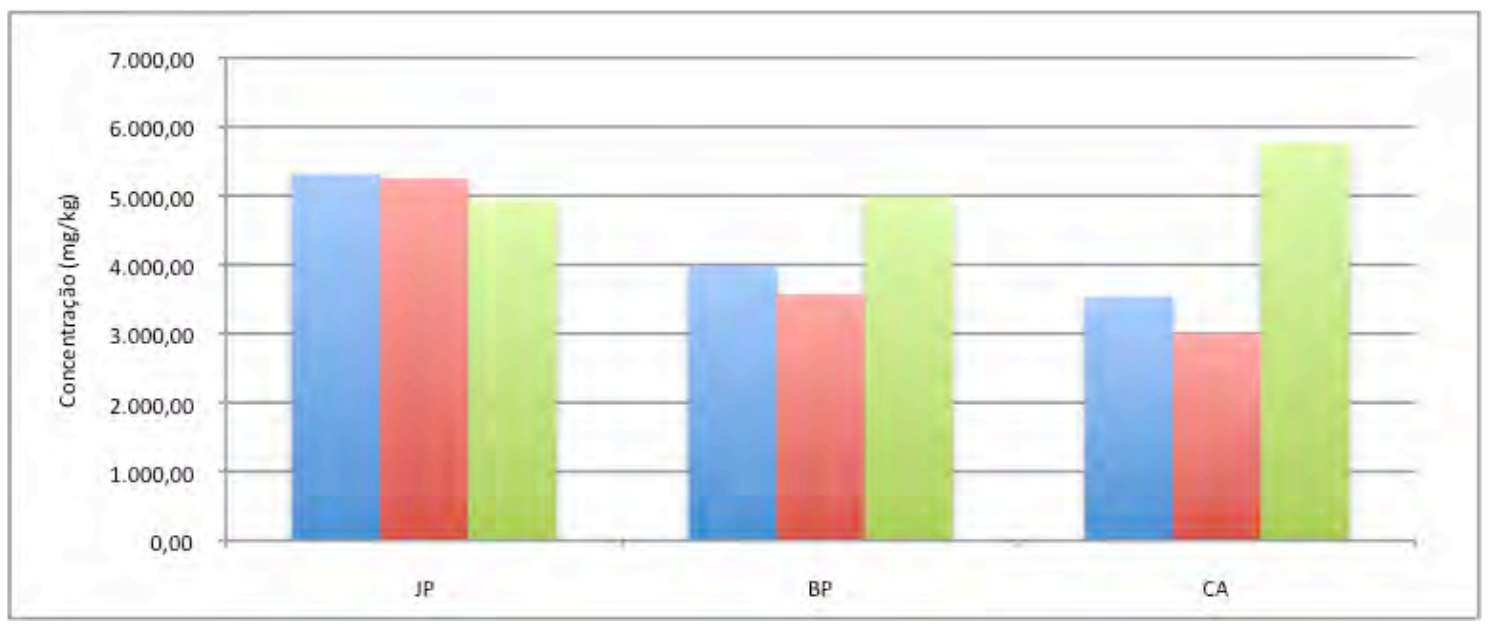

Figura 53 - Gráfico das médias dos teores de BTEX obtidos a partir do teste de desorção com a rocha total e frações finas (silte e argila) dos argilitos da Formação Resende contaminados por gasolina (Legenda: BP - argilito coletado na Rua Bom Pastor, JP - argilito coletado na Av. Juntas Provisórias, CA - argilito coletado na Rua Cavour).

\subsubsection{Testes de adsorção e desorção com BTX puros}

\section{Adsorção}

As amostras contaminadas com reagentes (BTX) puros nos ensaios de adsorção têm concentrações, em geral, 100 vezes maiores que as contaminadas com gasolina comum. De modo geral, esses altos teores de BTX obtidos nos ensaios de adsorção com compostos 
puros são devidos à pureza dos produtos, enquanto na gasolina suas proporções são menores.

Na descrição dos resultados (item 6.2), observou-se a ampla variação dos teores de BTX, tanto na rocha total quanto nas frações finas. No entanto, os dados da Tabela 10 mostram que os teores médios mantêm-se numa mesma escala, na casa de centena de milhar, exceto para o-xileno que são dispersos e pontuais.

As concentrações de BTX também apresentaram oscilação ao longo dos tempos de contato empregados, tendo, em geral, os menores valores às $6 \mathrm{~h}$ e $16 \mathrm{~h}$ e os maiores nos demais tempos ( $30 \mathrm{~min}$., $2 \mathrm{~h}, 18 \mathrm{~h}, 24 \mathrm{~h}, 4$ dias e 32 dias). Essa variação concorda com aquela encontrada no teste de adsorção com gasolina e parece confirmar que, quando visto em detalhe, o tempo de contato é o principal fator no controle da quantidade de contaminante adsorvido, em detrimento da fração granulométrica, composição mineralógica e tipo de contaminante.

A diferença entre os teores de benzeno obtidos nos testes de adsorção e de desorção atingem $98 \%$, com uma média de $76 \%$ de perda de massa de contaminante, o que é esperado pela alta volatilidade do composto e concorda com o resultado obtido a partir do teste de adsorção com gasolina. Para tolueno a média de perda de massa é de $50 \%$. Mpxilenos apresentam diferença média de $11 \%$, mas os dados apresentam grande variação de -85\% (os teores no ensaio de desorção são mais elevados que os do ensaio de sorção) a $54 \%$. As médias das concentrações de o-xileno são apresentadas, porém são os dados são pontuais e muito dispersos, não sendo considerados na análise.

Tabela 10 - Médias dos teores de BTEX (mg/kg) nas amostras contaminadas com compostos orgânicos (BTX) puros, para os ensaios de adsorção.

\begin{tabular}{cccccc}
\hline \multicolumn{2}{c}{ Amostra } & Benzeno & Tolueno & mp-Xilenos & o-Xileno \\
\hline \multirow{4}{*}{ BP } & Rocha total & $361.386,50$ & $322.108,37$ & $401.386,23$ & $6.811,90$ \\
& Silte & $272.633,01$ & $243.427,65$ & $402.873,91$ & - \\
& Argila & $218.660,05$ & $206.140,81$ & $346.288,85$ & - \\
\hline \multirow{2}{*}{ JP } & Rocha total & $297.618,76$ & $170.526,03$ & $227.264,59$ & $1.106,81$ \\
& Silte & $324.347,67$ & $276.463,28$ & $190.087,06$ & $6.568,44$ \\
& Argila & $309.246,26$ & $239.175,66$ & $360.897,62$ & $4.204,93$ \\
\hline \multirow{3}{*}{ CA } & Rocha total & $243.983,52$ & $69.760,33$ & $184.919,27$ & $102.384,82$ \\
& Silte & $268.246,27$ & $120.872,81$ & $160.258,15$ & $4.040,61$ \\
& Argila & $345.864,61$ & $134.973,83$ & $196.596,54$ & 861,40 \\
\hline
\end{tabular}

Desorção

De modo geral, os teores de BTX obtidos nos ensaios de desorção com compostos puros são maiores do que os obtidos no teste com gasolina, o que também se deve à pureza dos produtos, enquanto na gasolina suas proporções são menores. As concentrações são em média 10 vezes maiores do que nas amostras contaminadas por gasolina.

A análise das concentrações de BTX retidas na rocha total e frações finas das três amostras (BP, JP, CA) ao longo do tempo de desorção mostrou, no conjunto, que os mais altos valores ocorrem após $2 \mathrm{~h}, 18 \mathrm{~h}$ e 32 dias e os menores são encontrados após $6 \mathrm{~h}, 4$ dias e 16 dias. A despeito da ausência de vários dados, essa oscilação parece corroborar a interpretação de que as quantidades de compostos orgânicos liberados e retidos na rocha total e frações finas em cada tempo de desorção é um reflexo das interações que ocorrem em cada tempo, sendo esse o fator controlador.

A Tabela 11 apresenta as médias de teores de contaminantes puros nos ensaios de desorção. Nota-se que a variabilidade dos dados é maior, o que se justifica em função dos dados serem menos completos que os obtidos no teste de desorção com gasolina. Os 
teores de o-xileno são apresentados, mas, assim como nos ensaios com gasolina, são dados dispersos e pontuais.

$\mathrm{Na}$ amostra JP os teores dos contaminantes são maiores que os das amostras BP e CA, o que parece ser reflexo de sua maior concentração de argilas. Os teores dos contaminantes podem ser relacionados à sua pressão de vapor, sendo que o benzeno, com a maior pressão de vapor, é o contaminante com menores teores. 0 tolueno apresenta teores intermediários e os mp-xilenos teores superiores. Esse comportamento é observado também nas amostras contaminadas com gasolina.

\begin{tabular}{|c|c|c|c|c|c|}
\hline & Amostra & Benzeno & Tolueno & Mp-xilenos & O-xileno \\
\hline \multirow{3}{*}{ BP } & Rocha total & $13.134,77$ & $97.925,15$ & $419.091,78$ & 889,37 \\
\hline & Silte & $10.178,20$ & $86.596,59$ & $184.441,31$ & $2.840,77$ \\
\hline & Argila & $13.691,20$ & $190.033,06$ & $252.907,25$ & $2.573,96$ \\
\hline \multirow{3}{*}{$J P$} & Rocha total & $91.150,59$ & $174.029,64$ & $229.022,21$ & - \\
\hline & Silte & $251.750,91$ & $39.150,03$ & $351.575,18$ & $3.792,73$ \\
\hline & Argila & $125.004,70$ & $190.294,46$ & $522.255,18$ & $10.754,61$ \\
\hline \multirow{3}{*}{ CA } & Rocha total & $4.394,81$ & $26.380,65$ & $132.069,85$ & 423,82 \\
\hline & Silte & $30.751,36$ & $21.917,45$ & $125.588,28$ & - \\
\hline & Argila & $82.331,97$ & $21.689,44$ & $141.482,36$ & - \\
\hline
\end{tabular}

A Tabela 12 apresenta, em porcentagem, a diferença entre os teores médios dos compostos puros nos ensaios de adsorção e desorção. Para benzeno a variação média na amostra JP é de 50\%, na amostra BP é 95\% e 87\%na amostra CA. Tolueno tem variação de $34 \%$ na amostra JP, 47\% na amostra BP e 75\% na amostra CA. Mp-xilenos apresentam variação de $-43 \%$ (teores mais elevados na desorção do que na sorção) na amostra JP, enquanto a variação nas amostras BP e CA é de $25 \%$.

Tabela 12 - Diferença (em porcentagem) entre os teores médios de BTX medidos nos testes de sorção e desorção com compostos puros.

\begin{tabular}{cccccc}
\hline \multicolumn{2}{c}{ Amostra } & Benzeno & Tolueno & Mp-xilenos & O-xileno \\
\hline \multirow{4}{*}{ BP } & Rocha total & 96,37 & 69,60 & $-4,41$ & 86,94 \\
& Silte & 96,27 & 64,43 & 54,22 & - \\
& Argila & 93,74 & 7,81 & 26,97 & - \\
\hline \multirow{4}{*}{ JP } & Rocha total & 69,37 & $-2,05$ & $-0,77$ & - \\
& Silte & 22,38 & 85,84 & $-84,95$ & 42,26 \\
& Argila & 59,58 & 20,44 & $-44,71$ & $-155,76$ \\
\hline \multirow{4}{*}{ CA } & Rocha total & 98,20 & 62,18 & 28,58 & 99,59 \\
& Silte & 88,54 & 81,87 & 21,63 & - \\
& Argila & 76,20 & 83,93 & 28,03 & - \\
\hline
\end{tabular}




\section{Conclusões}

Este trabalho teve por objetivo maior o estudo laboratorial da interação, de sorção e desorção, dos hidrocarbonetos gasolina comercial, benzeno, tolueno e xilenos (BTX) com os argilominerais esmectíticos da Formação Resende, no contexto da zona vadosa, na Bacia de São Paulo. Objetivos específicos foram propostos, incluindo a caracterização das três amostras argilosas coletadas na zona leste da Cidade de São Paulo e utilizadas nos testes laboratoriais, e o emprego de testes de absorção, adsorção e desorção com gasolina comum e compostos orgânicos puros (BTX) em rocha total e frações finas (silte e argila).

As três amostras utilizadas nesse trabalho foram classificadas como argilitos, com variações das proporções de silte e argila na sua distribuição granulométrica, e composição mineralógica limitada a quartzo, mica, caulinita e argilomineral esmectítico.

No estudo da sorção, as amostras foram submetidas a teste de inchamento, sendo que nenhuma delas apresentou absorção dos compostos orgânicos, uma vez que não foi observada variação na distância interplanar do argilomineral esmectítico.

Os testes de adsorção e desorção procuraram caracterizar a interação dos hidrocarbonetos com os argilominerais esmectíticos variando-se o tempo de exposição das amostras aos contaminantes. De modo geral, os resultados obtidos nos testes de absorção e desorção com contaminantes puros corroboraram as interpretações desses testes realizados com gasolina.

Os dados obtidos permitiram interpretar que o mecanismo de sorbância predominante é a adsorção, um processo regido por ligações fracas que permitem grande mobilidade dos compostos. A variação dos teores ao longo do tempo de contato evidencia que a interação da amostra com o contaminante é dinâmica. Há momentos distintos de sorbância, com variação significativa e bem representada dos teores adsorvidos, e que essas fases ocorrem independentemente da granulometria ou mineralogia das amostras, sendo o tempo de contato o fator controlador das ordens de grandeza dos teores de BTEX adsorvidos e desorvidos nos sedimentos argilosos. Quando analisados de forma mais abrangente, os dados mostraram que:

- na rocha total, a quantidade de contaminantes adsorvidos, ou retidos após desorção, é regida pelo volume de argila presente no sedimento, onde aqueles com maior conteúdo de argila apresentam maiores teores de contaminantes;

- a fração argila tem maior tendência de acumular os contaminantes, quando comparada a fração silte;

- o teor de contaminantes adsorvidos, ou retidos após desorção, na fração argila dependerá do tipo de argilomineral predominante, sendo os esmectíticos aqueles com maior interação com os compostos orgânicos;

- as propriedades físicas dos compostos orgânicos influenciam nos teores adsorvidos, de modo que os compostos mais móveis (com maior volatilidade) tendem a ocorrem em menor concentração.

0 estudo com maiores tempos de contato contaminante/amostra podera trazer novas características desse fenômeno.

Os resultados obtidos para os ensaios com amostras puras se mostraram efetivos para a caracterização do comportamento. 0 estudo de outras substâncias contaminantes com essa metodologia pode ser uma interessante linha de pesquisa.

A avaliação de casos reais com a metodologia aqui utilizada, mesmo que simplificada, é viável, e pode alimentar modelos numéricos de contaminação, ou orientar sobre as melhores metodologias de remediação a serem utilizadas. 


\section{Referências Bibliográficas}

Almeida, F.F.M. 1958. O Planalto Paulistano. In: A Cidade de São Paulo. São Paulo, Associação dos Geógrafos Brasileiros, p.113-167.

Almeida, F.F.M. 1976. Estruturas do Pré-Cambriano Inferior Brasileiro. In: Congresso Brasileiro de Geologia, 29, Ouro Preto. SBG, Ouro Preto, Abstracts, p.201-202.

Almeida, F.F.M.; Amaral, G.; Cordani, U.G.; Kawashita, K. 1973. The Precambrian evolution of the South America cratonic margins. In: Nairm, A.E.M. \& Stehli, E.G. (eds). Ocean Basins and Margins. Plenum Publ. Co, New York, p.411-446.

Alvarez, P.J. 2004. Princípios e aplicações da bioremediação de BTEX. In: Moeri, E.; Coelho, R.; Marker, A. (eds). Remediação e revitalização de áreas contaminadas. Signus, São Paulo, p.93-107.

Amador, E.S. 1975. Estratigrafia e sedimentação da Bacia de Resende, RJ. Anais da Academia Brasileira de Ciências, 47:181-225.

ANP - Agência Nacional do Petróleo. 2001. Portaria n 309 de 27 de dezembro de 2001.

ASTM - American Society for Testing and Materials. 2009. Procedimento ASTM E1195-01.

Atterberg, A. 1905. Die rationelleklassificationdersande und kiese. Chem. Zeitschr, 29: 195-198.

Bailey, S.W. 1980. Summary of recommendations of AIPEA Nomenclature Committee. Am. Mineralogist, 65:1-7.

Bergaya, F. \& Lagaly, G. 2006. General Introduction: Clays, Clay Minerals, and Clay Science. In: Bergaya, F.; Theng, B.K.G.; Lagaly, G. (eds). Handbook of Clay Science. Elsevier, Amsterdam. Developments in Clay Science, vol. 1, p.1-19.

Brigatti, M.F.; Galan, E.; Theng, B.K.G. 2006. Structures and Mineralogy of Clay. In: Bergaya, F.; Theng, B.K.G.; Lagaly, G. (eds). Handbook of Clay Science. Elsevier, Amsterdam. Developments in Clay Science, vol. 1, p.19-87.

Brindley, G.W. \& Brown, G. 1980. Crystal structures of clay minerals and their X-ray identification. Mineralogical Society, London, 495p.

Caillere, S.; Hénin, S.; Rautureau, M. 1982. Minéralogie des argiles. Masson, Paris, 184p.

Calabrese, E.J. \& Kostecki, P.T. 1993. Principles and practices for petroleum contaminated soils. Lewis, Florida, 658p.

CETESB - Companhia de Tecnologia de Saneamento Ambiental. 2001a. Ficha de informação de produto químico. Benzeno. Website (http://www.cetesb.sp.gov.br)

CETESB - Companhia de Tecnologia de Saneamento Ambiental. 2001b. Ficha de informação de produto químico. Tolueno. Website (http://www.cetesb.sp.gov.br)

CETESB - Companhia de Tecnologia de Saneamento Ambiental. 2001c. Ficha de informação de produto químico. Xileno. Website (http://www.cetesb.sp.gov.br)

CETESB - Companhia de Tecnologia de Saneamento Ambiental. 2008. O Gerenciamento de Áreas Contaminadas no Estado de São Paulo. Website (http://www.cetesb.sp.gov.br/Solo/areas_contaminadas/relacao_areas.asp)

Chamley, H. 1989. Clay sedimentology. Springer, Berlin, 623p. 
Coimbra, A.M.; Riccomini, C.; Melo, M.S. 1983. A Formação Itaquaquecetuba: evidências de tectonismo no quaternário paulista. In: Simpósio Regional de Geologia, IV, São Paulo. SBG, São Paulo, Atas, p. 253-266.

Cole, G.M. 1994. Assessment and remediation of petroleum contaminated sites. Lewis, Florida, $360 p$.

Corseuil, H.X. \& Fernandes, M. 1999. Efeito do etanol no aumento da solubilidade de compostos aromáticos presentes na gasolina brasileira. Rev. Eng. Sanitária $e$ Ambiental, 4: 71-75.

Dixon, J.B. \& Weed, S.B. 1989. Minerals in soil environments. SSSA, Wisconsin, 1244p.

Donahue, R.B.; Lee Barbour, S.; Headley, J.V. 1999. Diffusion and adsorption of benzene in clay. Can. Geotech. J., 36:430-442.

Dragun, J.; Gambino, R.; Kuhn, W. 1996. Coloration changes of geologic media after addition of gasoline, diesel fuel, and ethylbenzene. Journal of Soil Contaminations, 5(1):1-8.

Englert, C.J.; Kenzie, E.J.; Dragun, J. 1993. Bioremediation of petroleum products in soil. In: Calabrese, E.J. \& Kostecki, P.T. (eds). Principles and practices for petroleum contaminated soils. Lewis, Florida, p.111-129.

EPA - Environmental Protection Agency. 1997. Analysis of selected enhancements for soil vapor extraction. EPA - 542-R-97-007. Website (www.epa.gov)

EPA - Environmental Protection Agency. 2009. EPA 8021B Aromatic and Halogenated Volatiles by Gas Chrimatography Using Photoionization and/or Eletrolytic Conductivity Detectors - Method. Website (www.epa.gov)

Fetter, C.W. 1999. Contaminant hydrogeology. Prentice-Hall, New Jersey, 500p.

Finotti, A.R. 2003. Efeitos da transferência de massa na relação matemática entre espessuras real e aparente em fase livre de gasolina com etanol nas contaminações subterrâneas. Porto Alegre, 189p. (Tese de doutoramento, Instituto de Pesquisas Hidráulicas, Universidade Federal do Rio Grande do Sul).

Folk, R.L. 1974. Petrology of sedimentary rocks. Hemphill, Austin, 182p.

Furtado, M. 2005. Remediação de solos. Química \& Derivados, p.26-45.

Goenopawiro, K.S. 1997. Diagênese dos arenitos terciários da Bacia de Taubaté - SP. Rio Claro, 149p. (Dissertação de mestrado, Instituto de Geociências e Ciências Exatas, Universidade Estadual Paulista).

Guggenheim, S. \& Martin, R.T. 1995. Definition of clay and clay mineral. Joint report of AIPEA and CMS Nomenclature Committees. Clay Minerals, 30:257-259.

Hasui, Y. \& Sadowski, G.R. 1976 Evolução geológica do Pré-Cambriano na região sudeste do Estado de São Paulo. Rev. Bras. Geoc., 6:180-200.

IBP - Instituto Brasileiro de Petróleo Gás e Biocombustíveis. 2009. Website (http://www.ibp.org.br)

IPT - Instituto de Pesquisas Tecnológicas do Estado de São Paulo. 1986. Tectônica e sedimentação cenozóica na área da soleira entre as bacias de São Paulo e Taubaté. Relatório 23.724, 2v., São Paulo.

Janasi, V.A. \& Ulbrich, H.H.G.J. 1991. Late Proterozoic granitoid magmatism in the state of São Paulo, southern Brazil. Precambrian Research, 51:351-354. 
Juliani, C. 1993. Geologia, petrogênese e aspectos metalogenéticos dos grupos Serra de Itaberaba e São Roque na região das Serras do Itaberaba e da Pedra Branca, NE da cidade de São Paulo, SP. São Paulo, 803p. (Tese de doutoramento, Instituto de Geociências, Universidade de São Paulo).

Karickhoff, S.W.; Brown, D.S.; Scott, T.A. 1979. Sorption of hydrophobic pollutants on natural sediments. Water Res., 13:241-248.

Lauar, C.R.M. 1988. Paleomagnetismo e correlações com idades radiométricas: alguns exemplos. São Paulo, 29p. (Seminário, Instituto de Geociências, Universidade de São Paulo).

Leite, S.Q.M.; Dieguez, L.C.; Gil, R.A.S.S.; Menezes, S.M.C. 2000. Pilarização de esmectita brasileira para fins catalíticos. Emprego de argila pilarizada na alquilação de benzeno com 1-dodeceno. Química Nova, 23: 149-154.

Li, Y. \& Gupta, G. 1994. Adsorption of hydrocarbons by clay minerals from gasoline. Journal of Hazardous Materials, 38:105-112.

Lima, M.R. \& Amador, E.S. 1985. Análise palinológica de sedimentos da Formação Resende, Terciário do Estado do Rio de Janeiro, Brasil. In: Coletânea de trabalhos paleontológicos, Brasília, DNPM. Série Geologia, 27, Seção Paleontologia $e$ Estratigrafia, 2, p.371-378.

Lima, M.R. \& Melo, M.S. 1989. Palinologia de sedimentos da Bacia de São Paulo. In: Workshop Geologia da Bacia de São Paulo, São Paulo. SBG/IGc-USP, São Paulo, p. 35-37.

Lo, I.M.C. \& Yang, X. 2001. Laboratory investigation of the migration of hydrocarbons in organobentonite. Environmental Science \&Technology, 35: 620-625.

Machado Filho, L.; Ribeiro, M.; Gonzalez, S.R.; Schenini, C.A.; Santos Neto, A.; Palmeira, R. C.; Pires, J.L.; Teixeira, W.; Castro, H.E.F. 1983. Geologia. In: Ministério das Minas e Energia. Projeto Radambrasil, Levantamento de Recursos Minerais, Folhas SF. 23/24 Rio de Janeiro/Vitória. Vol.32, p.27-304.

Melo, M.S.; Caetano, S.L.V.; Coimbra, A.M. 1986. Tectônica e sedimentação na área das bacias de São Paulo e Taubaté. In: Congresso Brasileiro de Geologia, 34, Goiânia. SBG, Goiânia, v.1, p. 321-336.

METRÔ - Companhia do Metropolitano de São Paulo. 2009. Informações sobre o traçado da expansão da Linha 2-Verde. Website (http://www.metro.sp.gov.br/expansao/verde/tracado.shtml).

Millot, G. 1970. Geology of Clays. Chapman \& Hall, Londres, 429p.

Moore, D.M. \& Reynolds, R.C. 1997. X-ray diffraction and the identification ad analysis of clay minerals. Oxford University Press, Oxford, 377p.

Neumann, M. G.; Gessner, F.; Cione, A.P.P.; Sartori, R.A.; Schmitt Cavalheiro, C.C. 2000. Interações entre corantes e argilas em suspensão aquosa. Química Nova, 23: 818-824.

Oliveira, E.C. \& Pereira, M.A.C. 2006. Efeito da mistura E24 comparado à gasolina pura na espessura da fase livre de poços de monitoramento. Rev. Águas Subterrâneas, 20: 1-8.

Parker, A. \& Rae, J.E. 1998. Environmental Interaction of Clays. Clays and the Environment. Springer-Verlag, Berlin, 271p.

Pereira, K.R.O.; Hanna, R.A.; Vianna, M.M.G.R.; Pinto, C.A.; Rodrigues, M.G.F.; Valenzuela-Diaz, F.R. 2005. Brazilian organoclays as nanostructured sorbents of petroleum-derived hydrocarbons. Materials Research, 8: 77-80. 
Pereira, S.M. 2003. Relação entre a espessura real e aparente da gasolina com etanol e da gasolina pura em colunas de laboratório. São Paulo, 107p. (Tese de Doutoramento, Instituto de Geociências, Universidade de São Paulo).

Perlinger, J.A. \& Eisenreich, S.J. 1991. Sorption of alkylbenzene to mineral oxides. In: Baker, R.A. (ed). Organic substances and sediments in water. Lewis Publishers, Chelsea, p.4978.

Piwoni, M.D. \& Banerjee, P. 1989. Sorption of volatile organic solvents from aqueous solution onto subsurface solids. J. Contam. Hydrol., 4:162-179.

Riccomini, C. \& Coimbra, A.M. 1992. Geologia da bacia sedimentar. In: Negro Jr., A.; Ferreira, A.A.; Alonso, U.R.; Luz, P.A. (eds). Solos da Cidade de São Paulo. ABMS/ABEF, São Paulo, p.37-94.

Riccomini, C. 1989. O Rift Continental do Sudeste do Brasil. São Paulo, 256p. (Tese de Doutoramento, Instituto de Geociências, Universidade de São Paulo).

Riccomini, C.; Appi, C.J.; Freitas, E.L.; Arai, M. 1987. Tectônica e sedimentação no Sistema de Rifts Continentais da Serra do Mar (bacias de Volta Redonda, Resende, Taubaté e São Paulo). In: Simpósio Regional de Geologia, 1, Rio de Janeiro. SBG, Rio de Janeiro, p. 253-298.

Riccomini, C.; Coimbra, A.M.; Brandt Neto, M.; Sant'Anna, L.G. 1994. Geologia e aspectos tecnológicos das argilas esmectíticas do Estado de São Paulo. In: WORKSHOP RECURSOS MINERAIS NÃO-METÁLICOS PARA O ESTADO DE SÃO PAULO, São Paulo. Resumos Expandidos. São Paulo, SBG/NSP, p.43-50.

Riccomini, C.; Melo, M.S.; Almeida, F.F.M.; Mioto, J.A.; Hasui, Y. 1983. Sobre a ocorrência de um derrame de ankaramito na Bacia de Volta Redonda (RJ) e sua importância na datação das bacias tafrogências continentais do sudeste do brasileiro. In: Simpósio Regional de Geologia, 4, São Paulo. Resumos. São Paulo, Sociedade Brasileira de Geologia, p.23-24.

Riccomini, C.; Sant'Anna, L.G.; Ferrari, A. 2004. Evolução geológica do Rift Continental do Sudeste do Brasil. In: Matesso-Neto, V.; Bartorelli, A.; Carneiro, C.D.R.; Brito-Neves, B.B. (eds). Geologia do Continente Sul-Americano: Evolução da obra de Fernando Flávio Marques de Almeida. BECA, São Paulo, p.383-405.

Robertson, R.H.S. 1986. Fuller's Earth. A History of Calcium Montmorillonite. Volturna Press, Hythe Kent.

Ruiz-Hitzky, E. \& Van Meerbeek, A. 2006. Clay Mineral- and Organoclay-Polymer Nanocomposite. In: Bergaya, F.; Theng, B.K.G.; Lagaly, G. (eds). Handbook of Clay Science. Elsevier, Amsterdam. Developments in Clay Science, Vol. 1, p. 583-623.

Russel Boulding, J. \& Ginn, J.S. 2004. Soil, vadose zone, and ground-water contamination: assessment, prevention and remediation. Lewis, Florida, 691p.

Sadowski, G. R. \& Motidome, M. 1987. Brazilian megafaults. Revista Geologica del Chile, v. 31, n. Especial, p. 61-75.

Sanchez, L. E. 2001. Desengenharia - O Passivo Ambiental na desativação de empreendimentos industriais. EDUSP, São Paulo, 256p.

Sant'Anna, L. G. \& Riccomini, C. 2001. Cimentação hidrotermal em depósitos paleogênicos do Rift Continental do Sudeste do Brasil: mineralogia e relações tectônicas. Revista Brasileira de Geociências, 31:231-240. 
Sant'Anna, L.G. 1999. Geologia, mineralogia e gênese das esmectitas dos depósitos sedimentares paleogênicos do Rift Continental do Sudeste do Brasil. São Paulo, 256p.(Tese de doutoramento, Instituto de Geociências da Universidade de São Paulo).

Sant'Anna, L.G.; Riccomini, C.; Dantas, E.; Fetter, A.H.; Roig, H.L.; Hackspacher, P.C. 2003. Provenance of detrital clay minerals of the Continental Rift of Southeastern Brazil: mineralogical and Sm-Nd data. In: South American Symposium on Isotope Geology, 4, Salvador. Short Papers, p.271-273.

Santos, P.S. 1963. Análise térmica diferencial de argilas descorantes. Bol. Tec. Petrobras, 6:117174.

Santos, P.S. 1989. Ciência e tecnologia de argilas. Edgard Blücher, São Paulo, vol 1., 408p.

Sharmasarkar, S.; Jaynes, W.F.; Vance, G.F. 2000. BTEX sorption by montmorilloniteorganoclays: TMPA, ADAM, HDTMA. Water, Air, and Soil Pollution, 119: 257-273.

Smith, J.A.; Bartelt-Hunt, S.A.; Burns, S.E. 2003. Sorption and permeability of gasoline hydrocarbons in organobentonite porous media. Journal of Harzadous Materials, B96: 91-97.

Sonoki I.K. \& Garda G.M. 1988. Idades K-Ar de rochas alcalinas do Brasil meridional e Paraguai oriental: compilação e adaptação às novas constantes de decaimento. Boletim IGUSP, Série Científica, 19:63-85.

Suguio, K. 1969. Contribuição à geologia da Bacia de Taubaté, Vale do Paraíba - Estado de São Paulo. São Paulo 106p. (Tese de doutoramento, Instituto de Geociências, Universidade de São Paulo).

Takyia, H. 1991. Aplicação de métodos quantitativos espaciais a dados geológicos da Bacia de São Paulo. São Paulo, 109p. (Dissertação de mestrado, Instituto de Geociências, Universidade de São Paulo).

Trovão, R.S. 2006. Análise ambiental de solos e águas subterrâneas contaminadas com gasolina: estudo de caso no Município de Guarulhos-SP. São Paulo, 157p. (Dissertação de Mestrado, Departamento de Minas e Petróleo, Escola Politécnica, Universidade de São Paulo).

Turcq, B. \& Melo, M.S. 1989. O Quaternário na área da Grande São Paulo. In: Workshop Geologia da Bacia de São Paulo, São Paulo. SBG/IGc-USP, São Paulo, p. 64-70.

Valenzuela Diaz, F.R. 1994. Preparação, em nível de laboratório, de algumas argilas esmectíticas organofílicas. São Paulo, 256p. (Tese de Doutoramento, Escola Politécnica, Universidade de São Paulo).

Velde, B. 1992. Introduction to clay minerals - Chemistry, origins, uses, and environmental significance. Chapman \& Hall, London, 198p.

Velde, B. 1995. Origin and mineralogy of clays. Springer-Verlag, Berlin, 334p.

Vianna, M.M.G.R. 2004. Sorption of oil pollution by organoclays and a coal/mineral complex. Brazilian Journal of Chemical Engineering, 21: 239-245.

Vianna, M.M.G.R. 2005. Desenvolvimento de argilas organofilicas visando à remediação de áreas contaminadas por componentes da gasolina. São Paulo, 133p. (Tese de Doutoramento, Escola Politécnica, Universidade de São Paulo).

Weaver, C.E. 1989. Clays, muds and shales. Elsevier, Amsterdam, 819p.

Wentworth, C.K. 1922. A scale of grade and class terms for clastic sediments. J. Geol., 30:377392. 
Yamamoto, I.T. 1995. Palinologia das bacias tafrogênicas do sudeste (bacias de Taubaté, São Paulo e Resende): análise bioestratigráfica integrada e interpretação paleoambiental. Rio Claro, 217p. (Dissertação de mestrado, Instituto de Geociências e Ciências Exatas, Universidade Estadual Paulista).

Yang, X.; Beckmann, D.; Fiorenza, S.; Niedermeier, C. 2005. Field study of pulsed air sparging for remediation of petroleum hydrocarbon contaminanted soil and groundwater. Environ. Sci. Technol., 39:7279-7286.

Zandonadi, A.R. 1972. Estudo tecnológico de argilas nontronítricas brasileiras. São Paulo, 137p. (Tese de doutoramento, Instituto de Química, Universidade de São Paulo). 
Anexo 
Observações sobre as tabelas:

Todos os valores de concentrações de contaminantes estão em mg/kg;

ND- Não detectado;

Campos em branco - resultados não entregues pelo laboratório

Para os ensaios de sorção e desorção, as amostras foram codificadas, de acordo com suas informações de origem, tipo de ensaio e contaminante empregado. A codificação gerou denominações do tipo XXYZWKKK, onde:

[XX] - refere-se ao local de coleta da amostra: BP - Bom Pastor,JP - Juntas Provisórias, CA - Cavour;

$[\mathrm{Y}]$ - nome do contaminante utilizado: $\mathrm{G}$ - gasolina, $\mathrm{B}$ - benzeno, $\mathrm{T}$ - tolueno, $\mathrm{X}$ - xileno;

[Z] - fração granulométrica analisada: T- rocha total, S - silte, A - argila;

[W] - tipo de ensaio realizado: S - sorção, D - desorção;

[KKK] - tempo de ensaio (ex.: $24 \mathrm{H}=24$ horas, $16 \mathrm{D}=16$ dias).

Para envio ao laboratório, foi criada ainda uma numeração seqüencial, visando evitar a identificação pelo laboratório do tipo de contaminante utilizado ou da amostra, procurando assim manter a qualidade dos resultados obtidos.

Tabela 13 - Concentrações de BTEX (em mg/Kg) obtidas no ensaio de sorção de gasolina pelo argilito coletado na Rua Bom Pastor (amostra BP), na forma de rocha total (T), fração silte (S) e fração argila (A).

\begin{tabular}{ccccccc}
\hline Código & Sequencial & Benzeno & Tolueno & Etilbenzeno & Mp-Xilenos & o-xileno \\
\hline BPGTS30M & 218 & $6.226,52$ & $12.843,96$ & $5.217,55$ & $26.922,24$ & $9.193,95$ \\
BPGTS2H & 219 & $4.945,80$ & $11.155,89$ & $4.586,88$ & $23.344,02$ & $8.131,46$ \\
BPGTS6H & 220 & 582,14 & $2.890,91$ & $1.028,00$ & $6.125,59$ & $2.523,62$ \\
BPGTS18H & 221 & 708,88 & $2.589,11$ & 813,10 & $5.794,36$ & $1.715,97$ \\
BPGTS24H & 222 & $1.745,82$ & $9.280,05$ & $3.110,61$ & $13.799,92$ & $6.272,54$ \\
BPGTS4D & 223 & $4.142,19$ & $8.630,89$ & $2.567,05$ & $14.660,23$ & $4.946,71$ \\
BPGTS16D & 224 & 573,23 & $3.316,19$ & $1.267,73$ & $5.596,92$ & $2.286,80$ \\
BPGTS32D & 225 & $1.527,04$ & $5.692,21$ & $1.299,31$ & $7.733,73$ & $2.949,85$ \\
\hline BPGSS30M & 236 & $2.549,31$ & $4.084,99$ & $1.669,40$ & $9.849,10$ & $3.040,73$ \\
BPGSS2H & 237 & $4.832,20$ & $9.860,60$ & $3.790,36$ & $18.974,43$ & $7.198,64$ \\
BPGSS6H & 238 & 292,38 & $2.460,84$ & $1.084,10$ & $6.171,73$ & $2.393,34$ \\
BPGSS18H & 239 & $1.772,99$ & $6.093,54$ & $1.837,99$ & $14.461,50$ & $4.136,42$ \\
BPGSS24H & 240 & $1.097,96$ & $6.920,96$ & $2.409,02$ & $10.718,10$ & $4.052,95$ \\
BPGSS4D & 241 & $4.729,64$ & $9.586,92$ & $3.469,58$ & $17.588,90$ & $6.109,37$ \\
BPGSS16D & 242 & 186,61 & $1.650,88$ & 695,07 & $3.537,56$ & $1.479,56$ \\
BPGSS32D & 243 & $11.046,55$ & $9.931,40$ & $3.565,51$ & $23.763,66$ & $6.643,50$ \\
BPGAS30M & 254 & & & & & \\
\hline BPGAS2H & 255 & $4.800,53$ & $9.842,89$ & $3.809,43$ & $18.442,22$ & $6.532,00$ \\
BPGAS6H & 256 & 719,08 & $3.352,94$ & $1.019,04$ & $7.984,27$ & $2.177,87$ \\
BPGAS18H & 257 & $1.223,84$ & $5.527,55$ & $1.668,53$ & $12.109,06$ & $3.503,94$ \\
BPGAS24H & 258 & $1.838,36$ & $9.860,74$ & $3.367,93$ & $16.667,83$ & $6.785,23$ \\
BPGAS4D & 259 & $4.221,22$ & $11.138,19$ & $4.307,92$ & $27.540,91$ & $8.281,75$ \\
BPGAS16D & 260 & $4.711,69$ & $9.948,55$ & $3.650,88$ & $20.464,72$ & $6.294,92$ \\
BPGAS32D & 261 & $6.878,28$ & $8.630,83$ & $3.079,85$ & $19.105,68$ & $5.782,18$ \\
\hline
\end{tabular}


Tabela 14 - Concentrações de benzeno (em $\mathrm{mg} / \mathrm{Kg}$ ) obtidas no ensaio de sorção do contaminante puro pelo argilito coletado na Rua Bom Pastor (amostra BP), na forma de rocha total (T), fração silte (S) e fração argila (A).

\begin{tabular}{ccccccc}
\hline Código & Sequencial & Benzeno & Tolueno & Etilbenzeno & Mp-Xilenos & o-xileno \\
\hline BPBTS30M & 272 & $248.038,37$ & ND & ND & ND & ND \\
BPBTS2H & 273 & & & & & \\
BPBTS6H & 274 & $433.000,35$ & ND & ND & ND & ND \\
BPBTS18H & 275 & 851,31 & 244,03 & ND & 153,83 & ND \\
BPBTS24H & 276 & $229.867,52$ & ND & ND & ND & ND \\
BPBTS4D & 277 & $814.154,69$ & ND & ND & ND & ND \\
BPBTS16D & 278 & $189.021,63$ & ND & ND & ND & ND \\
BPBTS32D & 279 & $614.771,65$ & ND & ND & ND & ND \\
\hline BPBSS30M & 290 & $352.378,98$ & ND & ND & ND & ND \\
BPBSS2H & 291 & $41.473,50$ & ND & ND & ND & ND \\
BPBSS6H & 292 & $116.743,07$ & ND & ND & ND & ND \\
BPBSS18H & 293 & ND & 421,94 & ND & 408,72 & ND \\
BPBSS24H & 294 & & & & & \\
BPBSS4D & 295 & $568.653,50$ & ND & ND & ND & ND \\
BPBSS16D & 296 & ND & 15,33 & ND & 116,56 & ND \\
BPBSS32D & 297 & $283.916,00$ & ND & ND & ND & ND \\
\hline BPBAS30M & 308 & $64.778,61$ & ND & ND & ND & ND \\
BPBAS2H & 309 & $187.121,18$ & ND & ND & ND & ND \\
BPBAS6H & 310 & $238.673,25$ & ND & ND & ND & ND \\
BPBAS18H & 311 & $1.349,32$ & 407,47 & ND & 261,51 & ND \\
BPBAS24H & 312 & $437.773,60$ & ND & ND & ND & ND \\
BPBAS4D & 313 & $591.190,72$ & ND & ND & ND & ND \\
BPBAS16D & 314 & $9.733,69$ & ND & ND & ND & ND \\
BPBAS32D & 315 & & & & & \\
\hline
\end{tabular}

Tabela 15 - Concentrações de tolueno (em $\mathrm{mg} / \mathrm{Kg}$ ) obtidas no ensaio de sorção do contaminante puro pelo argilito coletado na Rua Bom Pastor (amostra BP), na forma de rocha total (T), fração silte (S) e fração argila (A).

\begin{tabular}{ccccccc}
\hline Código & Sequencial & Benzeno & Tolueno & Etilbenzeno & Mp-Xilenos & o-xileno \\
\hline BPTTS30M & 326 & ND & $3.766,85$ & ND & 465,93 & ND \\
BPTTS2H & 327 & ND & $577.970,82$ & ND & ND & ND \\
BPTTS6H & 328 & ND & 443,76 & ND & 360,70 & ND \\
BPTTS18H & 329 & ND & $616.628,10$ & ND & ND & ND \\
BPTTS24H & 330 & ND & $390.285,25$ & ND & ND & ND \\
BPTTS4D & 331 & ND & $219.080,38$ & ND & ND & ND \\
BPTTS16D & 332 & ND & $95.955,86$ & ND & ND & ND \\
BPTTS32D & 333 & ND & $672.735,94$ & ND & ND & ND \\
\hline BPTSS30M & 344 & ND & ND & ND & $1.137,77$ & ND \\
BPTSS2H & 345 & ND & $486.437,50$ & ND & ND & ND \\
BPTSS6H & 346 & ND & ND & ND & 177,69 & ND \\
BPTSS18H & 347 & ND & $272.541,63$ & ND & ND & ND \\
BPTSS24H & 348 & ND & $333.754,75$ & ND & ND & ND \\
BPTSS4D & 349 & ND & $141.448,93$ & ND & ND & ND \\
BPTSS16D & 350 & ND & 5,66 & ND & 39,15 & ND \\
BPTSS32D & 351 & ND & $226.377,42$ & ND & ND & ND \\
\hline BPTAS30M & 362 & ND & $62.324,91$ & ND & ND & ND \\
BPTAS2H & 363 & ND & $426.707,62$ & ND & ND & ND \\
BPTAS6H & 364 & & & & & \\
BPTAS18H & 365 & ND & $344.668,96$ & ND & ND & ND \\
BPTAS24H & 366 & ND & $313.954,75$ & ND & ND & ND
\end{tabular}




\begin{tabular}{ccccccc} 
BPTAS4D & 367 & ND & $69.302,74$ & ND & ND & ND \\
BPTAS16D & 368 & ND & $19.885,88$ & ND & ND & ND \\
BPTAS32D & 369 & & & & & \\
\hline
\end{tabular}

Tabela 16 - Concentrações de xilenos (em $\mathrm{mg} / \mathrm{Kg}$ ) obtidas no ensaio de sorção do contaminante puro pelo argilito coletado na Rua Bom Pastor (amostra BP), na forma de rocha total (T), fração silte (S) e fração argila (A).

\begin{tabular}{ccccccc}
\hline Código & Sequencial & Benzeno & Tolueno & Etilbenzeno & Mp-Xilenos & o-xileno \\
\hline PXTS30M & 380 & ND & ND & $8.163,01$ & $342.662,08$ & $6.811,90$ \\
BPXTS2H & 381 & ND & ND & ND & $575.845,38$ & ND \\
BPXTS6H & 382 & ND & ND & ND & $32.970,85$ & ND \\
BPXTS18H & 383 & ND & ND & ND & $139.442,22$ & ND \\
BPXTS24H & 384 & ND & ND & ND & $502.932,10$ & ND \\
BPXTS4D & 385 & ND & ND & ND & $358.336,51$ & ND \\
BPXTS16D & 386 & ND & ND & ND & $30.191,33$ & ND \\
BPXTS32D & 387 & ND & ND & ND & $1.228 .709,38$ & ND \\
\hline BPXSS30M & 398 & ND & ND & ND & $336.045,15$ & ND \\
BPXSS2H & 399 & ND & ND & ND & $509.250,66$ & ND \\
BPXSS6H & 400 & ND & ND & ND & $14.335,96$ & ND \\
BPXSS18H & 401 & ND & ND & ND & $845.379,01$ & ND \\
BPXSS24H & 402 & ND & ND & ND & $609.311,55$ & ND \\
BPXSS4D & 403 & ND & ND & ND & $467.453,18$ & ND \\
BPXSS16D & 404 & ND & ND & ND & $29.177,61$ & ND \\
BPXSS32D & 405 & ND & ND & ND & $412.038,14$ & ND \\
\hline BPXAS30M & 416 & ND & ND & ND & $634.454,66$ & ND \\
BPXAS2H & 417 & & & & & \\
BPXAS6H & 418 & ND & ND & ND & $47.784,66$ & ND \\
BPXAS18H & 419 & ND & ND & ND & $428.880,67$ & ND \\
BPXAS24H & 420 & ND & ND & ND & $36.782,05$ & ND \\
BPXAS4D & 421 & ND & ND & ND & $912.280,90$ & ND \\
BPXAS16D & 422 & ND & ND & ND & $17.550,19$ & ND \\
BPXAS32D & 423 & & & & & \\
\hline
\end{tabular}

Tabela 17 - Concentrações de BTEX (em mg/Kg) obtidas no ensaio de sorção de gasolina pelo argilito coletado na Av. Juntas Provisórias (amostra JP), na forma de rocha total (T), fração silte (S) e fração argila (A).

\begin{tabular}{ccccccc}
\hline Código & Sequencial & Benzeno & Tolueno & Etilbenzeno & Mp-Xilenos & o-xileno \\
\hline JPGTS30M & 2 & & & & & \\
JPGTS2H & 3 & $4.794,16$ & $9.073,52$ & $3.414,95$ & $16.744,34$ & $5.948,66$ \\
JPGTS6H & 4 & $1.009,17$ & $2.947,92$ & 847,48 & $5.702,57$ & $1.740,57$ \\
JPGTS18H & 5 & 600,63 & $2.395,21$ & 769,58 & $5.811,97$ & $1.688,56$ \\
JPGTS24H & 6 & & & & & \\
JPGTS4D & 7 & $2.886,72$ & $11.423,74$ & $4.309,79$ & $23.177,47$ & $6.229,05$ \\
JPGTS16D & 8 & $4.372,18$ & $7.918,20$ & $2.715,91$ & $14.892,78$ & $6.437,49$ \\
JPGTS32D & 9 & 771,98 & $7.816,12$ & $3.287,70$ & $13.650,20$ & $6.822,25$ \\
\hline JPGSS30M & 20 & $4.068,96$ & $9.416,40$ & $3.847,50$ & $21.490,21$ & $6.666,47$ \\
JPGSS2H & 21 & $5.538,24$ & $11.323,50$ & $4.398,73$ & $21.785,43$ & $7.488,86$ \\
JPGSS6H & 22 & 954,56 & $2.138,29$ & 895,03 & $6.938,87$ & $2.030,10$ \\
JPGSS18H & 23 & 932,29 & $4.290,55$ & $1.319,04$ & $10.346,63$ & $2.954,58$ \\
JPGSS24H & 24 & $1.470,05$ & $10.372,25$ & $3.972,45$ & $16.455,32$ & $7.759,94$ \\
JPGSS4D & 25 & $3.413,53$ & $7.362,09$ & $2.557,92$ & $13.778,34$ & $4.467,26$ \\
JPGSS16D & 26 & 137,04 & $1.456,44$ & 671,83 & $2.975,56$ & $1.235,45$ \\
JPGSS32D & 27 & 730,59 & 864,31 & 311,12 & $2.205,54$ & 588,49 \\
\hline JPGAS30M & 38 & $4.442,65$ & $10.097,08$ & $3.939,68$ & $21.924,38$ & $7.051,20$
\end{tabular}




\begin{tabular}{ccccccc} 
JPGAS2H & 39 & $5.543,30$ & $9.407,74$ & $3.282,44$ & $16.193,55$ & $5.584,84$ \\
JPGAS6H & 40 & $1.159,64$ & $3.349,03$ & $1.074,68$ & $7.691,82$ & $2.320,13$ \\
JPGAS18H & 41 & 674,05 & $2.832,37$ & 902,46 & $5.482,68$ & $1.941,08$ \\
JPGAS24H & 42 & $1.308,28$ & $11.094,86$ & $4.272,31$ & $17.334,96$ & $8.572,65$ \\
JPGAS4D & 43 & $4.739,48$ & $8.754,94$ & $2.804,88$ & $14.188,06$ & $4.790,03$ \\
JPGAS16D & 44 & $3.269,13$ & $7.484,04$ & $2.068,86$ & $11.488,53$ & $4.246,02$ \\
JPGAS32D & 45 & $8.980,64$ & $9.349,53$ & $3.183,25$ & $19.968,93$ & $5.947,15$ \\
\hline
\end{tabular}

Tabela 18 - Concentrações de benzeno (em $\mathrm{mg} / \mathrm{Kg}$ ) obtidas no ensaio de sorção do contaminante puro pelo argilito coletado na Av. Juntas Provisórias (amostra JP), na forma de rocha total (T), fração silte (S) e fração argila (A).

\begin{tabular}{ccccccc}
\hline Código & Sequencial & Benzeno & Tolueno & Etilbenzeno & Mp-Xilenos & o-xileno \\
\hline JPBTS30M & 56 & $259.405,36$ & ND & ND & ND & ND \\
JPBTS2H & 57 & & & & & \\
JPBTS6H & 58 & $240.741,79$ & ND & ND & ND & ND \\
JPBTS18H & 59 & 257,01 & 310,97 & ND & 199,50 & ND \\
JPBTS24H & 60 & & & & & \\
JPBTS4D & 61 & $491.049,41$ & ND & ND & ND & ND \\
JPBTS16D & 62 & $480.115,26$ & ND & ND & ND & ND \\
JPBTS32D & 63 & $314.143,71$ & ND & ND & ND & ND \\
\hline JPBSS30M & 74 & ND & ND & $3.472,87$ & $144.858,02$ & $2.750,37$ \\
JPBSS2H & 75 & $321.150,24$ & ND & ND & ND & ND \\
JPBSS6H & 76 & $268.195,62$ & ND & ND & ND & ND \\
JPBSS18H & 77 & ND & 519,01 & ND & 350,10 & ND \\
JPBSS24H & 78 & & & & & \\
JPBSS4D & 79 & $622.559,30$ & ND & ND & ND & ND \\
JPBSS16D & 80 & $78.380,78$ & ND & ND & ND & ND \\
JPBSS32D & 81 & $331.452,42$ & ND & ND & ND & ND \\
\hline JPBAS30M & 92 & $216.900,46$ & ND & ND & ND & ND \\
JPBAS2H & 93 & & & & & ND \\
JPBAS6H & 94 & $320.467,23$ & ND & ND & ND \\
JPBAS18H & 95 & $90.814,61$ & ND & ND & ND & ND \\
JPBAS24H & 96 & & & & ND & ND \\
JPBAS4D & 97 & $624.140,10$ & ND & ND & ND \\
JPBAS16D & 98 & $9.535,59$ & ND & ND & ND & ND \\
JPBAS32D & 99 & $593.619,58$ & ND & ND & & \\
\hline
\end{tabular}

Tabela 19 - Concentrações de tolueno (em $\mathrm{mg} / \mathrm{Kg}$ ) obtidas no ensaio de sorção do contaminante puro pelo argilito coletado na Av. Juntas Provisórias (amostra JP), na forma de rocha total (T), fração silte (S) e fração argila (A).

\begin{tabular}{ccccccc}
\hline Código & Sequencial & Benzeno & Tolueno & Etilbenzeno & Mp-Xilenos & o-xileno \\
\hline JPTTS30M & 110 & ND & $398.108,32$ & ND & ND & ND \\
JPTTS2H & 111 & ND & $2.338,78$ & ND & 275,83 & ND \\
JPTTS6H & 112 & ND & $204.827,17$ & ND & ND & ND \\
JPTTS18H & 113 & ND & $69.511,89$ & ND & 496,84 & ND \\
JPTTS24H & 114 & $3.187,40$ & $123.832,70$ & ND & $3.380,30$ & ND \\
JPTTS4D & 115 & ND & $306.987,58$ & ND & ND & ND \\
JPTTS16D & 116 & ND & $3.527,18$ & ND & ND & ND \\
JPTTS32D & 117 & ND & $255.074,62$ & ND & ND & ND \\
\hline JPTSS30M & 128 & ND & $730.578,24$ & ND & ND & ND \\
JPTSS2H & 129 & & & & & \\
JPTSS6H & 130 & ND & $148.985,79$ & ND & ND & ND
\end{tabular}




\begin{tabular}{ccccccc} 
JPTSS18H & 131 & ND & $56.271,10$ & ND & 330,77 & ND \\
JPTSS24H & 132 & ND & $167.652,38$ & ND & ND & ND \\
JPTSS4D & 133 & ND & $401.093,06$ & ND & ND & ND \\
JPTSS16D & 134 & ND & $19.286,81$ & ND & ND & ND \\
JPTSS32D & 135 & ND & $411.375,55$ & ND & ND & ND \\
\hline JPTAS30M & 146 & ND & $570.104,83$ & ND & ND & ND \\
JPTAS2H & 147 & ND & $44.063,12$ & ND & ND & ND \\
JPTAS6H & 148 & ND & $131.365,54$ & ND & ND & ND \\
JPTAS18H & 149 & ND & $75.070,65$ & ND & 266,51 & ND \\
JPTAS24H & 150 & ND & $342.034,30$ & ND & ND & ND \\
JPTAS4D & 151 & ND & $444.618,46$ & ND & ND & ND \\
JPTAS16D & 152 & ND & $68.118,78$ & ND & ND & ND \\
JPTAS32D & 153 & ND & $238.029,62$ & ND & ND & ND
\end{tabular}

Tabela 20 - Concentrações de xilenos (em $\mathrm{mg} / \mathrm{Kg}$ ) obtidas no ensaio de sorção do contaminante puro pelo argilito coletado na Av. Juntas Provisórias (amostra JP), na forma de rocha total (T), fração silte (S) e fração argila (A).

\begin{tabular}{ccccccc}
\hline Código & Sequencial & Benzeno & Tolueno & Etilbenzeno & Mp-Xilenos & O-Xilenos \\
\hline JPXTS30M & 164 & ND & ND & ND & $706.303,74$ & ND \\
JPXTS2H & 165 & ND & ND & $2.104,53$ & $85.522,17$ & $1.646,56$ \\
JPXTS6H & 166 & & & & & \\
JPXTS18H & 167 & ND & $6.725,60$ & 505,20 & $28.848,18$ & 567,07 \\
JPXTS24H & 168 & ND & ND & ND & $168.049,07$ & ND \\
JPXTS4D & 169 & & & & & \\
JPXTS16D & 170 & ND & ND & ND & $32.079,18$ & ND \\
JPXTS32D & 171 & ND & ND & ND & $342.785,18$ & ND \\
\hline JPXSS30M & 182 & & & & & \\
JPXSS2H & 183 & ND & ND & $8.181,17$ & $330.326,85$ & $6.568,44$ \\
JPXSS6H & 184 & & & & & \\
JPXSS18H & 185 & ND & ND & ND & $52.898,38$ & ND \\
JPXSS24H & 186 & $3.281,96$ & $1.324,09$ & ND & $40.087,89$ & ND \\
JPXSS4D & 187 & ND & ND & ND & $173.684,13$ & ND \\
JPXSS16D & 188 & & & & & \\
JPXSS32D & 189 & ND & ND & ND & $353.438,08$ & ND \\
\hline JPXAS30M & 200 & ND & ND & ND & $650.647,30$ & ND \\
JPXAS2H & 201 & ND & ND & $4.808,45$ & $201.968,72$ & $4.204,93$ \\
JPXAS6H & 202 & ND & ND & ND & $54.542,78$ & ND \\
JPXAS18H & 203 & ND & ND & ND & $111.011,31$ & ND \\
JPXAS24H & 204 & $9.069,34$ & $4.529,55$ & ND & $60.063,86$ & ND \\
JPXAS4D & 205 & ND & ND & ND & $602.447,68$ & ND \\
JPXAS16D & 206 & ND & ND & ND & $36.653,46$ & ND \\
JPXAS32D & 207 & ND & ND & ND & $1.169 .845,89$ & ND \\
\hline & & & & &
\end{tabular}

Tabela 21 - Concentrações de BTEX (em mg/Kg) obtidas no ensaio de sorção de gasolina pelo argilito coletado na Rua Cavour (amostra CA), na forma de rocha total (T), fração silte (S) e fração argila (A).

\begin{tabular}{ccccccc}
\hline Código & Sequencial & Benzeno & Tolueno & Etilbenzeno & Mp-Xilenos & o-xileno \\
\hline CAGTS30M & 434 & $4.561,98$ & $9.159,98$ & $3.624,67$ & $18.477,51$ & $6.494,81$ \\
CAGTS2H & 435 & $4.601,63$ & $7.455,91$ & $2.664,84$ & $14.223,80$ & $4.513,28$ \\
CAGTS6H & 436 & 248,06 & $1.490,87$ & 807,21 & $5.457,35$ & $1.833,77$ \\
CAGTS18H & 437 & ND & $1.696,23$ & 730,39 & $5.697,62$ & $1.660,43$ \\
CAGTS24H & 438 & 967,04 & $6.142,35$ & $2.425,49$ & $10.747,86$ & $4.353,27$ \\
CAGTS4D & 439 & $3.433,02$ & $7.470,84$ & $2.381,40$ & $12.762,27$ & $4.041,70$
\end{tabular}




\begin{tabular}{ccccccc} 
CAGTS16D & 440 & 478,84 & $3.591,10$ & $1.729,28$ & $7.498,39$ & $31,26,899$ \\
CAGTS32D & 441 & $3.530,62$ & $7.532,89$ & $1.694,82$ & $11.448,30$ & $3.845,93$ \\
\hline CAGSS30M & 452 & $3.582,87$ & $7.746,78$ & $3.211,52$ & $16.880,96$ & $5.564,90$ \\
CAGSS2H & 453 & $3.032,11$ & $6.593,14$ & $2.715,99$ & $13.997,09$ & $4.829,61$ \\
CAGSS6H & 454 & 231,94 & $2.633,04$ & $1.227,69$ & $8.598,21$ & $2.843,72$ \\
CAGSS18H & 455 & 283,54 & $1.590,97$ & 618,11 & $4.574,52$ & $1.388,95$ \\
CAGSS24H & 456 & 724,45 & $5.754,23$ & $2.659,56$ & $10.164,34$ & $5.056,05$ \\
CAGSS4D & 457 & $2.588,39$ & $6.647,57$ & $2.057,85$ & $11.299,46$ & $3.652,13$ \\
CAGSS16D & 458 & 306,75 & $2.880,14$ & $1.385,54$ & $5.442,83$ & $2.417,50$ \\
CAGSS32D & 459 & $1.776,60$ & $7.974,38$ & $2.461,95$ & $15.758,81$ & $4.351,46$ \\
\hline CAGAS30M & 470 & $7.610,23$ & $13.178,26$ & $5.045,49$ & $28.263,02$ & $9.019,75$ \\
CAGAS2H & 471 & $3.883,08$ & $9.790,67$ & $3.742,65$ & $18.685,47$ & $7.270,68$ \\
CAGAS6H & 472 & $5.542,13$ & $7.157,96$ & $2.172,22$ & $16.813,69$ & $4.807,49$ \\
CAGAS18H & 473 & 773,29 & $3.329,39$ & 978,15 & $7.508,76$ & $2.251,75$ \\
CAGAS24H & 474 & $1.098,89$ & $7.300,80$ & $2.822,68$ & $11.280,29$ & $5.659,25$ \\
CAGAS4D & 475 & & & & & \\
CAGAS16D & 476 & & & & & \\
CAGAS32D & 477 & $5.043,29$ & $11.147,15$ & $3.636,18$ & $21.357,06$ & $6.457,42$ \\
\hline
\end{tabular}

Tabela 22 - Concentrações de benzeno (em $\mathrm{mg} / \mathrm{Kg}$ ) obtidas no ensaio de sorção do contaminante puro pelo argilito coletado na Rua Cavour (amostra CA), na forma de rocha total (T), fração silte (S) e fração argila (A).

\begin{tabular}{|c|c|c|c|c|c|c|}
\hline Código & Sequencial & Benzeno & Tolueno & Etilbenzeno & Mp-Xilenos & o-xileno \\
\hline CABTS30M & 488 & $257.792,00$ & ND & ND & ND & ND \\
\hline CABTS2H & 489 & 355,41 & 971,37 & ND & 247,63 & ND \\
\hline CABTS6H & 490 & $298.799,78$ & ND & ND & ND & ND \\
\hline CABTS18H & 491 & & & & & \\
\hline CABTS24H & 492 & $65.191,19$ & ND & ND & ND & ND \\
\hline CABTS4D & 493 & $560.647,42$ & ND & ND & ND & ND \\
\hline CABTS16D & 494 & $12.524,78$ & ND & ND & ND & ND \\
\hline CABTS32D & 495 & $512.574,08$ & ND & ND & ND & ND \\
\hline CABSS30M & 506 & $30.555,56$ & ND & ND & ND & ND \\
\hline $\mathrm{CABSS} 2 \mathrm{H}$ & 507 & 172,17 & 519,70 & ND & 559,81 & ND \\
\hline CABSS6H & 508 & $244.765,60$ & ND & ND & ND & ND \\
\hline CABSS18H & 509 & & & & & \\
\hline CABSS24H & 510 & $822.222,75$ & ND & ND & $2.722,55$ & ND \\
\hline CABSS4D & 511 & $549.440,06$ & ND & ND & ND & ND \\
\hline CABSS16D & 512 & 4,10 & 14,40 & ND & 76,01 & ND \\
\hline CABSS32D & 513 & $230.563,66$ & ND & ND & ND & ND \\
\hline CABAS30M & 524 & $76.580,86$ & 559,91 & ND & 294,49 & 39,62 \\
\hline CABAS2H & 525 & $268.595,71$ & ND & ND & ND & ND \\
\hline CABAS6H & 526 & $332.313,73$ & ND & ND & ND & ND \\
\hline CABAS18H & 527 & & & & & \\
\hline CABAS24H & 528 & & & & & \\
\hline CABAS4D & 529 & $557.287,74$ & ND & ND & ND & ND \\
\hline CABAS16D & 530 & & & & & \\
\hline CABAS32D & 531 & $494.545,02$ & ND & ND & ND & ND \\
\hline
\end{tabular}

Tabela 23 - Concentrações de tolueno (em $\mathrm{mg} / \mathrm{Kg}$ ) obtidas no ensaio de sorção do contaminante puro pelo argilito coletado na Rua Cavour (amostra CA), na forma de rocha total (T), fração silte (S) e fração argila (A).

\begin{tabular}{ccccccc}
\hline Código & Sequencial & Benzeno & Tolueno & Etilbenzeno & Mp-Xilenos & o-xileno \\
\hline CATTS30M & 542 & ND & $208.230,59$ & ND & 507,36 & ND \\
CATTS2H & 543 & ND & $27.754,03$ & ND & ND & ND
\end{tabular}




\begin{tabular}{lcccccc} 
CATTS6H & 544 & ND & 48,87 & ND & 262,73 & ND \\
CATTS18H & 545 & & & & & \\
CATTS24H & 546 & & & & & \\
CATTS4D & 547 & ND & $36.735,45$ & ND & ND & ND \\
CATTS16D & 548 & ND & $6.404,98$ & ND & 258,35 & ND \\
CATTS32D & 549 & ND & $139.388,06$ & ND & ND & ND \\
\hline CATSS30M & 560 & ND & $26.965,63$ & ND & 402,48 & ND \\
CATSS2H & 561 & ND & ND & ND & 385,57 & ND \\
CATSS6H & 562 & ND & 55,75 & ND & 146,44 & ND \\
CATSS18H & 563 & & & & & \\
CATSS24H & 564 & ND & $298.626,18$ & ND & ND & ND \\
CATSS4D & 565 & ND & $276.617,60$ & ND & ND & ND \\
CATSS16D & 566 & ND & $2.098,91$ & ND & 906,41 & ND \\
CATSS32D & 567 & & & & & \\
\hline CATAS30M & 578 & ND & $45.671,68$ & ND & ND & ND \\
CATAS2H & 579 & ND & $28.628,63$ & ND & ND & ND \\
CATAS6H & 580 & ND & $43.762,69$ & ND & ND & ND \\
CATAS18H & 581 & & & & & \\
CATAS24H & 582 & ND & $43.444,70$ & ND & ND & ND \\
CATAS4D & 583 & ND & $46.606,52$ & ND & ND & ND \\
CATAS16D & 584 & & & & & \\
CATAS32D & 585 & ND & $601.728,77$ & ND & ND & ND \\
\hline
\end{tabular}

Tabela 24 -Concentrações de xilenos (em $\mathrm{mg} / \mathrm{Kg}$ ) obtidas no ensaio de sorção do contaminante puro pelo argilito coletado na Rua Cavour (amostra CA), na forma de rocha total (T), fração silte (S) e fração argila (A).

\begin{tabular}{ccccccc}
\hline Código & Sequencial & Benzeno & Tolueno & Etilbenzeno & Mp-Xilenos & o-xileno \\
\hline CAXTS30M & 596 & ND & ND & $1.454,53$ & $598.080,95$ & $1.155,04$ \\
CAXTS2H & 597 & ND & ND & $1.609,01$ & $66.106,47$ & $1.296,25$ \\
CAXTS6H & 598 & ND & ND & ND & ND & $20.443,72$ \\
CAXTS18H & 599 & & & & & \\
CAXTS24H & 600 & & & & & \\
CAXTS4D & 601 & ND & ND & ND & ND & $386.644,26$ \\
CAXTS16D & 602 & ND & ND & ND & $47.030,53$ & ND \\
CAXTS32D & 603 & ND & ND & ND & $28.459,14$ & ND \\
\hline CAXSS30M & 614 & ND & ND & ND & $180.623,02$ & ND \\
CAXSS2H & 615 & ND & ND & $5.046,67$ & $209.185,02$ & $4.040,61$ \\
CAXSS6H & 616 & ND & ND & ND & $42.597,74$ & ND \\
CAXSS18H & 617 & & & & & ND \\
CAXSS24H & 618 & ND & ND & ND & $156.082,56$ & ND \\
CAXSS4D & 619 & ND & ND & ND & $348.615,16$ & ND \\
CAXSS16D & 620 & ND & ND & ND & $24.445,36$ & \\
CAXSS32D & 621 & & & & & ND \\
\hline CAXAS30M & 632 & ND & ND & 411,05 & $19.665,96$ & 449,67 \\
CAXAS2H & 633 & ND & ND & $1.443,01$ & $62.257,94$ & $1.273,12$ \\
CAXAS6H & 634 & ND & ND & ND & $43.657,28$ & ND \\
CAXAS18H & 635 & & & & & \\
CAXAS24H & 636 & ND & ND & ND & $654.444,29$ & ND \\
CAXAS4D & 637 & & & & & \\
CAXAS16D & 638 & & & & & \\
CAXAS32D & 639 & ND & ND & ND & $202.957,22$ & N \\
\hline
\end{tabular}


Tabela 25 - Concentrações de BTEX (em mg/Kg) obtidas no ensaio de desorção de gasolina pelo argilito coletado na Rua Bom Pastor (amostra BP), na forma de rocha total (T), fração silte (S) e fração argila (A).

\begin{tabular}{|c|c|c|c|c|c|c|}
\hline Código & Sequencial & Benzeno & Tolueno & Etilbenzeno & Mp-Xilenos & o-xileno \\
\hline BPGTD30M & 226 & & & & & \\
\hline BPGTD2H & 227 & & & & & \\
\hline BPGTD6H & 228 & & & & & \\
\hline BPGTD18H & 230 & $1.495,75$ & $1.757,94$ & $1.231,55$ & $7.265,73$ & $3.714,43$ \\
\hline BPGTD24H & 231 & $3.270,08$ & $11.027,71$ & $4.602,23$ & $23.364,87$ & $8.214,36$ \\
\hline BPGTD4D & 232 & 597,50 & 146,69 & $2.689,59$ & $15.274,29$ & $5.346,09$ \\
\hline BPGTD16D & 233 & ND & ND & 442,10 & $3.072,98$ & $1.938,31$ \\
\hline BPGTD32D & 234 & 37,53 & 213,84 & ND & 193,79 & ND \\
\hline BPGSD30M & 244 & & & & & \\
\hline BPGSD2H & 245 & & & & & \\
\hline BPGSD6H & 246 & & & & & \\
\hline BPGSD18H & 248 & $1.502,67$ & $1.607,54$ & 785,17 & $4.543,69$ & $1.715,80$ \\
\hline BPGSD24H & 249 & $2.951,36$ & $10.516,82$ & $3.912,59$ & $21.047,33$ & $6.967,63$ \\
\hline BPGSD4D & 250 & 534,81 & $4.053,77$ & $3.116,14$ & $17.715,43$ & $6.128,93$ \\
\hline BPGSD16D & 251 & 5,52 & 20,00 & 40,68 & 655,74 & 424,90 \\
\hline BPGSD32D & 252 & 73,07 & 221,05 & ND & 364,21 & ND \\
\hline BPGAD30M & 262 & & & & & \\
\hline BPGAD2H & 263 & & & & & \\
\hline BPGAD6H & 264 & 305,60 & $3.788,73$ & $2.303,14$ & $9.598,12$ & $4.026,57$ \\
\hline BPGAD18H & 266 & $1.251,59$ & $2.442,84$ & $1.892,18$ & $9.933,39$ & $5.253,21$ \\
\hline BPGAD24H & 267 & $3.818,31$ & $12.707,68$ & $4.954,22$ & $24.712,62$ & $8.618,17$ \\
\hline BPGAD4D & 268 & 257,32 & $3.184,39$ & $2.547,30$ & $13.732,63$ & $5.177,06$ \\
\hline BPGAD16D & 269 & & & & & \\
\hline BPGAD32D & 270 & ND & ND & ND & 849,47 & ND \\
\hline
\end{tabular}

Tabela 26 - Concentrações de benzeno (em $\mathrm{mg} / \mathrm{Kg}$ ) obtidas no ensaio de desorção do contaminante puro pelo argilito coletado na Rua Bom Pastor (amostra BP), na forma de rocha total (T), fração silte (S) e fração argila (A).

\begin{tabular}{|c|c|c|c|c|c|c|}
\hline Código & Sequencial & Benzeno & Tolueno & Etilbenzeno & Mp-Xilenos & o-xileno \\
\hline BPBTD30M & 280 & & & & & \\
\hline BPBTD2H & 281 & $3.187,74$ & 399,15 & ND & 282,22 & ND \\
\hline BPBTD6H & 282 & & & & & \\
\hline BPBTD18H & 284 & $74.964,22$ & ND & ND & ND & ND \\
\hline BPBTD24H & 285 & 553,42 & 102,40 & ND & 382,45 & ND \\
\hline BPBTD4D & 286 & 54,83 & 192,50 & ND & 181,67 & ND \\
\hline BPBTD16D & 287 & 8,51 & 37,99 & ND & 110,59 & ND \\
\hline BPBTD32D & 288 & 39,92 & 170,73 & ND & 170,67 & ND \\
\hline BPBSD30M & 298 & & & & & \\
\hline BPBSD2H & 299 & $1.331,33$ & ND & ND & ND & ND \\
\hline BPBSD6H & 300 & ND & 124,28 & ND & 91,10 & ND \\
\hline BPBSD18H & 302 & $58.835,66$ & ND & ND & ND & ND \\
\hline BPBSD24H & 303 & 832,17 & 153,10 & ND & 641,29 & ND \\
\hline BPBSD4D & 304 & 35,47 & 159,70 & ND & 147,41 & ND \\
\hline BPBSD16D & 305 & 4,30 & 20,88 & ND & 42,50 & ND \\
\hline BPBSD32D & 306 & 30,26 & 110,20 & ND & 121,33 & ND \\
\hline BPBAD30M & 316 & & & & & \\
\hline BPBAD2H & 317 & $40.411,28$ & ND & ND & ND & ND \\
\hline BPBAD6H & 318 & & & & & \\
\hline BPBAD18H & 320 & & & & & \\
\hline BPBAD24H & 321 & & & & & \\
\hline
\end{tabular}




\begin{tabular}{ccccccc} 
BPBAD4D & 322 & 616,81 & 96,60 & ND & 76,00 & ND \\
BPBAD16D & 323 & & & & & \\
BPBAD32D & 324 & 45,52 & 470,01 & ND & 550,34 & ND \\
\hline
\end{tabular}

Tabela 27 - Concentrações de tolueno (em $\mathrm{mg} / \mathrm{Kg}$ ) obtidas no ensaio de desorção do contaminante puro pelo o argilito coletado na Rua Bom Pastor (amostra BP), na forma de rocha total (T), fração silte (S) e fração argila (A).

\begin{tabular}{ccccccc}
\hline Código & Sequencial & Benzeno & Tolueno & Etilbenzeno & Mp-Xilenos & o-xileno \\
\hline BPTTD30M & 334 & & & & & \\
BPTTD2H & 335 & ND & $317.970,40$ & ND & ND & ND \\
BPTTD6H & 336 & ND & $365.873,86$ & ND & ND & ND \\
BPTTD18H & 338 & ND & $1.175,57$ & ND & ND & ND \\
BPTTD24H & 339 & 487,03 & 262,37 & ND & 268,09 & ND \\
BPTTD4D & 340 & 18,17 & 18,25 & ND & 19,49 & ND \\
BPTTD16D & 341 & 12,59 & 30,19 & ND & 42,49 & ND \\
BPTTD32D & 342 & 37,56 & 145,39 & ND & 186,79 & ND \\
\hline BPTSD30M & 352 & & & & & \\
BPTSD2H & 353 & ND & $380.760,06$ & ND & ND & ND \\
BPTSD6H & 354 & ND & $138.249,58$ & ND & ND & ND \\
BPTSD18H & 356 & ND & ND & ND & 143,84 & ND \\
BPTSD24H & 357 & $1.257,37$ & 300,23 & ND & 796,20 & ND \\
BPTSD4D & 358 & 21,80 & 49,08 & ND & 76,63 & ND \\
BPTSD16D & 359 & 2,79 & 15,48 & ND & 62,46 & ND \\
BPTSD32D & 360 & 39,27 & 205,12 & ND & 215,13 & ND \\
\hline BPTAD30M & 370 & & & & & \\
BPTAD2H & 371 & ND & $57.862,12$ & ND & ND & ND \\
BPTAD6H & 372 & ND & $536.212,13$ & ND & ND & ND \\
BPTAD18H & 374 & ND & $494.723,46$ & ND & ND & ND \\
BPTAD24H & 375 & $2.572,65$ & $50.448,88$ & ND & $1.919,23$ & ND \\
BPTAD4D & 376 & 17,67 & 29,18 & ND & 40,68 & ND \\
BPTAD16D & 377 & & & & & \\
BPTAD32D & 378 & 240,00 & 922,59 & ND & $1.174,47$ & ND \\
\hline & & & & &
\end{tabular}

Tabela 28 - Concentrações de xilenos (em $\mathrm{mg} / \mathrm{Kg}$ ) obtidas no ensaio de desorção do contaminante puro pelo argilito coletado na Rua Bom Pastor (amostra BP), na forma de rocha total (T), fração silte (S) e fração argila (A).

\begin{tabular}{ccccccc}
\hline Código & Sequencial & Benzeno & Tolueno & Etilbenzeno & Mp-Xilenos & o-xileno \\
\hline BPXTD30M & 388 & & & & & \\
BPXTD2H & 389 & ND & ND & ND & $729.001,41$ & ND \\
BPXTD6H & 390 & ND & ND & 937,52 & $41.794,83$ & 889,37 \\
BPXTD18H & 392 & ND & ND & ND & $581.908,74$ & ND \\
BPXTD24H & 393 & & & & & \\
BPXTD4D & 394 & ND & ND & ND & $53.141,34$ & ND \\
BPXTD16D & 395 & & & & & \\
BPXTD32D & 396 & ND & ND & ND & $689.612,61$ & ND \\
\hline BPXSD30M & 406 & & & & & \\
BPXSD2H & 407 & ND & ND & ND & $413.438,37$ & ND \\
BPXSD6H & 408 & ND & 202,30 & $3.426,01$ & $145.608,61$ & $2.995,46$ \\
BPXSD18H & 410 & ND & ND & ND & $439.850,46$ & ND \\
BPXSD24H & 411 & & & & & \\
BPXSD4D & 412 & 905,34 & $1.390,84$ & $1.125,94$ & $5.126,68$ & $2.686,08$ \\
BPXSD16D & 413 & ND & ND & ND & $101.722,44$ & ND \\
BPXSD32D & 414 & ND & ND & ND & 901,32 & ND \\
\hline BPXAD30M & 424 & & & & &
\end{tabular}




\begin{tabular}{ccccccc} 
BPXAD2H & 425 & ND & ND & ND & $475.676,03$ & ND \\
BPXAD6H & 426 & ND & ND & $1.312,24$ & $56.061,20$ & $1.120,43$ \\
BPXAD18H & 428 & ND & ND & $5.517,49$ & $211.992,88$ & $4.027,49$ \\
BPXAD24H & 429 & & & & & \\
BPXAD4D & 430 & ND & ND & ND & $15.838,19$ & ND \\
BPXAD16D & 431 & & & & & \\
BPXAD32D & 432 & ND & ND & ND & $504.967,94$ & ND \\
\hline
\end{tabular}

Tabela 29 - Concentrações de BTEX (em mg/Kg) obtidas no ensaio de desorção de gasolina pelo argilito coletado na Av. Juntas Provisórias (amostra JP), na forma de rocha total (T), fração silte (S) e fração argila (A).

\begin{tabular}{|c|c|c|c|c|c|c|}
\hline Código & Sequencial & Benzeno & Tolueno & Etilbenzeno & Mp-Xilenos & O-xileno \\
\hline PGTD30M & 10 & & & & & \\
\hline JPGTD2H & 11 & & & & & \\
\hline JPGTD6H & 12 & ND & $2.551,71$ & $2.485,17$ & $9.872,46$ & $4.256,87$ \\
\hline JPGTD18H & 14 & & & & & \\
\hline JPGTD24H & 15 & $2.548,98$ & $9.546,32$ & $3.943,57$ & $22.473,41$ & $6.616,76$ \\
\hline JPGTD4D & 16 & $1.671,35$ & $8.342,02$ & $4.888,41$ & $24.910,25$ & $9.130,80$ \\
\hline JPGTD16D & 17 & ND & ND & 261,00 & $2.547,58$ & $1.206,34$ \\
\hline JPGTD32D & 18 & 367,34 & $1.354,61$ & ND & $3.228,22$ & ND \\
\hline JPGSD30M & 28 & & & & & \\
\hline JPGSD2H & 29 & ND & $7.525,71$ & ND & ND & ND \\
\hline JPGSD6H & 30 & 177,00 & $3.867,80$ & $2.276,27$ & $11.846,24$ & $5.050,54$ \\
\hline JPGSD18H & 32 & $2.048,88$ & $3.054,21$ & $1.491,97$ & $8.193,60$ & $3.899,33$ \\
\hline JPGSD24H & 33 & $2.720,81$ & $10.767,81$ & $4.409,83$ & $22.382,59$ & $7.800,73$ \\
\hline JPGSD4D & 34 & 789,60 & $6.568,43$ & $3.402,83$ & $17.228,52$ & $6.124,75$ \\
\hline JPGSD16D & 35 & ND & ND & 810,52 & $5.150,17$ & $2.687,22$ \\
\hline JPGSD32D & 36 & 423,30 & $1.380,05$ & ND & $2.815,94$ & ND \\
\hline JPGAD30M & 46 & & & & & \\
\hline JPGAD2H & 47 & & & & & \\
\hline JPGAD6H & 48 & 128,00 & $3.522,21$ & $2.359,70$ & $13.085,59$ & $4.250,34$ \\
\hline JPGAD18H & 50 & 410,37 & $1.384,39$ & $1.080,83$ & $5.679,63$ & $2.838,51$ \\
\hline JPGAD24H & 51 & $4.315,96$ & $13.490,57$ & $5.109,55$ & $25.928,25$ & $8.907,07$ \\
\hline JPGAD4D & 52 & $2.718,11$ & $6.609,01$ & $3.825,24$ & $20.546,78$ & $7.093,00$ \\
\hline JPGAD16D & 53 & ND & ND & 684,86 & $4.605,89$ & $2.477,38$ \\
\hline JPGAD32D & 54 & 69,16 & 227,25 & ND & 869,84 & ND \\
\hline
\end{tabular}

Tabela 30 - Concentrações de benzeno (em $\mathrm{mg} / \mathrm{Kg}$ ) obtidas no ensaio de desorção do contaminante puro pelo argilito coletado na Av. Juntas Provisórias (amostra JP), na forma de rocha total (T), fração silte (S) e fração argila (A).

\begin{tabular}{ccccccc}
\hline Código & Sequencial & Benzeno & Tolueno & Etilbenzeno & Mp-Xilenos & o-xileno \\
\hline JPBTD30M & 64 & & & & & \\
JPBTD2H & 65 & $2.747,63$ & $2.062,31$ & ND & 379,07 & ND \\
JPBTD6H & 66 & ND & 263,90 & ND & 241,43 & ND \\
JPBTD18H & 68 & $166.263,90$ & ND & ND & ND & ND \\
JPBTD24H & 69 & & & & & \\
JPBTD4D & 70 & $286.676,96$ & ND & ND & ND & ND \\
JPBTD16D & 71 & 7,94 & 29,49 & ND & 32,66 & ND \\
JPBTD32D & 72 & 56,52 & 234,56 & ND & 195,38 & ND \\
\hline JPBSD30M & 82 & & & & & \\
JPBSD2H & 83 & $72.914,58$ & ND & ND & ND & ND \\
JPBSD6H & 84 & ND & 672,96 & ND & 189,75 & ND \\
JPBSD18H & 86 & $645.969,86$ & ND & ND & ND & ND
\end{tabular}




\begin{tabular}{ccccccc} 
JPBSD24H & 87 & $7.692,65$ & $1.089,92$ & ND & $2.236,01$ & ND \\
JPBSD4D & 88 & $783.870,78$ & ND & ND & ND & ND \\
JPBSD16D & 89 & 9,80 & 27,11 & ND & 32,58 & ND \\
JPBSD32D & 90 & 47,76 & 204,16 & ND & 179,51 & ND \\
\hline JPBAD30M & 100 & & & & & \\
JPBAD2H & 101 & $37.953,32$ & ND & ND & ND & ND \\
JPBAD6H & 102 & 169,98 & 484,10 & ND & 94,48 & ND \\
JPBAD18H & 104 & $242.020,06$ & ND & ND & ND & ND \\
JPBAD24H & 105 & & & & & \\
JPBAD4D & 106 & $469.781,60$ & ND & ND & ND & ND \\
JPBAD16D & 107 & 9,99 & 17,14 & ND & 15,05 & ND \\
JPBAD32D & 108 & 93,24 & 267,25 & ND & 421,25 & ND \\
\hline
\end{tabular}

Tabela 31 - Concentrações de tolueno (em $\mathrm{mg} / \mathrm{Kg}$ ) obtidas no ensaio de desorção do contaminante puro pelo argilito coletado na Av. Juntas Provisórias (amostra JP), na forma de rocha total (T), fração silte (S) e fração argila (A).

\begin{tabular}{ccccccc}
\hline Código & Sequencial & Benzeno & Tolueno & Etilbenzeno & Mp-Xilenos & o-xileno \\
\hline JPTTD30M & 118 & & & & & \\
JPTTD2H & 119 & ND & $293.839,74$ & ND & ND & ND \\
JPTTD6H & 120 & ND & $139.388,06$ & ND & ND & ND \\
JPTTD18H & 122 & ND & $3.767,51$ & ND & 203,33 & ND \\
JPTTD24H & 123 & & & & & \\
JPTTD4D & 124 & ND & $606.930,69$ & ND & ND & ND \\
JPTTD16D & 125 & 10,15 & 23,19 & ND & 24,37 & ND \\
JPTTD32D & 126 & 57,36 & 228,66 & ND & 202,51 & ND \\
\hline JPTSD30M & 136 & & & & & \\
JPTSD2H & 137 & ND & $45.032,92$ & ND & ND & ND \\
JPTSD6H & 138 & & & & & \\
JPTSD18H & 140 & ND & $1.712,10$ & ND & 128,29 & ND \\
JPTSD24H & 141 & & & & & \\
JPTSD4D & 142 & ND & $148.240,13$ & ND & ND & ND \\
JPTSD16D & 143 & ND & 605,19 & ND & ND & ND \\
JPTSD32D & 144 & 42,15 & 159,84 & ND & 154,21 & ND \\
\hline JPTAD30M & 154 & & & & & \\
JPTAD2H & 155 & ND & $269.119,94$ & ND & ND & ND \\
JPTAD6H & 156 & ND & $220.438,99$ & ND & ND & ND \\
JPTAD18H & 158 & ND & $6.089,47$ & ND & 393,67 & ND \\
JPTAD24H & 159 & & & & & ND \\
JPTAD4D & 160 & ND & $645.691,46$ & ND & ND \\
JPTAD16D & 161 & 24,58 & 239,06 & ND & 129,56 & ND \\
JPTAD32D & 162 & 50,89 & 187,86 & ND & 212,07 & ND \\
\hline
\end{tabular}

Tabela 32 - Concentrações de xilenos (em $\mathrm{mg} / \mathrm{Kg}$ ) obtidas no ensaio de desorção do contaminante puro pelo argilito coletado na Av. Juntas Provisórias (amostra JP), na forma de rocha total (T), fração silte (S) e fração argila (A).

\begin{tabular}{ccccccc}
\hline Código & Sequencial & Benzeno & Tolueno & Etilbenzeno & Mp-Xilenos & o-xileno \\
\hline JPXTD30M & 172 & & & & & \\
JPXTD2H & 173 & ND & ND & ND & $188.524,64$ & ND \\
JPXTD6H & 174 & & & & & \\
JPXTD18H & 176 & ND & ND & ND & $130.098,82$ & ND \\
JPXTD24H & 177 & & & & & \\
JPXTD4D & 178 & ND & ND & ND & $540.026,43$ & ND
\end{tabular}




\begin{tabular}{|c|c|c|c|c|c|c|}
\hline JPXTD16D & 179 & & & & & \\
\hline JPXTD32D & 180 & ND & ND & ND & $57.438,94$ & ND \\
\hline JPXSD30M & 190 & & & & & \\
\hline JPXSD2H & 191 & & & & & \\
\hline JPXSD6H & 192 & ND & ND & $4.946,66$ & $198.878,77$ & $3.792,73$ \\
\hline JPXSD18H & 194 & ND & ND & ND & $534.019,30$ & ND \\
\hline JPXSD24H & 195 & & & & & \\
\hline JPXSD4D & 196 & ND & ND & ND & $938.909,38$ & ND \\
\hline JPXSD16D & 197 & ND & ND & ND & $52.206,86$ & ND \\
\hline JPXSD32D & 198 & ND & ND & ND & $33.861,59$ & ND \\
\hline JPXAD30M & 208 & & & & & \\
\hline JPXAD2H & 209 & ND & $2.412,68$ & ND & $101.124,14$ & ND \\
\hline JPXAD6H & 210 & ND & ND & $12.174,52$ & $558.615,55$ & $10.754,61$ \\
\hline JPXAD18H & 212 & ND & ND & ND & $827.682,75$ & ND \\
\hline JPXAD24H & 213 & & & & & \\
\hline JPXAD4D & 214 & ND & ND & ND & $734.869,12$ & ND \\
\hline JPXAD16D & 215 & & & & & \\
\hline JPXAD32D & 216 & ND & ND & ND & $388.984,32$ & ND \\
\hline
\end{tabular}

Tabela 33 - Concentrações de BTEX (em $\mathrm{mg} / \mathrm{Kg}$ ) obtidas no ensaio de desorção de gasolina pelo argilito coletado na Rua Cavour (amostra CA), na forma de rocha total (T), fração silte (S) e fração argila (A).

\begin{tabular}{ccccccc}
\hline Código & Sequencial & Benzeno & Tolueno & Etilbenzeno & Mp-Xilenos & o-xileno \\
\hline CAGTD30M & 442 & & & & & \\
CAGTD2H & 443 & 525,78 & $4.270,46$ & $1.917,41$ & $9.754,53$ & $3.749,25$ \\
CAGTD6H & 444 & 183,78 & $2.131,82$ & $1.781,61$ & $7.507,99$ & $3.293,46$ \\
CAGTD18H & 446 & 606,20 & 967,15 & 583,61 & $4.428,74$ & $2.575,24$ \\
CAGTD24H & 447 & $2.024,50$ & $9.720,18$ & $4.208,82$ & $25.548,35$ & $7.322,01$ \\
CAGTD4D & 448 & 221,27 & $1.764,21$ & $2.148,04$ & $12.496,38$ & $4.401,95$ \\
CAGTD16D & 449 & ND & ND & ND & 788,40 & 443,94 \\
CAGTD32D & 450 & 813,14 & $1.394,36$ & ND & $1.674,43$ & ND \\
\hline CAGSD30M & 460 & & & & & \\
CAGSD2H & 461 & 606,41 & $3.744,99$ & $1.966,38$ & $8.210,17$ & $3.153,16$ \\
CAGSD6H & 462 & ND & $1.580,20$ & $1.519,14$ & $8.093,60$ & $3.083,89$ \\
CAGSD18H & 464 & & & & & \\
CAGSD24H & 465 & 969,10 & $6.636,82$ & $2.904,09$ & $17.123,25$ & $5.845,53$ \\
CAGSD4D & 466 & 265,08 & 57,49 & $1.861,64$ & $11.047,10$ & $3.985,59$ \\
CAGSD16D & 467 & ND & 581,50 & ND & ND & ND \\
CAGSD32D & 468 & 88,86 & 190,56 & ND & 215,07 & ND \\
\hline CAGAD30M & 478 & & & & & \\
CAGAD2H & 479 & & & & & \\
CAGAD6H & 480 & 212,52 & $3.959,76$ & $2.260,92$ & $12.254,21$ & $5.288,49$ \\
CAGAD18H & 482 & 97,43 & 588,72 & $1.308,43$ & $6.442,57$ & $3.667,55$ \\
CAGAD24H & 483 & $3.677,65$ & $12.388,36$ & $5.106,62$ & $26.284,88$ & $9.110,73$ \\
CAGAD4D & 484 & 412,57 & $7.624,78$ & $4.949,35$ & $26.645,70$ & $10.584,27$ \\
CAGAD16D & 485 & & & & & \\
CAGAD32D & 486 & 38,76 & 126,59 & ND & 775,92 & ND \\
\hline
\end{tabular}

Tabela 34 - Concentrações de benzeno (em $\mathrm{mg} / \mathrm{Kg}$ ) obtidas no ensaio de desorção do contaminante puro pelo argilito coletado na Rua Cavour (amostra CA), na forma de rocha total (T), fração silte (S) e fração argila (A).

\begin{tabular}{ccccccc}
\hline Código & Sequencial & Benzeno & Tolueno & Etilbenzeno & Mp-Xilenos & o-xileno \\
\hline CABTD30M & 496 & & & & & \\
\hline CABTD2H & 497 & $26.317,98$ & ND & ND & ND & ND \\
\hline
\end{tabular}




\begin{tabular}{|c|c|c|c|c|c|c|}
\hline CABTD6H & 498 & 30,09 & 115,49 & ND & 229,39 & ND \\
\hline CABTD18H & 500 & $2.966,32$ & 713,70 & ND & 537,04 & ND \\
\hline CABTD24H & 501 & $1.336,91$ & 292,12 & ND & 907,01 & ND \\
\hline CABTD4D & 502 & 36,27 & 119,78 & ND & 87,95 & ND \\
\hline CABTD16D & 503 & 7,44 & 36,95 & ND & 124,74 & ND \\
\hline CABTD32D & 504 & 68,67 & 373,06 & ND & 413,33 & ND \\
\hline CABSD30M & 514 & & & & & \\
\hline CABSD2H & 515 & 132,64 & 798,29 & ND & 923,50 & ND \\
\hline CABSD6H & 516 & 26,25 & 140,28 & ND & 316,14 & ND \\
\hline CABSD18H & 518 & $153.537,06$ & ND & ND & ND & ND \\
\hline CABSD24H & 519 & & & & & \\
\hline CABSD4D & 520 & 24,74 & 188,58 & ND & 266,91 & ND \\
\hline CABSD16D & 521 & ND & ND & ND & $68.076,57$ & ND \\
\hline CABSD32D & 522 & 36,13 & 197,67 & ND & 179,90 & ND \\
\hline CABAD30M & 532 & & & & & \\
\hline CABAD2H & 533 & $57.130,25$ & ND & ND & ND & ND \\
\hline CABAD6H & 534 & ND & 233,18 & ND & 218,72 & ND \\
\hline CABAD18H & 536 & $271.914,08$ & ND & ND & ND & ND \\
\hline CABAD24H & 537 & & & & & \\
\hline CABAD4D & 538 & 222,12 & 113,60 & ND & 73,74 & ND \\
\hline CABAD16D & 539 & & & & & \\
\hline CABAD32D & 540 & 61,46 & 269,77 & ND & 237,52 & ND \\
\hline
\end{tabular}

Tabela 35 - Concentrações de tolueno (em $\mathrm{mg} / \mathrm{Kg}$ ) obtidas no ensaio de desorção do contaminante puro pelo argilito coletado na Rua Cavour (amostra CA), na forma de rocha total (T), fração silte (S) e fração argila (A).

\begin{tabular}{ccccccc}
\hline Código & Sequencial & Benzeno & Tolueno & Etilbenzeno & Mp-Xilenos & o-xileno \\
\hline CATTD30M & 550 & & & & & \\
CATTD2H & 551 & ND & $103.957,70$ & ND & ND & ND \\
CATTD6H & 552 & & & & & \\
CATTD18H & 554 & ND & 417,59 & ND & 121,78 & ND \\
CATTD24H & 555 & $5.950,37$ & $1.133,71$ & ND & $1.598,00$ & ND \\
CATTD4D & 556 & 15,62 & 13,62 & ND & 16,40 & ND \\
CATTD16D & 557 & & & & & \\
CATTD32D & 558 & & & & & \\
\hline CATSD30M & 568 & & & & & \\
CATSD2H & 569 & ND & $13.534,89$ & ND & ND & ND \\
CATSD6H & 570 & ND & $114.412,81$ & ND & ND & ND \\
CATSD18H & 572 & ND & $2.646,21$ & ND & ND & ND \\
CATSD24H & 573 & $9.587,31$ & 720,13 & ND & $2.012,90$ & ND \\
CATSD4D & 574 & 11,21 & 39,73 & ND & 102,46 & ND \\
CATSD16D & 575 & & & & & \\
CATSD32D & 576 & 36,47 & 150,94 & ND & 173,12 & ND \\
\hline CATAD30M & 586 & & & & & \\
CATAD2H & 587 & ND & $76.398,95$ & ND & ND & ND \\
CATAD6H & 588 & 32,05 & 128,84 & ND & 144,58 & ND \\
CATAD18H & 590 & ND & $10.155,73$ & ND & ND & ND \\
CATAD24H & 591 & & & & & ND \\
CATAD4D & 592 & $110.010,62$ & ND & ND & ND \\
CATAD16D & 593 & & & & & \\
CATAD32D & 594 & 20,43 & 74,23 & ND & \\
\hline
\end{tabular}


Tabela 36 - Concentrações de xilenos (em $\mathrm{mg} / \mathrm{Kg}$ ) obtidas no ensaio de desorção do contaminante puro pelo argilito coletado na Rua Cavour (amostra CA), na forma de rocha total (T), fração silte (S) e fração argila (A).

\begin{tabular}{ccccccc}
\hline Código & Sequencial & Benzeno & Tolueno & Etilbenzeno & Mp-Xilenos & o-xileno \\
\hline CAXTD30M & 604 & & & & & \\
CAXTD2H & 605 & ND & ND & ND & $21.263,63$ & ND \\
CAXTD6H & 606 & ND & ND & ND & $40.017,24$ & ND \\
CAXTD18H & 608 & ND & ND & ND & $389.081,92$ & ND \\
CAXTD24H & 609 & & & & & \\
CAXTD4D & 610 & ND & ND & ND & $11.291,20$ & 423,82 \\
CAXTD16D & 611 & 13,18 & 24,05 & ND & 61,80 & ND \\
CAXTD32D & 612 & ND & ND & ND & $330.703,30$ & ND \\
\hline CAXSD30M & 622 & & & & & \\
CAXSD2H & 623 & ND & ND & ND & $15.344,33$ & ND \\
CAXSD6H & 624 & ND & ND & ND & $25.358,95$ & ND \\
CAXSD18H & 626 & ND & ND & ND & $320.706,91$ & ND \\
CAXSD24H & 627 & & & & & \\
CAXSD4D & 628 & ND & 32,82 & ND & 137,00 & ND \\
CAXSD16D & 629 & 3,55 & 19,18 & ND & 55,35 & ND \\
CAXSD32D & 630 & ND & ND & ND & $391.927,14$ & ND \\
\hline CAXAD30M & 640 & & & & & \\
CAXAD2H & 641 & ND & ND & ND & $40.054,47$ & ND \\
CAXAD6H & 642 & ND & ND & ND & $169.583,78$ & ND \\
CAXAD18H & 644 & ND & ND & ND & $492.357,86$ & ND \\
CAXAD24H & 645 & & & & & \\
CAXAD4D & 646 & ND & ND & ND & $4.888,52$ & ND \\
CAXAD16D & 647 & & & & & \\
CAXAD32D & 648 & ND & ND & ND & 527,16 & ND \\
\hline
\end{tabular}

